

Olladas críticas sobre a paisaxe 
Olladas críticas sobre a paisaxe / Francisco Díaz-Fierros Viqueira, Federico López Silvestre, coordinadores. - Santiago de Compostela : Consello da Cultura Galega, 2009. - 312 p. ; 24 cm. - (Ensaio \& Investigación)

D.L. C 0000 2009. - ISBN 978-84-96530-97-3

1. Paixase-Congresos e asembleas. 2. Paisaxe-Galicia-Historia. I. Díaz-Fierros Viqueira, Francisco, coord. II. López Silvestre, Federico, coord. III. Consello da Cultura Galega

\section{Edita}

(c) CONSELLO DA CULTURA GALEGA, 2009

Pazo de Raxoi $\cdot 2^{0}$ andar $\cdot$ Praza do Obradoiro

15705 - Santiago de Compostela

T $981957202 \cdot$ F 981957205

corre0@consellodacultura.org

www.consellodacultura.org

\section{Tradución e revisión lingǘstica}

Ariarte S.C. (José Fonte Sardiña)

\section{Proxecto gráfico}

Imago Mundi Deseño

\section{Imprime}

$X x x x x$ Xxxxxxx

Depósito Legal: C 00002009

ISBN 978-84-96530-97-3 
FRANCISCO DÍAZ-FIERROS VIQUEIRA FEDERICO LÓPEZ SILVESTRE COORDINADORES

\section{Olladas críticas sobre a paisaxe}

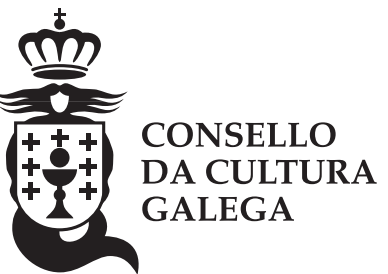


Presentación 


\section{UNS FOROS DE DEBATE PARA CREAR CULTURA E IMAXINAR PAÍS}

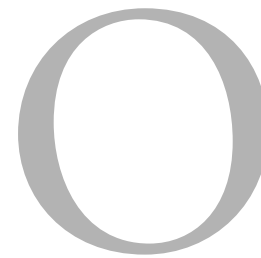

Consello da Cultura Galega aproveitou o seu vinte e cinco aniversario para, ao abeiro do slogan «Crear cultura, imaxinar país», reflexionar e debater. O Consello quixo dar pasos para ampliar a súa posición no marco institucional e no universo de Galicia. Segundo os obxectivos fixados para a actual etapa, pretendeuse a análise e a avaliación da cultura e facela visible cara ao exterior, asumindo o peso da cultura na identidade galega. Esta idea estivo moi presente nos once días de sesións de traballo presencial no salón do Pazo de Raxoi.

O Consello da Cultura Galega conseguiu ser un lugar de encontro, reflexión e diálogo cultural como expresión da pluralidade. Sen dúbida, os obxectivos fixados para as seis actividades de debate cumpríronse nas súas liñas xerais, na opinión dos responsables de cada un dos foros. Quizá por iso os seis debates abertos á análise, ao balance e ás propostas de acción futura no escenario diverso, plural e global marcaron unha liña de traballo que terá continuidade para reforzar o papel da institución na defensa e promoción da cultura galega.

Debemos recordar que os seis foros de debate permitiron analizar aspectos esenciais arredor das seguintes cuestións durante o ano 2008: Galicia na sociedade do coñecemento, os días 3 e 4 de abril; Olladas críticas sobre a paisaxe, os días 8 e 9 de maio; Sociedades plurilingües: da identidade á diversidade, os días 19 e 20 de xuño; Creación artística e identidades culturais, os días 18 e 19 de setembro; $O$ valor critico dos bens culturais, os días 23, 24 e 25 de outubro; e Cultura política: debates contemporáneos, os días 2 e 3 de decembro. Os seus respectivos coordinadores foron Domingo Docampo, Francisco Díaz-Fierros Viqueira, Henrique Monteagudo, María Luísa Sobrino, Iago Seara e Ramón Maiz.

Os foros contaron cunha boa asistencia de público, o que favoreceu o diálogo e o intercambio de ideas. Os medios de comunicación fixéronse eco destes debates, con distintas valoracións e coa publicación ou emisión de diferentes pezas informativas nas que puxeron de manifesto o interese de moitas das pro- 
postas formuladas. Do mesmo xeito, as intervencións de cada foro difundíronse na páxina corporativa do Consello da Cultura Galega, onde seguen estando accesibles para quen queira escoitalas e valoralas.

A esta difusión inicial súmase agora a publicación en libros monográficos de cada foro, que recollen as intervencións presentadas polos participantes. Deste xeito, complétase o programa de difusión das achegas feitas en todos os debates, que constitúen un material útil para todos aqueles que traballan no ámbito da cultura e para todos aqueles que reflexionan sobre os cambios que se están producindo no escenario cultural.

Os datos de participación e a súa repercusión no debate público xustifican, pois, o cumprimento dos obxectivos fixados na programación, que foi posible grazas á colaboración dos directores e secretarios e, sobre todo, ao persoal do Consello da Cultura Galega. O traballo dos técnicos de actividades e de todo o persoal permitiu superar problemas que xurdiron na execución dun programa intenso, no que houbo que coordinar ducias de relatores e retrucantes que chegaron de moi diversos lugares. A todos, en nome do Consello da Cultura Galega, o noso agradecemento por facer posible uns foros de debate que foron especialmente proveitosos para crear cultura e imaxinar país.

\author{
Xosé López García \\ Coordinador xeral dos foros \\ Vicepresidente do CCG
}





\section{Introdución}

Francisco Díaz-Fierros Viqueira 
A paisaxe galega foi un tema central da nosa cultura. Cando menos desde o nacemento do movemento rexionalista, na segunda metade do XIX, e, por suposto, dun xeito insistente e fundamental, desde a Xeración Nós e o Seminario de Estudos Galegos, nos anos da República. Otero Pedrayo foi o gran teórico deste movemento e os seus escritos abondan en rubricar os trazos paisaxísticos da nosa identidade a partir da recreación de escenarios singulares e arquetípicos da nosa peripecia vital como galegos, pero sobre todo sobre a base desa persoal teoría dos tempos da paisaxe. Nela, o tempo cósmico dos nosos penedos vese envolto e arroupado polas cores cambiantes do manto vexetal, que pola súa vez rematan por ser labrados e recreados dun xeito definitivo como paisaxes, polo tempo da historia.

$\mathrm{Na}$ difícil e dolorosa reconstrución do noso ser e sentir como galegos da posguerra, insístese de novo no tema da paisaxe como elemento central da nosa identidade e será no libro editado por Galaxia e coordinado por Ramón Piñeiro en 1955, Paisaxe e Cultura, onde mellor se reflicte esa necesidade. Pero nestes tempos, dous lugueses presentan tamén unha ollada nova sobre as paisaxes galegas: Rof Carballo e Celestino Fernández de la Vega. A súa achega recolle a visión tradicional das paisaxes como unha realidade obxectiva que envolve e condiciona o devir da historia humana e se transforma agora, en boa medida, nunha construción subxectiva: "A paisaxe sen o home é silencio», escribía Celestino no seu maxistral ensaio Abrente e Solpor da Paisaxe, de 1958. Pola súa parte, Rof Carballo, baixo o influxo das teorías psicosomáticas, teorizaba sobre a relación entre as paisaxes e o noso subconsciente.

Nos anos sesenta, sobre todo a partir dos traballos verbo das comarcas galegas dirixidos por Río Barja, introdúcense os temas económicos como un factor máis que considerar entre os elementos que vertebran as paisaxes, pero sen saírse desa ollada tradicional que seguía a contemplalos como algo material e, xa que logo, obxectivo. Este escenario constrúe e, asemade, é reconstruído pola his- 
toria humana. Nesta mesma liña, pero enmarcada nun contexto moito máis amplo de referencias físicas e humanas e cunha utilización exhaustiva dos datos, xorde a Tese de Estado do francés Bouhier, monumento literario que define un antes e un despois da xeografía galega. E así, as paisaxes agrarias que nela se debuxan aínda seguen a ser, na actualidade, a referencia esencial para o estudo do medio rural galego.

Ata o de agora, a análise dos problemas da paisaxe era cousa de artistas, escritores, pintores e, sobre todo cando se precisaba un tratamento teórico, de xeógrafos, é dicir, algo totalmente dependente do mundo da creación ou das ciencias sociais. Pero, andando os anos oitenta, chegan a Galicia os ventos das ciencias ambientais e, con eles, as novas teorías sobre a ecoloxía das paisaxes que introducían os métodos das ciencias naturais nesa vella temática. Desde ese momento, as paisaxes non serán só o froito do encontro e o dialogo da historia coa natureza, e a súa valoración só cuestión de sentimentos e criterios xeográficos. Tamén os mundos da botánica e a xeoloxía terán moito que dicir, sobre todo a partir das estruturas e funcións que se podían identificar nestas novas unidades ecolóxicas.

Xurdiu así, non era para menos, un novo afán por cuantificar, e o que ata daquela se caracterizaba polas descricións máis ou menos persoais, pasou a valorarse coa medida de parámetros obxectivamente definidos. Deste xeito, a escola botánica compostelá, ben enraizada en tradicións científicas que nacen das mans dos traballos de Pourret, Planellas e Merino e acadan a súa madureza no pasado século, cos estudos de Bellot, atopou recentemente na definición das paisaxes galegas a necesaria síntese das súas investigacións sobre taxonomía, socioloxía e ecoloxía vexetal. Así mesmo, a escola dos xeógrafos galegos seguidores do francés Tricart escolleu o estudo das formas do relevo como pedra angular para a definición das paisaxes e para poder construír sobre elas toda unha armazón experimental e teórica, onde o tempo cósmico de Otero atopaba o seu mellor encaixe.

A liña subxectiva de apreciación das paisaxes tampouco foi abandonada nestes tempos que seguiron ao dos epígonos da Xeración Nós, e foron, sobretodo, os escritores paisaxistas como Fole, Manuel María ou Novoneyra, entre outros, os que con máis fervor e continuidade trataron verbo da paisaxe galega. Eles mantiveron acesa a sensibilidade individual e souberon darlles cores e sons 
novos ás vellas terras do Incio, Terra Chá e O Courel. Tamén algúns teóricos, desde a beira da antropoloxía, tentaron penetrar nas escuridades da alma campesiña para desentrañar as referencias que atopaban nela sobre o seu contorno e descubriron que o seu sentir verbo das paisaxes semellaba non ter moito que ver co dos homes e mulleres das vilas e cidades. Finalmente, o gran movemento sobre a estética das paisaxes que xurdira en Francia nos anos setenta, principalmente ao abeiro da escola de París, chegou a Galicia da man da tese de López Silvestre e pechou, dalgún xeito e ata o de agora, a diversidade de olladas verbo da paisaxe que desde os seu albores con Otero Pedrayo foran xurdindo en Galicia.

Esta diversidade de miradas naceu en épocas moi distintas e, xa que logo, a súa traxectoria no tempo foi tamén diferente. Unhas, como as que consideran a paisaxe como unha entidade material, obxecto dos estudos xeográficos e referente para a nosa identidade, teñen máis dun século de vida. Outras, como as que defenden a subxectividade das paisaxes e a súa dependencia fundamental das diferentes olladas e sentimentos que sobre elas se proxectan, apenas levan unhas décadas entre nós. Ambas as dúas, aínda que radicalmente diferentes na súa concepción da paisaxe, teñen en común que os seus practicantes proveñen, na súa meirande parte, do mundo das letras e das artes e, xa que logo, existiría para eles a priori unha base metodolóxica e conceptual común para poder iniciar un diálogo fecundo. En fronte deles, estaría o mundo das ciencias naturais, onde as diferentes prácticas e formas de interpretación das paisaxes mediante métodos nacidos baixo a ilusión da cuantificación crearon unha linguaxe que tiña moi pouco que ver coas interpretacións e pulsións afectivas do grupo anterior. Creo non pecar de pesimista se afirmo que a comunicación entre eses dous grupos de paisaxistas é mínima e que o diálogo interdisciplinario entre eles resulta máis ben un piadoso desexo que unha realidade. Eu diría que o problema da incomunicación entre as dúas culturas, formulado por Snow en 1959, e do que, xa que logo, neste ano conmemoramos o seu cincuenta aniversario, atoparía nos estudos contemporáneos sobre as paisaxes un dos seus máis evidentes exemplos.

Pois ben, o principal obxectivo que nos formulamos cando tivemos que planificar este foro de debate foi, quizais, iniciar un diálogo entre estas dúas culturas paisaxísticas e de aí a diversidade de olladas sobre a paisaxe que aquí se 
congregan. Non podemos pretender que logo destes dous días falemos todos unha linguaxe común e teñamos uns conceptos nidios e perfectamente definidos sobre as paisaxes. Sería pecar de inxenuos. Pero si pensamos que o feito de poder escoitar formulacións diferentes das que estamos afeitos a practicar normalmente poida abrir, devagar, as nosas perspectivas cara a outras realidades e métodos de traballo. Despois de todo, o «ollar» é un ver «dirixido» e «intencionado». E se os nosos ollos están orientados dun xeito preferente nunha determinada dirección e miramos as paisaxes só baixo ese prisma, quizais sexa chegado o momento de que novas perspectivas se abran diante de nós e esa «polifonía das paisaxes», da que falaba Yvan Droz no ano 2005, en La Polyphonie du Paysage, comece a construírse a partir desta iniciativa do Consello da Cultura Galega.

Para rematar, quero facer un apuntamento de urxencia. $\mathrm{O}$ mundo rural galego atópase nun proceso acelerado de reorganización que, na maioría dos casos, consiste nun abandono xeneralizado dos procesos produtivos tradicionais, que lle abre as portas a un monocultivo forestal ou simplemente a unha invasión do inculto. As construcións tradicionais morren de vellas, e as novas érguense cun moi escaso respecto e coidado polas calidades estéticas. Este proceso de destrución do que, probablemente, é máis singular e evocador da paisaxe tradicional galega acontece diante dos nosos ollos e da nosa impasibilidade. Ninguén fai nada para dirixir e reorientar unha tendencia que, en poucos anos, pode rematar cun contorno ao que todos estamos afeitos e que para moitos era a fonte esencial da súa identidade. En consecuencia, entendemos que estas reflexións e diálogos que hoxe inauguramos non son só un exercicio teórico, máis ou menos gratificante, senón que tamén deberían servir para concretar unhas actuacións e políticas urxentes. Por todo iso, saber cara a onde imos, cal é ou cales son a paisaxe ou as paisaxes que desexamos é hoxe unha tarefa inaprazable. E, deste xeito, este foro e calquera outro que se organizase sobre o futuro da paisaxe galega serían sempre, pero sobre todo hoxe, necesarios e benvidos.

En calquera caso, con este foro continuamos unha xeira que hai xa tempo iniciaron os homes da Xeración Nós e do Seminario de Estudos Galegos. Eles pretendían que a cultura galega non perdera un dos seus referentes fundamentais, ensinando como había que ollar esa natureza que probablemente imaxinaron case inmutable. Hoxe, esa realidade muda cunha velocidade vertixinosa e os 
nosos ollos están a contemplar, un chisco desnortados, como todo se desfai. Pero sen dúbidas, o mesmo pulo e parecido alento ao dos nosos predecesores axudaranos na procura dunha solución axeitada para estes problemas, nos que se xoga - diso estou ben certo- o futuro dun dos referentes fundamentais da cultura galega. 
Índice 


\section{PRESENTACIÓN}

10 INTRODUCIÓN

Francisco Díaz-Fierros Viqueira

19 A paisaxe como institución da realidade Augustin Berque

43 O HOME NA PAISAXE. CARA A UNHA FILOSOFÍA INTEGRAL DA PAISAXE DESDE AS HUMANIDADES

45 A paisaxe como institución da estética Raffaele Milani

61 Retruque: A paisaxe. Un concepto etnocéntrico Marcial Gondar Portasany

73 Dinámicas morais e simbólicas da construción da paisaxe José Antonio Fernández de Rota y Monter

93 Retruque: Cara a unha teoría integral da paisaxe Federico López Silvestre

105 DO TERRITORIO Á PAISAXE. ANÁLISE DA PAISAXE DESDE AS CIENCIAS AMBIENTAIS

107 Ecoloxía da paisaxe Francisco Díaz Pineda

121 Retruque: Sobre a paisaxe galega. Reflexións desde a ecoloxía da paisaxe Carlos Vales

$135 \mathrm{O}$ atlas das paisaxes de España Rafael Mata Olmo

175 Retruque: Xénese e ocaso das paisaxes naturais de Galicia Pablo Ramil Rego

185 PASADO E PRESENTE DA PAISAXE. DO DISCURSO DA PAISAXE ÁS PAISAXES SEN DISCURSO

187 Paisaxe e identidade no discurso galeguista Caroline Domingues 
207 Paisaxe e sentido de lugar Joan Nogué

229 Retruque: Paisaxe e sentido de lugar no mundo contemporáneo Jacobo García Álvarez

243 O Porto e o río Douro. A construción dunha nova relación Álvaro Domingues

259 Retruque: Unha reflexión sobre O Porto Julia Fernández de Caleya Blankemeyer

265 Aceptaron as sociedades rurais europeas as políticas paisaxísticas públicas? Pierre Donadieu

285 Retruque: Os comedores da paisaxe Albino Prada Blanco

295 EPÍLOGO

Federico López Silvestre

\section{CURRÍCULOS}


Relatorio

\section{A PAISAXE COMO INSTITUCIÓN DA REALIDADE}

Augustin Berque

EHESS/CNRS, Paris 



\section{FALANDO DA PAISAXE}

Aínda que a humanidade comproba acotío que as traducións non sempre son posibles, os científicos sociais, que teoricamente coñecen a hipótese Sapir-Whorf, adoitan subestimar a incidencia práctica dos problemas lingüísticos nos seus propios obxectos de estudo. A paisaxe é un exemplo disto. Moitas das controversias xurdidas nos últimos anos arredor deste concepto teñen a súa orixe no feito de que as persoas, sinxelamente, non falan da mesma cousa cando debaten sobre a paisaxe. Isto pode acontecer entre xente que se expresa na mesma lingua, así que, con máis razón, ocorre cando as linguas non coinciden. Obviando os falantes que pertencen a ámbitos culturais completamente distintos -como na hipótese Sapir-Whorf-, esta situación é facilmente observable mesmo entre dúas linguas de familias máis próximas, como o inglés e o francés. A palabra landsca$p e$ realmente equivale a paysage? Só en certa forma. Desde o punto de vista lingüístico, a verdade é que estas dúas palabras se formaron dun xeito bastante diferente. Seguindo a regra das linguas xermánicas, en landscape o determinante é land. De feito, no alemán antigo Landschaft - na escrita actual- era orixinariamente unha forma de organización territorial. Non foi ata o Renacemento cando adquiriu o significado dunha representación do territorio, derivado de Landschaftsbild -imaxe da Landschaft. Deste proceso dedúcese que primeiro existe a realidade do territorio: Landschaft, e despois unha representación deste: Landschaft [sbild]. Nas linguas románicas deuse o proceso inverso. Paysage derivaría de pays (terra, país), pero era un neoloxismo acuñado por pintores no século XVI, cuxo significado orixinario era a imaxe en si mesma e non o territorio. Este proceso implica que primeiro se ten a representación e, en segundo lugar, o que se representa, é dicir, o territorio. De feito, só foi máis tarde cando, metonimicamente, paysage veu a significar non só unha imaxe, senón tamén o territorio que se pode pintar ou contemplar. 
Esta cuestión vai máis alá do eido da lexicoloxía. Resulta evidente que, mesmo na actualidade, o tema da paisaxe non é igual na literatura inglesa e na francesa. Aquela mostra unha tendencia a centrarse no obxecto representado, mentres que esta se centra na representación dese obxecto. Un bo exemplo desta diferenza de perspectiva é a distinción entre natural landscape e cultural landscape que popularizaron Carl Sauer e a escola de Berkeley e que é actualmente empregada oficialmente por institucións como a UNESCO. Para moitos estudosos franceses, incluído o autor deste artigo, a devandita distinción é un oxímoro, posto que calquera paisaxe implica a representación -que abrangue a percepción e a concepción- dun territorio determinado e, xa que logo, é necesariamente cultural. Pola mesma razón, supoño, obsérvase na literatura inglesa unha tendencia a «naturalizar» a paisaxe -é dicir, a considerala o territorio mesmo sobre o que se pode falar-, mentres que na literatura francesa se tende a insistir na relatividade cultural da paisaxe. Así, ao longo de todo o monumental estudo de Clarence J. Glacken, Traces on the Rhodian shore (1967), a palabra landscape é empregada no mesmo sentido, o dun ambiente obxectivo e independente das diversas etapas culturais que se sucederon unha tras da outra no mundo occidental desde a Antigüidade e que comportaban actitudes moi diversas cara ao medio natural. Pola contra, a influencia da fenomenoloxía, no tocante á cuestión da paisaxe na literatura francesa, supuxo unha clara distinción entre paisaxe e medio natural, sobre todo a partir dos anos setenta. Lembro unha conversa que mantiven cun colega estadounidense nun simposio celebrado en Quioto en 1992, na que acabei por decatarme de que estabamos a empregar estas dúas palabras cun sentido practicamente oposto. Para el, landscape (paisaxe) significaba unha realidade obxectiva e environment (medio natural) algo necesariamente fenomenolóxico, e para min era todo o contrario.

Fóra de malentendidos, o caso é que no último cuarto de século a historicidade da paisaxe foi moito máis cuestionada no Continente que na Angloesfera. Na historia da arte non é nin moito menos unha novidade que o xénero da pintura paisaxística non existía na Idade Media en Europa: apareceu no Renacemento e foi nomeado posteriormente con palabras que querían dicir "paisaxe» que ou ben non existían ou non tiñan ese sentido na Idade Media. Con todo, non foi ata hai moi pouco cando este feito histórico fixo que nos preguntásemos realmente que é a paisaxe. Ata daquela, a ninguén lle preocupou a evidente 
incompatibilidade entre esta "historicidade fenoménica» - manifesta na arte e na linguaxe- da paisaxe, por unha banda, e, pola outra, a súa "universalidade física» como a forma dunha parte dada do territorio, sendo esta última acepción un trazo importante de disciplinas como a xeografía -particularmente en Alemaña, onde se denomina Landschafskunde, á «ciencia da paisaxe». Esta falta de preocupación reflíctese exemplarmente no estudo de Glacken, que, malia ser un minucioso relato sobre a percepción e consideración da natureza ata os nosos días no mundo occidental, non ten en conta a historicidade do concepto de "paisaxe». Quizais foi Joachim Ritter (Ritter, 1963) o primeiro en considerar esta historicidade como un problema real. A súa tese consistía en que o xurdimento da paisaxe foi unha compensación razoable da obxectivación do medio natural por parte da ciencia moderna; é dicir, mantivo unha unidade cosmolóxica entre o que o dualismo dividira nos dous mundos do subxectivo e do obxectivo. $\mathrm{O}$ certo é que, como xa expliquei noutros traballos (Berque, 2006), esta tese é escandalosamente anacrónica, pero esta non é a cuestión que nos ocupa. Ao Landschaft de Ritter seguíronlle varios traballos que, paseniño, aclararon que a «paisaxe» daquel estudo poida que non fose tal: é unha especie de relación entre a sociedade e o seu medio natural, que na cultura occidental apareceu nun determinado momento da Historia e que non existe en todas as culturas. No seu libro El Paisaje. Genealogía de un concepto, Javier Maderuelo (Maderuelo, 2006) ofrece unha boa síntese deste problema.

Con todo, estes progresos non acabaron coa ambivalencia da palabra "paisaxe». Para as ciencias naturais, como a ecoloxía da paisaxe, segue a ser a forma obxectiva dunha determinada parte da superficie terrestre, teoricamente independente do observador e, xa que logo, non relacionada coa cultura, agás polas consecuencias materiais da antropización. Nas ciencias sociais atopamos toda clase de acepcións, desde a anterior -é dicir, a paisaxe como a forma obxectiva dun ambiente- ata a idea de que a paisaxe é fundamentalmente unha representación construída -«inventada»- social e historicamente. Esta confusión fai que, mesmo entre aqueles que admiten a historicidade de "paisaxe», poucos concorden sobre a súa historia. Moi debatida, por exemplo, é a cuestión de se os romanos tiñan ou non este concepto.

Moitas destas controversias débense á falta de criterios obxectivos para definir o que entendemos por «paisaxe». Pola miña parte, nos últimos vinte anos 
empreguei empiricamente catro, ao principio, e finalmente sete deses criterios. Se non se cumpre ningún destes criterios, coido que falar de "paisaxe» é utilizar mal o termo -polo menos nas ciencias sociais. Estes son, concretamente, os devanditos criterios, dos menos aos máis discriminatorios: 1) Literatura -oral ou escrita-, que canta a beleza dun ambiente. 2) Topónimos en que hai implícita unha valoración visual do ambiente -por exemplo nos franceses Bellevue, Mirabeau, etc. 3) Xardíns do pracer. 4) Arquitectura creada para apreciar as vistas -por exemplo balcóns, balconadas, etc. 5) Representacións pictóricas da paisaxe. 6) Unha ou varias palabras para designar «paisaxe». 7) Reflexións explícitas sobre o tema da paisaxe.

\section{O NACEMENTO DA PAISAXE}

Segundo as condicións anteriores, foi no sur da China, cara ao século V d. de C., cando a paisaxe apareceu por primeira vez na historia da humanidade. A obra de Zong Bing Hua shanshui xu (Introdución á pintura paisaxistica) foi escrita arredor do ano 440. Nela atopamos unha reflexión explícita sobre a natureza da paisaxe -shanshui-, resumida na enunciación dun principio -o de Zong Bing, como eu o chamo- que, como se verá máis adiante, aínda se pode considerar o quid do problema da paisaxe. Zong Bing (375-443) era pintor e a aparición da pintura de paisaxes na China adoita asociarse ás obras do seu contemporáneo, aínda que máis vello ca el, Gu Kaizhi (ca. 346-ca. 406), autor, entre outras cousas, dunha escala en que este xénero se considera menos difícil que pintar persoas e máis que pintar animais, arquitectura e utensilios de uso corrente (Escande, 2005 , p. 80 e ss.). A existencia en si do concepto de "paisaxe» queda testemuñada no ano 353 en Lanting yan ji (Recompilación do banquete no Pavillón das Orquideas), unha antoloxía en que se lembra un suceso ao que volverei no final deste artigo. O devandito testemuño é a palabra shanshui, que aparece no seguinte dístico do célebre calígrafo Wang Xizhi:

散懷山水 San huai shanshui Distraendo o meu pesadume na paisaxe 蕭然忘羈 Xiaoran wang ji Sen decatarme, esquezo o meu cabestro 
ou tamén, de Sun Tong:

地主観山水 Dizhu guan shanshui

仰尋幽人踪 Yang xun you ren zong
O señor da terra observa a paisaxe na procura das pegadas de eremitas ${ }^{1}$

Con todo, a palabra shanshui, que é moito máis antiga, non sempre significou «paisaxe». Derívase de dúas palabras, shan 水, montaña; e shui 山, auga, río; cada unha das cales é, loxicamente, moi antiga. Estas dúas palabras únense por primeira vez nunha, shanshui, contra finais do período dos Estados en Guerra (475-221 a. de C.), pero este novo vocábulo non significa «paisaxe». Máis ben designa os regatos de montaña e é usado principalmente entre os enxeñeiros para falar do control de inundacións e da rega. Non ten nada que ver coa estética. Podémola atopar na poesía de só uns séculos despois, na obra Zhao yinshi shier shou (Doce odas ao convite dun eremita), de Zuo Si (ca. 250-305). No primeiro destes poemas pode lerse o seguinte verso:

山水有清音 Shanshui you qing yin As augas da montaña teñen un son puro²

polo que non é preciso, dise no verso anterior, usar instrumentos musicais. Aquí vese claramente que shanshui fai referencia a un torrente, non á paisaxe. Pero igualmente obvio é que esta palabra adquiriu unha connotación estética e nas décadas seguintes, precisamente pola influencia dos poemas de Zuo Si, o seu significado primario evoluciona á acepción moderna de "paisaxe». Os dísticos recollidos en Lanting, en 353, son froito desta evolución.

Isto non ocorreu en Roma. Malia que sabemos que os romanos apreciaban a beleza do medio natural, non crearon a noción de paisaxe e, por non teren unha palabra para nomeala, non deixaron ningunha reflexión sobre este tema. Ao meu ver, isto é debido a que non relacionaron topia ou topiaria opera, que designan as formas ornamentais de herba cortada dos xardíns ou os motivos paisaxísticos nos frescos - no sentido dado por Vitruvio en De Architectura-; e amoenia, loca amoena ou amoenitas locorum, que designan o grato ou pracenteiro de cer-

\footnotetext{
${ }^{1}$ Estes poemas cítanse en Gotô, 2000, p. 81-82, que tamén é a miña referencia principal para a historia da palabra shanshui.

${ }^{2}$ Pódese ler o poema completo en Gotô, 2000, p. 79-80.
} 
tos lugares no ambiente exterior -en Cicerón, De Oratore. Noutras pala- bras, seguiu existindo unha lagoa entre o territorio e a súa representación, xustamente o que se uniría no Renacemento para dar lugar ao concepto moderno de paisaxe. Esta lagoa mental está simbolizada polo feito de que as villae romanas, aínda que se construísen no medio das paisaxes máis fermosas e con topia nas paredes, permaneceron orientadas cara ao atrium, sen vistas á paisaxe do arredor ${ }^{3}$.

Por este motivo, a coñecida pasaxe seguinte de Cartas, de Plinio fillo: «Regionis forma pulcherrima [...]. Neque enim terras tibi, sed formam aliquam ad eximiam pulchritudinem pictam videberis cernere», non quere dicir que Plinio celebrase a paisaxe como tal, aínda que a maioría dos tradutores empreguen esta palabra. O que escribe, sendo estritos, é que «o aspecto da rexión é marabilloso [...]. Diríase que o que se ve non é unha terra [real], senón unha forma pintada de suma beleza».

A palabra «forma» é demasiado xeral para traducila por "paisaxe». O que se pode deducir da distinción de Plinio entre terra e forma picta é xustamente que as formas da terra, en si mesmas, non están inseridas necesariamente nunha paisaxe. Precísase algo máis: a consciencia de estar gozando da paisaxe en si, é dicir, algo en que as formas da terra e as representacións constitúen unha entidade harmónica para o gozo estético, expresándoo cunha palabra, "paisaxe».

Pola contra, isto é o que se di explicitamente sobre shanshui nos dous exemplos seguintes. $\mathrm{O}$ primeiro son dous versos extraídos dun poema ${ }^{4}$ de Xie Lingyun (385-433), o primeiro "poeta paisaxístico» (shanshui shiren):

情用賞為美 Qing yong shang wei mei Sentir, por medio do gusto, crea a beleza 事昧竟誰辨 Shi meijing shei bian Cousa escura ata que alguén a expresa

o que significa que a beleza dunha paisaxe non reside unicamente nas formas da terra, senón na maneira de contemplalas, o que require certo gusto (shang). Isto, e mais as palabras para expresalo claramente (bian), é o que "fai fermosas» (wei mei) estas formas da terra.

\footnotetext{
${ }^{3}$ Sobre a importancia da arquitectura nestes asuntos, véxase especialmente Maderuelo, 2005.

${ }^{4}$ Cita de Obi, 1983, p. 114-115.
} 
Por suposto, o shang necesario non é universal. Só o posúen uns poucos privilexiados, unha elite equivalente á «clase do lecer» de Veblen. Xa que logo, para apreciar unha paisaxe en si mesma non é preciso labrar a terra, como aclarou Raymond Williams (Willians, 1973). Esta lóxica social é o que eu denomino o «principio de Xie Lingyun». Pero este non é o asunto que nos ocupa. O que realmente importa é que a realidade dunha paisaxe non se limita á materialidade das formas da terra, o que eu chamo o "principio de Zong Bing», xa que nas primeiras liñas da súa Introdución á pintura paisaxística consta claramente o seguinte:

\section{至於山水、質有而趣霊 Zhi yu shanshui, zhi you er qu ling}

Canto á paisaxe, aínda que posúe unha forma material, tende ao espiritual ${ }^{5}$.

E este é o verdadeiro núcleo do problema da paisaxe. Por unha banda, a paisaxe é un obxecto material do exterior e, pola outra, require unha certa predisposición mental por parte do espectador. Ou sexa, a realidade da paisaxe reside na relación entre estes dous polos teóricos. Para captar esta realidade é necesario o que chamarei un "enfoque mesolóxico» da paisaxe.

\section{MESOLOXÍA}

A palabra mésologie (mesoloxía) foi acuñada arredor de 1869 por Louis-Adolphe Bertillon, un médico, estatístico e demógrafo que, segundo se cre, non lle daba o sentido co que Ernst Haeckel definiu a Ökologie (ecoloxía) un pouco antes, en 1867. O significado que lle daba Bertillon era máis amplo, xa que abranguía a vida e a organización das sociedades humanas. Ademais, esta debe ser unha das razóns polas que a palabra "mesoloxía» non prosperou tanto como «ecoloxía» e foi, xa que logo, desaparecendo progresivamente dos dicionarios, malia que foi obxecto dun tratamento detallado na primeira edición do dicionario Grand Larousse du XIX siècle. De feito, o destino da mesoloxía non chegou a cumprirse, que puido ser abarcar os dous ámbitos do que posteriormente sería a socioloxía, por un lado, e a ecoloxía, polo outro. Naquela época, este ámbito de estudo

\footnotetext{
${ }^{5}$ Pódese atopar o texto completo en Delahaye, 1981, p. 84 e ss.
} 
superaba con moito a capacidade dunha soa disciplina. $\mathrm{Na}$ actualidade, malia que mésologie non desapareceu totalmente no francés, as súas acepcións correntes convértena en pouco máis que un sinónimo pouco común -empregado rara vez ou nunca, unha subvariante- de «ecoloxía» e xa non ten ningunha relación coas ciencias sociais.

Desenterrei esta palabra hai vinte anos (Berque, 1986) para traducir o termo fûdogaku 風土学 de Watsuji Tetsurô ${ }^{6}$ (Watsuji, 1935), cuxo significado é o estudo do medio humano -entendendo aquí «medio», en xaponés fûdo 風土, como a relación entre unha sociedade e o seu medio natural. Inspirado por Heidegger, que asemade o fixera en Uexküll (Agamben, 2002), Watsuji estableceu unha distinción decisiva entre ambientes naturais (shizen kankyô 自然環境), obxecto de estudo das ciencias naturais, e medios humanos (fûdo 風土), que, segundo a súa definición, teñen o ser humano como centro e, xa que logo, requiren unha aproximación hermenéutica.

Malia que Watsuji non menciona a Uexküll, a súa distinción entre ambiente e medio é homóloga á que fai o naturalista alemán, precursor da etioloxía, entre Umgebung (os datos obxectivos do ambiente) e Umwelt (o mundo propio dunha determinada especie). Volveremos a esta cuestión posteriormente. Polo de agora, formularemos esta homoloxía como se indica:

\section{Umgebung/Umwelt : kankyô (ambiente)/fûdo (medio).}

Con todo, hai unha diferenza entre ambos os dous pares de palabras: a distinción entre o primeiro par establécese no nivel ontolóxico da biosfera -no espazo- e da evolución -no tempo-, mentres que a distinción entre o segundo par de palabras se establece no tempo correspondente da historia e no espazo da ecúmene, que integra non só os ecosistemas senón, sobre todo, os sistemas técnicos e simbólicos propios do xénero humano: é «medial»ou "mesolóxica», é dicir, eco-tecno-simbólica, mentres que a primeira é só ecolóxica. Por este motivo, igual que a biosfera -que presupón a existencia de vida- é ontoloxicamente superior ao planeta -que é só un sistema físico-químico-, a ecúmene é ontoloxicamente superior á biosfera, que é, por dicilo así, a súa materia prima. No

\footnotetext{
${ }^{6} \mathrm{Na}$ orde habitual xaponesa, e tamén na chinesa, o apelido vai en primeiro lugar.
} 
tocante aos medios humanos -que constitúen conxuntamente a ecúmene-, ao estaren antropizados por sistemas técnicos e humanizados por sistemas simbólicos, non poden quedar reducidos aos ecosistemas do ambiente (Umgebung); son o Umwelt específico do ser humano. É dicir, que lle engaden a cultura á natureza. Da mesma maneira, non poden quedar reducidos á evolución: pertencen especificamente á historia.

A este nivel ontolóxico, historicamente, apareceu e despois desenvolveuse a paisaxe. Dado que para moitos a paisaxe segue a ser, por dicilo así, un Umgebung visible -o que é un oxímoro-, cómpre repetir que, no tocante aos seres humanos, non se pode falar con propiedade de "paisaxe» se non se cumpren os sete criterios dos que falamos anteriormente. Por non dicir que «paisaxe» só existe no léxico dos falantes occidentais de hoxe e non na realidade histórica ou exótica en cuestión.

Neste punto, xorde unha dupla pregunta: que había «antes» do nacemento da paisaxe? E cal é a natureza do seu proceso de nacemento?

A primeira parte é o mesmo que preguntar como se percibe o ambiente nas sociedades «non paisaxísticas». Supoñendo que todas as sociedades humanas posúen un mundo humano como tal (Umwelt), a resposta é que cada unha delas ten a súa forma particular de percibir a realidade dese mundo -isto non debe confundirse cun ambiente universal (Umgebung). Xa que logo, a nosa misión -a das ciencias sociais- consiste en caracterizar o xeito particular de percepción dunha ou doutra sociedade, nesta ou naquela época da historia, por exemplo, analizando o léxico relativo ao ambiente. Evidentemente, existen tantos casos como hai ou houbo culturas na historia da humanidade. Percibir o ambiente como paisaxe é un deles. Noutras palabras, a «paisaxe» é unha variedade, dun proceso máis xeral, específica dun medio dado.

Agora ben, cal é a natureza dese proceso xeral? E como evolucionou a esta variedade, a paisaxe?

\section{COSMOFANÍA}

Hai uns dez anos sentín o impulso de empregar a palabra cosmophanie (Berque, 1998) porque distinguir unicamente entre «civilizacións paisaxísticas» (civilisations paysagères), como a China e a Europa moderna, e «non 
paisaxísticas» (civilisations non-paysagères), do resto do mundo, como fixera ata daquela (Berque, 1995), non era só simplificar de máis, senón que resultaba excesivamente discriminatorio. Non se podía «clasificar» unha civilización por non ter un criterio que só existía na China e na Europa moderna! No entanto, era imposible considerar todos os modos distintos en que as sociedades humanas caracterizaron a súa propia percepción do ambiente. Quedou patente, xa que logo, que se precisaba un concepto xeral que abranguese practicamente calquera dos devanditos modos de percepción. Alén disto, tendo en conta que a base universal de todos estes modos diferentes era a mundanidade humana como tal - Weltlichkeit, na terminoloxía de Heidegger ${ }^{7}$-, é dicir, o feito de ter un mundo - Welt, ou Umwelt, na terminoloxía de Uexküll-, era evidente que todos eles tiñan en común que aparecían (phainein) como a realidade "do mundo" (ho kosmos) particular de cada un. De aquí provén a palabra «cosmofanía».

Por suposto, a expresión concreta -a realidade- da cosmofanía varía en función da cultura e da historia. Podería ser, por exemplo, "paisaxe» ou outra cousa; pero o principio é o mesmo en todos os casos e resulta inherente ao feito de ser unha persoa que vive no planeta Terra.

$\mathrm{O}$ que denominei «un enfoque mesolóxico» ten como finalidade, especificamente, entender que é «realidade» nun medio humano. Neste ámbito, a cosmofanía preséntase como unha cuestión esencial. $\mathrm{Na}$ seguinte parte deste traballo exporei algunhas das claves que, paseniño, provocaron o xurdimento deste problema.

\section{VER COMO}

Un paso importante foi o meu descubrimento da palabra xaponesa mitate 見立 て. Abrir o New Japanese-English Dictionary (5a edición, 2003) pola palabra mitate non é de moita axuda, xa que só se ofrecen as seguintes acepcións: 1. Elección, selección, por exemplo, Quen elixiu esa roupa?; 2. Diagnóstico,

\footnotetext{
7 Para Heidegger, en 1935 (Heidegger, 1949) a pedra é «carente de mundo»-weltlos-, o animal é «pobre en mundo" -weltarm - e o ser humano é "conformador de mundo" -weltbildend-. Desde a perspectiva mesolóxica, isto é o mesmo que diferenciar entre planeta, biosfera e ecúmene -correspondentes, respectivamente, a procesos físicos, evolución e historia.
} 
opinión médica; 3. Valoración, xuízo; 4. Símil, comparación. A última definición derivou nun dos usos do verbo mitateru (facer unha mitate): comparar A con B, co seguinte exemplo: "Comparamos a nosa casa cun castelo cun río detrás que lle serve de foso».

Estas definicións non indican que o concepto de mitate tivese importancia na historia da estética xaponesa e, sobre todo, na dos xardíns e a paisaxe. Isto constateino na extraordinaria obra de Nakamura Yoshio Fûkeigaku nyûmon (Introdución ao estudo da paisaxe) (Nakamura, 1982). Nos xardíns, o principio de mitate consiste en deseñar un motivo que faga referencia a algunha paisaxe coñecida, como o monte Fuji ou as fervenzas de Nachi. Este principio xa se enunciara na introdución do primeiro tratado xaponés sobre a arte dos xardíns no Xapón -e tamén en Asia Oriental-, o Sakuteiki 作庭記, atribuído a Tachibana no Toshitsuna (1028-1094): «Así, farase o xardín ao tempo que se adaptan e harmonizan as formas principais (ohosugata) ás condicións locais de diversos lugares famosos (meisho), os cales un fará algo propio (waga mono)» ${ }^{8}$.

$\mathrm{Si}$, na descrición desta pasaxe non se emprega a palabra mitate -apareceu varios séculos despois-, pero o principio xa queda claro: cómpre orientar o microcosmos -o xardín- cara ao macrocosmos -o territorio-, mediante a referencia a determinados lugares coñecidos pola súa beleza panorámica ou por algunha outra razón histórica.

De feito, este principio non se lles aplica só aos xardíns, senón a calquera forma de creación estética, como son a literatura e a pintura. $\mathrm{O}$ esencial é que a mitate non se restrinxe a un único ámbito, como por exemplo facer referencia a un poema anterior na poesía, trátase, máis ben, de traspasar as fronteiras dese ámbito e facer referencia a outro 9 .

Así, por exemplo, pintar un biombo con referencias a un poema; ou, nun xardín, incluír referencias a outro lugar xeográfico real ou ficticio, tomado da literatura ou da pintura. En definitiva, trátase de relacionar un ámbito A cun ámbito B.

Para unha mellor comprensión do principio de mitate, paga a pena analizar a composición desta palabra. Consta de dous elementos: $m i$ 見, que significa ver, e tate[ru] 立て(る), que quere dicir poñer algo de pé. Polo tanto, analiticamente, ver algo de tal maneira que destaque. Por exemplo, ver un montículo

\footnotetext{
${ }^{8}$ Para máis referencias, véxase Berque, 1986, p. 196 e ss.

${ }^{9}$ Isto non ten moito que ver con ekphrasis, que non é alusivo senón descritivo.
} 
nun xardín como se fose o monte Fuji. Dito doutro xeito, crear o monte Fuji empregando un montículo.

Débese distinguir mitate dun simple sinónimo de «representación». Non é algo puramente icónico, xa que se aprecia mellor cando se cruzan as fronteiras de dous ámbitos sensoriais, como a poesía e a paisaxe. E mesmo nun só ámbito, como a paisaxe, non se basea nunha verosimilitude morfolóxica. Un dos aspectos máis produtivos de mitate a este respecto é a tradición das «oito vistas dos ríos Xiao e Xiang» (Xiao-Xiang bajing 潚湘八景 en chinés, pronunciado Shô-Shô hakkei en xaponés). Esta tradición, que ten a súa orixe no século XI nas obras de Song Di, pintor da dinastía Song do Norte, foi introducida máis tarde no Xapón, onde consistía en ver certos lugares de beleza panorámica «como se» fosen as seis escenas orixinais da China Central -por exemplo «gansos salvaxes pousándose nun banco de area», "veleiros retornando a unha baía afastada», "campá da noite dun templo na néboa», etc. ${ }^{10}$. Moitos lugares do Xapón acabaron por ser vistos deste xeito, como «as oito vistas de Ômi» (Ômi hakkei, no lago Biwa), malia que, en realidade, eran moi diferentes das paisaxes orixinais dos ríos Xiang e Xiao. Por moi diferentes que fosen, e mesmo sendo consciente desa diferenza, o que se valoraba das oito vistas de Ômi era velas «como se» fosen as orixinais.

Queda claro, daquela, que a representación non é o que importa. A mitate non consiste nunha semellanza obxectiva, é o proceso en si de «ver como», que supón unha participación activa do observador na «institución da realidade».

\section{ARTIALIZACIÓN E REALIDADE TANXIBLE}

Nos casos anteriores, mitate encádrase no ámbito da estética. É un xogo estético. Pero, cales son os límites deste xogo?

No sentido máis restrinxido, a estética está relacionada co fermoso. Pero sábese que, en orixe, a palabra grega aisthêsis significaba a facultade de sentir. Foi a partir desta ampla acepción cando Platón falou do mundo tanxible (kosmos aisthêtos), é dicir, a realidade que podemos percibir a través dos sentidos -fronte a to noêton (o intelixible). Isto implica que o eido da estética non é

${ }^{10}$ Para máis referencias, véxase Haga, 1987. 
outra cousa que o eido do sentir (aisthanomai), é dicir, o eido das sensacións e percepcións, que é moito máis extenso que o que adoitamos ter en mente cando falamos sobre a estética.

O problema da paisaxe é que está relacionada tanto coa acepción restrinxida como coa acepción ampla do estético. Diríase que, en xeral, os xeógrafos se ocupan desta mentres que os historiadores da arte e os esteticistas o fan daquela. De feito, os xeógrafos xaponeses non lle puxeron nunca moita atención á cuestión da mitate, que, en cambio, é un tema transcendental para a estética en sentido estrito.

A este respecto, o punto de mira da mesoloxía está enfocado, precisamente, cara á ambigüidade da paisaxe. Na miña experiencia persoal como xeógrafo, descubrir a idea da mitate fíxome repensar progresivamente en toda a cuestión do medio humano e, xa que logo, na da propia realidade. O certo é que, ao principio, o problema parecía limitarse á paisaxe no seu sentido restrinxido -o da historia da arte. Pero, mesmo neste eido, non se podía ignorar que a estética, como rama da filosofía que é, tiña un ámbito de estudo máis amplo, xa que non só se ocupa da beleza da paisaxe como representación -sobre todo na pintura-, senón tamén da propia natureza ou do ambiente, o que, loxicamente, deu lugar ao eido propio da xeografía: a relación das sociedades humanas coa Terra.

No meu caso, esta relación entre a paisaxe como representación -unha obra de arte- e a paisaxe como o que é representado -o ambiente- xurdiu despois de ler a tese de Alain Roger, publicada en 1978 co título Nus et paysages. Essai sur la fonction de l'art. Esta tese xira arredor do concepto de «artialización", é dicir, o efecto da arte na nosa relación coa natureza, que nos fai percibir o ambiente como algo fermoso -efecto in visu- e tamén actúa materialmente sobre este para facelo fermoso -efecto in situ- a través de modelos creados pola arte.

Lin esta tese con especial interese porque, con influencias de La Production de l'espace, de Henri Lefebvre (Lefebvre, 1974), a miña propia investigación sobre o Xapón se convertera nunha busca das relacións analóxicas que vinculan historicamente, nun medio humano, os aspectos mental, social e físico do espazo para conformar una espacialidade específica. Eu xa estaba convencido de que existe un nexo entre a paisaxe in visu e a paisaxe in situ, pero foi na tese de Roger onde atopei unha interpretación filosófica explícita deste asunto, que casaba perfectamente coa miña propia interpretación gradualmente elaborada desa 
mesoloxía que Watsuji defendera; con todo, faltaba aplicala alén dos seus escritos impresionistas e, máis tarde, deterministas sobre fûdo.

\section{MEDIANZA E TRAXECCIÓN}

Fûdo, de Watsuji (Watsuji, 1935), comeza coa seguinte oración: «O obxecto desta obra é explicar fûdosei 風土生 como momento estrutural da existencia humana (ningen sonzai no kôzô keiki 人間存在の構造契機)». Nas versións inglesa e alemá do libro non se traduciu o concepto fûdose ${ }^{11}$. Eu acabei por traducilo polo neoloxismo «medianza» (médiance) ${ }^{12}$ polos dous motivos que expoño a continuación. Primeiro, porque se axustaba á miña tradución de fûdo por milieu en francés -cuxa raíz latina é med, ou meso en grego, de aí: mésologie por fúdogaku. E segundo e principal, porque se axustaba á definición do termo do propio Watsuji. «Momento» (keiki 契機) debe entenderse aquí como unha relación dinámica entre os dous aspectos do ser humano segundo Watsuji ${ }^{13}$ : o

${ }^{11} \mathrm{Na}$ tradución de Geoffrey Bownas, Climate. A philosophical study (1960), que cambiou de título a Climate and culture. A philosophical study en 1988, fûdosei tradúcese indiferentemente por "climate, the function of climate, human climate», etc. ('clima, a función do clima, o clima humano'); na tradución de Dora Fischer-Barnicol e Okochi Ryôgi, Fudo. Der Zusammenhang zwischen Klima und Kultur, de 1992, tradúcese por «Klima, das Klimatische, das Klimatisch Bestimmtsein», etc. ('clima, o climático, a determinación climática'). En ningunha destas dúas traducións se distingue entre fûdo e fûdosei, malia que en xaponés estas dúas palabras son tan distintas como, por exemplo, historia e historicidade ou local e localización en galego. Na versión inglesa, a primeira oración é «My purpose in this study is to clarify the function of climate as a factor within the structure of human existence»; e na alemá é «In der vorliegenden Studie möchten wir zeigen, daß fûdosei, das Klimatische, zur Struktur des menschlichen Dasein gehört». A oración orixinal en xaponés éこの書の目ざすところは人間存在の構造 契機としての風土性を明らかにすることである. Existe unha tradución ao chinés, Feng$t u$, de 2006, que non resulta moi útil, pois os conceptos esenciais de Watsuji adoitan traducirse cos mesmos sinogramas e, por outro lado, o tradutor, Chen Liwei, carece de toda consistencia e coherencia filosóficas. Na devandita tradución, a primeira oración queda reducida a: «Ben shu zhi zai chanming ren de cunzai fangshi yu fengtu de guanxi» ('O obxecto deste libro é explicar as formas en que os seres humanos se relacionan co medio'). Na miña opinión, a mellor tradución dispoñible é a castelá, de Juan Masiá e Anselmo Mataix, Antropología del paisaje. Climas, culturas y religiones (Salamanca, Sígueme, 2006). Eles traduciron fûdosei por «ambientalidad». Con todo, a súa tradución da primeira oración non transmite a definición de Watsuji deste concepto: «El objeto de esta obra es resaltar la importancia de la ambientalidad -clima y paisaje- como elemento estructural de la existencia humana».

12 Que acuñei en 1985 (Berque, 1986).

13 Todos os devanditos tradutores pasaron por alto o concepto de «momento», que tanto lles gustaba aos filósofos xaponeses da época e que tomaron de Hegel, quen, asemade, o tomara da mecánica. 
individuo, por un lado (bito 人), e un conxunto de relacións (chamado aidagara 間柄), polo outro, tanto entre as persoas como entre as persoas e o seu ambiente. Do latín medietas (metade), médiance designa esta relación dinámica entre as nosas dúas «metades» ontolóxicas.

A idea de que o ser humano non se pode reducir a un cogito individual procede en Europa, como mínimo, de Hegel, e xera finalmente o concepto de intersubxectividade. A postura de Watsuji, influenciada polo concepto de Ausser-sich-sein (estar fóra dun mesmo) de Heidegger, forma parte desta tradición. Non obstante, para un xeógrafo coma min, a súa perspectiva hermenéutica non era concluínte. Eu precisaba dunha base más sólida e positivista para converter a medianza no fundamento da mesoloxía. E atopeina na interpretación de Leroi-Gourhan (Leroi-Gourhan, 1964) da aparición da especie humana, segundo a cal os nosos ancestrais simios se tornaron humanos exteriorizando as funcións do «corpo animal» a un «corpo social» constituído por sistemas técnicos e simbólicos. Ao meu ver, este corpo social exteriorizado era a manifestación concreta do absolutamente humano Ausser-sich-sein do Dasein, é dicir, a ex-sistencia humana. Pois ben, dado que os nosos sistemas técnicos e simbólicos forzosamente afectan o ambiente, eu tiña que estender este corpo social -que é tecno-simbólico- para convertelo nun «corpo medial» eco-tecno-simbólico, o que me permitiu definir a medianza como a relación dinámica -o momento- entre as nosas dúas «metades» ontolóxicas: o noso corpo animal e o noso corpo medial, é dicir, o noso medio.

Este momento especificamente humano non se pode producir unicamente a través da exteriorización, segundo afirma Leroi-Gourhan (Leroi-Gourhan, 1964), xa que o resultado apenas sería unha proxección dualista clasicamente moderna do suxeito humano sobre o ambiente como obxecto. A medianza é moito máis que iso. Esta supón non só unha proxección do corpo animal nun medio, senón tamén unha retroproxección dese medio -o corpo medial- no corpo animal. Este movemento de ida e volta é o que eu denomino «traxección» (Berque, 1986).

Máis concretamente, a traxección significa que a nosa corporalidade se proxecta a través dos nosos sistemas técnicos ao medio, que estes antropizan, ao tempo que o noso medio é humanizado polos nosos sistemas simbólicos, é 
dicir, transcende o noso corpo animal na forma de conexións neurais -representacións, etc.-, as cales lle dan sentido e valor. Estas conexións teñen a súa orixe no feito de que os sistemas técnicos proveñen das funcións do mesmo corpo animal. Xa que logo, ao seren exteriorizados -como sistemas de ferramentas, etc.- tamén permanecen "presentes» no interior do corpo animal, onde «representan» o que se exteriorizou -o corpo medial. Correlativamente, o transcendemento do corpo medial ao corpo animal tamén se manifesta en forma de cambios somáticos ${ }^{14}$.

En resumo, como seres humanos, no mesmo proceso de traxección, as técnicas «cosmizan» o noso corpo e convérteno na nosa mundanidade, e os símbolos «somatizan» o noso mundo e convérteno na nosa corporalidade.

Así é como eu entendo a relación entre in visu e in situ na realidade da paisaxe. Igual que a realidade, a paisaxe é traxectiva, é dicir, atópase dentro e fóra de nós e incorpora o suxeito e o obxecto na «traxectividade da realidade».

\section{COSMICIDADE E REALIDADE}

No canto do concepto de Entweltlichung (desmundanización) de Heidegger, prefiro dicir décosmisation (descosmización) para designar o proceso asociado ao dualismo moderno: a división entre un universo exterior e obxectivado, por unha banda, e o mundo interior do suxeito individual moderno, pola outra. De feito, o que se perdeu nesta dicotomía foi xustamente esa unidade do cosmos

\footnotetext{
${ }^{14}$ A curto prazo, esta somatización pode observarse, por exemplo, nos efectos da maxia en moitas sociedades -como causar doenzas ou mesmo a morte. A longo prazo, vén a representar precisamente a tese de Leroi-Gourhan, segundo a cal o corpo dun simio evolucionou ata converterse no do Homo sapiens a través dos efectos de retroalimentación do desenvolvemento de sistemas técnicos e simbólicos. Con todo, e moi contraditoriamente, Leroi-Gourhan só fala dunha exteriorización destes sistemas, quedando así encadrado no dualismo moderno. Esta mesma contradición, aínda que por razóns completamente distintas, atopámola en Heidegger, quen fala, asemade, de "estar fóra dun mesmo» (Ausser-sich-sein), o que vai alén do dualismo moderno, e de "estar cara á morte» (sein zum Tode), o que, como subliñou Watsuji, se limita ao horizonte do suxeito individual moderno. Dito doutro xeito, malia iren alén do paradigma moderno nalgúns aspectos, ambos os dous pensadores quedan enmarcados neste nalgúns outros aspectos. A «medianza» humana fai que o ser humano "estea cara á vida» (sei e no sonzai), como escribiu Watsuji. Mutatis mutandis, esta idea xa está presente no principio de Zong Bing e tamén a expresan simbolicamente a maioría das relixións humanas.
} 
premoderno que foi aseverada ao final do Timeo: «E agora declaremos que o noso discurso sobre o Todo (peri tou Pantos) alcanzou a súa fin. Tras recibir todos os seres vivos, mortais e inmortais, e encherse desta maneira, ser vivente visible (zôon horaton) que comprende todos os seres vivos visibles, imaxe (eikôn) tanxible do deus (theos aisthêtos) intelixible (to noêton), o maior, o mellor, o máis fermoso e perfecto, naceu o Mundo (ho Kosmos): é o Ceo (Ouranos), que é un (heis) e único no seu xénero (monogenês)».

Aínda que Platón establece aquí, asemade, a devandita distinción entre o tanxible e o intelixible, que daría lugar posteriormente ao dualismo moderno, o seu máximo interese, dado que estas liñas constitúen a conclusión da súa ontocosmoloxía máis explícita, cómpre destacar a seguinte identidade: Pan=Kosmos $=$ Ouranos. Noutras palabras: o Todo, o Mundo e o Universo son a mesma cousa.

Con todo, esta unidade practicamente desapareceu en Europa tras a revolución copernicana. Desde aquela, a realidade divídese entre o obxectivo, por un lado, e o subxectivo, polo outro; unha división que mesmo foi medida por Newton en Opticks, en 1704. E a partir de alí, o mundo occidental impuxo progresivamente na Terra este POMC -paradigma occidental moderno-clásico-, onde o obxectivo é o real e o subxectivo, unha ilusión.

Volvendo a Uexküll, esta división equivale a dicir que só o Umgebung é real, mentres que o Umwelt é unha ilusión. De feito, isto é exactamente o que un discípulo de Uexküll, Hidaka (Hidaka, 2003), manifesta cando, no subtítulo dunha obra sobre o Umwelt da bolboreta da col, afirma que «sen ilusión non é posible ver o mundo». Así e todo, esta postura -a do POMC- é contraditoria. $\mathrm{O}$ feito de que a bolboreta vexa os raios ultravioleta e o ser humano non o faga non é unha ilusión subxectiva, senón unha realidade fisiolóxica obxectiva. Xa que logo, a realidade do Umwelt dunha bolboreta non é igual que a dun ser humano malia que ambos os dous habitan o mesmo Umgebung. Posto que os seres vivos só poden vivir se teñen un Umwelt específico, dicir que só o Umgebung é real equivale a afirmar que toda a biosfera está baseada na ilusión, o que, obviamente, resulta absurdo.

É evidente que o POMC resulta ineficaz neste caso. Temos que admitir que existen distintos niveis e diversos tipos de realidade, mesmo no eido das ciencias naturais. E con máis razón se pode dicir isto verbo das culturas humanas, pois 
cada unha delas ten o seu propio mundo malia que están baseadas nun único Umwelt humano, exactamente igual que todos os distintos Umwelten respectivos das especies de seres vivos -incluído o ser humano- están baseados nun único Umgebung -a Terra, ou a biosfera.

O que quero dicir é que, en cada nivel ontolóxico -o da biosfera e o da ecúmene-, na realidade se combina unitariamente unha base universal -un universo- cun mundo particular. É dicir, no tocante á vida -incluída a humana-, a realidade é unha cuestión de cosmicidade. Non é ese obxecto totalmente universal, neutro e exterior que, segundo o POMC, é o único real.

\section{A COSMOFANÍA DA REALIDADE}

Daquela, cal é o proceso que institúe un medio humano específico (Umwelt concreto) baseado no ambiente (Umgebung abstracto)?

Contra finais dos anos oitenta, seguindo unha corrente xeográfica clásica, eu chegara á conclusión de que a realidade dun medio está composta por varias prises médiales (conexións mediais ou potencialidades affordances) que se poden clasificar en catro categorías: recursos, tensións, riscos e servizos. Estas conexións mediais son inherentes ao ser humano, non existen per se como obxectos absolutos. Por exemplo, o petróleo, como combustible, é un recurso, pero para selo foi necesario inventar o vehículo de motor. Xa que logo, as conexións mediais, é dicir, as da paisaxe como servizo, son continxentes e históricas, aínda que comportan necesariamente a existencia dunha base universal e non histórica no ambiente.

Máis tarde, esta cuestión reduciuse á natureza daquilo que, a través das conexións mediais, institúe "como» a realidade dun medio humano. Por exemplo, considerar o petróleo "como" un combustible ou considerar o ambiente "como» unha paisaxe. Ou ben, xa no nivel da biosfera e da evolución, que constitúen a base universal da ecúmene e da historia, considerar unha lonxitude de onda electromagnética de $700 \mathrm{~nm}$ «como» vermella, o que fai o ollo humano, pero non o dunha vaca.

Neste punto comecei a decatarme de que a natureza deste proceso estaba relacionada dalgún xeito co xogo da mitate. Non obstante, eu non dispuña dos 
instrumentos ontolóxicos e antropolóxicos necesarios para desenvolver esta intuición. Descubrinos nos anos seguintes, combinando catro referencias bibliográficas fundamentais: Spiel als Weltsymbol ( $O$ xogo como simbolo do mundo, de Eugen Fink, de 1960; Sein und Zeit (Ser e tempo) e Ursprung des Kunstwerkes ( $A$ orixe da obra de arte), de Martin Heidegger, de 1927 e 1935, respectivamente; Basho (Lugar, 1927), de Nishida Kitarô, de 1927; e Le Geste et la parole (O xesto e a palabra), de André Leroi-Gourhan, de 1964.

$\mathrm{Na}$ obra de Nishida atopei a idea de que o mundo é un predicado (jutsugo 述 語), o que, visto desde a perspectiva xeográfica, significaba para min que é a maneira en que a humanidade interpreta a Terra a través das súas propias conexións mediais, é dicir, os seus sistemas eco-tecno-simbólicos -dito doutro xeito, como sentimos, pensamos e facemos as cousas na Terra. Nas obras de Heidegger e Leroi-Gourhan atopei as claves que me permitiron comprender por fin a definición de medianza de Watsuji, o que me levou a definila como a combinación estrutural dos nosos corpos animal e medial. Por outra banda, Fink axudoume a comprender a continxencia de todo iso: como nun xogo, tanto a ecúmene como a historia poderían ser distintas se tivesen outras regras, ou sexa, outros predicados xurdidos continxentemente -outros mundos-; e este xogo era a «loita» (Streit) entre a Terra e o mundo que Heidegger considera o principio do Ser ou, desde a perspectiva mesolóxica, o inicio da ecúmene como relación entre a Terra e o mundo humano.

Estas ideas, que se materializaron nos noventa, leváronme a elaborar unha teoría da ecúmene (Berque, 2000) que, en liñas xerais, se pode representar coa seguinte fórmula: $\mathrm{R}=\mathrm{S} / \mathrm{P}^{15}$; onde $\mathrm{R}$ é a realidade, $\mathrm{S}$ o suxeito $-\mathrm{o}$ universo, a Terra ou o Umgebung- e P o predicado - un mundo ou Umwelt. Esta fórmula lese así: a realidade é $S$ considerado como P. Dado que isto é moito máis que unha predicación no seu sentido habitual, tamén se pode ler así: a realidade é a cosmofanía de $S$ como P; ou mesmo: a realidade é a traxección de $S$ como $P$.

Seguindo esta lóxica, esta é tamén a esencia da mitate, e da paisaxe en xeral. No caso concreto da mitate, esta significa: ver un ambiente dado $S$-por exemplo a beira do lago Biwa- como se fose unha referencia cultural dada P -por

15 Presentei esta teoría no simposio Shizen to iu bunka no shatei ( $O$ alcance da cultura como natureza), Universidade de Quioto, Departamento de Filosofía, 2 de decembro de 2002; e máis tarde publiqueina (Berque, 2003). 
exemplo un cadro de Song Di. No caso da paisaxe, esta significa: a cosmofanía do ambiente $S$ como unha paisaxe $\mathrm{P}$.

Isto xera a realidade dun medio $\mathrm{S} / \mathrm{P}$ como o noso, que se pode caracterizar polo feito, entre outros, de percibirmos o noso ambiente $S$ como unha paisaxe P. En cambio, se fósemos, por exemplo, kukatja do deserto occidental australiano, percibiriamos o noso ambiente $S$ como unha manifestación do Tjukurrpa P, que os lagartos brancos (kartiya) traduciron por «tempo dos soños» (dreamtime) e que, definitivamente, non é sinónimo de "paisaxe» (Poirier, 1996).

Segundo os testemuños atopados, esta cosmofanía que a "paisaxe» caracteriza apareceu por primeira vez na dinastía Jin oriental, no Pavillón das Orquídeas -Lanting, en Zhejiang, preto da actual Shaoxing-, onde o famoso calígrafo Wang Xizhi reuniu os seus amigos para un banquete o terceiro día do mes lunar de Yonghe IX (353 d. de C.). Como adoitaba acontecer entre a nobreza daquel tempo, isto incluía xogar a un xogo literario chamado «copa que leva a corrente nun regato serpeante» (liu shang qu shui 流觞曲水). Este xogo consistía en escribir un dístico antes de que unha copa de viño, que ía flotando polo regato que atravesaba o xardín, chegase ata onde un estaba. Nalgúns dos poemas que se escribiron nesta ocasión atopamos indicios de que, por vez primeira no que se ía converter no noso mundo, estes distinguidos convidados estaban a «gozar do seu ambiente como unha paisaxe» ${ }^{16}$.

${ }^{16}$ Para máis detalles sobre este banquete, véxase Obi, 1988, p. 113 e ss. 


\section{BIBLIOGRAFÍA}

Agamben, G.: L'Aperto. L'uomo e l'animale, Torino, Bollati Boringhieri, 2002.

Berque, A.: Le Sauvage et l'artifice. Les Japonais devant la nature, Paris, Gallimard, 1986, e Japan. Nature, artifice and Japanese culture, Yelvertoft Manor, Pilkington Press, 1997.

BERQUE, A. (ed.): Actes du colloque franco-japonais sur la recherche paysagère, Tokyo, Maison franco-japonaise, 1987.

BERQUe, A.: Les Raisons du paysage. De la Chine antique aux environnements de synthèse, Paris, Hazan, 1995.

BERQUe, A.: "Cosmophanie ou paysage», en D. GUILlaud et al.: Le Voyage inachevé... À Joël Bonnemaison, Paris, ORSTOM/PRODIG, 1998, p. 741-744.

BERQUe, A.: Écoumène. Introduction à l'étude des milieux humains, Paris, Belin, 2000.

BERQUE, A.: «Shizen to iu bunka (A cultura como natureza)», en E. KIHEI (ed.): Shizen to iu bunka no shatei (O Alcance da cultura como natureza), Kyôto, Kyôto Daigaku daigakuin bungaku kenkyûka, 2003, p. 7-23.

Berque, A.: "Cosmofanía y paisaje moderno", en J. Maderuelo (ed.): Paisaje y pensamiento, Madrid, Abada Editores, 2006, p. 187-207.

BerQUe, A.: El pensamiento paisajero, Madrid, Biblioteca Nueva, 2009.

Delahaye, H.: Les Premières peintures de paysage en Chine, aspects religieux, Paris, École française d'Extrême-orient, 1981.

EsCANDE, Y.: Montagnes et eaux. La culture du shanshui, Paris, Hermann, 2005.

FinK, E.: Spiel als Weltsymbol, Stuttgart, Kohlhammer, 1960.

GLACKEN, C. J.: Traces on the Rhodian shore. Nature and culture in Western thought from Ancient Times to the end of the eighteenth century, Berkeley, Los Angeles, London, University of California Press, 1967. [Hai edición en castelán].

Gotô, A. et al:: Shigo no imêji. Tôshi wo yomu tame ni (As imaxes do léxico poético. Para ler a poesía chinesa), Tokyo, Tôhô Shoten, 2000.

HAGA, T.: «Landscape in cross-cultural perspective: from Hsiao-Hsiang to the Eight Views of Omi», en A. BERQUe (ed.): Actes..., op. cit., p. 115-123.

Heidegger, M.: Sein und Zeit, Tübingen, Niemeyer, 1927. [Hai edición en castelán].

HeidegGer, M.: «Ursprung des Kunstwerkes», Holzwege, Frankfurt/Main, Klostermann, 1949. [Hai edición en castelán].

HIDAKA, T.: Dôbutsu to ningen no sekai ninshiki (Cognición do mundo entre os humanos e os animais), Tokyo, Chikuma, 2003.

KIHEI, E. (ed.): Shizen to iu bunka no shatei (O Alcance da cultura como natureza), Kyôto, Kyôto Daigaku daigakuin bungaku kenkyûka, 2003.

Lefebvre, H.: La Production de l'espace, Paris, Anthropos, 1974.

Leroi-Gourhan, A.: Le Geste et la parole, Paris, Albin Michel, vol. 2, 1964.

Maderuelo, J.: El Paisaje. Genealogía de un concepto, Madrid, Abada Editores, 2005.

Maderuelo, J. (ed.): Paisaje y pensamiento, Madrid, Abada Editores, 2006.

NAKAmURA, Y.: Fûkeigaku nyûmon (Introdución ao estudo da paisaxe), Tokyo, Chuokoron, 1982.

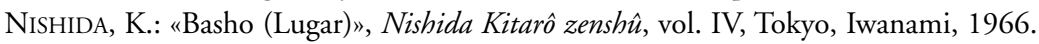

OвI, K.: Sha Reiun. Kodoku no sansui shijin (Xie Lingyun. O poeta paisaxistico solitario), Tokyo, Kyûko shoin, 1983. 
OBI, K.: Chûgoku no inton shisô (O pensamento eremita en China), Tokyo, Chûo kôron, 1988.

POIRIER, S.: Les Jardins du nomade. Cosmologie, territoire et personne dans le désert occidental australien, Münster, LIT Verlag, 1996.

RiTTER, J.: Landschaft. Zur Funktion der Aesthetischen in der modernen Gesellschaft, 1963, na tradución francesa Paysage. Fonction de l'esthétique dans la société moderne, Besançon, les Editions de l'Imprimeur, 1977. [Hai edición en castelán].

Roger, A.: Nus et paysages. Essai sur la fonction de l'art, Paris, Aubier, 1978.

TaChibana No Toshitsuna: Sakuteiki (Notas sobre a arte dos xardíns), Ikeda, Nihon zôen sekkei jimusho Kansai shibu, 1977.

Veblen, T.: Theory of the leisure class, 1899, na tradución francesa Théorie de la classe de loisir, Paris, Gallimard, 1970. [Hai edición en castelán].

VON UeXKÜlL, J.: Streifzüge durch die Umwelten von Tieren und Menschen, Berlin, J. Springer, 1934.

Williams, R.: The Country and the city, Oxford, Oxford University Press, 1973. [Hai edición en castelán]. 


\section{O HOME NA PAISAXE. CARA A UNHA FILOSOFIA INTEGRAL DA PAISAXE DESDE AS HUMANIDADES}



Relatorio

\section{A PAISAXE COMO INSTITUCIÓN DA ESTÉTICA \\ Raffaele Milani \\ Università di Bologna}



Poderiamos comezar cun salaio dicindo, con respecto á desfeita do mundo, como di Jünger, que o espazo perdeu a súa beleza. E logo engadir, encantados polo resplandor da natureza que aínda queda e ao igual que Hugo nas Illuminations, que en vista dos milagres de Deus retráctome do meu razoamento perante a inmensidade. Vacilando entre estes dous estados de ánimo, interrogámonos sobre a elegancia das formas que nos rodean para fascinación dos nosos ollos e estupor da nosa imaxinación. Susto e encanto dominan, sobre todo hoxe en día, a nosa mente.

Tendo en conta estes sentimentos, así como a dramática transformación dos lugares, expresamos unha primeira consideración verbo da arte da paisaxe. Cómpre destacar o feito de que todo aquilo que vén da experiencia estética, todo o que adoitamos cualificar de fermoso, non é algo superficial nin simplemente ornamental, plantado aquí para facer bonito, senón que é substancial para a civilización desde as súas orixes. Porque todo o que está ben edificado, construído, administrado, forxado polo home é tamén, por si mesmo, totalmente fermoso. Ao longo do camiño da historia, que estivo sempre marcado polas traxedias, destacaron os canons de congruencia e incongruencia, de harmonía e desharmonía, de graza e deformación, que non son regras superficiais. Yves Bonnefoy explícanos moi ben no seu libro sobre as terras do interior que Italia -algunhas zonas-, así como outras partes do mundo, que son o resultado dunha ideación que é, asemade, deseño, modelado e escultura daquela terra, reino dos homes que a habitan. A razón da existencia dos lugares patrimonio mundial da UNESCO, motivo central da Convención de Florencia, parte desta mesma unidade de principios antigos e modernos que agrupa comportamentos e ideais. É verdadeiramente desastroso considerar a estética desde un enfoque sentimental para valorizar e defender a paisaxe.

A paisaxe, parte do mundo e da natureza, é unha grande experiencia da emoción, da visión, da contemplación, pero tamén do labor humano tal e como se 
despregou no territorio e no medio. Resultado cultural, non intelectual, porque a natureza, da que isto é revelación no nivel das formas, foi vivida, sentida e modificada polo home ao longo do tempo. Neste proceso converxe un universo de accións, percepcións, representacións, imaxes e conmocións que son tamén a xigantesca obra e o gran relato do home desde a orixe da súa civilización. A partir dunha tupida rede de reflexións sobre a paisaxe como categoría estética, e ao mesmo tempo ética, xorde un panorama de ecos e reenvíos profundísimos. $\mathrm{Na}$ historia das ideas vemos desenvolverse agudas observacións de Kant, Hölderlin, Schiller, Schelling, Hegel. Nun deseño grandioso, pódense recoller boas sintonías entre as diferentes posturas defendidas polo pensamento do século XX: Simmel (1913), Klages (1913), Kerényi (1937), Cassirer (1945), C. Schmitt (1950), M. Schiwnd (1950), E. Strauss (1956), J. Ritter (1963), N. Hartman (1963), Lukács (1963), Adorno (1970) ou Dufrenne (1987). Desde estes aspectos, a paisaxe destaca como o resultado da sensibilidade, a cultura, a historia; é unha obra da arte e da imaxinación.

Esta primeira consideración fainos entender que se pode pensar que as paisaxes, utilizando unha terminoloxía específica da linguaxe filosófica que na actualidade está en desuso, pertencen ás «cousas fermosas» -no sentido material-, igual que un cadro ou un lenzo pintado, un mármore esculpido ou unhas secuencias acústicas de sons e tons, é dicir, igual que as outras artes, e poden selo, como declarou Rosario Assunto, «non só coa mesma consideración das obras de arte, senón tamén sen prexuízo do seu ser natureza: é dicir, obxecto daquel tipo particular de experiencia estética, que finalmente se explica nun xuízo en que o home se deleita -ou sofre gozando- non só coa natureza como obxecto - cousa fermosa no sentido material, ou cousas fermosas, como os espectáculos no escenario-, senón tamén co seu mesmo vivir dentro da natureza sendo parte dela [...]. [O home] devén protagonista, ademais de espectador, do seu ser, asemade obxecto e suxeito daquela realidade, a paisaxe, que para el é motivo de gozo estético» (Assunto, 1994, p. 460-461; e Assunto, 1963).

Segunda consideración sobre a paisaxe como relación. A paisaxe non é só natureza, senón tamén cultura e historia. Como proba diso, a paisaxe é arte da natureza e na natureza. A paisaxe, segundo o pensamento de Assunto, é, en tanto que imaxe, unha forma espiritual que funde visión e creatividade, porque cada mirada -e a mirada é unha relación- crea «unha paisaxe ideal» dentro de 
nós e define en substancia unha categoría tamén mental. Xa os homes da antigüidade, os primitivos, os que nos precederon, souberon transformar a nosa capacidade de ver e sentir partindo dun recoñecemento común: a participación na vida do mundo da que deriva o seu sucesivo significado de proceso psíquico «unificador» da experiencia estética, algo que se produce de inmediato, como acto da visión dos sentidos e como acto do sentimento. Se a examinamos, pois, baixo o punto de vista das formas materiais, a paisaxe, tamén cando a natureza se presenta no seu estado máis salvaxe e inculto, «antes de cada transformación que leva a cabo o enxeño humano, é un descubrimento ao que o home chega mirando a natureza co seu gusto, que é sempre o gusto dunha cultura [...] e cada descubrimento estético das novas paisaxes promove pola súa vez novas mudanzas no gusto e na cultura» (Assunto, 1994, p. 462). Logo é tamén Assunto quen o precisa noutro fragmento de Paesaggio e l'estetica, a denominada paisaxe «natural», pois non é só a representada ou cultivada, senón tamén unha paisaxe producida e plasmada polo home, é a natureza impregnada das formas dunha cultura que gravou as súas propias formas nela, sen destruíla, mais modelándoa. Por iso é considerada lexítima a crítica da paisaxe paralela á crítica da arte. Desde esta perspectiva, que mantén afinidades coas reflexións anteriores de Simmel e Cassirer, o home convértese en artista no momento en que acepta a natureza dentro dun deseño de contemplación e imaxinación, pero tamén antes e máis alá do devandito aspecto do facer, do organizar, do producir e do participar.

Movéndonos entre estas consideracións, podemos observar que o ideal da beleza, no contexto dunha teoría da paisaxe, eleva a paisaxe mesma, polo seu estatuto ético e estético, a ben universal, destacando, deste xeito, unha calidade común a todos os seres; una beleza vivente na que a contemplación transforma o home para que comprenda e sexa comprendido pola natureza. A vida toma, daquela, unha forma que ten en si mesma o seu propio obxectivo e a súa xustificación, na manifestación do infinito prodigarse biolóxico. Só desta maneira podemos acadar a forma infinita da perfección que nos conmove cando contemplamos todo o que é fermoso, como se nós mesmos fósemos infinitos, ao igual que a natureza á que sentimos pertencer. Só nesta epifanía o fermoso e o útil son intercambiables. O labor e o esforzo do home únense ao ideal. Afirmamos e defendemos iso tamén ante a desfeita do mundo, imaxe da que partimos, imaxe 
advertida e declarada en 1943 por Johan Huzinga no parágrafo sobre «o ocaso da paisaxe» contido na obra $A$ desfeita do mundo (Huizinga, 2004, p. 105-109).

O tema da beleza, que inclúe tamén importantes cuestións teolóxicas entre os mitos e as narracións, pódese ler á luz dun complexo manifestarse do humano. No ámbito deste discurso sobre a arte do facer, sobre o finito e o infinito, sobre o ideal reencontrado e renovado, a beleza tense que entender quer como unha beleza apracible, vinculada á contemplación, quer como unha beleza inquietante que vai máis alá da contemplación, experimentando un estado febril que emana do desexo ligado á percepción e á obra. A beleza supón un asomarse continuo e vivo do eu entre as calidades que, por unha división ulterior, se poden chamar relativas á interioridade e á exterioridade. No seu vario despregarse entre a vida da experiencia e a da idea, podemos comprender, por unha parte, o que é fermoso porque está presente na caducidade da existencia real e, por outro lado, o que é fermoso no sentido dunha presunta e sempiterna soberanía do ser. A paisaxe, grazas a iso, é a sede dun intercambio mutable entre o mundo ideal e o mundo empírico, entre categorías mentais e categorías culturais. A paisaxe, por mor do feito de que representa un punto de alta expresión da civilización -artística-, convértese en institución da estética, nun fundamento desta disciplina.

Se fixamos a mirada na cidade moderna, xorde outra imaxe de enorme descomposición. Unha vez máis será a nosa unha ollada angustiada polo intento de defender a natureza embrutecida; unha defensa que, retrospectivamente, chega ata a visión de Ruskin. Fronte á cidade de Prometeo, na que domina o xenio devastador do economicismo, da produtividade e do cientifismo, gustaríanos propoñer o modelo de Anfione, que amansa coa música e o canto a racionalidade do construír. Das miradas posibles sobre a chamada paisaxe urbana ou construída das metrópoles que se estenden infinitamente, rexorden decote, por contraste, esperanzas ou ideais cara a lugares que aínda poden ser símbolos dunha humanización da terra. Nestes últimos anos, outros pensadores e estudosos, ademais dos citados, recolleron a necesidade dunha excelencia da beleza para acceder á verdade do mundo, da vida e da natureza. James Hillman falou do valor e da práctica da beleza natural, e declarou que «se a vida é bioloxicamente estética e se o cosmos en si é primariamente estético, daquela, a beleza non é simplemente un accesorio cultural, unha categoría filosófica, unha parte 
das artes ou mesmo unha prerrogativa do espírito humano. Queda sempre indefinible porque leva un testemuño sensible do que, alén da humana comprensión, é fundamental» (Hillman, 1999, p. 96). Christian Meier (1989), pola súa banda, convidounos a pensar na relación entre a política e a graza na antiga Grecia e incitounos a ver as súas proxeccións na modernidade.

Tras todas estas consideracións, debemos observar que, asemade, a paisaxe, coa súa arte do facer, do representar, do imaxinar, do proxectar, é tamén unha aventura, porque non institúe máis que regras provisionais e mutantes; os canons de visión, aínda que se reelaboren ao longo da historia, viven de superacións continuas. A paisaxe non é unha experiencia de rutina, máis ben está relacionada sobre todo coa capacidade - na arte- de modelar e esculpir o territorio, co estupor da contemplación, coa mobilidade da mirada. A paisaxe non depende dun antes e un despois; é algo incoherente, irregular, que non privilexia un sistema preciso de observación. Ten un compoñente que se pode considerar onírico porque está relacionado coa imaxinación. Ademais, pensando no desenvolvemento da arte moderna e na revolución de época da relación entre arquitectura, urbanismo, transformación dos lugares e das técnicas agrícolas, detectamos unha correspondencia entre a morte da arte e a fin da paisaxe. Tratar da valorización e da tutela do medio natural lévanos inevitablemente a preguntarnos sobre as razóns que ao principio desencadearon este proceso da cultura e da civilización. A estética da paisaxe recolle unha serie de observacións, reflexións, razoamentos, proxectos e obras co propósito de definir un campo de estudo e un plan disciplinar. E faino respondendo a unha revelación das formas, de acordo coa intervención material e inmaterial do home que as fai vivir. Atopamos aquí unha fusión de espírito e materia. Citando a Dufrenne (p. 98-115), poderiamos dicir, por exemplo, que certo ángulo da paisaxe se pode considerar unha obra de arte na medida en que representa unha reflexión sobre a natureza naturans e sobre a natura naturata, porque os lugares son obxectos culturais e asemade naturais, relación de datos obxectivos e creacións do home, en vista tamén dun intercambio entre natural e artificial. O home, imitando a natureza, actúa en calidade de naturante, a través do xenio dela -a natureza-, infundido nos homes: «Aos homes correspóndelles vivir a natureza como mundo, xerando o posible que se ofrece no real». Neste sentido e nesta dirección, que inclúe tamén o gusto e a actividade humana, pódese afirmar que a arte e a categoría estética son aquí correlativas. 
O home modela os territorios cos cultivos, mellora o aspecto dos lugares, ocúpase de facer xardíns, persegue o soño de espazos non contaminados pola súa presenza, proporciona ou inventa imaxes do mundo, elabora un universo de impresións. Ademais, plasma aqueles datos nun sentir necesario, para logo traducilo no recoñecemento das formas e mais na súa evocación, ata elaboralo como participación viva e anulación catártica. Schopenhauer, no tomo de Suplementos a $O$ mundo como vontade e representación (Schopenhauer, 1896), citando o sentimento do sublime, vira a natureza romanticamente e, neste contexto, pódese ver tamén a paisaxe, en relación coa música, para unha función catártica do espírito. Esta é unha visión antiga mais, asemade, moderna.

A analoxía coa música leva a unha terceira consideración, sempre relativa á paisaxe como institución estética que se refire á harmonía.

$\mathrm{Na}$ obra que compón a paisaxe, atopamos a expresión dunha forma de revelación do obxecto que suscita no observador, como se fose un salto repentino alén do contacto directo, a «ilusión» de materializar a íntima realidade do obxecto. Entre a impresión do observador e a expresión do artista -pintor, fotógrafo, cineasta, pero tamén arquitecto, xardineiro ou agrónomo- hai un rexistro de cambios que chega ata a morfoloxía, a descrición xeográfica e a área emotiva. Trátase dun proceso de incorporación e introspección que corresponde a un intercambio entre suxeito e obxecto, entre interioridade e exterioridade. Este procedemento, por unha banda, buscou unhas constantes, unhas normas, unha ansiedade de valores perennes e, pola outra, un impulso cara á aventura, como xa describimos. Dúas forzas que, ao longo dos séculos, plasmaron xuntas o que aínda hoxe chamamos paisaxe. A harmonía e a beleza, conceptos de irradiacións varias, representan o punto de referencia das nosas observacións. A harmonía padece dalgunha maneira o mesmo destino que a beleza, á que está intimamente unida. Ambas as dúas teñen a tendencia a palidecer no moderno vocabulario estético porque implican unha ambigüidade metafísica que rexorde sempre.

Podemos enumerar polo menos tres significados de «harmonía». O primeiro uso pódeselle atribuír a Pitágoras e esténdese durante boa parte do período clásico e medieval. Refírese á división en varias porcións dunha corda en vibración, segundo as relacións aritméticas precisas que producen sons eufónicos en relación co son emitido pola corda que soa internamente. Esta elemental lei da física proxéctase en escala cosmolóxica para que a harmonía se poida entender 
como a relación entre o que existe no mundo terreal e as esferas que forman o universo: A «música das esferas» pódese considerar, xa que logo, en sentido literal, e a harmonía como a relación que se establece entre as esferas e a terra. Trasladada ás obras de arte, a harmonía confirma o canon das relacións cosmolóxicas. Unha estatua harmoniosa non reflicte as formas reais do corpo, senón as súas formas ideais relacionadas coas puramente intelixibles que permanecen agachadas. O defensor principal deste punto de vista é Plotino. O tratado 6 do libro I das Enéadas incorpora todos os elementos esenciais da harmonía metafísica que serán postos en evidencia no ámbito estético. Plotino basea a súa identificación da beleza na semellanza e na comuñón co «un». No parágrafo titulado «O músico elévase intuíndo a harmonía intelixible» (Plotino, I, 3, 20, p. 87), dise que «ten que separar a materia en que se realizan os acordes e as proporcións para intuír a beleza dos acordes en si mesmos, e comprender que as cousas que o encantaban son intelixibles, é dicir, a harmonía intelixible»; non unha beleza particular, senón a beleza da harmonía intelixible. Ademais, terá que utilizar argumentos filosóficos para crer na realidade que "posuía inconscientemente». Noutro punto, trata das harmonías imperceptibles e das harmonías sensibles. Estas últimas están feitas de harmonías imperceptibles. Os sentidos revélanlles as harmonías imperceptibles ás almas que poden intuír a súa beleza, xa que elas manifestan o idéntico no diferente. As harmonías sensibles están «medidas polos números nunha relación subordinada á acción soberana da forma». É dicir, que «imaxes e sombras» baixan sobre as belezas sensibles «na materia, ordenándoa e conmovéndonos co seu aspecto» (Plotino, I, 6, 3, p. 131).

$\mathrm{Na}$ antigüidade clásica e na Idade Media, a relación harmoniosa e a beleza que iso produce son obxectivas. A harmonía do cosmos reflíctese no obxecto. A definición de beleza que se atopa na Summa Theologiae de San Tomé resume esta idea. A beleza, nesta definición, inclúe tres condicións: Integridade ou Prefacio, xa que as cousas que non o son por este mesmo feito son feas; Proporción ou Harmonía; e, por último, Claridade, da cal deriva que lles chamemos fermosas ás cousas que son claras.

O segundo significado de harmonía traslada a atención desde o plano cosmolóxico dos entes ao plano psicolóxico do espectador. Nas formulacións estéticas dos séculos XVII e XVIII e ao longo de toda a época empirista, a harmonía 
sitúase, sobre todo con Shaftesbury e Hutcheson, no interior da teoría da sensibilidade. A beleza, e con ela a harmonía, é substancialmente unha sensación vivida unicamente polo suxeito que persegue «a uniformidade na variedade».

A harmonía atopa un terceiro significado no xogo das facultades. Kant basea a universalidade dos xuízos estéticos non sobre unha harmonía cósmica calquera, senón sobre unha operación común das facultades para xulgar. O feito subxectivo de xulgar o obxecto ou a representación que se dá del precede ao pracer do propio obxecto. Harmonía, neste sentido, non é para nada harmonía das partes do obxecto. Vive e existe nas facultades e no mundo transcendental en que actúan estas facultades.

Hegel enfróntase ao problema da harmonía en diversos puntos das súas Leccións de Estética. Na primeira exposición do concepto de harmonía, que se reflicte nas páxinas dedicadas á música, ofrécese xa unha visión sistemática, que se rexe polas consideracións sobre a beleza en forma abstracta que a contén xunto coa regularidade, a simetría e a conformidade coas leis. A harmonía defínese como «unha relación de diferenzas cualitativas, máis aínda, dunha totalidade destas diferenzas que atopa o seu fundamento na esencia mesma da cousa». Tal relación, nesta perspectiva, emana da conformidade coas leis, xa que a harmonía contén en si o aspecto da regularidade e vai alén da igualdade e da repetición. Ao mesmo tempo, as diferenzas cualitativas non se afirman só como diferenzas no movemento de oposición e contradición, senón tamén como unidade concordante que puxo en evidencia todos os momentos que lle pertencen e que os contén como un todo unido en si mesmo. A harmonía, pois, por unha banda, abrangue a totalidade dos datos esenciais e, pola outra, a súa simple e desagregada oposición, razón pola cal a súa pertenza recíproca e conexión interna se amosan como a súa unidade. Como precisa Hegel, fálase, neste sentido, de harmonías das formas, das cores, dos sons, etc.; por iso a cor azul, a amarela, a verde, a vermella son diferenzas necesarias das cores contidas na esencia mesma da cor. Ao contrario da simetría, aquí non temos só desigualdades que se xuntan con regularidade nunha unidade externa, senón tamén oposicións directas, como as da cor amarela e mais da azul, e a súa neutralización e identidade concreta. A beleza da harmonía das cores consiste na eliminación da diferenza e da oposición, de xeito que se vexa a súa concordancia nas mesmas diferenzas. Perténcense reciprocamente porque a cor non é unilateral, senón unha totalidade 
esencial. A esixencia dunha totalidade leva a dicir que o ollo non ten diante como obxecto só unha cor porque, segundo a tese de Goethe, ve de forma subxectiva tamén a outra cor. Logo Hegel fai unha comparación para explicar este feito. Entre os sons, por exemplo, a súa «tónica», «mediante»e «dominante», son diferenzas esenciais, de tal xeito que, agrupados nun todo único, concordan na súa diferenza. O mesmo, continúa Hegel, acontece tamén coa harmonía das figuras: a súa posición, quietude, movemento, etc.; ningunha diferenza debe presentarse aquí de forma unilateral de por si, xa que de facelo destruiría a concordancia. Entrementres, conclúe Hegel, a harmonía como tal aínda non é a subxectividade e a alma, libres e ideais, porque nestas a unidade é unha pura pertenza recíproca e simple concordancia, senón que falamos de poñer de forma negativa as diferenzas, polo cal o único que se realiza é a súa unidade real. A harmonía non chega a acadar ese ideal. Por exemplo, todas as melodías, aínda que posúan como fundamento a harmonía, teñen en si e expresan unha subxectividade máis alta e máis libre. A simple harmonía, na versión de Hegel, aínda que constitúa o grao máis elevado no tocante á forma abstracta e que estea máis cerca da subxectividade libre, non evidencia nin a animación subxectiva como tal nin a espiritualidade.

A parella melodía-harmonía está sempre en xogo. Novalis, pola súa parte, xa insistira no pasado nas analoxías entre os sentidos e as artes en relación con estes conceptos. Presentara daquela a esixencia da unidade das formas das composicións pictóricas, que está regulada por relacións fixas, como precisamente a unidade da harmonía musical. Ademais, afirmou que a harmonía e a melodía son en conxunto unha única cousa. A melodía é sucesiva; a harmonía, relativa; coa precisión de que a harmonía é a relación entre dous ou máis sons coexistentes.

Esta terceira consideración non é unha digresión, máis ben é unha puntualización do que Schopenhauer bosquexou verbo da analoxía da paisaxe e da natureza coa música, arte en que reina o principio da harmonía. Por harmonía enténdese de feito, no sentido figurado, unha concordancia de sentimentos e pensamentos cun efecto que proporciona unha sensación xeral de paz e serenidade. Esta idea vén do campo da estética, dun universo perceptivo no que se expresa unha complexa consonancia dos signos perceptivos e dos datos obxectivos, unha "conveniencia das partes», unha concordancia de tons. Goethe escri- 
be a Knebele, o 17 de novembro de 1789: «Toda criatura non é outra cousa que un ton, un matiz dunha grande harmonía que ten que estudarse tamén na súa totalidade e amplitude, porque senón cada un dos particulares sería unha letra morta». Con esta integración feliz do particular e o universal, o poeta aclara, nunha rápida síntese, un primeiro significado do termo que está ligado á noción de tonalidade; tonalidade que poderiamos definir como afectiva, específica das categorías mentais nas que os conceptos se funden coas impresións sensoriais e os sentimentos. A harmonía é unha noción fundamental do pensamento e da arte, ferramenta da filosofía e manifestación da vida estética; sitúase entre a realidade e o valor e ten capacidade para ofrecer, mediante a teoría e a experiencia, un campo de coñecementos moi extenso. No tocante á categoría estética, tamén reflicte a harmonía o cambio incesante dos estados das formas e faise medida das relacións que presiden os nosos xuízos no campo da sensibilidade, das técnicas e das prácticas creativas.

Pasando unha vez máis da música ás demais artes, vemos que, na literatura, a harmonía evoca a analoxía, as onomatopeas -exemplos da chamada «harmonía imitativa»-, nunha propagación luminosa evocativa e fonética; nace dunha «musical» proximidade dos acentos e das pausas, da disposición das palabras e das frases capaces de amenizar o discurso nun todo organizado. Na arquitectura, na pintura e nas artes plásticas en xeral conta, con respecto ao todo, porque ordena as partes, unidas de mutuo acordo, a proporción e a boa disposición das figuras. Se quixésemos contar a paisaxe entre o número, agora coxo, das artes contemporáneas, veriamos que a harmonía, xunto coa beleza, ten un papel non determinante. Non obstante, na tradición, a articulación das liñas, dos volumes, das cores, no espectáculo dunha paisaxe compoñen un sistema de datos que se pode ler, coa mirada, segundo os principios da harmonía. Ademais, a harmonía no seu principio primeiro estuda o movemento na relación entre o espazo e o tempo. Hai unha aspiración, no sentimento e no deseño da paisaxe, a non reflectir ou utilizar simplemente as formas reais coas que a natureza se revela, senón as súas formas ideais en relación coas puramente intelixibles que quedan agachadas. A ollada do contemplador é a mirada de quen busca a esencia dos obxectos que temos diante de nós, como o fixeron Durero ou Turner antes de ser pintores. Hai unha música interior na composición daqueles datos que se pode resumir nun deseño de formas ideais. 
Cómpre, pois, facer unha reflexión partindo da analoxía entre música e arquitectura, separando as artes do tempo das do espazo; esta separación non é tan definida como parece. É importante vincular os conceptos de movemento e ritmo co de simetría, e constatar que, no fondo, os dous extremos non están tan lonxe. Isto demóstrano as discusións que poñen o tema da harmonía e da desharmonía, da asonancia e da disonancia, do respecto polas regras e das liberdades do sentimento no marco histórico do sistema das artes liberais e das belas artes, da antigüidade á modernidade. É un percorrido que desde Pitágoras chega ata nós a través de Santo Agostiño e Leibniz. Vitruvio, no seu De Arquitectura -Libro X-, examina o problema das proporcións co exemplo da ringleira de columnas postas á mesma distancia unha da outra; unha análise en que precisamente a simetría intervén á vez que a harmonía. Neste estudo, a harmonía destaca como categoría indiscutible na relación coa proporción real, coa percepción e a función. Este tema, que comprende a medida e o número, o todo e a parte, o cosmos e o corpo humano, aparece nas investigacións sucesivas, ata Alberti -De Re Aedificatoria-, Durero-Da proporción humana- e Palladio-Catro libros de arquitectura-. A evolución dunha estética da harmonía tradúcese nos dilemas das poéticas románticas, para logo disolverse nas do século XX. Tamén a nosa percepción, xunto coas nosas representacións da paisaxe e da natureza, resoa na historia das estratexias dos ollos e dos sentimentos.

Finalmente, existe o xogo dos contrarios. Desde esas consideracións, compréndese a importancia da concepción estética que nos ocupa. Nunha antiga máxima da harmonía pódese detectar unha síntese perfecta de cada razoamento sucesivo, entre o transcorrer da historia e o cambio das tradicións, da admiración da natureza á orde perceptiva e compositiva das varias artes, da fantasía inventiva á percepción. A frase de Filolao (Diels, n.o 32, B 10): "A harmonía nace dos contrarios, porque harmonía é fusión do múltiple e concordia do desacorde», revélanos que o pensamento grego soubo ver a harmonía na discordia, introducindo o tema do control sobre o que é contrario. Facer concordar o que non o é abre o panorama dun tema paradoxal -os romanos utilizarán a expresión concordia discors - e presenta o sistema dos antagonismos no deseño da unificación harmoniosa, dunha unidade orgánica da multiplicidade. A harmonía móstranos, pois, un pensamento do conxunto que triúnfa sobre as discordancias e, desde o punto de vista mitolóxico, marca o final do caos, reafirmando unha 
visión do cosmos. Esta teoría está na base de todos os elementos estéticos, desde a antigüidade ata os inicios do século pasado. Filtrada a través do número e das secuencias, inflúe positiva ou negativamente en moitos exemplos de obras relacionadas co clasicismo, pero tamén, por contraste, en moitas producións das experiencias vangardistas máis recentes. Xa falamos destes aspectos cando citamos brevemente o pensamento de Hegel.

Isto inclúe inevitablemente a revolución estética do 900. Gillo Dorfles, na arte moderna, propuxo unha teoría da desharmonía que é, de feito, histórica e culturalmente afín a ela e que viviu unha imaxinación anticlásica, querendo facer fincapé na forza da sorpresa, da provocación, da distracción, do feo, en contra da idea do equilibrio, da simetría, da serenidade, da beleza e da graza. A importancia dada á disonancia e á casualidade no último século limitou o papel que a harmonía, a beleza, o sublime e a simetría tiveron na historia e nas teorías artísticas. A idea da paisaxe foi arrastrada polas transformacións da idade industrial e postindustrial, do gusto e das artes. O seu «xenio», paixón do observar, do contemplar e do proxectar, ideal do facer e memoria vinculada á cultura, á historia, á ciencia e ao xeito de modelar o territorio, atópase hoxe nun abismo hermenéutico. Na actualidade, a paisaxe como institución da estética caeu no baleiro das mudanzas imprevisibles e escuras. 


\section{BIBLIOGRAFÍA}

Assunto, R.: Il paesaggio e l'estetica, Palermo, Novecento, 1994, p. 460-462.

Assunto, R.: «Introduzione alla critica del paesaggio», De Homine, n. o 5-6, 1963.

BERQUE, A.: Les Raisons du paysage de la Chine antique aux environnements de synthèse, Paris, Hazan, 1995.

CASSIRER, E.: An Essay on Man; edición italiana C. D'Altavilla (ed.): Saggio sull'uomo, Roma, Armando, 1968. [Hai edición en castelán].

ClarK, K.; Landscape into Art, London, John Murray, segunda edición, 1976. [Hai edición en castelán].

CURTIUS, E. R.: Letteratura europea e Medio Evo latino (1948); edición italiana R. ANTONELLI, Italia, La Nuova Firenze, 1952. [Hai edición en castelán].

Dorfles, G.: Elogio della disarmonia, Milano, Garzanti, 1986.

Dufrenne, M.: "L'expérience esthétique de la nature», Revue Internationale de Philosophie, n. ${ }^{\circ}$ 31, p. $98-115$.

Dufrenne, M.: «Le Cap Ferrat», Revue d'Esthétique, n. ${ }^{\circ}$ 16, 1989.

Hartmann, N.: Ästetik, Berlin, 1966; edición italiana M. CACCIARI: Estetica, introdución D. FormagGIO, Padova, Liviana, 1969.

Heidegger, M.: Grundfragen der Philosophie. Ausgewählte "Probleme» der Logik, Friburgo, 1936-1937.

Hillman, J.: La politica della bellezza; edición italiana F. DONFRANCESCO et al., 1999, p. 96.

HuIZINGA, J.: Geschonden wereld; edición italiana L. VILLARI, Lo scempio del mondo, 1948; E. POCAR (trad.), Milano, 2004.

KerÉnYI, K.: "Landschaft und Geist», Apollon und Niobe, München-Wien, Langen-Müller, IV, 1980, p. 80-92.

KLAGES, L.: Mensch und Erde, 1913, Stuttgart, Kröner, 1973; edición italiana L. BONESIO: L'uomo e la terra, Milano, Mimesis, 1999.

MeIER, C.: Politica e grazia, Bologna, Il Mulino, 1989.

RITTER, J.: Landschaft Zur Funktion der Aesthetischen in der modernen Gesellschaft, Munster, Aschendorff, 1963.

Roger, A.: Court traité du paysage, Paris, Gallimard, 1997. En castelán: Madrid, Biblioteca Nueva, 2007.

Schama, S.: Landscape and Memory, London, Fontana Press, 1995.

Sснмiтt, C.: Der nomos der Erde, im Volkerrecht des Jus publicum Europaeum, 1950; edición italiana E. CASTRUCCI e F. VOLPI: Il nomos della terra, Milano, Adelphi, 1991.

Schopenhauer, A.: Die Welt als Wille und Vorstellung, 1819; Ergänzungen, 1844; edición en inglés: The World as Will and Idea, tradutores R. B. HaLDANE e J. KemP, vol. III, London, Kegan, 1896.

SCHWIND, M.: «Sinn und Ausdruck der Landschaft», Studium generale, III, IV e V, 1950.

SIMMEL: Philosophie der Landschaft, 1912-1913; edición italiana "Filosofia del paesaggio», en L. PeRUCCHI (ed.): Il volto e il ritratto. Saggi sull'arte, Bologna, Il Mulino, 1989. [Hai edición en castelán].

STRAUS, E.: Vom Sinn der Sinne. Ein Beitrag zur Grundlegung der Psychologie, Berlin, Springer, 1956. 

Retruque

\section{A PAISAXE. UN CONCEPTO ETNOCENTRICO \\ Marcial Gondar Portasany}

Universidade de Santiago de Compostela 

A miña lectura do exposto polo profesor Milani é que se trata dun magnífico esforzo por construír os eixes fundamentais e básicos do que eu chamaría unha «epistemoloxía da estética da paisaxe».

Resumindo moi esquematicamente a súa posición, diría que, partindo desa dobre experiencia de «encanto e sedución» e "desencanto e frustración» que xorde no espectador diante da paisaxe de hoxe, o profesor fai unha serie de consideracións que constitúen os fundamentos do modelo ao que antes fixen referencia e que se basea nas seguintes ideas forza:

1. A paisaxe non é algo superficial e ornamental, senón que é «natureza».

2. A paisaxe non é só natureza, senón tamén "cultura», «historia» e, mesmo, «aventura», por canto que supón unha continua recreación en que non hai regras predeterminadas.

3. A paisaxe é unha institución estética que ten que ver coa «harmonía», xa se entenda esta ontolóxica, psicolóxica ou loxicamente.

4. No momento actual aparece a teoría da "desharmonía», na que se destacan os valores do «desequilibrio", da "provocación» e do "feo», o que, aplicado á paisaxe, fai que nos atopemos nun baleiro hermenéutico aberto.

Se eu entendo ben este modelo epistemolóxico, suponse que a experiencia da paisaxe é algo que se dá en todas as culturas e en todos os momentos históricos.

Así pois, gustaríame argumentar, precisamente, contra esta pretensión de universalidade do modelo. Quixera deixar claro que a visión que vou defender non debe entenderse como complementaria da do profesor Milani, senón antagónica, por canto unha e outra teñen detrás dous paradigmas, dúas formas de mirar a realidade ou, se se prefire, dúas cosmovisións -a dos mundos urbano e rural- absolutamente incompatibles entre si. O problema de fondo que se discute é se hai posibilidade de traducir a conceptos urbanos a cosmovisión rural 
ou se, cando o facemos, estamos a actuar etnocentricamente, isto é, estamos a impoñerlle unha cosmomovisión que non é a súa. $\mathrm{O}$ que pretendo defender coa miña tese é que, no canto pensar aos outros co noso aparello conceptual, nos preguntemos se non será chegado o momento de revisar as nosas categorías analíticas «cultas», tomando prestadas, para levar a cabo esta revisión, algunhas das claves da cosmovisión non urbana.

Para ir definindo e concretando a miña posición, comezarei por tratar de contestar á pregunta de se o que os urbanitas entendemos por "paisaxe» tamén lles é aplicable ás culturas distintas da nosa e, nomeadamente, aos sectores non urbanos da galega, ou máis ben se trata dun concepto que inadecuadamente lles aplicamos a outros que non comparten o noso universo mental, coa pretensión de asimilalos á nosa maneira de mirar o mundo.

A tese que pretendo defender podería formularse así: os galegos de cosmovisión non urbana -e, en xeral, as culturas campesiñas- están incapacitados para ter experiencia da paisaxe.

Pero hai algo máis: esta imposibilidade non nace das limitacións do mundo campesiño -e das «outras culturas»-, senón da incapacidade do mundo urbano para acceder a unha experiencia integral da relación entre a persoa e o mundo, que, como tantas veces acontece, no canto de recoñecela como unha limitación propia, a proxectamos contra os «outros», como se fosen eles os que tivesen o problema.

Retomo, daquela, a pregunta: están os galegos de cosmovisión non urbana -e as culturas campesiñas en xeral- incapacitados para ter experiencia da paisaxe?

No canto de comezar, como fai o profesor Milani, por un concepto de paisaxe tomado da reflexión dos teóricos da estética, vou principiar polos dicionarios, que son o instrumento do que a clase culta se serve para espallar as súas ideas. Non se trata para nada dunha escolla azarosa. Así como os mapas contribúen a fixar nas mentes de quen os contempla a imaxe dun territorio, e por iso teñen tanta importancia á hora de socializar entre os cidadáns a identidade dun país, ou de calquera tipo de territorio, o mesmo acontece cos dicionarios. As palabras, a través das respectivas definicións, son como mapas mentais que van interiorizando, no que as aprende, o sistema de categorización do mundo que cada lingua comporta. Un dicionario é, pois, un mapa mundi da linguaxe, onde, 
con máis ou menos exhaustividade, podemos atopar a cartografía dos universos mentais e das cosmovisións hexemónicas das xentes que falan esa lingua.

Se ao abeiro desta luz tratamos de descubrir cal é a ideoloxía que se acocha debaixo da semántica da palabra «paisaje» nas distintas edicións do dicionario da Real Academia Española, o primeiro que constatamos é que se trata dun termo que basicamente mantén o mesmo campo semántico ao longo de toda a historia da institución, o que nos permite inferir que se trata dun concepto bastante estabilizado e isto, asemade, indica que os xogos de intereses arredor deste campo se manteñen basicamente estables.

Se tratamos de descubrir as metáforas básicas sobre as que está edificado o significado social da palabra «paisaxe» -os significados eruditos están construídos sobre estas mesmas claves- vemos que nas súas distintas edicións o dicionario está a botar man continuamente de tres imaxes: a da pintura, a da mirada e a da estética.

Paisaxe como pintura: «Pedazo de país en la pintura» (edición de 1832). «Trozo de país más o menos extenso pintado en un cuadro» (edición de 1869). «Pintura o dibujo» (edición de 1927). «Pintura o dibujo que representa cierta extensión de terreno» (edicións de 1992 e 2001).

Paisaxe como mirada: «También se dice de un terreno en el que fijamos la atención» (edición de 1869). "Porción de terreno que se ve desde un sitio» (edición de 1989). «Extensión de terreno que se ve desde un sitio» (edicións de 1992 e 2001).

Paisaxe como experiencia estética: «Terreno en el que fijamos la atención considerándolo artisticamente» (edición de 1869). «Extensión de terreno considerada en su aspecto artístico» (edicións de 1992 e 2001).

A conclusión á que se chega despois deste percorrido cruzado no que se combina a mirada estrutural coa diacrónica é que a idea de paisaxe que estivo a transmitir a Real Academia Española ao longo das distintas edicións do seu dicionario confirma que "paisaje» non é tanto un concepto xeográfico ou ecolóxico, senón unha experiencia, basicamente subxectiva, que se enmarca no ámbito da estética e dos valores artísticos. Pero hai un segundo aspecto que é aínda máis importante, a saber: que esta subxectividade en que se instalan as sucesivas definicións non é a subxectividade da «acción», senón a da mera "contemplación»e do gozo estético, en modo ningún relacionados coa transformación da realidade. 
Tratarei de explicarme. Reducir a paisaxe á contemplación implica ter necesariamente que "externalizala", isto é, converter ese anaco de territorio no que «fixamos a atención», "vemos desde un lugar», convertemos en "cadro» ou "consideramos no seu aspecto artístico» en algo distinto de nós. Por dicilo cunha palabra, implica convertelo nun obxecto, nun ob-iacere, en algo que está fronte a nós e que, polo tanto, é «distinto».

Entre as múltiples consecuencias que ten converter a paisaxe en mirada, ou máis exactamente en marco ou cadro no que se coloca o mirado, neste caso o territorio, está a de mudar a realidade. Como é sabido, xa desde os gregos, a cultura occidental letrada definiu o home como un animal racional -animal en canto que ten a capacidade de sentimento e emotividade, racional porque pode entender. No canto de consideralas en plano de igualdade, a cultura hexemónica sempre seguiu a pensar, na estela de Platón e do seu auriga, que o correcto era que a racionalidade controlase a animalidade, de non ser o caso de poder eliminala -os movementos espiritualistas sempre deveceron por converter o ser humano en «razón pura». Agora ben, a gran meta do imperio da razón foi conseguir que as persoas mirasen toda a complexidade de si mesmas e do mundo no que habitan desde a torre de marfil das ideas.

Isto que dixen presenta un problema engadido. A palabra «idea» deriva de $\epsilon \tilde{\delta} \delta \circ \zeta$, aoristo do verbo $\delta \rho \dot{\alpha} \omega$, que significa ver. «Idea», xa que logo, quere dicir, asemade, «visión» e «concepto». As ideas non son máis que tipos particulares de "visión», pero que comparten a estrutura básica de toda visión, isto é, os humanos só podemos ver cando se dá unha relación entre o fondo e a figura. Quere isto dicir que, para que haxa visión, ten que haber un recorte dunha imaxe sobre un fondo.

No caso desa particular visión que son as ideas, ese recorte é a «definición». Cando eu defino, verbi gratia, a "circunferencia» como "curva, pechada, plana, equidistante», o que estou a facer é recortar esa idea-imaxe do fondo, formado polo conxunto de todas as imaxes. Agora ben, e aquí vén o problema, cando recorto algo sobre un fondo, o que fago é descontextualizar a cousa recortada e, xa que logo, estou a alterar e mistificar o seu significado.

Se quero comprender unha imaxe, supoñamos dun santo, non basta con que me limite a analizala, terei que coñecer se está nun museo, nunha igrexa ou no salón dunha casa, porque segundo o contexto en que estea vai ser unha cousa dis- 
tinta. O mesmo pasa coas ideas, canto máis empeño poño en definilas -non se esqueza que definir, como sinala a propia etimoloxía, é poñer lindeiros, murosmáis me incapacito para contextualizalas e, polo tanto, para entendelas. Non me resisto a dicir, aínda que sexa de pasada, que esa particular paixón polo recorte que implica a definición está mesmo máis exacerbada na carreira pola especialización que hoxe todo o domina e nos leva a querer saber case todo sobre case nada, logrando que as árbores nos deixen sen ver a fraga.

Aplicando isto á cerna da nosa reflexión, a idea de paisaxe concibida como «visión» e como «cadro» está a descontextualizar a paisaxe do resto da realidade pola vía de converter en «anaco» o que é un todo ou, quizais máis exactamente, pola vía de converter en fotografía ou cadro, isto é, en imitación da propia realidade. Estamos na mesma clase lóxica de quen, podendo ter o orixinal, prefire unha fotocopia.

Sabido é que Platón na República divide os membros da polis en tres grupos: os campesiños, que teñen que encargarse da produción de alimentos para que a cidade poida subsistir; os soldados, que han de defendela; e os señores-filósofos, aos que lles corresponde pensala. Cada un destes colectivos ten o seu particular campo de formación e aprendizaxe: os campesiños, a agricultura; os soldados, o campo de batalla; e os filósofos, a escola. A nosa palabra «escola» deriva do

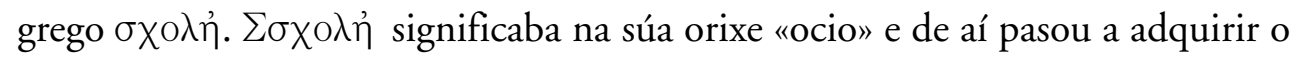
significado de «escola». A razón foi que, para Platón, os filósofos tiñan que estar preocupados unicamente polo saber e este acadábase a través da contemplación e da visión pura, sen ter contacto ningún co mundo dos intereses e das paixóns. Dicían que os que se dedicaban a estas cousas malgastaban a súa vida nos negocios (nec-otium).

Interésame destacar esa conexión entre ocio e visión porque nos dá a clave para concretar as esixencias que leva consigo o concepto que da paisaxe ten a cultura urbana. O perfil de actitudes que Platón lles esixía aos filósofos foi converténdose, paseniño, en cosmovisión da sociedade urbana, no sentido de que a imaxe do señor-filósofo se converte no ideal proclamado - por máis que non sexa levado á práctica- ao que todos os cidadáns deben aspirar. De aí que, se á luz desta filosofía de fondo reconsideramos as calidades que fomos detectando na forma de conceptualizar a paisaxe, veremos que tanto o presuposto do ocio como o da limitación-imaxe-definición, que atopabamos no mundo grego, están aquí de novo. 
As sociedades tradicionais móvense nunha cosmovisión totalmente distinta. O imaxinario do traballo nas sociedades campesiñas está a sobredeterminar o conxunto das actividades da súa vida, o que significa que na súa cosmovisión non hai cabida para o ocio como experiencia positiva.

O imaxinario popular está cheo de advertencias sobre a necesidade de xulgar a xente en relación ao traballo e non á folganza. Permítaseme, para xustificar isto, traer a conto varios exemplos tirados da cultura popular campesiña.

Da multitude de paremias, ditos e cantigas neste sentido, só presentarei unha mínima escolma, cinguíndome ao xénero literario dos refráns: «Nace o home para traballar e non para folgar». "Ao que ten carro e muller, nunca lle falta que facer». «Traballar con tento pero sen perder o alento».

Chegan mesmo a contrapoñerse traballo e saúde, con vantaxe para o primeiro: «O traballar é virtude, o non traballar, saúde. Mellor virtude que saúde».

Con todo, a contradición é só aparente: «O traballo cansa pero non mata».

Tan importante é o triunfo do traballo sobre a preguiza que o refraneiro chega a dicir: "Mellor é traballar de balde que vivir de balde».

E, facendo gala dunha ironía a medio camiño entre Sócrates e a retranca, atopamos este pinchacarneiro dialéctico que obriga a pararse a pensar para poder comprendelo: "Quen fuxe do traballo, fuxe do descanso»; se ben se pensa, parece difícil descansar sen primeiro terse cansado.

Xunto a este conxunto de proposicións en positivo, que exaltan o traballo como forma de estar diante da vida, atopamos tamén unha panoplia de dardos igualmente abundante que persegue o mesmo fin, pero utilizando o camiño de denigrar ao que esta sen facer nada: "Muíño parado non gana maquía». "Mariñeiro que dorme, peixes non colle». «Besta parada non fai xornada». «Camarón que dorme, vaino levando a corrente». "Barco parado non gaña frete». "Quen folga non medra». "Dona que pouco fía sempre fai ruín camisa».

Como se pode comprobar, a filosofía de fondo de todos estes estímulos consiste en ir construíndo e interiorizando nos que comparten esta cosmovisión o sentimento e a convicción de que o ideal de vida para un campesiño consiste en converterse, por parafrasear noutro sentido a expresión heideggeriana, en «seres para o traballo", para os que o tempo de lecer máis que un ideal é un perigo, porque, como di outro refrán, «canto máis un folga, máis preguiza ten». De 
feito, tan lonxe se leva o ataque á ociosidade que ata o imperativo do descanso dominical parece ser vivido máis como unha obriga que como un pracer: «Para descansar, os domingos, e porque o manda Deus».

Alguén puidera pensar, para atacar a miña tese de que os campesiños non pasean, nesas ringleiras de vellos e vellas que, aguilloados pola insistencia do seu médico en que teñen que camiñar, podemos atopar na tarde de calquera día percorrendo os rueiros das nosas aldeas. Contestaría brevemente dicindo que tales vellos non "pasean» senón que «andan». Lonxe deles ese «andar sin otro fin que el de recrearse», que a Real Academia Española esixe para falar de paseo. Só con estar atentos ao tipo de conversas que normalmente teñen entre eles nesas camiñadas poderase percibir que o tema dominante de conversa, cunha monotonía que aburre, é a saúde, a influencia que tales «paseatas» teñen no colesterol ou na hipertensión en función das analíticas que cada quen exhibe, etc. En fin, que non camiñan para encher o tempo de lecer, senón como se tomasen unha menciña, para cumprir co traballo de estar sans ou, máis ben, de tentar recuperar un chisco a saúde perdida. Á vista do dito, teremos que concluír que a experiencia urbana da paisaxe non só está fóra, senón que é antagónica da cosmovisión tradicional da sociedade campesiña galega.

Pero, ademais do traballo que o invade todo sen deixar un momento para o lecer e para a pura contemplación, outro aspecto en que as sociedades campesiñas están nas antípodas da cultura urbana é que, para elas, a totalidade -e non a parte- é o preconcepto desde onde se mira todo.

Os urbanitas estamos moi afeitos a clasificar o tempo en dúas clases: tempo de lecer e tempo de traballo, perfectamente definidos e cuantificados cada un deles. E así, cando estamos no tempo de traballo, o que se agarda de nós e que cumpramos coa actividade produtiva que estamos a facer, sen que teñamos que sentir por iso o máis mínimo pracer -máis ben ao revés-, pero cando, pola contra, estamos no tempo de lecer, sexa unha fin de semana, un festivo ou unha feira, parece que, dalgún xeito, temos a obriga de divertirnos, pasalo ben e «recrearnos», por máis que non sintamos unha especial necesidade. Descansar e producir, otium e nec-otium - de onde procede a nosa palabra «negocio»-, naturalmente que en distintas cantidades, marcarán ata a xubilación o ritmo das nosas vidas.

$\mathrm{Na}$ aldea as cousas son moi doutra maneira. O descanso e, sobre todo, o lecer e a diversión non están, en absoluto, expulsados do mundo do traballo. Fronte 
a esa nidia separación entre tempo de traballo e tempo de festa que caracteriza o mundo urbano, o típico nas aldeas era que os traballos, especialmente os máis esforzados e duros do ano, estivesen impregnados dun aire de festa no que non faltaban os xogos, os cantos, os bailes, a comida extraordinaria e ata os desafíos en verso entre os participantes, sobre todo entre mozos e mozas. Nas mallas, pero tamén nas botas, nas seituras, nos carretos e en toda a serie de traballos, ás veces esgotadores, nos que os veciños colaboraban uns cos outros para paliar o déficit de man de obra familiar e, no fondo, a imposibilidade económica de boa parte das familias para recorrer ao traballo asalariado, había unha chea de actividades e condutas festivas e lúdicas que, ao tempo que estimulaban o traballo, convertían en atractivo e desexado un acto duro e fatigoso.

No caso das mallas, por exemplo, como era normal que no contorno se celebrasen varias ao mesmo tempo, establecíase unha retesía entre os traballadores dos distintos grupos, de xeito que os primeiros que remataban de facer o palleiro o celebraban con foguetes e ata con bombas de palenque. Por suposto que chufaban desta vitoria con bromas e chanzas ata a próxima malla, co conseguinte cabreo dos grupos que quedaran atrasados. Como se pode ver, a broma e o xogo cumprían, asemade, varias funcións: estimular a competitividade no ritmo de traballo, converter un traballo especialmente duro como este en algo apetecible e, ao mesmo tempo, crear ese cemento social que, como Durkheim sinalaba, é o que converte os meros grupos de asociados en comunidades.

Como conclusión, quixera facer a seguinte reflexión. O que a primeira vista parece unha eiva da cultura tradicional, habería que velo como unha fortaleza da que os urbanitas podemos aprender. A única condición que se require é estar dispostos a superar o endémico etnocentrismo de «alta cultura» que nos caracteriza e ser quen de entender que os «outros» tamén nos poden aprender cousas. O que queda da cosmovisión tradicional campesiña, pálido reflexo do que un día non moi afastado foi, conserva aínda potencialidades que poden servir de modelo de como reorientar este noso mundo urbano que, seducido por un falso progreso, camiña cara á súa descomposición. Ideas como a inclusión da diversión no traballo, a superación da psicose do especialismo, a comuñón entre ser humano e natureza, etc., cando se está disposto a pensar desde elas o mundo actual, permiten albiscar que un novo ecoloxismo de rostro máis humano é posible, que cabe substituír o concepto urbano de paisaxe polo de territorio humani- 
zado e que a tradicional separación entre «nós» e os «outros» pode atopar o punto de encontro nun «nos-outros». Nese momento, o respecto polos demais e pola natureza deixará de ser unha utopía.

Se somos quen de facer este esforzo de someter á crítica os nosos alicerces conceptuais, estaremos a iniciar o camiño dunha nova «Ilustración», na que a fragmentación lle deixe paso á totalidade, na que suxeitos, culturas e natureza non se vexan como reinos de taifas e descubran a íntima interdependencia de todas as dimensións da realidade, tal e como xa reclamaba o Discours préliminaire da Enciclopédie, por máis que esta pretensión nunca pasara dos discursos programáticos. 

Relatorio

\section{DINÁMICAS MORAIS E SIMBOLICAS, DA CONSTRUCIÓN DA PAISAXE}

José A. Fernández de Rota y Monter Universidade da Coruña 

Enfoco o presente ensaio dentro do marco dunha Antropoloxía da paisaxe. Trato de descubrir como é que a Antropoloxía pode contribuír ao estudo da paisaxe. Non contesto cunha resposta sinxela -que define e acouta- senón cun rumbo dinámico, que non pecha o concepto, senón que suxire, orienta e insinúa. É este carácter dinámico dos dous conceptos fundamentais da pregunta o que necesariamente me leva a responder deste xeito. Por unha banda, a Antropoloxía é unha canle sinuosa que invade territorios veciños e trata de afirmarse neles. Se a Antropoloxía é unha canle dificilmente definible, a paisaxe é un slippery concept, como tantos conceptos de longa historia, é un concepto esvaradío.

Tense estudado e polemizado sobre cando se utilizou por primeira vez esta palabra - paisaxe- a partir dunha coidada revisión documental. Algúns coinciden en dicir que foi no ano 1462 cando un primeiro texto holandés empregou un termo traducible pola nosa palabra paisaxe. Anos despois, aparecerá noutros países e idiomas europeos. Aínda que sen dúbida resulta interesante descubrir a utilización precisa desta palabra, a realidade é que moito antes había un conxunto de conceptos que se podían relacionar con ela, todo un campo semántico que se movía nun marco de connotacións semellantes. Máis aínda, a vivencia de algo que nós denominariamos "paisaxe» é un continuo na literatura clásica: as descricións do mar de Homero, as súas espantosas tempestades e as praias pracenteiras onde desembarcaban os náufragos parecen suxerir o deleite producido pola contemplación da natureza, e o mesmo poderiamos dicir dos textos de Virxilio e de tantos outros autores clásicos.

É certo que o Renacemento supuxo unha nova maneira de atender e de interesarse pola paisaxe, dentro da que vai cristalizar o termo e a historia dun novo concepto. Pero xa un século antes de aparecer, hai quen atopa unha primeira explicación do xeito de concibir a paisaxe dos renacentistas nunha carta de Petrarca de 1336. O desenvolvemento paisaxístico do Renacemento, tanto na 
literatura como na pintura, converte a contemplación estética da natureza, o deleite sensorial diante do mundo que nos rodea, nun protagonista de excepción no eido cultural das elites. É o comezo dunha trepidante historia estética, técnica e teórica que vai abrir, séculos despois, novos escenarios para a representación e o gozo da paisaxe.

Son moitas as disciplinas que utilizaron a palabra paisaxe, e entre elas está a Antropoloxía, aínda que o fixo relativamente tarde. Nun primeiro momento, o espazo nas monografías etnográficas tradicionais era representado en formas de organización do territorio, distribuído entre clans ou castes, sistemas de propiedade e herdanza da terra, ou a descrición do medio natural, as súas características orográficas, botánicas, zoolóxicas e climáticas, os seus condicionantes para a economía e a forma de vida. Así e todo, é difícil atopar o emprego da palabra paisaxe. Esta aparecerá, non obstante, a finais dos anos setenta en Francia, a principios dos oitenta no mundo anglófono e outros países. Persoalmente utilicei esta palabra no título da miña monografía Antropología de un viejo paisaje gallego, no ano 1984. O emprego do concepto de paisaxe entronca cunha determinada maneira de entender a Antropoloxía e supón, de ordinario, un distanciamento das posturas tradicionais do ecoloxismo e materialismos culturais dos anos sesenta e setenta, para os que sería difícil poder utilizar esta palabra. A relación cun estilo humanista de facer Antropoloxía e con certo tipo de inquedanzas filosóficas, dun xeito ou doutro, está en consonancia cunha consideración intencional e interactiva do coñecemento do mundo, coa idea de que a paisaxe está na mirada.

A inquietude paisaxística de certos sectores da Antropoloxía aproveita as polémicas de críticos e teóricos da literatura e a arte. Seguindo a historia da paisaxe, nas súas análises podemos destacar certas dinámicas da súa representación que inspiraron reflexións antropolóxicas. En primeiro lugar, a representación da paisaxe medieval, sobre todo no Románico, supón un aproveitamento intensamente simbólico dos elementos da natureza: as súas cores, as árbores como a palmeira e o ciprés, ríos e montañas, aves e diversos animais son compoñentes simbólicos, ilustracións imaxinativas e sensoriais de conceptos relixiosos e místicos. Naqueles tempos xogou un papel simbólico representado de forma abstracta, pero que segue a ter relevancia nas etapas posteriores. Outro eixe de desenvolvemento teórico son as distintas formas máis realistas ou máis subxectivas 
de representar a paisaxe. O realismo renacentista aproveita toda unha complicada técnica pictórica ao servizo do fiel reflexo da realidade contemplada. L'agneau mistique reproduce na súa pradaría, con fidelidade de botánicos, máis de trescentas especies vexetais perfectamente definidas e copiadas. Así e todo, as reflexións de historiadores e teóricos da arte destacan que o seu exceso realista representa un mundo imposible de ver, polo menos desde unha soa perspectiva. Detrás do seu aparente radical empirismo está toda unha complexa e fascinante elaboración subxectiva. Os séculos posteriores irán enchendo de subxectivismo o mundo da paisaxe con toda a interiorización barroca dun Rembrandt; a paisaxe vai copiando novas posibilidades de expresión de íntimas vivencias. Outro dos fundamentais desafíos da arte pictórica está no empeño en dotar de temporalidade a estática representación plasmada no lenzo. É a loita por suxerir o movemento, por provocar no que o contempla indicios que lle permitan percibir a inclusión do tempo. O Impresionismo foi o protagonista dunha importante inflexión co seu empeño por reproducir os distintos momentos luminosos xurdidos durante o día, da fachada da catedral ou dos palleiros campesiños, ou coa provocación ao espectador que o leva a moverse inquieto dun punto para outro, intentando percibir mellor ou descubrir distintas perspectivas, engadíndolle ao valor do cadro, a temporalidade cómplice do ir e vir da súa contemplación.

Os historiadores e teóricos da arte bríndanlle os seus propios desafíos á concepción paisaxista dun antropólogo e, xa no século XX, haberá ademais unha relación directa cos pintores coetáneos. A Antropoloxía Cultural constituirá un dos motivos que impulsan a varios pintores, a principios do século XX, a considerar o papel artístico dos chamados pobos primitivos, a reflexionar sobre se é ou non arte a súa obra e que tipo de estética encerra, ou a asumir as súas formas e cores como motivos evocadores da súa propia creación artística. Será especialmente a estreita relación entre os pintores surrealistas de París e os antropólogos fundadores do Museo do Home a que foi recollida recentemente por algúns historiadores da Antropoloxía (por exemplo, J. Clifford, 1988). Diriamos que, en definitiva, haberá unha sintonía entre as vangardas pictóricas e as antropolóxicas co discorrer do século. Uns e outros insisten no máis invisible da paisaxe, en aquilo que non se capta nunha primeira aparencia ou co simple sentido común; que códigos ou esquemas se precisan para representar, 
que relacións subxacentes e invisibles a unha primeira mirada nos permiten entender tanto a paisaxe como a nosa representación desta.

A pintura é unha fonte especial de desafíos, pois empénase en representar visualmente aquilo que non parece posible ver e plasmar nunha imaxe estática. Por suposto, o que o antropólogo acaba por facer é Etnografía, describe, non pinta. Aquí as suxestións da literatura poden facerse máis inmediatas, máis facilmente traducibles á descrición do etnógrafo. Ao influxo dos literatos da paisaxe temos que sumar e darlle relevancia ao dos grandes teóricos e críticos da literatura, entre os que Bajtin sería un autor paradigmático.

Hai no uso da palabra paisaxe outra importante fonte de reflexións para a tarefa antropolóxica. A paisaxe e o seu campo conceptual e semántico son un privilexiado terreo para a metáfora intelectual. Xa foi analizada por diferentes antropólogos (entre outros, A. Salmond, 1982) a especial predilección do mundo occidental pola expresión figurada do coñecemento en termos de metáforas espaciais. Falamos así de paisaxes intelectuais, de ver e contemplar novas ideas, da luz que ilumina, da claridade do bo entendemento, da ventá ou a porta que se abre a novos espazos ou áreas do saber, do background intelectual, dos sólidos alicerces da teoría, do coñecer entendido como unha viaxe, do camiño, do pro-greso -que en latín significa dar pasos cara a diante-, do meta-odos -do camiño a través do que-, das fronteiras disciplinares, das áreas de coñecemento, das areas do debate, das fontes documentais ou das fontes do saber en xeral...; ao comezo desta exposición entendemos a Antropoloxía como unha canle sinuosa e falamos de conceptos esvaradíos. Quizais entre tantas incontables metáforas espaciais, cheas de poder evocador, capaces de consolidar a nosa comprensión dos procesos abstractos, haxa algunhas máis densamente teóricas e indispensables; eu destacaría, como predilecto, o concepto de «horizonte», de fonda tradición na filosofía xermánica. O horizonte acompaña o viaxeiro mentres avanza por novas paisaxes, sempre ten no seu horizonte a mirada, un horizonte sempre novo, pero sempre seu, un límite espacial móbil que lle permite captar o relevo dos elementos que o rodean; o marco sempre fiel, sempre novo, sempre necesario para lle dar sentido á realidade. É o horizonte do coñecemento e o horizonte do ser.

A palabra paisaxe, en Antropoloxía, ten tamén o seu campo semántico peculiar e o seu conxunto de conceptos cos que máis estreitamente se relaciona: os 
binomios espazo e sitio -place-, espazo e tempo ou espazo e temporalidade, espazo e tempo simbólicos, cosmoloxía... Para un antropólogo que centra a súa análise nestes termos, encaixará moi ben no seu estilo o uso aquí e acolá do concepto de «paisaxe», ben como título ou salientado en certos momentos. A «paisaxe» do antropólogo está feita de «sitios» socialmente construídos, dotados de significado, «sitios» que interactúan en rede; a súa paisaxe é a linguaxe dos sitios.

Deste xeito, a Antropoloxía da paisaxe participa estreitamente -noutra relevante dinámica- na historia e a discusión filosófica dos conceptos de espazo e tempo. Son os eixes da vella Cosmoloxía aristotélica, elementos de discusión interminable ao longo da historia da Filosofía europea. Na Idade Moderna, fronte á «obxetificación», homoxeneización e cuantificación do espazo e o tempo físicos, a Filosofía empirista empeza a entendelos como ideas organizativas do noso proceso intelectual. Será sobre todo Kant o que formule radicalmente a súa cuestión das categorías fundadoras e universais do noso coñecer. E será o espírito postkantiano o que manteña o debate sobre o carácter intrinsecamente cognoscitivo e mesmo vitalmente humano do noso espazo e o noso tempo. Esta percepción empírica fala sobre todo de experiencia vital ou existencial: o espazo e o tempo dunha weltanschaunng, ou mellor, dunha lebenswelt.

O concepto de paisaxe, en Antropoloxía, xorde así en estreita comunicación con outras disciplinas, pero en contacto ou en contraste con todo iso, a sinuosa canle do antropólogo brinda unha peculiaridade. A tarefa tradicional da Antropoloxía caracterizábase polas súas longas viaxes a terras remotas e estrañas e o seu traballo de campo consistía nun longo tempo de estreita convivencia e participación na vida do grupo -ordinariamente pequeno- que se estudaba. É un grupo concreto de persoas coñecidas en contacto cara a cara e é tamén un ir e vir continuo, durante un ou máis anos, polos vieiros e camiños do seu territorio, polas calexas e ámbitos dos seus poboados. Alí se fragua a paisaxe das súas descricións etnográficas. $\mathrm{O}$ antropólogo chega cunha riqueza humanística e intelectual, cargado de conceptos estéticos e teóricos da vella civilización europea. Chega a un novo mundo, non menos antigo e intensamente vital. Ten que aprender os seus conceptos e valores, a heteroxeneidade dunha paisaxe ás veces sagrada; outras, prohibida; outras, privada -cando non se sabía que o era. Unha paisaxe feita de fitos e recunchos emotivos, ás veces dolorosos, outras, pletóricos de alegría. Ten que aprender a mirar, a «conceptualizar», a comprender unha 
nova paisaxe. Trata de copiar a súa maneira de facer na paisaxe en que vai descubrindo unha certa coherencia. A paisaxe exótica converteuse en familiar, é agora a súa paisaxe, a da súa vida cotiá.

A palabra clave é o concepto de significado da paisaxe, construción significativa dos sitios, conxugados coa mobilidade do corpo e do seu espazo, dentro do marco dunha cosmoloxía. O significado non é a maneira de representar a súa paisaxe os protagonistas da escena, nin tampouco como eles explican ou interpretan a súa representación da paisaxe. $\mathrm{O}$ antropólogo trata de captalo a través da observación e a convivencia, nunha continua interacción entre o que din e o que fan. A acción social significativa, a practice, o uso dos diferentes espazos polos que camiñan, onde se deteñen, onde repiten a súa presenza insistentemente, que accións levan a cabo en cada espazo, como se relacionan en grandes grupos ou se illan ou van na procura da intimidade do pequeno grupo ou fan público o espazo. Hai que velos vivir e acompañalos. Pero non basta con observar e participar activamente, cómpre falar, preguntarlles. $\mathrm{O}$ que din ilumina novos campos para entender e ser quen de observar con novos ollos o que fan, e esta renovada observación esixe formular novas preguntas. Aprendendo a preguntar, a mirar, comezamos a comprender o que aquel escenario «significa».

Os actores modifican, inflúen, impactan, constrúen a paisaxe. As paisaxes construídas non son só as edificacións, os muros ou os elementos arquitectónicos, adoitan ser tamén construción a fraga, os prados ou as terras de cultivo. O influxo físico e a presenza do ser humano chegan practicamente, dun xeito ou doutro, ata os máis afastados recunchos. Con máis ou menos intensidade, a paisaxe -urbana ou rural- é construída ou influída fisicamente, pero, sobre todo, a paisaxe é construción moral e simbólica, mesmo desde o primeiro momento do contacto cunha nova paisaxe. Resulta difícil poder atopar na actualidade a imaxe dunha natureza prístina, soñada como espontaneidade, completamente independente da acción humana. Pero, aínda que puidese descubrirse unha prístina natureza, será percibida e entendida culturalmente polo ser humano desde o primeiro momento e pensará en utilizala, en contemplala ou nas posibilidades de transformala culturalmente. Para a experiencia humana non existe a prístina natureza como punto de partida, xa desde o principio se atopa fronte a unha paisaxe.

Con isto situamos, nun primeiro enfoque tradicional, o tema da paisaxe na Antropoloxía; enfoque fundador de novas formas xurdidas nos últimos anos e 
ás que atenderemos en tres situacións teóricas. Esta primeira ofrécenos a aproximación propia dunha Antropoloxía estrutural, que se transformará despois en Antropoloxía simbólica. A paisaxe aparece construída a través dunha organización lóxica. Hai que comprender os estilos de pensar de cada cultura para poder captar en que tipo de paisaxe viven. O descubrimento da lóxica da conexión dos compoñentes simbólicos, dentro dunha maneira de vivir, constituirá a clave deste procedemento. A arquitectura simbólica do espazo constrúese facendo fincapé en esquemas e articulacións fundamentais, entre outros: o concepto de límite, as relacións da paisaxe con outros compoñentes da mesma cultura e a estreita relación entre espazo e tempo.

Lévi-Strauss descobre nas súas análises dos mitos unhas novas posibilidades da comprensión da paisaxe, proxectando sobre esta a forza lóxica organizativa dos esquemas sintagmáticos e paradigmáticos. $\mathrm{O}$ sintagma, como a metonimia, fálanos de contigüidade, dunha orde estreita entre as partes, antes ou despois, acá ou acolá. Son os esquemas paradigmáticos, analóxicos -e na linguaxe, metafóricos- os que permiten relacionar entre si estreitamente diversos niveis da vivencia social, distintas capas da natureza e da cultura mutuamente complicadas. As paisaxes da costa noroeste do Canadá, onde habitaban os cazadores-recolledores Tsimtshian, aparecen nas análises levi-straussianas cheas de fortes conexións. Os feitos de subir polo río cara á montaña ou baixar cara á baía teñen estreitas implicacións económicas nos seus mitos. O salmón e o peixe candea, que ascenden polos ríos para desovar, serán pescados masivamente no seu descenso. $\mathrm{O}$ atraso deste movemento estacional dos peixes pode producir unha terrible fame, compensada despois co momento de prodixiosa abundancia da pesca. As disputas entre os cazadores de osos de arriba e os cazadores de focas de abaixo, dos pescadores de río e de mar, no seu ir e vir mítico, entrelázanse na narración cos problemas de organización de parentesco, de exogamias, de matrimonios con curmáns cruzados, de formas moralmente axeitadas de perpetuar as castes e de trabar a estrutura política. Os vales e os seus ríos, as nevadas montañas, os illotes da costa non son só Xeografía, senón tamén unha continua lección moral, visible nos mesmos sitios e accidentes da paisaxe. No fin de contas, Asdiwal, «transformado en pedra, así como a súa lanza e o seu can, poden ser vistos mesmo así no cumio da gran montaña do lago Ginadaos» (Lévi-Strauss, 1967). Todo o que pase por alí pode velo perennemente petrificado, 
pero tamén se coñece o punto medio equidistante entre a montaña e o mar, onde se xuntaron a nai e mais a avoa do mítico heroe, compartindo no momento da fame angustiosa a única baga seca que puideron atopar. A terra dos Tsimtshian, a través da súa riqueza mítica e as súas plasmacións locais, é unha Terra Santa local chea de recursos simbólicos capaces de entrelazar e darlles sentido ás normas e pautas da súa vida social e aos avatares do quefacer cotián. As secuencias da narración mítica entrelazan, en harmonía musical, os esquemas: xeográfico, cosmolóxico, de integración, sociolóxico e tecnoeconómico.

Pero as continuidades sintagmáticas e os saltos analóxicos relacionados necesitan unha fragmentación espazo-temporal, unha heteroxeneidade que permita asentar nas súas diferenzas unha armazón significativa e unha orde da vida humana que nestes ámbitos se desenvolve. $\mathrm{O}$ concepto de «límite» convértese na Antropoloxía simbólica nunha fonte de inspiración teórica para a mellor comprensión da forma de vivir o espazo. O límite aparece como o lugar de ninguén, o espazo ambiguo. O límite non lle pertence a ningún dos espazos colaterais e é el mesmo un elemento tan só diferencial, carente de realidade espacial. Así e todo, a cultura trata de dotalo de realidade, de construílo física ou simbolicamente, dado que é indispensable para o seu xeito ordenar categorialmente o mundo. Álzanse así as murallas, as fronteiras, os modestos muros de pedra que separan as leiras, as pedras agachadas dentro do terreo -fitos- que serven como testemuño da liña ideal que separa terreos. Póidase ou non lograr a materialización física deste espazo non espacial, cómpre traballar intensamente pola construción de compoñentes simbólicos. Será o límite un referente perigoso, poderoso. Iluminarase a súa crenza, coa que se explican os castigos, de que quen incumpre as normas delimitadoras terá que sufrir. Os límites espaciais son lugares cargados de normativa moral e de imaxinación cultural que tratan de evitar a súa profanación.

Os límites espaciais teñen un correlato directo nos límites temporais. A continuidade día a día do calendario anual verase rota por momentos festivos que expresan a fin dunha etapa e o comezo doutra. As festas apoiarán a súa forza sagrada no seu carácter delimitador, no seu momento excepcional de tempo sen tempo. Unha semana separarase da outra por medio dun día festivo, santo, que non conta como os días laborables normais, e a noite dividirá os días. Espazo e tempo interveñen intrinsecamente na comprensión e construción cultural do 
mundo. O ciclo vital do home será dividido tamén en momentos heteroxéneos, mediante a construción ritual dos chamados ritos de paso.

Espazo e tempo, estreitamente vinculados -tense falado dunha teoría da relatividade social- son expresados en forma estrutural por Evans-Pritchard, no seu clásico estudo dos Nuer. Trátase dun pobo que en 1930 descoñece o sistema métrico, non usa unidades de medida espacial, nin ten a arma minuciosa do reloxo como forma de medir precisas unidades temporais. Isto permítelle a Evans-Pritchard presentar a súa forma estruturada de entender o espazo e o tempo como estreitamente ligada á vida social. Pode así preguntarlles aos habitantes do poboado $\mathrm{A}$ cal dos poboados B ou C queda máis cerca. Todos estarán de acordo en que $\mathrm{B}$ está moito máis preto. Evans-Pritchard, co seu reloxo na man e o seu hábito occidental de tomar medidas, comproba que B está aproximadamente ao dobre de distancia que C. Hai unha razón lóxica, non obstante; o convencemento das xentes do poboado de que $\mathrm{B}$ está máis cerca vén xustificado porque en $\mathrm{B}$ teñen moitos máis parentes e amigos e van alí con moita maior frecuencia. Así pois, son as actividades sociais as que marcan estruturalmente o espazo e o tempo. A estación seca non comeza nun día numericamente marcado dun inexistente mes convencional, senón que empeza precisamente cando as xentes marchan co gando na procura de terreos verdecentes para alimentar os animais insatisfeitos. Gráficos espaciais e temporais marcan na cabeza dos Nuer a proximidade das castes emparentadas, nun mapa explicativo da forma estruturada de organización das súas avinzas socio-políticas que, asemade, son proxectadas nos esquemas residenciais das aldeas. A paisaxe espazo-temporal, a organización social, a forza do poder, a gandaría, a economía forman un todo integrado - na mente dos Nuer- no que uns compoñentes xustifican e explican os outros nunha rede de interaccións.

Achegándonos a un mundo máis inmediato e á nosa propia experiencia vital, o agro galego, cun hábitat maioritariamente disperso, brinda especiais posibilidades para este tipo de análises. A poboación esténdese pola campía e brinda a imaxe dun continuum difícil de fragmentar. Así e todo, a vida social necesita "categorizar», clasificar coa súa linguaxe a natureza e a propia sociedade, sendo clasificadores nas súas propias clasificacións. As formas de agrupación social e a configuración de valores sorprenden cunha notable heteroxeneidade 
en pequenos espazos. Na zona onde iniciei o meu traballo de campo -entre a costa de Miño e Pontedeume e o límite coa provincia de Lugo-, a mariña e a montaña contribuían a facilitar unha xerarquía bipolar (Fernández de Rota, 1984). Os conceptos de bonito ou feo da paisaxe para as xentes do medio rural atenden prioritariamente ao contido, fronte á tradición estética elitista, máis preocupada pola forma ${ }^{1}$. Algo é bonito cando resulta bo para a xente. Son boas para as xentes do campo as terras chás, fáciles de traballar e fértiles para o cultivo. Son malas, e xa que logo "feas» para a súa estética, as zonas montañosas, cheas de penedos e pendentes, máis espectaculares e atractivas para a estética de moitos turistas urbanos. As zonas máis montañosas son un «deserto". Por suposto, son espazos verdecentes, con fragas, abundantes regatos e pequenas fervenzas, refrescantes para a mirada da nosa poética convencional. $\mathrm{O}$ seu concepto de "deserto", máis en consonancia co sentido da palabra na literatura e na pintura baixomedievais e renacentistas, refírese a lugares pouco poboados, cunha natureza máis salvaxe, son as zonas máis remotas e opostas á vida urbana. As parroquias de montaña, máis feas e duras para traballar, afastadas das cidades e dos camiños principais máis transitados, tiñan unha negativa valoración que se viña plasmando, polo menos nos últimos séculos ${ }^{2}$, nun tipo de relación hipergámica: as mulleres de arriba procuraban casar cos homes de abaixo, e era claramente menor o número de mulleres de abaixo casadas con homes de arriba. No límite, a última parroquia de montaña vén sufrindo uns fortes índices de endogamia. Este xogo de diferenzas xerárquicas tan marcadas contribuía á tensión da zona e configuraba liñas fronteirizas onde os mozos dunhas e doutras parroquias organizaban pelexas colectivas, pequenas batallas campesiñas $^{3}$. Se a zona de montaña era menos bonita, era considerada máis pobre e atrasada, máis salvaxe, pero tamén máis natural e xa que logo máis santa, máis elevada na categoría de sacralidade. As romarías principais máis milagreiras e que atraían moita xente das mariñas celebrábanse en conventos ou capelas-santuario da montaña. O día da romaría a paisaxe, deserta de xente,

\footnotetext{
${ }^{1}$ P. Bourdieu destaca esta característica que observou tamén como típica das xentes do rural que coñece (Bourdieu, 1979).

${ }^{2}$ Teño datos tirados dos arquivos parroquiais, a partir do século XVIII.

${ }^{3} \mathrm{O}$ esquema que aquí analizo estivo vixente ata principios da década de mil novecentos sesenta. Na actualidade, como analizo na obra Los protagonistas de la economía básica, a transformación foi moi profunda, aínda que certos esquemas xerárquicos se manteñan (Fernández de Rota, 1998).
} 
transformábase en multitude. As orgullosas xentes «da mariña toda» viñan sandar os seu familiares ou os animais enfermos. Asistían devotamente á procesión e miraban con todo respecto os seus poderosos santos patróns; moitos ascendían a última congostra empinada de xeonllos. Era a inversión simbólica, a compensación simbólica, a que dotaba os últimos lugares dun máis valioso poder. A fragmentación e mais os límites parecían resolverse estruturalmente no carácter radicalmente liminar do último chanzo, do santuario cronotopicamente convertido nun lugar de culto. Os diferentes niveis culturais parecían explicarse uns aos outros, nos seus xogos de analoxías e contrastes mutuos. Só atendendo a diferentes códigos analóxicos tiña sentido cada narración sintagmática. Só a profundidade histórica e o carácter intensamente temporal do espazo nos permite contextualizar o significado desta paisaxe integrada nunha lebenswelt.

Deixemos aquí esta breve evocación dunha rica forma de entender a paisaxe dun xeito integrado no conxunto dunha vida social e cultural, e pasemos agora a contemplar -nun segundo momento histórico- a imaxe dunha ruptura social, vivencial, cultural, a imaxe da cultura «desterritorializada» dun mundo en intensa "globalización». Este mundo de territorios «deslocalizados», de formas de vida arrancadas dunha paisaxe e de novas paisaxes reconvertidas nas súas maneiras de vivir ten incidido moito na tarefa antropolóxica. $\mathrm{O}$ antropólogo adoitaba «localizar» no seu propio territorio un grupo local que previsiblemente habitara alí durante moitas xeracións. Aquel territorio concreto era parte integrante, inevitable, da súa maneira de vivir. Todas as súas vivencias, as súas pautas de conduta, o seu xeito de ritualizar, as súas construcións míticas, a súa organización de parentesco falaban da relación cun territorio. Así o caracterizamos no apartado anterior. Pero agora, a chegada do antropólogo ao espazo concreto, ao pretendido territorio do grupo que se quere estudar, adoita depararlle demasiadas perplexidades. Nalgúns casos, moitos dos seus habitantes foron marchando nos últimos anos; como dirá Appadurai, uns marcharon e outros pensan en cando marcharán (Appadurai, 1991). Noutros lugares, a meirande parte das persoas que atopamos non naceron alí e chegaron hai pouco tempo: algúns acaban de facelo. Os máis antigos falan dos que viñeron hai tempo e logo marcharon a outro lugar ou dos que xa levan tanto tempo alí que empezan a sentir aquel territorio como seu. Os novos medios de comunicación, a profunda reorganización económica e política do noso mundo actual mostran en todas as partes un 
intenso fluxo de seres humanos que recobre, con vectores espaciais de todos os tamaños, a superficie do globo. Pero, ademais, o fluxo de mercadorías e de ideas é aínda máis intenso. A velocidade de transformación das paisaxes vexetais, das infraestruturas de comunicación e de explotación, a transformación de construcións urbanas e de amplos espazos satélites da cidade ofrecen con frecuencia unha imaxe de vertixinoso cambio. Pero, como se pensa e se entende esa paisaxe?, como se simboliza e normativiza moralmente?, como se narra?, cal é o territorio?, é que hai un territorio? Para a mentalidade do antropólogo, afeito a percorrer longas distancias para atopar un remoto recuncho, supostamente ancorado no tempo e densamente vivido por un grupo humano, esta transformación masiva de circunstancias constitúe un especial desafío. Se antes o antropólogo era o que se movía e os suxeitos que estudaba estaban quietos no seu espazo, agora estes tamén se moven con grande intensidade e fan que moitas veces teña que perseguilos por distintos e afastados lugares.

Pero, malia todo, o antropólogo comprende que cómpre estudar o comportamento da xente nos lugares onde habitan para entendela mellor; aquel ou aqueles sitios onde pasan unha parte importante da súa vida, aquel espazo íntimo de convivencia cotiá, aqueles marcos espaciais polos que discorre o seu quefacer e os seus hábitos. O antropólogo, afeito a estudar mediante prolongada convivencia, volve valorar a paisaxe humana, aínda que adaptándose ás novas circunstancias.

Será Arjun Appadurai o que acuñe o paradigmático termo de ethno-scapes (Appadurai, 1991). A palabra inglesa land-scapes permítelle xogar cos seus compoñentes: no canto da terra, a etnia. Non é en realidade algo tan novo. $\mathrm{O}$ antropólogo sempre pensaba que o máis importante da paisaxe era a xente que o habitaba, os individuos convivindo en grupos e as formas de organización identitarias do grupo. Agora, non obstante, a paisaxe volveuse máis viaxeira. Se atendemos a una diáspora de comerciantes provenientes do Norte da India, que organizan o seu comercio familiar en Ciudad del Cabo, que se establecen e teñen os seus fillos en Panamá e despois se asentan en Francia, no momento de entender a configuración identitaria deste grupo, non podemos prescindir da paisaxe -neste caso das diferentes paisaxes- que forma parte integrante da construción da súa «etnicidade». En 1991, puiden visitar Macao, daquela aínda portugués; non era doado, así e todo, atopar na rúa alguén que falase inglés, 
e menos aínda portugués. Subindo pola escalinata da vella igrexa de San Francisco Xavier, preto da Fortaleça vin un home de pel escura, que non parecía chinés; fun onda el e pregunteille se falaba portugués, e díxome que así era. Explicoume que era goés, natural de Goa, alí nacera e pasara a súa mocidade; era completamente portugués e sentía un claro fervor patriótico. Cando Goa pasou ás mans da India, decidiu marchar a Macao, co que os seus fillos tamén naceron en Portugal e viviron nun ambiente familiar portugués. Un ano antes do noso encontro, visitara por primeira vez a metrópole portuguesa, nunha excursión organizada; pareceulle todo unha marabilla e quedou encantado: «Xa ve, con sesenta anos e sendo sempre tan portugués non a coñecera nunca». Faltaban xa poucos anos para que Portugal lle devolvese Macao á China continental: «onde irei agora?», dicía. Estaba clara a forza do seu vital etno-scape, do que participaban tamén os seus fillos e netos. Era necesario entender a súa paisaxe étnica dunha forma axeitada.

Todo isto fai que nos reafirmemos cada vez máis na consideración da paisaxe antropolóxica como un conxunto de «sitios». Cada «sitio», construído historicamente, dotado de sentidos cambiantes, un espazo cheo de significado e moralidade que serve de áncora de duradeiras experiencias ou que é protagonista de momentos de especial transcendencia. Hai sitios de evocación relixiosa, étnica ou estética, de concentración de poder e de articulación espazo-temporal de poder hexemónico; hai tamén sitios de resistencia, de reivindicación, de protesta. Se entendemos que o ser humano é o corazón da paisaxe, só podemos comprender adecuadamente a paisaxe como unha pluralidade de sitios entre os que creamos e recreamos, na vida cultural, estreitas relacións de proximidade espazo-temporais -no «sentido Nuer»-, sitios enormemente próximos na intensidade da vivencia.

Por suposto, o outro compoñente fundamental para a nosa axeitada comprensión antropolóxica da paisaxe é o corpo humano. Trátase de espazos corporalizados, paisaxes percibidas polos sentidos corporais vividas e transformadas polo corpo. Estamos a falar xa da relación da paisaxe cos movementos do corpo, da configuración da paisaxe segundo estes movementos e do carácter intrínseco á vida humana do medio natural que contacta con el como paisaxe. Na nosa paisaxe hai un diante e un detrás, unha dereita e unha esquerda, un arriba e un abaixo, a partir do carácter dicotómico do noso corpo. Ademais, a paisaxe humana adoita ter os seus ámbitos masculinos e femininos, ao corpo xenérico 
correspóndelle unha paisaxe xenérica. A construción cultural da identidade xenérica foi estudada en multitude de casos culturais ${ }^{4}$. Corpo, espazo e movemento; Nancy Munn falará de «campo espacial móbil»-relacionado cos conceptos de Lefebvre, «campo de acción, base de acción»- que ela entende como un campo corpóreo-sensual culturalmente definido (Munn, 2003). Campo que se proxecta desde o corpo quer nun lugar dado, quer movéndose a través de diferentes lugares. Hai circunstancias espaciais que acompañan como unha paisaxe móbil o movemento do corpo humano. Hai espazos e paisaxes diferentes segundo os xéneros, as idades ou as diferentes categorías sociais. Abrímonos, así, plenamente, a unha terceira fase na comprensión antropolóxica da paisaxe que se move entre a fenomenoloxía e o postestruturalismo.

Son coñecidas as formulacións foucaultianas no tocante ás estratexias espaciais de control social a través da análise da relación do corpo humano coa organización do espazo da arquitectura. O seu influxo abriu a Antropoloxía ao interese por examinar as relacións do espazo co poder e o coñecemento. As distintas formas de construír física e simbolicamente o espazo, a arquitectura de paisaxes rurais ou urbanas poden ser entendidas como unha tecnoloxía política para acadar os obxectivos da gobernación, o control sobre os individuos. Con isto parecen ameazar a paisaxe os nuboeiros dunha amarga e penetrante crítica, as dimensións morais e políticas reflexivas constitúen o firmamento dun novo horizonte da paisaxe antropolóxica. Todo isto plasmarase, atendendo á súa canalización espacial, na vida diaria. É famoso o exemplo do panóptico de Bentham, utilizado por Foucault para explicar o obxectivo de crear un corpo dócil a través do encerro e organización do individuo no espazo.

O antropólogo Paul Rabinow, na súa obra French Modern, relaciona o crecemento de formas de poder político na evolución de teorías estéticas, que se concentran na organización do espazo como forma de entender «os lazos historicamente variables entre as relacións espaciais, a estética, a ciencia social, a economía e a política» (Rabinow, 2003). O seu estudo da planificación urbana no Marrocos colonial destaca, por exemplo, a configuración de dúas cidades distintas nas principais poboacións marroquís. Por unha banda, a medina, coas súas canellas angostas, ás veces murada, e pola outra, a uns poucos quilómetros,

\footnotetext{
${ }^{4}$ Véxase a introdución de S. Low e D. Lawrence-Zúñiga (Low e Lawrence-Zúñiga, 2003).
} 
a nova cidade colonial, de grandes avenidas e bulevares espazosos para o tráfico, propios dunha cidade racional moderna. O contraste entre as dúas era unha continua lección política -tanto para marroquís como para franceses- que manifestaba a supremacía dunha planificación racionalista, pragmática, progresista, moderna, expresiva do espírito francés, propia dunha mentalidade «colonial occidental»; fronte á vella, deteriorada, fedorenta, depauperada "medina», expresiva dun nivel inferior de civilización.

Un dos intelectuais que abordaron este tema de xeito especialmente suxestivo, e estreitamente vinculado ás inquietudes antropolóxicas, foi Michel de Certeau. A súa preocupación céntrase na recuperación do individuo fronte á disolución política ou ideolóxica deste. É nos pequenos grupos sociais e na súa capacidade de resistencia, subliñando a súa plasmación espacial, onde el descobre o seu obxectivo. Chamaralle «formas de operar» á maneira en que os usuarios constitúen os medios polos que se reapropian o espazo. «Son prácticas que se articulan nos detalles da vida cotiá e sacan á luz as tácticas clandestinas usadas por grupos ou individuos xa capturados nas redes da disciplina» (De Certeau, 1990). Trazando as súas maneiras de andar, nomear, narrar, lembrar a cidade, desenvolve De Certeau unha teoría do espazo vivido na que se elude a planificación urbana. Os camiñantes, andando na actualización do sitio, crean e representan o espazo público, no canto de estar suxeitos a el. O poder exércese sobre territorios e fronteiras, onde as armas dos fortes son a clasificación, delineación e división. Son chamadas por el «estratexias». Fronte a elas, as armas dos débiles -«tácticas»- son movementos furtivos, pequenos cortes e itinerarios para contestar o dominio espacial. Son unha forma de consumo que non produce sitios propiamente ditos, senón que usa e manipula estes sitios. A nosa paisaxe foise convertendo nun xogo de forzas, de poder, de loitas entre hexemonía e resistencia, de iniciativa e imaxinación, fronte a rutina e disciplina. É unha paisaxe feita de grandes normas ostensibles e de rupturas, pequenas, minuciosas, convivenciais, portadoras de distintos valores morais.

A imaxinación teórica destes movementos ábrenos a conceptos como hiperrealidade e hiperespazo. Xorden cidades como Disney World, modelos perfectos de simulación. É a cidade da ilusión: o cine e as representacións etnográficas estruturan alí a nosa experiencia con actividades organizadas como escenas de película. Dirá Baudrillard: «Disneyland preséntase como imaxinaria co obxecti- 
vo de facernos crer que o resto é real, cando en verdade todo o Orange County e a América arredor non é máis real, senón que é a orde do hiperreal e a simulación» (Baudrillard, 1988). As cidades non fantasiosas están cheas de sitios eminentemente escenográficos organizados en relación con determinados mecanismos de consumo.

Pero, ademais destas paisaxes relativamente máis duradeiras, a nosa imaxinación fai que pensemos con facilidade a paisaxe desde as vivencias de turista, dos moi diferentes tipos de turistas, consumidores de paisaxes de moi diversas formas e cuxa actividade inflúe profundamente non só na transformación física da paisaxe, senón tamén na construción simbólica e moral dos residentes. Normalmente adoitamos centrarnos sobre todo nos aspectos máis destrutivos desta transformación, amplamente criticados, pero quedaría incompleta a nosa breve consideración se non temos en conta o influxo na reconsideración identitaria e étnica e na revalorización de tantos lugares ou na colaboración á construción imaxinativa de novos sitios estables de penetrante influxo cultural.

Entre a potenciación ideolóxica da identidade «recibida dos antepasados» e a oferta ao crecente turismo, ávido de diferenzas culturais «típicas» e de referentes a tempos pasados, xorden a moreas as novas paisaxes "patrimoniais», cada vez máis ilimitadas, que condicionan o resto da paisaxe. Son paisaxes intensamente representativas, heterotópicas, profundamente implicadas nas ansiedades sobre o que se perdeu e o que debe ser preservado, esforzo colectivo por perpetuar a continxencia na procura da autenticidade. É unha situación limítrofe, próxima ao sagrado, onde o tempo espacializado se fai paisaxe mítica. Sobre o tema da reconstrución patrimonial, M. Herzfeld ofrécenos outro tipo de paisaxe referido á vella cidade histórica de Rethemnos. Preséntanse diante dela as visións conflitivas da historia. Hai tantas historias como presentes. Cómpre descubrir quen decide o que constitúe a historia do sitio e como é negociada a materialidade da súa historia. A nosa paisaxe, intensamente ideolóxica, abunda en lugares de afirmación e lugares de contestación. Están inscritos onde a escritura deixou gravada a forza do seu significado, poden ser o escenario das máis sanguentas batallas ou das máis solemnes reconciliacións, hai sitios e paisaxes radicalmente históricos.

A nosa paisaxe íntima de antropólogos non foi nunca tan bucólica e apracible como a súa evocación exótica parece suxerir. A paisaxe é tan intensamente dramática como a propia vida humana, só entendemos a paisaxe co vivir dos 
nosos corpos e non pode haber corpos vivos sen paisaxe. $\mathrm{O}$ carácter inmediato local da comprensión dos espazos do vivir cotián foise abrindo, cada vez máis, cara á comprensión dunha magna cartografía política da que forman parte. Non é posible entender a súa contigüidade cotiá sen facer referencia con claridade ao cúmulo de vectores económicos e políticos que nela conflúen. Pero tamén é verdade que as magnas cartografías e os grandes números non poden nunca recoller as máis típicas vivencias dos seres humanos. Cada concreto caso de paisaxe de estudo é unha condensada exemplificación da transformación global da paisaxe. É tamén no seu pequeno ámbito local onde podemos percibir a capacidade creativa do home, aberta sempre a novas posibilidades de compromiso coa paisaxe. 


\section{BIBLIOGRAFÍA}

AppaduraI, A.: «Global Ethnoescapes: Notes and Queries for a Transnational Anthropology», en R. G. Fox (ed.): Recapturing Anthropology. Working in the Present, School of American Resarch Press, Santa Fe, 1991.

Baudrillard, J.: Selected Writings, Stanford University Press, 1988.

Bourdieu, P.: La Distinction, 1979, Les Éditions de Minuit, Paris. [Hai edición en castelán].

CerTEAU, M. DE: Linvention du quotidien, Gallimard, Paris, 1990 (orixinal 1980). [Hai edición en castelán].

Clifford, J.: Predicament of Culture, Harvard University Press, Cambridge, 1988. [Hai edición en castelán].

FERNÁNDEZ DE ROTA, J. A.: Antropología de un viejo paisaje gallego, CIS-Siglo XXI, Madrid, 1984.

FERnÁndez de RotA, J. A.: Los protagonistas de la economía básica, Deputación, A Coruña, 1998.

LÉvI-STRAUSS: «Gesta de Asdiwal», en Estructuralismo, mito y totemismo, Nueva Visión, Bos Aires, 1967.

Low, S. e D. LaWrence-ZúNiga: «Locating culture», en S. Low e D. LaWrence-ZúñIga (ed.): The anthropology of space and place. Locating culture, Blackwell Publishing, Oxford, 2003.

Munn, N.: «Excluded Spaces: The Figure in the Australian Aboriginal Landscape», en S. Low e D. LAWRENCE-ZÚNiga (ed.): The anthropology..., op. cit.

RabinOw, P.: «Ordonnance, Discipline, Regulation: Some Reflections on Urbanism», en S. Low e D. LAWRENCE-ZÚNIGA (ed.): The anthropology..., op. cit.

SAlmond, A.: "Theoretical Landscape. On a Cross-Cultural Conception of Knowledge», en D. PARKIN, (ed.): Semantic Anthropology, Academic Press, London, 1982. 
Retruque

CARA A UNHA TEORÍA
INTEGRAL DA PAISAXE

Federico López Silvestre

Universidade de Santiago de Compostela 

O tema que se presenta na primeira parte deste foro aféctalles a todas as disciplinas. Moitos científicos tenden a crer que a paisaxe é, simplemente, aquilo que nos rodea. Pola contra, moitos humanistas pensan que a paisaxe é só un efecto da mirada. Este texto tratará de demostrar que, historicamente, o concepto nunca foi un sinónimo exacto da idea de territorio, senón que naceu das mans dalgúns pintores e escritores do século XVI para facer referencia a unha extensión de terreo valorada artisticamente. Houbo alguén antes deses pintores e escritores que xa sentise a paisaxe? Precisamente ese é un dos grandes debates aos que asistimos actualmente no eido das humanidades. Se ben certos autores consideran que a experiencia viaxeira, que sempre existiu, pode compararse á éxtase paisaxística, outros afirman que só se pode falar de paisaxe desde o momento en que apareceron a palabra e a arte da paisaxe. Pero, vaiamos por partes.

Era paisaxe aquela galaxia en expansión que comezou a agromar 300000 anos despois do big bang? Era paisaxe a superficie da terra no precámbrico cando o globo estaba anegado polas augas inzadas de minúsculas algas e de células eucariotas ou procariotas? $\mathrm{O}$ científico materialista, que presupón a existencia de todo, ou practicamente todo, sen necesidade de que haxa alguén para percibilo ou concibilo, non dubidará en afirmar que si, que aquilo xa era paisaxe. Hai unha tendencia no eido das ciencias ambientais que insiste en identificar a paisaxe con algo que estaba aí antes da paisaxe. Así e todo, debemos comezar por distinguir ambos os dous estadios: o do mundo como paisaxe e o do mundo como algo anterior á paisaxe, como algo que podemos chamar «mundo en si».

\section{A PAISAXE COMO BOLBORETA}

Hai uns anos, utilicei a metáfora da naftalina para facer referencia á xénese da paisaxe. O naftaleno é un hidrocarburo aromático que se atopa no alcatrán de hulla, de onde se obtén por destilación. Por acción directa da calor, a espesa, 
negra e cheirenta brea vai deshidratándose e, dependendo das temperaturas alcanzadas, orixina diferentes compostos orgánicos. A uns $218^{\circ} \mathrm{C}$ o naftaleno contido no alcatrán comeza a ferver. Polo efecto da sublimación, os gases que se obteñen coa ebulición cristalizan e acaban por converterse na materia branca e aromática que todos coñecemos co nome de naftalina. O proceso de formación da naftalina garda un notable parecido cunha das teorías do coñecemento de maior arraigamento en Occidente. Entre a materia en bruto que se aspira a coñecer e o produto xa refinado que se acaba coñecendo media algo semellante á destilación e á sublimación. Non importa tanto que se afirme que a «Natureza» existe e que o dato sensible constitúe o punto de partida do coñecemento, como que se acepte que só tras os filtros de selección e limpeza que introducen ollos e mente se conforma o que finalmente coñecemos. Sen dúbida, no proceso de coñecer o que o rodea, o ser humano introduce eses filtros, que fan que poidamos afirmar que unha cousa é o «mundo en si» e outra, a nosa representación fenoménica do mundo. Sexa como queira, agora vexo con claridade que, no caso da paisaxe, o proceso de filtración é dobre e a metáfora da naftalina queda curta. Mellor resulta a metáfora da bolboreta.

A paisaxe non é paisaxe unicamente por constituír a nosa representación do mundo e non o «mundo en si». Tanto o ambiente, como o país ou o territorio son conceptos, é dicir, representacións do "mundo en si», e, así e todo, non son exactamente o mesmo que a paisaxe. A paisaxe é un tipo especial de visión do país. Para chegar a esa noción, o «mundo en si» debe ser procesado de dous modos: primeiro, converténdoo -como o país- en representación ou imaxe mental do mundo -a vista ou panorámica concreta- e, despois, valorándoo, sentíndoo ou xulgándoo esteticamente. Neste sentido, á paisaxe ocórrelle como á bolboreta: para chegar a existir, debe sufrir unha dobre mutación. En primeiro lugar, debe nacer como verme ou «fenómeno» concreto -certa vista, certa panorámica, certo país- e, en segundo lugar, debe transformarse en bolboreta ou idea estética. Esa bolboreta pode ser diúrna, fermosa e rica en cores -Boavista, Vistalegre...-, ou nocturna, fea, acarunchada e ata terrorífica-Malpaso, Terramala... En todo caso, sempre se caracterizará pola súa aura estética, é dicir, por ser sentida ou xulgada esteticamente. Só aquela investigación que teña en conta que a paisaxe é como a bolboreta e que para entender a súa xénese debe contemplarse esa dobre mutación poderá darnos a medida exacta da súa natureza. 


\section{DO «MUNDO EN SI» AO PAÍS. A XÉNESE PERCEPTIVA}

A paisaxe é, en primeiro lugar, país, é dicir, representación ou imaxe dunha parte do mundo. Concretamente, é certa extensión de terreo que adquire unidade e independencia debido á atención que alguén lle presta. Malia o simple que pareza isto, o certo é que xa neste nivel cabe falar de proceso e de xénese. Máis aínda, probablemente a contemplación da paisaxe sexa o caso máis evidente que se poida atopar do esforzado labor primario de filtración que realizan os sentidos e a mente sobre os datos recibidos.

Por si mesmo, o material que compón o que chamamos paisaxe constitúe algo demasiado amplo e heteroxéneo como para que os cualificativos de obxecto ou cousa, no sentido que se lles dá a estas palabras na linguaxe cotiá, se adapten a el con facilidade. Por mor da falta de límites ben definidos, a paisaxe confúndese co continuum espacial e, a causa da disparidade de elementos que a compoñen -desde árbores e maleza, ata edificios e estradas-, subsiste como algo inconexo e caótico. Así e todo, malia estes inconvenientes, ese material aparece diante de nós con claridade, como se estivese xa dado, en definitiva, como unha paisaxe. Como é isto posible? Por que vemos a paisaxe? Pois ben, é posible vela grazas ás operacións psíquicas que realizamos inconscientemente ao percibir, pola filtración. Concretamente, no tocante á paisaxe, esa actividade interna resúmese en dous conceptos fundamentais: delimitación e unificación.

De orientar a definición da paisaxe na dirección oculta pero verdadeira do que se xesta na mente xa se encargou Georg Simmel a principios de século nun pequeno pero vigoroso artigo titulado «Filosofía da paisaxe». Malia non facer referencia ao que na súa época debían ser os últimos avances en Psicoloxía da percepción, as palabras de Simmel non erran cando se trata de localizar o problema inicial da súa xénese: «a delimitación, o feito de estar comprendido nun horizonte visual momentáneo ou duradeiro, é absolutamente esencial para a paisaxe». En efecto, se a natureza é «a conexión sen fin das cousas, o ininterrompido producir e negar de formas», a paisaxe, en cambio, é un "cacho», un «recorte» que insiste en separarse do absoluto. Fronte á inabarcable totalidade do mundo, a paisaxe «esixe un ser-para-si» e eríxese como entidade «autosuficiente» alí onde, a priori, a natureza diluía calquera fronteira. Agora ben, como indica o propio Simmel, se isto é posible, se é imaxinable que en certos momentos 
a unidade da natureza se rompa, é sempre por causa do home, do «horizonte visual» que comprende a súa mirada. O mirar desde un sitio, o ver desde certo punto, é invariablemente algo parcial. A parcialidade faise ostensible non só nos límites externos da nosa mirada, senón tamén en todo aquilo que, malia entrar dentro do noso campo visual, por estar oculto, deixa de verse. É aquí, desde esa evidente parcialidade que nos impoñen os sentidos, onde a paisaxe se define, simplemente, como o produto máis vasto ao que se pode aspirar.

Pero, como adiantabamos máis arriba, a percepción da paisaxe non só se explica mediante os conceptos de delimitación e parcialidade condicionados polo punto de vista. A delimitación do espazo visible supón xa un avanzar cara á unidade elemental que implica toda paisaxe. Non obstante, esa unidade é máis eficaz do que se podería supoñer se, unha vez extraído o recorte, se valorasen un a un os moitos ingredientes que a compoñen. Existe unha pintura xaponesa da última época Edo que representa a cabeza dun personaxe composta enteiramente a partir de figuras humanas. Do mesmo xeito que percibir a configuración de conxunto dese personaxe é cualitativamente distinto a ver os diversos corpos que o integran, o acto de contemplar a paisaxe non pode ser equiparado ao acto de discernir os elementos que a forman. Estes e mais os estímulos que xeran son tantos e tan diversos que, desde o principio, poñen de manifesto que, para facerse evidente, a súa reunión nesa totalidade coherente que chamamos paisaxe demanda algo máis que unha sinxela delimitación periférica.

Recentemente, un filólogo francés especializado na paisaxe, Michel Collot, apoiándose na Psicoloxía da percepción e, fundamentalmente, nas leis da Gestalt, foi quen de reducir a tres os procesos mentais de unificación interna que se atopan na súa xénese: a tendencia a seleccionar, a tendencia a relacionar e a tendencia a anticiparse. A primeira delas, a tendencia a seleccionar, ao atender a unha ou a poucas cousas, evita que a mente sucumba diante duna masa de información que, de calquera outro modo, non podería tratar. Ao facilitar a tarefa de selección, a liña do horizonte xoga un importante papel no discernimento da paisaxe. Por outra banda, a contemplación desa parte inferior non é posible unicamente por esa primeira extracción que consiste en separar a figura do fondo. O conxunto que delimita o horizonte aínda está composto por demasiados elementos como para atendelos a todos e, así e todo, vémolo. Se isto é así, se podemos observar a paisaxe, é debido a outro tipo de selección denominada simpli- 
ficación. Segundo o principio de simplificación, todo estímulo complexo tende a ser visto da forma máis simple que permiten as condicións dadas. De feito, só na medida na que poidamos descubrir, no confuso panorama, algúns elementos que sobresaen polo seu tamaño ou forma, algunhas cores e texturas, ou algunhas direccións especialmente significativas que nos dean una pauta a seguir, estaremos en condicións de afirmar que vimos a paisaxe.

Evidentemente, o proceso de simplificación ten moito que ver coa tendencia a relacionar ou agrupar, que, como xa indicamos, segundo Collot, é outro dos procesos que favorecen a constitución da paisaxe. O feito de agrupar os diferentes estímulos que recibimos en función da súa proximidade ou do seu parecido físico é unha inclinación que mostramos con especial forza cando miramos unha paisaxe. As decenas de matices de verde e as moi variadas distancias ás que se dispoñen as cousas tenden a constituír grupos maiores para favorecer a vision d'ensemble, é dicir, a visión de conxunto que fai posible a paisaxe.

Por último, a anticipación permite que o observador complete o inconcluso. Isto quere dicir que a mente non se conforma coas sensacións recibidas e que, se fose preciso, é capaz de ter en conta as prolongacións invisibles como partes do visible. O camiño ou o río que desaparecen detrás dunhas árbores hai que supoñer que seguen alí, e a percepción, malia non captalos, é capaz de telos en conta. Precisamente o feito de ter en conta o que non se ve é o que asegura que non haxa sobresaltos na exploración perceptiva, e o que, xa que logo, permite o paso sen rupturas dun aspecto ao outro, preservando a unidade do todo. Pois ben, se sumamos este último proceso aos dous anteriores e ao concepto de delimitación, teremos unha primeira resposta á pregunta de cal é a orixe da paisaxe. Aínda que a materia en bruto que a constitúe é o «mundo en si»-a «natureza»-, a paisaxe, como entidade autónoma e como totalidade coherente, é, efectivamente, o produto filtrado das xestións que a un nivel primario efectúa a mente.

\section{DO PAÍS Á PAISAXE. A XÉNESE ESTÉTICA}

Agora ben, con cifrar a xénese perceptiva da paisaxe non basta. A xénese perceptiva da paisaxe é similar á do país e, así e todo, hai séculos alguén decidiu inventar unha palabra para distinguir ambos os dous conceptos. Por que o fixo? 
Obviamente, porque a paisaxe é algo máis que o país. «A paisaxe é país estetizado, artializado, patrimonializado...».

Se estamos tan seguros do contido estético da palabra é por mor da súa orixe etimolóxica. O termo paysage naceu cargado de connotacións, por algunha razón, no século XVI, cando xa existían as palabras «terra» ou "país». Naquel momento, algúns pintores franceses consideraron necesario utilizar unha palabra diferente das que xa existían. En principio, para referirse á representación pictórica do "país»: un paysage era un cadriño que representaba a vista dun "país». Non obstante, pronto se estendeu a súa utilización ao propio país ou territorio. Comezaron, nesa época, a seren chamadas paisaxes aqueles conxuntos ou partes do país merecentes da mirada do pintor. En definitiva, a palabra paisaxe non naceu como sinónimo de territorio, país ou ambiente, cousa pola que hoxe tende a pasar, senón para ampliar o contido das anteriores, como termo estético, pleno de connotacións. Se ata o de agora un territorio ou un país eran certa extensión de terreo, a partir deste momento a paisaxe pasa a ser unha certa extensión de terreo que adquire unidade por medio da mirada dunha persoa que a valoraba en si mesma, é dicir, que a aprecia esteticamente.

$\mathrm{Na}$ actualidade, son numerosos os autores, chegados dos eidos da Xeografía, a Filosofía, a Historia da arte, a Arquitectura ou a Antropoloxía, que sosteñen que para definir a paisaxe cómpre ter en conta as dimensións humana e estética. O debate, neste sentido, consiste en saber cando naceu exactamente esa mirada estética que converteu o país en paisaxe. Pódese falar, fundamentalmente, de tres posturas. A que, seguindo a tese Whorf ou Sapir-Whorf, insiste na importancia da aparición dunha palabra específica cargada de connotacións estéticas para poder falar da xénese da paisaxe. A que, adoptando a postura propia dos historiadores da cultura ou da arte, prefire magnificar o valor do desenvolvemento de certas prácticas artísticas para referirse ao nacemento da paisaxe. E, finalmente, a que, seguindo a dos fenomenólogos, indica que non é preciso que aparecera unha palabra específica ou a arte da pintura para que se poida falar do florecemento de certa actitude "paisaxeira», xa que a devandita actitude pode reflectirse simplemente na aparición dunha figura como a do viaxeiro ou a do paseante. Vexamos estas posturas por partes e tratemos de extraer o que poida haber de bo en cada unha. 
Quizais a «experiencia primitiva da paisaxe» xa existía antes de que aparecesen a palabra e mais a pintura de paisaxe. Bastaría con que alguén quedase engaiolado contemplando unha fermosa vista para poder defender esta tese. Máis aínda, independentemente de que sexa no mundo moderno onde se desenvolve e no contemporáneo cando se vulgariza, é fácil supoñer que a experiencia paisaxista nacese antes do século XVI. É habitual referirse á ascensión de Petrarca ao Mont Ventoux para falar dese tipo de experiencia, pero, como é sabido, nos tempos de Petrarca non existía aínda a palabra paisaxe, nin se pintaban paisaxes autónomas. Houbo outros, antes de Petrarca, capaces de sentir a beleza do territorio aínda que carecesen da palabra ou do aval da pintura? As respostas a esta pregunta son diversas e motivo de polémica. Algúns, como Venturi Ferriolo, Milani ou Baridon, remóntanse á Antigüidade para facer referencia a ese tipo de experiencias. Para xustificar as súas afirmacións apóianse na xardinaría e na literatura. En todo caso, e tal como propón Careri, ¿non cabería pensar na existencia antes diso, mesmo na Prehistoria, de viaxeiros e nómades que, afeitos a percorrer certos territorios e a marcalos con pedras e sinais, establecesen vínculos simbólicos e afectivos con determinados países e aprendesen a apreciar determinadas vistas? Ou, máis sinxelamente: despois dun día de esgotadora marcha, non causaría a vista dun val verde inzado de árbores froiteiras unha alegría comparable a iso que chamamos pracer estético? Desde logo, os escasos textos dos peregrinos medievais que gardamos apenas fan referencia á paisaxe autónoma tal e como hoxe a entendemos. Así e todo, sempre que poden, introducen felices comentarios dos campos festivos, primaverais, cheos de árbores froiteiras...

Fronte á postura daqueles que remontan a «experiencia da paisaxe» a tempos inmemoriais, o criterio máis estendido entre os investigadores é o de vincular o seu nacemento coa arte. Como digo, algúns autores, como Milani, remontan esa relación á Antigüidade, á literatura e ás xardinarías grega e romana. Outros, como Berque ou Escande, insisten con razón en lembrar que noutras culturas como a da China esa arte naceu mesmo antes. Pero a meirande parte dos investigadores prefire defender que, polo menos no caso europeo, se trata dunha invención do Renacemento. Sería só ao comezo da Idade Moderna, e non antes, cando xurdiu a posibilidade de retratar unha vista como algo autónomo e digno de ser pintado por si mesmo, sen relación con historia nin relato ningúns. $\mathrm{O}$ 
certo é que a énfase no papel dos pintores na xénese da paisaxe xa foi sinalada desde o século XIX por historiadores da cultura como Jacob Burckhardt. Se a paisaxe é o país "estetizado», convertido en obxecto de contemplación, nada mellor que fixarse nos artistas para descubrir o momento da súa verdadeira xénese. A arte de Durero, de Patinir ou de Leonardo estaría no principio desa estética da paisaxe e tería que ver, como a excursión de Petrarca, cun cambio de mentalidade. O desenvolvemento do humanismo e do estudo da natureza implican, por unha banda, unha maior confianza nos nosos sentidos e no que estes nos ofrecen do mundo, e pola outra, un interese franco polas criaturas que nos rodean. Así, a orixe da paisaxe estaría vinculada coas novas ideas compartidas primeiro por algúns pioneiros e, máis tarde, polas clases cultas de Italia, Francia, os Países Baixos ou Alemaña. Esta é a tese defendida por Roger, Cauquelin, Maderuelo e moitos máis.

Finalmente, algúns investigadores afirman que só podemos estar seguros da aparición da noción de paisaxe no momento en que xorden a palabra ou palabras para nomear esta paisaxe. É completamente necesario que exista unha palabra para falar da existencia dunha noción? Velaquí un verdadeiro problema filosófico. Desde logo, para cifrar historicamente a evolución da mentalidade dunha sociedade, nada resulta tan eficiente como deixar constancia das novas palabras que esta é capaz de acuñar. A tese de Benjamin L. Whorf sostén que nada indica as diferenzas culturais entre os pobos de modo tan claro como o vocabulario. Existen pobos de África incapaces de contar máis alá do número cinco. Do mesmo xeito, os inuit distinguen con palabras decenas de tipos de neve que para nós resultan indiscernibles. Significa iso que aqueles que non posúan a palabra ou palabras para dicir paisaxe non poidan apreciala da mesma forma? Iso é o que, desde hai algúns anos, defende o xeógrafo francés Augustin Berque. Mediante un estudo comparado, Berque tratou de demostrar que só se pode falar de «sociedades paisaxistas» nos casos en que se posúe unha palabra específica para nomear a paisaxe. A modo de exemplo, Berque e os seus discípulos estudaron a aparición da palabra paisaxe na China, no Xapón e nos países da Europa Occidental. Só cando en Francia apareceu a palabra paysage, proposta polos pintores e cando na China xurdiu a palabra shanshui, o aprecio polo país en termos estéticos ou paisaxísticos acadou a súa maioría de idade. 
É indubidable que a aparición da palabra paisaxe marca un antes e un despois na xénese da idea. Sexa como queira, para que alguén considerase necesario inventala, sería preciso ter unha experiencia digna dunha nova palabra. Topónimos como Boavista, Vistalegre, Malpaso ou Terramala poñen de manifesto que o ser humano tiña ese tipo de experiencias moito antes de que nacera o concepto-palabra que hoxe nos ocupa. Así, como no nacemento da bolboreta, para cifrar a xénese deste cómpre referirse a varias fases: unha puramente perceptiva, unha afectiva ou sentimental e, finalmente, outra conceptual.

Schelling consideraba que o sentimental era o selo que a natureza deixaba no home e que esa natureza tamén tiña "alma», é dicir, subxectividade produtiva. A idea da produtividade ou creatividade da natureza suxire que toda filosofía integral da paisaxe debería proceder como fixo Humboldt: mostrando a natureza que hai na arte e a arte que hai na natureza. Volvendo á pregunta inicial, non sei se a galaxia inorgánica en expansión do big bang era paisaxe. Do que cada vez teño menos dúbidas é do carácter paisaxístico do mundo orgánico que precedeu ao home na escala evolutiva e cuxa beleza «artística» xa foi salientada por Ernst Haeckel. Velaí o nexo entre ciencias e humanidades, nexo encarnado na paisaxe. 


\section{BIBLIOGRAFÍA}

BARIDON, M.: Naissance et renaissance du paysage, Arles, Ed. Actes Sud, 2007.

BERQUE, A.: Les Raisons du paysage. De la Chine antique aux environnements de synthèse, Paris, Ed. Hazan, 1995.

BURCKHARDT, J.: «El descubrimiento de la belleza en el paisaje», en La cultura del renacimiento en Italia, Madrid, Ed. Escelicer, 1941, p. 185-190.

CARERI, F.: Walkscapes. El andar como práctica estética, Barcelona, Ed. Gustavo Gili, 2002.

Cauquelin, A.: Linvention du paysage, Paris, Ed. Librairie Plon, 1989.

Collot, M.: "Point de vue sur la perception des paysages», en A. Roger (dir.), La Théorie du Paysage en France (1974-1994), Seyssel, Ed. Champ Vallon, 1995, p. 210-223 (1 a ed. Paris, L'espace géographique, n. ${ }^{\circ}$ 3, 1986, p. 211-217).

EsCANDE, Y.: Montagnes et eaux. La culture du shanshui, Paris, Hermann, 2005.

Humboldt, A. von: Cosmos, Madrid, Rodríguez de Rivera, 1851-52, 2 tomos.

LÓPEZ SiLVeSTRE, F.: «A xénese da paisaxe», As paisaxes contemporáneas, Santiago de Compostela, Consello da Cultura Galega, s.d. (en prensa, aínda que os textos deste libro se reuniron a comezos do ano 2000). Maderuelo, J.: El Paisaje. Génesis de un concepto, Madrid, Ed. Abada, 2005.

Milani, R.: El arte del paisaje, Madrid, Biblioteca Nueva, 2008 (en italiano: Bologna, 2001).

SCHELling, F.: Sistema del idealismo trascendental, Madrid, Anthropos, 1988.

Simmel, G.: «Filosofía del Paisaje», en El Individuo y la Libertad, Barcelona, Ed. Península, 1986, p. 175 e ss.

Roger, A.: Breve tratado del paisaje, Madrid, Ed. Biblioteca Nueva, 2007 (1 a ed. 1997).

Venturi Ferriolo, M.: Etiche del paesaggio. Il progetto del mondo umano, Roma, Editori Riuniti, 2002.

WHORF, B. L.: Lenguaje, pensamiento y realidad, Barcelona, Ed. Barral, 1971. 


\section{DO TERRITORIO Á PAISAXE. ANÁLISE DA PAISAXE DESDE AS CIENCIAS AMBIENTAIS}



Relatorio

\section{ECOLOXÍA DA PAISAXE}

Francisco Díaz Pineda

Universidad Complutense de Madrid 

A paisaxe é un concepto antropocéntrico. Atópase na mente do observador, que recibe unha información do contorno a través dos seus sentidos. O lugar en que o observador se atope conterá compoñentes individuais propios do medio natural -rochas, solo, vento, nubes, plantas, animais- ou do ambiente cultural -cultivos, gando, rúa, xardíns, ventás, mobles. Estas cousas aparecen integradas na mente, formando unha imaxe. Nela poden focalizarse obxectos particulares, ruídos, olores, etc., ou grupos de obxectos. En conxunto, todos eles forman a paisaxe. O observador pode ser racional ou non, de xeito que a percepción da paisaxe atinxe ao entendemento daquel pero talvez non á súa conciencia.

Parece que, historicamente, o interese pola paisaxe como obxecto de atención centrouse máis en escenarios naturais e culturais rurais que en ambientes urbanos ou de interiores, tanto desde o punto de vista da arte como do das humanidades e a ciencia.

A Ecoloxía tense interesado pola idea de paisaxe desde diferentes perspectivas. Basicamente, a «ecoloxía da paisaxe» trata de explicar as relacións que se agachan na imaxe percibida polo observador. Esta imaxe é polisensorial (González Bernáldez, Sancho Royo e García Novo, 1973, p. 66-81; González Bernáldez, 1981), non só visual. Segundo iso, tan real sería a imaxe da paisaxe que recibe unha persoa cega como a que percibe outra que non o é, pero que carece de olfacto ou está xorda.

A paisaxe é un dos recursos naturais e culturais que sustentan a humanidade. $\mathrm{Na}$ actualidade, o valor e o interese da paisaxe semellan ter unha importancia crecente, tanto nas sociedades economicamente desenvolvidas como nas que non o están, e en xeral nas comunidades máis cultas, sexan urbanas ou rurais, de maneira que este concepto constitúe hoxe unha referencia habitual no mundo da ciencia, as humanidades, a técnica e a política. No contexto do «medio ambiente», a paisaxe é un compoñente que ten cada vez maior relevancia. 


\section{INCORPORACIÓN DA PAISAXE Á POLÍTICA AMBIENTAL}

En outubro de 2000, asinouse en Florencia o Convenio Europeo da Paisaxe. Desde aquela, é coñecido como Convenio de Florencia. O acordo foi asinado por trinta e cinco países europeos e no seu enunciado trataba de comprometer na conservación da paisaxe tanto ás administracións como ás sociedades europeas. Afirmaba o convenio que «a paisaxe é unha parte do territorio, tal como a perciben a poboación local e os visitantes, que cambia co tempo, como resultado de fenómenos naturais e inducidos polos seres humanos».

O Goberno español ratificou ese convenio en novembro de 2007 e comprometeuse a que entrase en vigor en marzo de 2008. Na peculiar linguaxe das declaracións institucionais, a Administración española indicaba que «os conceptos de patrimonio natural e cultural se fusionan por primeira vez nunha visión integral da paisaxe que contempla tanto os aspectos naturais como os culturais, introduce a dimensión social da paisaxe e outórgalle a consideración de elemento de benestar, dándolle cobertura á relación que se establece entre o ser humano e o medio en que habita».

Unha década antes da reunión de Florencia, en xuño de 1991, celebrárase no castelo de Dobris, preto de Praga, unha conferencia orientada a preparar un informe sobre a situación do medio natural en Europa. Nesta reunión constatábase a necesidade de dispoñer de datos e información axeitados para coñecer e formalizar os problemas ambientais comúns no territorio europeo. Así, poderíanse resolver, sobre esta base, os que esencialmente eran, e seguen a ser hoxe, os problemas derivados do desenvolvemento radical perseguido de facto pola sociedade europea do benestar: o seu alto consumo de recursos naturais, particularmente de enerxía, a xeración de refugallos e a perigosa forma de ocupación do territorio levados a cabo na historia recente.

O Informe Dobris (Stanners e Bourdeau, 1991) partía dunha descrición das características xerais do continente europeo e, entre os compoñentes e problemas considerados para a avaliación ambiental -aire, augas continentais e mariñas, vida silvestre, consumo, contaminación, etc.- atopábase por primeira vez unha descrición territorial de Europa no tocante á súa "paisaxe». Era unha relación preliminar, pero sistemática, que as administracións europeas non estaban afeitas aínda a ver reflectida dentro da temática medioambiental. 
A paisaxe, considerada como un recurso baixo as perspectivas xeográfica, ecolóxica, psicolóxica ou artística, pasaba a constituír un elemento de referencia obrigada para a administración ambiental europea. Parece sensato que o ambiente -o medio, o contorno, o que rodea ao ser humano- non poida, en efecto, entenderse só a través da súa análise ou descomposición en partes ou atributos temáticos estudados por diferentes especialistas, senón que debe concibirse e valorarse tamén como un conxunto unitario, tal como é percibido pola xente. A idea de paisaxe contribúe, en boa parte, á comprensión sistemática e sistémica do medio natural e pode axudar a canalizar eficazmente a toma de decisións sobre a ocupación do territorio e o uso dos recursos naturais.

\section{CONCEPCIÓN ECOLÓXICA DA PAISAXE}

A Ecoloxía é a ciencia do medio natural. A raíz grega da palabra, oikos, significa casa e facenda -o ambiente físico no que se refuxia a vida e do que depende a economía dos seres que alí habitan. Pode dicirse que a Ecoloxía non é necesariamente unha rama da Bioloxía, ou polo menos que forma parte desta ciencia tanto como da Física.

A ciencia ecolóxica focalizou a idea de "paisaxe» fixando tres puntos de vista que son propios da Xeografía, o territorio; da Psicoloxía, a percepción da imaxe; e a mesma Ciencia ecolóxica, as tramas de relacións físicas, biolóxicas e culturais que compoñen a paisaxe. A expresión «ecoloxía da paisaxe» é relativamente recente (Troll, 1939, p. 241-298), tivo un grande éxito e presenta hoxe múltiples acepcións máis ou menos científicas, a meirande parte moi populares.

Esencialmente, a ecoloxía da paisaxe debería ter en conta os puntos de vista da teoría ecolóxica -termodinámicos, xeofísicos, xeoquímicos, fisiolóxicos, demográficos, biocenóticos, derivados de interaccións biolóxicas- e tería que prestarlle moita atención á relación entre o medio natural e a sociedade humana. A meirande parte dos estudosos das diferentes acepcións da expresión «ecoloxía da paisaxe» están particularmente interesados nisto último. 


\section{Territorio}

O territorio é a expresión do espazo sobre a superficie sólida dos continentes. R. Margalef (1975) di que «vivimos no fondo dun océano de aire». Precisamos un substrato sólido -o terreo- cando tomamos conciencia do territorio. Fálase de territorio costeiro, pero non se ten sentido de territorio, ou non se aplica a idea, cando se está no medio do mar (Díaz Pineda, 2003, p. 181-198). A interpretación do territorio pode revestir tanto matices xeográficos físicos -cartesianos, topolóxicos, topográficos, climáticos, xeomorfolóxicos, edáficos, hidroxeolóxicos-, como bioxeográficos -xeobotánicos, zooxeográficos- ou culturais -«función» que cumpre o territorio para a sociedade humana, formas de ocupación, explotación e usos humanos do espazo. Todos eles, non obstante, adoitan centrarse nun concepto unitario: o territorio obedece máis a unha síntese interpretativa do espazo que á súa análise ou descomposición en partes, e o seu aspecto considérase habitualmente como paisaxe.

González Bernáldez (1981) insiste nesta interpretación unitaria do territorio a través da súa análise previa. Para iso, o estudo e a descrición ecolóxica da paisaxe, segundo unha perspectiva espacial -territorial-, poderían partir da cuantificación de compoñentes temáticos do espazo; por exemplo, os atributos climáticos, litolóxicos e sedimentolóxicos, estrutura xeolóxica e idade dos materiais, topografía, dinámica xeoquímica e hidrolóxica, hidroxeoloxía, edafoloxía, vexetación, fauna, biocenose microbiana e tipoloxía dos compoñentes culturais rurais e tecnolóxicos.

Pero a síntese desta serie de características non debe consistir nunha mera relación capitular ou nunha xustaposición. Con frecuencia, a aplicación dos sistemas de información xeográfica (XIS) está enfocada cara á descrición ambiental do territorio, con base na mera superposición de «capas» temáticas. Esta superposición non adoita explotar outra relación entre esas capas que a concorrencia porcentual de diferentes tipos de superficies para delimitar unidades mixtas ou «sectores ambientais» e cousas así. Esta actividade, que supuxo unha novidade metodolóxica hai xa máis de tres décadas (Gómez-Orea, Díaz-Pineda et al., 1975), carece aínda, mesmo en estudos autodenominados de ecoloxía da paisaxe, da procura de factores e procesos ecolóxicos que expliquen a funcionalidade da paisaxe como sistema e a estrutura resultante desta funcionalidade. 
Algúns autores chamaron a atención sobre a condición de «sistema espacial» que ten o territorio e resaltaron a importancia dos fenómenos físicos -«xeosistema»- que conectan entre si porcións do espazo que poden aparecer contiguas ou estar moi afastadas entre si (Solntsiev, 1974; Fortescue, 1980). Outros interesáronse por describilo como un "tecido", nun sentido semellante ao que lle dan os biólogos e médicos á palabra (González Bernáldez, 1981; Díaz Pineda e Schmitz, 2003, p. 9-28), aplicándolles unha idea, en certa forma fisiolóxica, ás conexións ecolóxicas espaciais do territorio.

As tramas de relacións mencionadas explican as propiedades emerxentes dos sistemas que compoñen a paisaxe. Estas tramas existen «dentro» de sistemas que poderían delimitarse de xeito máis ou menos arbitrario e tamén se prolongan «entre» estes sistemas -é a idea orixinal de «conectividade». A teoría ecolóxica hai tempo que se ocupou de formalizar estes conceptos sobre a base dos fenómenos físicos e os procesos biolóxicos que explican a estabilidade dos sistemas ecolóxicos (Leigh, 1965, p. 777-783; Margalef, 1969, p. 25-37; May, 1973; Orians, 1975, p. 174-189).

$\mathrm{Na}$ actualidade, estas consideracións verbo do territorio-paisaxe semella que se canalizaron cara ao campo da explotación dos recursos naturais. Isto xustifícase pola preocupación propia dunha poboación humana en crecemento demográfico exponencial e, máis aínda, cun aumento formidable do consumo enerxético e da ocupación industrial e urbana do territorio. Así, os recursos naturais -o espazo e a paisaxe entre eles- poden ser considerados como sustentos materiais canalizados polo mercado -alimentos, materias primas, enerxía- e tamén como valores menos tanxibles denominados «bens e servizos ecosistémicos» -conservación do ciclo hidrolóxico, depuración da auga, a propia paisaxe, etc. (Cairns e Pratt, 1995, p. 273-294; Costanza e Folke, 1997; Costanza et al., 1997).

\section{Percepción da imaxe}

Co concepto de sistema in mente, xusto no mesmo sentido que lle dan os físicos a esa idea, a paisaxe sería un «fenosistema», palabra empregada por González Bernáldez (1981) por analoxía co concepto biolóxico de fenotipo. O fenosistema é a imaxe que percibe un observador cos seus sentidos. Baixo esta 


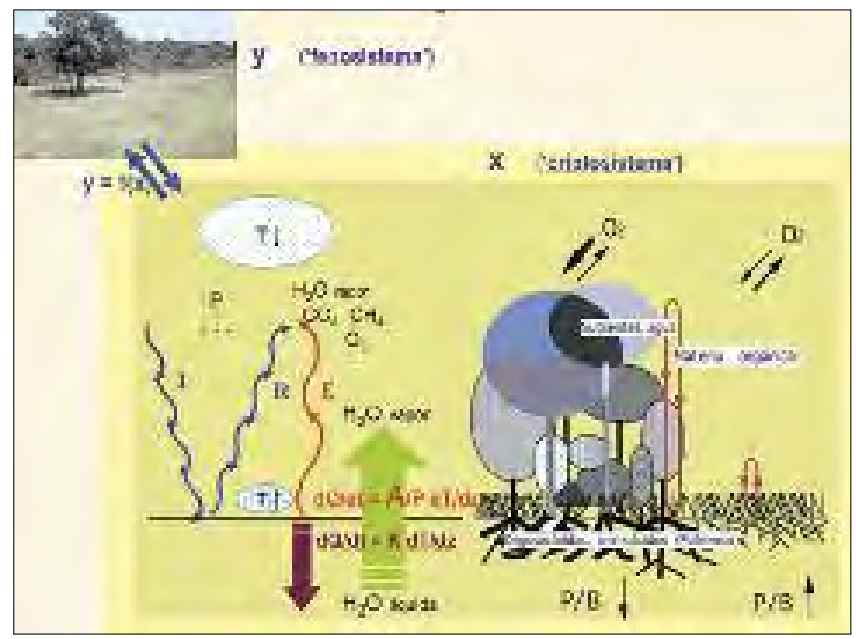

A paisaxe como criptosistema na ecoloxía contemporánea

aparencia, existen fenómenos físicos e procesos ecolóxicos de cuxo funcionamento xorde esa imaxe. Estes fenómenos e procesos, entre os que se atopan as actividades culturais, poden ser, en boa medida imperceptibles -a acidez do solo, a composición química da rocha, a auga ou o aire, a presión atmosférica, a composición química do aire, a produción de oxíxeno dun prado, a natalidade dunha poboación de toupiños-, pero poden dilucidarse coa axuda de medidas e cálculos axeitados. Constitúen o substrato da paisaxe oculta aos sentidos ou "criptosistema», como o xenotipo é a parte oculta aos sentidos do fenotipo dun individuo.

A ecoloxía da paisaxe pretende pois, por unha banda, analizar e formalizar os procesos subxacentes como criptosistema e, por outra, caracterizar a imaxe que estes xeran. Para esta caracterización, os ecólogos recorreron a aproximacións psicolóxicas, mediante o estudo das apreciacións, preferencias e valoracións dos observadores ou «usuarios» da paisaxe. A valoración da paisaxe a través das súas características estéticas ou emocionais resultou de grande interese mutuo, tanto para a saúde humana e o seu gozo da natureza -pero tendo presente a dificultade dunha valoración obxectiva e por consenso (Lowenthal, 1978, p. 373-418; González Bernáldez, 1981)-, como para a conservación da natureza e a propia paisaxe -xestión ambiental do territorio. Desenvolvéronse un número notable 
de procedementos para valorar a paisaxe de xeito independente dos seus usuarios -habitantes do lugar e visitantes máis ou menos ocasionais- e baseados nas preferencias destes, así como métodos mixtos (González Bernáldez, 1981; Schmitz et al., 2004, p. 307-317; Schmitz et al., 2006, p. 139-148; Schmitz et al., 2007, p. 300-312), todos eles con maior ou menor aceptación, dependendo do problema proposto e o seu contexto.

\section{Tramas de relacións: conectividade «horizontal»}

A Ecoloxía está precisamente dedicada ao estudo de tramas de relacións biofísicas. Boa parte da dinámica destas tramas responde a fenómenos físicos ou fisicoquímicos nos que apenas participa a vida. Así, a radiación solar explica o quentamento do solo e este, o do aire, a evaporación da auga, a dinámica atmosférica e os fenómenos asociados. As tramas da vida engádenlles a estes fenómenos outros bioquímicos: a radiación permite a vida das plantas a través de procesos de redución-oxidación. Estes procesos fan que flúan a materia e a enerxía na biosfera, a parte viva do planeta, e que circulen os elementos químicos entre medio físico e biótico. A propia vida é un proceso continuo de transformación enerxética.

Xunto a estes fenómenos acontecen outros de transferencia de materia e enerxía que transcorren no territorio de xeito claramente horizontal e que explican a devandita interpretación deste como un tecido. A paisaxe resultaría en boa medida do funcionamento deste tecido, que constituiría un conxunto de «infraestruturas ecolóxicas» que conectan unhas porcións territoriais con outras, en certa medida de forma semellante á rede de infraestruturas humanas de transporte.

As conexións físicas explícanse en boa parte só coa circulación da auga. $\mathrm{O}$ terreo está sempre modelado, formando ladeiras, grandes ou pequenas, máis ou menos empinadas, dependendo moito da escala á que se aprecie. É difícil atopar un terreo absolutamente plano, mesmo camiñando por un campo de fútbol. A través das ladeiras ocorren fenómenos de infiltración de auga, circulación subsuperficial e humectación acentuada das zonas baixas. Procesos de erosión, transporte de materiais e acumulación nestas zonas acompañan aqueles fenómenos. As ladeiras terminan por constituír concas hidrográficas de orde crecen- 
te, drenadas por regatos temporais ou permanentes e ríos. Os esteiros reciben unha boa cantidade de substancias disolvidas e en suspensión que complican as tramas ecolóxicas mariñas.

Ademais deste tipo de fenómenos físicos, ocorren outros en que participa a vida de forma máis destacada. O territorio adoita ser un mosaico -tamén depende da escala á que se aprecie-, un parcheado de pezas onde a masa viva e morta -herba, madeira, manto do solo, etc.- varía dunhas porcións a outras. Entre elas poden tamén apreciarse fronteiras netas de separación entre acumulacións desas masas: a fraga e a pradaría veciña constitúen un bo exemplo disto. Nestas fronteiras danse tensións enerxéticas máis ou menos acusadas. Os animais adoitan moverse dun lado a outro das fronteiras, transportando materia coa súa alimentación e excreción. As aguias aniñan na fraga, pero aliméntanse de coellos que comen na pradaría. Os cervos comen máis na pradaría que na fraga, onde se refuxian coas súas crías. Forman (1983, p. 375-387) considera que a ecoloxía da paisaxe debe ter en conta os fluxos de enerxía, materia e organismos vivos entre «elementos da paisaxe» -que chama «ecosistemas» e chega a delimitar no espazo territorial- e a dinámica que caracteriza o «mosaico paisaxístico» a través do tempo.

No territorio son, polo xeral, moi notables os «corredores biolóxicos». Pode tratarse de estruturas lineais que cumpren sobre todo unha función de refuxio para organismos silvestres de todo tipo -as sebes nas paisaxes de bocage, certas estruturas riparias, cadeas montañosas difíciles de transitar polos humanos-, pero con maior frecuencia estes corredores responden a estruturas laminares, por máis que queira entenderse a mobilidade animal con ollos de enxeñeiro de camiños ou coa perspectiva dun excursionista.

As propias estruturas e dinámicas agrarias contribúen moito á conectividade nas paisaxes culturais. Os reticulados de soutos, sebes, ribazos e lindes, como as trasfegas cotiás ou os transhumantes de vehículos, animais e campesiños manteñen redes vivas de transporte de moitos compoñentes físicos e biolóxicos. O territorio é un tecido e a súa conectividade pode formalizarse mediante numerosos fenómenos como os descritos (Forman et al., 2003; Pineda et al., 2006, p. 3-18). 


\section{TRAMA «PAISAXE CULTURAL-SOCIOECONOMÍA»}

A relación entre a estrutura e o funcionamento da paisaxe coa sociedade humana ofrece unha forma de interconexión que pode entenderse como «conectividade vertical», é dicir, a relación entre o plano que caracteriza o territorio e o que lle corresponde á estrutura socioeconómica (Schmitz et al., 2003, p. 343-356; Aranzábal et al., 2008, p. 672-685).

A paisaxe, en efecto, pode comprenderse e explicarse en boa medida como unha consecuencia da actividade humana. Toda a paisaxe planetaria ten actualmente un fortísimo compoñente cultural con raíces históricas máis ou menos acusadas. É curioso que, particularmente en Europa, as paisaxes agrarias -agrícolas, gandeiras, agropecuarias, forestais, silvopastorais- e industriais experimentaran na historia recente unha intensa transformación, directamente asociada a cambios sociais tamén intensos (Aranzábal et al., 2008, p. 672-685; Nikodemus et al., 2005, p. 57-67).

Unha comarca imaxinaria na que a totalidade dos seus habitantes fosen pastores -non existirían agricultores, leñadores, enxeñeiros, carpinteiros, etc.mostraría unha paisaxe que necesariamente sería a dun pasteiro. $\mathrm{O}$ mesmo ocorrería nunha comunidade exclusiva de leñadores e enxeñeiros forestais -unha fraga- ou nunha sociedade exclusiva de agricultores - un terreo cultivado-. En realidade, calquera comunidade humana ten unha estrutura socioeconómica diversa e o espazo comarcal onde habita, tamén, e mostran así un territorio heteroxéneo, máis ou menos complexo, condicionado por factores físicos e culturais. A análise numérica da correspondencia entre a paisaxe cultural e a estrutura socioeconómica ofrece interesantes posibilidades para descubrir os compoñentes da actividade humana máis relevantes na explicación do espazo territorial e da función da paisaxe. Trátase dunha relación vertical, mantida entre co-evolving systems (Norgaard, 1984, p. 160-173; Lacitignola et al., 2007, p. 191-204) -unha e outra estrutura- que pode converterse en modelo e usarse como referencia para presentar tendencias nos escenarios de cambio (Schmitz et al., 2003, p. 343-356; Aranzábal et al., 2008, p. 672-685). Nas políticas de conservación da paisaxe nas que se comprometeron formalmente as administracións europeas precísanse modelos sobre os que ensaiar escenarios de cambio. 
A paisaxe é un recurso importante. O cambio estase a producir vertixinosamente e non só en Europa. Non é variable dependente a paisaxe e a independente a sociedade, senón que, segundo as circunstancias, pode acontecer o contrario. A preocupación polo cambio climático está hoxe de rabiosa actualidade, potenciada por todo tipo de comunicados que anuncian a catástrofe. Ten o mérito de unir a todas as nacións na idea de que o desenvolvemento económico sen límites quizais non sexa a única vía da sociedade do benestar (Pineda et al., 1996). Non cabe moita dúbida de que o clima cambia e que o fai agora cunha maior velocidade que ata hai pouco, ou é que se ten máis información que antes, pero o cambio do planeta é global. Non implica só ao clima nin as solucións deben orientarse só con esta perspectiva. O cambio é estrutural, socioeconómico, cultural, e a referencia da paisaxe é necesaria nos escenarios para fundamentar a acción. 


\section{BIBLIOGRAFÍA}

ARANZÁBAL, I. et al:: «Modelling of lanscape changes derived from the dynamics of socio-ecological systems. A case of study in a semiarid Mediterranean landscape», Ecological Indicators, 8, 2008, p. 672-685.

CAIRnS, J. J. e J. R. PRATT: «The relationships between ecosystem health and delivery of ecosystem services», en D. J. RAPPORT, C. GAUDET e P. CALOW (ed.): Evaluating and monitoring the heath of large-scale ecosystems, Springer-Verlag, Heidelberg, 1995, p. 273-294.

Costanza, R. e C. FolKe: «Valuing Ecosystem Services with Efficiency, Fairness and Sustainability as Goals», en G. C. DALY (ed.): Naturés services: societal dependence on natural ecosystems, Island Press, Washington, 1997.

COSTANZA, R. et al:: «The value of the world's ecosystems services and natural capital», Nature, 387, 1997, p. 253-260.

Díaz Pineda, F.: «Paisaje y territorio», en C. García-Orcoyen (ed.): Mediterráneo y Medio Ambiente, Mediterráneo Económico, 4, Instituto de Estudios CajaMar, Almería, 2003, p. 181-198.

DíAz PinedA, F. e M. F. SCHMITZ: «Tramas espaciales del paisaje. Conceptos, aplicabilidad y temas urgentes para la planificación territorial», en R. GARCÍA MORA (coord.): Conectividad Ambiental: las áreas protegidas en la Cuenca Mediterránea, Junta de Andalucía, Sevilla, 2003, p. 9-28.

FORMAN, R. T. T.: «Corridors in landscape: their ecological structure and function», Ekologia (CSSR), 2, 1983, p. 375-387.

Forman, R. T. T. et al.: Road ecology. Science and Solutions, Island Press, London, 2003.

ForTeSCUE, J. A. C.: Environmental Geochemistry, Springer Verlag, Berlin, 1980.

Gómez-Orea, D. et al:: Plan Especial de Protección del Medio Físico en la Provincia de Madrid, ICONA, COPLACO, Ministerio Obras Públicas y Urbanismo, Madrid, 1975, 200 p., 2 mapas.

GonzÁlez Bernáldez, F., F. SANCho Royo e F. García Novo: «Analyse des réactions face au paysage naturel», Options Méditerranéennes, 17, 1973, p. 66-81.

GonZÁlez BernáldeZ, F.: Ecología y paisaje, Blume, Madrid, 1981.

LACITIGNOLA, D. et al.: «Modelling socio-ecological tourismo-based systems for sustainability», Ecological Modelling, 206, 2007, p. 191-204.

LEIGH, E. G.: "On the relationship between productivity, biomass, diversity and stability of a community», Proc. Nat. Acad. Sci. 53, 1965, p. 777-783.

Lowenthal, D.: «Finding valued landscapes», Progress in Human Geography, 2, 1978, p. 373-418.

MARGALEF, R.: «Diversity and stability: A practical proposal and model of interdependence. Brookhaven Nat. Lab.», Springfield. V Symp. Biol. 22, 1969, p. 25-37.

MARGALEF, R.: Ecología, Omega, Barcelona, 1975.

MaY, R. M.: Stability and Complexity in Model Ecosystems, Princeton Univ. Press, Princeton, 1973.

NiKodEmUS, O. et al.: «The impact of economic, social and politic factors on the landscape structure of the Vidzeme Uplands in Latvia», Landscape and Urban Planning, 70 (1/2), 2005, p. 57-67.

NorgaARD, R. B.: «Coevolutionary development potencial», Land Economy, 60 (2), 1984, p. 160-173.

ORIANS, G. H.: «Diversidad, estabilidad y madurez de los ecosistemas naturales», en W. H. van DobBEN, e R. H. Lowe-McConnell (ed.): Conceptos unificadores en ecología, Blume, Barcelona, 1975, p. 174-189.

PINEDA, F. D. et al:: Ecología y desarrollo. Escalas y problemas de la dialéctica Desarrollo-Medio Ambiente, Editorial Complutense, Madrid, 1996.

PINEDA, F. D. et al.: «Conectividad territorial. Procesos horizontales del paisaje e interferencias del transporte humano", Revista Carreteras, 20, 2006, p. 3-18. 
SCHMiTZ, M. F. et al:: «Relationship between landscape typology and socioeconomic structure. Scenarios of change in Spanish cultural landscapes», Ecological Modelling, 168, 2003, p. 343-356.

SCHMITZ, M. F. et al.: «Visitor's valuation of natural and cultural landscapes: space-preferences coincidence analysis», en F. D. Pineda e C. A. BrebBiA (ed.): Sustainable tourism, Witt Press, Boston, 2004, p. 307-317.

SCHMITZ, M. F. et al.: «Participation of visitors in the management design of protected natural areas», WIT Transactions on Ecology and the Environment, 97, 2006, p. 139-148.

SCHMitZ, M. F., I. ARANZÁBAL e F. D. PINEDA: «Spatial analysis of visitor preferences in the outdoor recreational niche of Mediterranean cultural landscapes», Environmental Conservation, 34 (4), 2007, p. 300-312.

SOLNTSIEV, V. N.: «O niekotorikn fundamentalnykh svoistakh gheosistemnoi struktury», Methody kompleksnykh issledovanii gheosistem, Akademya Nauk SSSR, Irkutsk, 1974.

Stanners, D. e P. Bourdeau: Medio Ambiente en Europa. El Informe Dobris, Oficina de Publicaciones Oficiales de las Comunidades Europeas, Ministerio de Medio Ambiente, Madrid, 1991.

Troll, C.: "Luftbildplan und okologische Bodenforchung», Zeistschraft der Gesellschaft fur Erdkunde zu Berlin, 1939, p. 241-298. 
Retruque

SOBRE A PAISAXE GALEGA.

REFLEXIÓNS DESDE A

ECOLOXÍA DA PAISAXE

Carlos Vales

Centro de Extensión Universitaria e Divulgación Ambiental de Galicia 

Os intérpretes iniciais da paisaxe -das paisaxes- galega non proveñen das Ciencias naturais, senón da Xeografía e das Ciencias humanas e as súas apreciacións non son entendibles sen a concepción subxectiva do territorio. Conceptos marabillosos como o de ribeira e bocarribeira de Otero Pedrayo (1955) son inconcibibles sen a evidencia de como ese territorio é usado, reflicten a utilización antrópica do medio. Felizmente, nas últimas décadas lévanse feito achegas para entender as paisaxes e, o que é máis importante, o seu funcionamento e valor como soporte do funcionamento viable a longo prazo das sociedades humanas que as usan, crean e recrean, desde outros ámbitos científicos confluentes (Burel e Baudry, 2001). Neste traballo exploraremos brevemente as achegas que desde o ámbito das Ciencias da natureza e, en particular, a Ecoloxía se poden facer para realizar unha interpretación intelectual da paisaxe, así como a conservación e xestión das máis relevantes e dos seus elementos máis valiosos. Destacaría o carácter necesariamente confluente das distintas achegas, porque existe un debate sobre o carácter da paisaxe e da disciplina ou disciplinas que permiten unha aproximación ao seu entendemento. Non pretendo aquí competir polo obxecto de estudo -a paisaxe-, como patrimonio dun ámbito de coñecemento determinado porque as aproximacións son, e deben ser, necesariamente múltiples. En calquera caso, ese conflito realmente existente sobre definicións e campos de coñecemento reflicte a existencia dun marco conceptual aínda inmaturo nas súas definicións e terminoloxía, así como a falta de entendemento desde algúns ámbitos de que a complexidade dos desafíos ambientais -e a paisaxe é un compoñente fundamental do ambiente- non pode ser encarada desde disciplinas compartimentadas, senón que precisa de formulacións transdisciplinares (Leff, 2005; e Wu e Hobbs, 2007).

Unha paisaxe é, certamente, unha creación cultural, cando menos no concepto europeo da palabra (Nogué, 2007), porque implica a percepción social do territorio visualizado. Ten que ver cun sentimento antropocéntrico, cultural e, 
por certo, como moi ben sinala Alain Roger (2007), non necesariamente compartido e comprendido por todos os seres humanos. Mais non comparto con Roger a pretensión de que a paisaxe só pode ser interpretada dun xeito subxectivo e afirmo, pola contra, que é preciso e útil o intento de obxectivación dos seus valores. Expresareino a través dun exemplo: a conservación da natureza salvaxe africana foi unha necesidade sentida por certos colectivos das sociedades occidentais, mentres que o gran poeta africano Shengor, que foi presidente do Senegal, afirmaba que os occidentais tiñan unha estraña necesidade compulsiva de ver leóns. Culturalmente, as percepcións duns e dos outros -africanos e europeos- sobre os leóns non comparten nada, porque mentres que a uns lles comen as cabras, para os outros representan a recreación do mito do mundo salvaxe, do paraíso orixinal. Aquí, o desexo de conservar leóns é occidental, o cal non obsta para que a conservación dos leóns, e do que eles significan no tocante á saúde do ecosistema, sexa obxectivamente boa, pertinente, necesaria. Non é unha suposta e inexistente superioridade da percepción cultural occidental o que xustifica a conservación das paisaxes que fan viable a existencia dos leóns, senón o propio benestar das comunidades locais a longo prazo, asentado na saúde deses ecosistemas. Así, a conservación e xestión da paisaxe enlaza coa xestión e conservación da biodiversidade. A importancia asignada á conservación da biodiversidade é unha decisión humana, pero baseada nun coñecemento científico sólido. Como afirma Edward Wilson (2002), probablemente o que nunca lle perdoarán as xeracións futuras á actual é que actuara con tanta estulticia na conservación dos recursos biolóxicos da Terra.

E que ten que ver a paisaxe coa conservación da biodiversidade? Entre outras cousas, que a paisaxe é unha das maneiras en que esta biodiversidade se expresa. A paisaxe é un dos niveis en que se manifesta a diversidade biolóxica, ou biodiversidade, un concepto certamente tan amplo e difuso que, malia o seu éxito popular como vocábulo totalizador, non conseguiu aglutinar ao seu redor as paixóns sociais necesarias como para convertelo nunha referencia simbólica indiscutible da crise ambiental da nosa época, aínda que a estamos a degradar de maneira irreparable e con resultados devastadores. O Convenio sobre a Diversidade Biolóxica defínea como "a variabilidade de organismos vivos de calquera fonte, incluídos, entre outras cousas, os ecosistemas terrestres e mariños e outros ecosistemas acuáticos e os complexos ecolóxicos dos que 
forman parte»; comprende a diversidade dentro de cada especie, entre as especies e dos ecosistemas. É mágoa, na miña opinión, que a definición de biodiversidade asumida polo Convenio de Diversidade Biolóxica non inclúa unha referencia explícita á paisaxe, no canto de falar de «complexos ecolóxicos», conceptos que poderían ser intercambiables, sempre que se dese o consenso científico pertinente. Porque a paisaxe -as paisaxes- é un nivel de organización intermedio entre o ecosistema concreto e a biosfera como conxunto. E a súa análise é imprescindible para entender como funciona o mundo biolóxico, como funciona Gaia. Desde a biodiversidade, a paisaxe é o conxunto de ecosistemas -ou "hábitats», en terminoloxía menos precisa pero de maior divulgación- que existen sobre un territorio determinado, a súa extensión relativa, o tamaño dos seus fragmentos e a súa distribución espacial. Estas matizacións da definición, que nunha ollada superficial poden parecer intranscendentes, teñen unha enorme relevancia no mundo real. Unha paisaxe que comparta exactamente o mesmo tipo de hábitats con outra pode ter unhas propiedades totalmente diferentes ás desta última, simplemente polo tamaño e a disposición xeográfica dos ecosistemas que contén. Estas propiedades significan, entre outras cousas, unha determinada capacidade para conter biodiversidade e para sustentala ao longo do tempo. Isto é así porque para que unha determinada especie poida existir non abonda coa existencia do hábitat ou dos hábitats necesarios para sustentala, senón que é preciso que estes teñan suficiente extensión como para permitir a existencia de poboacións viables, ou que os fragmentos de hábitat estean o suficientemente próximos como para posibilitar a circulación entre os diferentes fragmentos, ou que existan corredores capaces de posibilitar ou facilitar os desprazamentos. Tamaño, forma e patrón de distribución territorial dos distintos tipos de hábitat sobre un territorio determinado permiten identificar as propiedades dese territorio e as calidades da armazón viva que sustenta. A importancia conceptual destas análises foi establecida de maneira sistemática a partir do traballo seminal de R. T. T. Forman e M. Godron Landscape Ecology, publicado en 1986, aínda que os antecedentes poden atoparse na propia orixe da ecoloxía da paisaxe establecida polo xeógrafo alemán Carl Troll en 1939, fusionando o concepto de ecosistema do británico A. Tansley, en 1935, co patrón territorial que ofrecían as fotografías aéreas sobre as paisaxes europeas. 
Que achega esta aproximación á análise da paisaxe? Penso que moitas cousas que axudan á súa mellor comprensión e xestión. Centrareime en tres exemplos desa utilidade. Así, a ecoloxía da paisaxe axuda a entender cales son os elementos máis valiosos das nosas paisaxes tradicionais, achegándonos criterios para definir a dirección dos esforzos para a súa conservación. Tamén nos axuda a interpretar os cambios paisaxísticos en marcha, facer predicións sobre as súas consecuencias e tomar decisións de planificación e xestión paisaxística sobre bases conceptuais minimamente sólidas. Permítenos, en fin, ampliar o noso propio criterio do que é a paisaxe, en beneficio dunha mellor xestión do noso contorno. Centrándonos nas nosas paisaxes tradicionais, debe ser destacada a súa orixe antrópica e a súa profunda fragmentación. Son espazos onde a campiña agraria e as manchas forestais, xunto coas landas e os brañais nas súas diferentes tipoloxías, sexan de augas correntes ou estancadas, constitúen a armazón central da meirande parte das paisaxes históricas galegas. Sen negar o valor indiscutible dos hábitats de monte nas súas diferentes tipoloxías, e dos brañais, os datos científicos dispoñibles amosan que a campiña agraria e o bosque autóctono son claves como garantes da calidade de hábitat e da relevancia da biodiversidade dentro dos hábitats terrestres galaicos. É certo que esta afirmación está fundamentalmente baseada na utilización de aves como indicadores de calidade de hábitat (Bongiorno, 1982), pero outras análises, baseadas noutros grupos de organismos, coinciden na valoración (Fernández Vidal, 1991). Tamén sabemos que o tamaño dos hábitats, a súa extensión relativa e patrón de distribución, é fundamental para a súa calidade como reservas de biodiversidade, que a importancia da campiña agraria radica na súa elevadísima diversidade estrutural e que os bosques máis grandes e maduros son os máis valiosos (Lindenmayer e Franklin, 2002). Só con estes datos na man, a conservación das paisaxes agrarias e dos bosques autóctonos de maior tamaño a elas asociados debería ser prioritaria. É evidente que isto non acontece na xestión global do territorio, posto que se seguen a destruír eses elementos da paisaxe con base en políticas de suposto desenvolvemento económico, como as representadas de modo paradigmático pola concentración parcelaria na comarca da Limia, aínda que non é o único exemplo. É certo que a conservación desas paisaxes presenta dificultades obxectivas, dados os procesos de transformación en curso no mundo rural, o que significa ter que facerlles fronte a desafíos de enorme envergadura, como conservar 
as paisaxes históricas, xunto coas estruturas que as fan valiosas. E as estruturas só poderán sobrevivir se teñen unha función (Mandianes, 1992). En calquera caso, a ecoloxía da paisaxe subminístranos argumentos adicionais para conservar un patrimonio paisaxístico que non só ten un valor como espazo natural, senón tamén histórico e moral, e achéganos unha bagaxe conceptual que axuda a identificar prioridades de conservación e xestión paisaxística.

Un segundo exemplo da utilidade da aproximación que aquí acometemos é que a ecoloxía da paisaxe permite interpretar as transformacións que están a acontecer nas paisaxes galegas e predicir as súas consecuencias, ademais de subministrar ferramentas teóricas para orientar as tomas de decisión diante deses cambios que están a acontecer de maneira vertixinosa, posto que nun período temporal de décadas estanse a producir transformacións que noutros países aconteceron durante séculos e que inclúen, nos seus principais trazos, a transformación dos antigos montes desde espazos abertos a plantacións de eucaliptos e piñeiros, a reforestación de terras agrarias, a desecación de brañais, a urbanización do litoral, así como das contornas das cidades históricas, e a multiplicación das infraestruturas que fan o territorio máis artificial. Os cambios nos usos da terra aféctanlles ao funcionamento dos ecosistemas, á súa capacidade de automanterse, á calidade de hábitats dispoñibles, ás capacidades de dispersión e migración vitais para a supervivencia das poboacións e, en definitiva, á capacidade de carga biolóxica da paisaxe, polo que tanto o proceso como as previsións das súas consecuencias deberían ser estudadas con detemento. Especial relevancia ten o proceso de urbanización en curso, un acontecemento que non é exclusivo de Galicia (AEMA, 2006), que leva consigo, como fenómenos complementarios, a concentración da poboación no litoral e o despoboamento do rural. Así, a paisaxe resultante ten un novo xeito de fragmentación, baseado nunha nova diversidade de elementos artificiais que asocian maior fragmentación con homoxeneización paisaxística, posto que os novos elementos son pouco útiles para a diversidade da vida. Como resultado, prodúcese o fenómeno, aparentemente contraditorio, de que o despoboamento rural non aumenta, senón que diminúe a calidade e diversidade dos hábitats dispoñibles, debido a que a diversidade estrutural se reduce drasticamente e as interconexións naturais diminúen, como poñen de manifesto, por exemplo, a degradación dos ríos e das súas ripisilvas asociadas. En consecuencia, rescatar a calidade da paisaxe e a súa capacidade de prestar servizos ambientais supón recuperar a súa multi- 
funcionalidade e a súa coherencia, e implica novas maneiras de enfrontarse ao fenómeno urbano (Newman e Jennings, 2008) e a necesidade de incrementar a calidade ambiental destes novos espazos (Hough, 1995; e Weather, 1999), así como acometer a presenza de contornos renaturalizados (Carreiro et al., 2008), o que, tamén é interesante sinalalo, lle abre o campo a disciplinas emerxentes (Clewell e Aronson, 2007). En calquera caso, o desafío último consiste en tentar recuperar a coherencia ecolóxica da paisaxe, aplicando o coñecemento científico existente e, tamén, inevitablemente, aprendendo da práctica.

Por fin, unha terceira consideración é que a ecoloxía da paisaxe nos subministra argumentos e ferramentas para incorporarlle ao noso patrimonio paisaxístico colectivo un novo territorio, o mariño. De entrada, o mar non é paisaxe, no sentido canónico da palabra, porque o concepto de paisaxe implica a percepción de referentes físicos que no mar non existen, só está presente a lámina de auga animada polos axentes meteorolóxicos. Pero cando estou a falar de incorporar o territorio mariño ao noso catálogo de paisaxes identitarias, non me refiro á superficie de auga, senón ao fondo do mar. Os fondos mariños son, sen dúbida, paisaxe no sentido ecolóxico da palabra, como ensamblaxe de ecosistemas diferentes nun territorio determinado (Wu e Hobss, 2007). Son, tamén, paisaxe na práctica cotiá e na bagaxe conceptual de colectivos expertos (Bridgewater, 2005). E, engado eu, precisamos que sexan paisaxe, no seu sentido de apropiación social pola comunidade responsable da súa conservación e da súa transformación en curso, fronte á evidencia de atoparnos diante dun territorio que precisa ser incluído con urxencia na axenda de preocupacións ambientais da humanidade (Glover e Earle, 2004). Probablemente, os fondos mariños aínda non son paisaxes á maneira en que un territorio é percibido pola comunidade que o usufrutúa e que inflúe na súa supervivencia e evolución, porque esa percepción aínda é incipiente. Pero tanto a tecnoloxía actualmente dispoñible, como a información que o público ten, e a evolución -tanto entre os especialistas como no conxunto do corpo social- na percepción de cales deben ser as prioridades na axenda da conservación da diversidade biolóxica están a poñer os fondos mariños baixo un foco de atención novo (Byatt et al., 2001). Digamos que, ata hai moi poucos anos, só concibiamos o mar desde a lámina de auga que ocultaba o descoñecido pero, na actualidade, tanto as tecnoloxías dispoñibles como a sensibilidade ambiental da sociedade e o coñecemento adquirido posibilitan que aspiremos a nos apropiar 
Nacemento do río Cabe, Macizo Central Ourensán

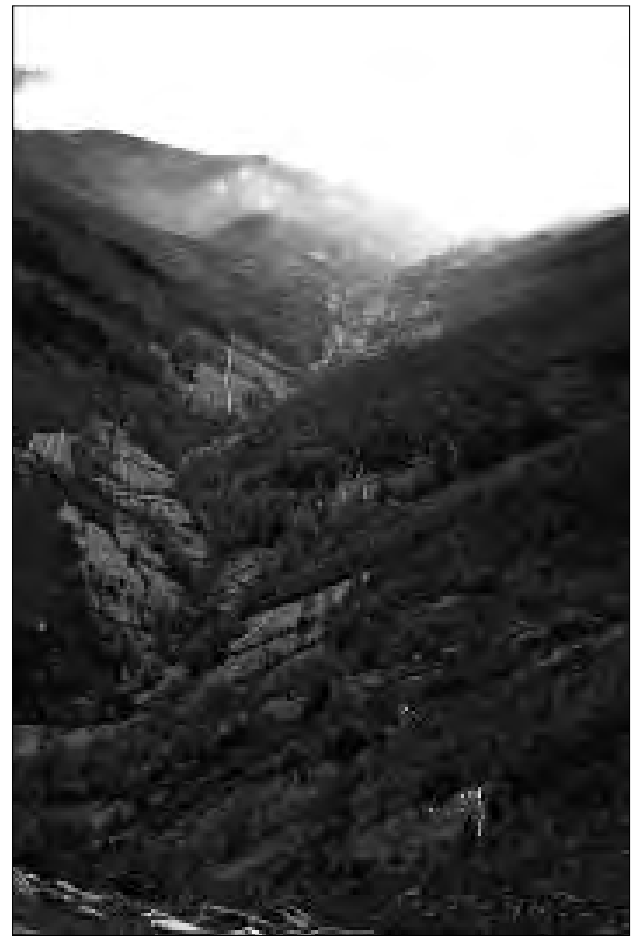

socialmente dese fascinante mundo de silencio, desde os campos de gorgonias aos bosques de algas, desde os bancos de area ás pradarías de fanerógamas. E non é preciso ser un mergullador para gozalos, porque os barcos con casco transparente xa arestora son utilizados para visitas turísticas nas rías, e os documentais de natureza para a televisión posibilitan facer visibles esas paisaxes submarinas para o conxunto da poboación, ademais de recoñecer a súa beleza, diversidade e riqueza biolóxica, así como as ameazas de degradación, os procesos de destrución e, xa que logo, a responsabilidade social sobre a súa conservación e xestión. Exactamente igual que acontece coas paisaxes terrestres.

Quero facer unhas últimas reflexións antes de rematar. A xestión da paisaxe presenta importantes desafíos nos ámbitos da investigación, capacitación e a educación. A estas alturas, nas que resulta evidente que a paisaxe non é só un elemento valioso que hai que conservar, senón un espazo onde se xoga o futuro da nosa calidade de vida, chama a atención a incapacidade do noso corpo intelectual colectivo para prestarlle a atención que merece. De feito, non deixa de 
sorprenderme a carencia de produción científica que avale a importancia da paisaxe rural, a falta de documentos que defendan, desde a perspectiva científica, a supervivencia da cultura e da paisaxe rural tradicional; a carencia de proxectos que fagan prospectiva das transformacións paisaxísticas en curso e que xeren propostas para garantir a nosa capacidade de contribuír á conservación da diversidade biolóxica europea, na cal a conectividade dos espazos naturais dentro do territorio é un elemento estratéxico, cando a ecoloxía da paisaxe xa ten demostrado a súa utilidade neste campo (Lepart et al., 2008). Gustaríame que fose de aplicación no noso caso a apreciación de Arts e outros autores: «during the last decade, the nature conservation policies in many European countries have been based on landscape-ecological research, especially concerning the role of land use and landscape structure in the survival of species and in the protection of nature reserves» (Jongman e Pungetti, 2004, p. 4), mais o certo é que nós, nesa altura, aínda andabamos a definir que territorios incluír nunha rede galega de espazos protexidos minimamente representativa e coherente. Pero, malia o noso atraso nese ámbito, a conservación da natureza en Europa evolucionou moito, desde a protección de lugares -os espazos naturais- cara á protección de redes ecolóxicas, incluíndo a paisaxe como un conxunto. É certo que, felizmente, non partimos de cero, que traballos como o Atlas de los Paisajes de España (Mata Olmo e Sanz Herráiz, 2003) sentan bases de partida que complementan o traballo realizado polos xeógrafos galegos sobre as nosas paisaxes, pero tamén resulta para min evidente que é preciso realizar pesquisas moito máis concretas e ambiciosas desde a perspectiva aquí defendida.

Outro traballo que cómpre acometer é o da diseminación, entendendo por tal a divulgación e posta a disposición dos potenciais usuarios da información científica dispoñible. Probablemente as actuacións máis determinantes sobre o futuro das nosas paisaxes van ser as dos técnicos e políticos que toman decisións que implican actuacións sobre o territorio, e só se estes son conscientes dos potenciais efectos das súas decisións poderemos evitar danos colaterais. Por outra banda, parte do noso coñecemento práctico -noso, en canto que suxeito colectivo- vai proceder da aprendizaxe na práctica, o que implica necesariamente a colaboración e posta en común entre científicos, técnicos e persoas que deben decidir.

Por último, quero sinalar a importancia do papel da educación (Pedroli e Van Mansvelt, 2006), comentando algúns aspectos que me parece pertinente resaltar. 


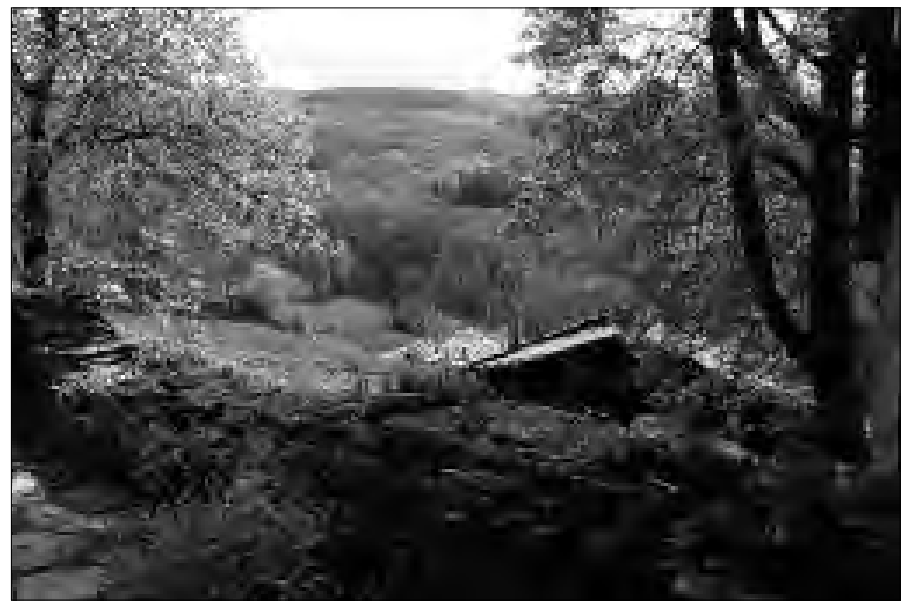

Transición entre as montañas do Courel e as Terras de Sarria, concello do Incio

Por unha parte, que a educación non é un proceso que implique tan só o sistema educativo formal, profesores e estudantes do ensino regulado, porque con frecuencia se converte o sistema educativo en depositario das esperanzas de todo cambio posible, que, neste caso, implicaría as nosas percepcións e actitudes cara á conservación e xestión responsable da paisaxe. Unha demanda que o sistema educativo non está en condicións por si só de corresponder, menos aínda desde unha disciplina curricular específica. $\mathrm{O}$ cal non impide que este asuma a súa parte de compromiso en promover cidadáns capaces de xestionar de forma responsable e sabia un patrimonio de tamaña envergadura. A aproximación desde a educación formal á importancia da paisaxe para as nosas vidas, e para o noso proxecto colectivo, pódese acometer desde moitos ámbitos educativos diferentes (Vales, 1985) e existen materiais didácticos de calidade (García e Gutiérrez, 2000). Pero o futuro da paisaxe está na aprendizaxe adulta, porque son os adultos os que teñen a responsabilidade de xestionala, e precisamos dunha pedagoxía social que lles ensine a apreciar o valioso do noso patrimonio paisaxístico e a incrementar a autoestima. Mal se pode conservar o que non se valora, e nas nosas paisaxes sobreviven elementos do pasado indispensables para construír as paisaxes do futuro, onde identidade, valor patrimonial e viabilidade ecolóxica garantan a coexistencia coas aspiracións a unha calidade de vida mellor. 


\section{BIBLIOGRAFÍA}

BONGIORNO, S. F.: «Land use and summer bird populations in southwestern Galicia, Spain», Ibis, 142 (1), 1982, p. 2-9.

BRIDGEWATER, P.: «Conexiones en los paisajes terrestres y marinos», en Beneficios más allá de las fronteras. Actas del V Congreso Mundial de Parques de la UICN, UICN, Gland, Suiza e Cambridge, Reino Unido, 2005, p. 48-55.

Burel, F. e J. Baudry:. Ecología del Paisaje. Conceptos, Métodos y Aplicaciones, Ediciones Mundi-Prensa, Madrid, 2001.

Byatt, A., A. Fothergill e A. Holms: The Blue Planet, a natural history of the oceans, BBC Worldwide Limited, London, 2001.

Carreiro, M. M., Y. Son e J. Wu (ed.): Ecology, Planning and Management of Urban Forests, Springer, New York, 2008.

Clewell, A. F. e J. ARONSOn: Ecological Restoration, Society for Ecological Restoration International, Island Press, Washington, 2007.

Fernández Vidal, E. H.: Guia de las Mariposas Diurnas de Galicia, Deputación Provincial, A Coruña, 1991.

Forman, R. T. T. e M. Godron: Landscape Ecology, Wiley, New York, 1986.

García CAmporro, C. e X. Gutiérrez Roger: A paisaxe, caderno de educación ambiental para o estudio e a interpretación da paisaxe, Xunta de Galicia, 2000.

Glover, L. K. e S. A. Earle (ed.): Defying Ocean's End, Island Press, Washington, 2004.

Hough, M.: Cities and Natural Process, Routdelge, London, 1995.

Jongman, R. e G. Pungetti (ed.):. Ecological Networks and Greenways, Cambridge University Press, 2004.

LefF, E.: Racionalidad Ambiental, Siglo XXI Editores, México D.F., 2005.

LEPART, J., P. MARTY e M. KLESCZEWSKI: «Should the effects of landscape changes on biodiversity be taken seriously?», en M. BERLAN-DARQUÉ et al. (ed.): Landscape: from knowdelege to action, Éditions Quae, Versailles, 2008, p. 29-40.

Lindenmayer, D. B. e J. F. Franklin: Conserving Forest Biodiversity, Island Press, Washington, 2002.

MAndianes CAStro, M.: «Conservación de la cultura popular gallega», en Actas Congreso Internacional da Cultura Galega, Xunta de Galicia, 1992, p. 317-319.

Martínez Carneiro, X. L. (coord.): Antela, a Memoria Asolagada, Edicións Xerais de Galicia, Vigo, 1997.

Newman, P. e I. Jennings: Cities as Sustainable Ecosystems, Island Press, Washington, 2008.

Nogué, J.: «El paisaje como constructo social», en J. Nogué (ed.): La Construcción Social del Paisaje, Editorial Biblioteca Nueva, Madrid, 2007, p. 11-24.

Otero Pedrayo, R.: «Ensaio sobre a paisaxe galega», en Paisaxe e Cultura, Editorial Galaxia, Vigo, 1955, p. 11-57.

Pedroli, B. e J. D. van Mansvelt: «Landscape and awarenesi-raising, training and education», en Council of Europe: Landscape and sustainable development: challenges of the European Lanscape Convention, Strasbourg, 2006, p. 119-142.

Roger, A.: Breve Tratado del Paisaje, Editorial Biblioteca Nueva, Madrid, 2007. 
TANSLEY, A. G.: «The use and abuse of vegetational concepts and terms», Ecology, 16, 1935, p. 284-307. TROLL, C.: «Luftbildplan and okoligische bodenforschung», en Zeitscharft der Gesellschaft fur Erdkunde Zu Berlin, 1939, p. 241-298.

VAlES, C.: «Identidade e Territorio», en X. SEOANE (coord.): A Cultura e a Creatividade Galegas de cara ao ano 2000, AACC Escola e Sociedade, I.B. Monelos, A Coruña, 1995, p. 137-150.

WHEATHER, C. P.: Urban Habitats, Routledge, London, 1999.

WiLLSON, E.: The Future of Life, Knopf, New York, 2002.

Wu, J. e R. J. HobBs: Key Topics in Landscape Ecology, Cambridge University Press, 2007. 

Relatorio

O ATLAS DAS PAISAXES

DE ESPANA

\author{
Rafael Mata Olmo
}

Universidad Autónoma de Madrid 



\section{PRESENTACIÓN: CONTEXTO E OBXECTIVOS}

O Atlas de los Paisajes de España constitúe o resultado editorial do estudo de caracterización e identificación das paisaxes de España, levado a cabo entre fins de 1998 e comezos de 2003 por un equipo de profesores e investigadores do Departamento de Geografía da Universidad Autónoma de Madrid, mediante un convenio subscrito entre o Ministerio de Medio Ambiente e a propia universidade. Segundo se indica no devandito convenio, «o seu propósito fundamental consiste en coñecer a diversidade e identidade do potencial paisaxístico do territorio español mediante bases analíticas e cartográficas que propicien iniciativas e formas de cooperación para a súa posta en valor e, asemade, a prevención das ameazas e riscos aos que a paisaxe está sometida».

Desde unha concepción holística da paisaxe como configuración e articulación das tramas naturais e humanas no territorio percibido, o estudo tiña como obxectivo expreso «identificar e caracterizar as distintas paisaxes de España e desenvolver unha taxonomía escalar, a través da agregación en unidades máis grandes que permitisen unha visión sintética da diversidade paisaxística a través da súa representación cartográfica [...] desde a perspectiva da ordenación do territorio» ${ }^{1}$. Polas dimensións do traballo e por tratarse da primeira experiencia desa natureza en España, o estudo pretende ofrecer unha lectura da paisaxe, suficientemente matizada á escala que se indicará máis adiante, mediante a identificación e cartografía das denominadas unidades de paisaxe, agrupadas en tipos e asociacións, e caracterizadas de modo tal que sexa posible comprender as súas especificidades, dinámicas e distribución espacial.

O desenvolvemento do estudo, como outros realizados en Europa -moi poucos de escala estatal no momento da publicación do Atlas, a fins de 2003-,

\footnotetext{
${ }^{1}$ Apartado 2.2. do Convenio subscrito en 1998 entre a Secretaría de Estado de Aguas y Costas do Ministerio de Medio Ambiente e a Universidad Autónoma de Madrid (Departamento de Geografía).
} 
incardínase no marco do crecente interese social e político pola paisaxe como patrimonio ambiental e cultural, como recurso e como sinal de identidade, e elemento de calidade de vida. Pero cunha diferenza importante, que a paisaxe se entende agora como unha característica de todo o territorio, de todos e cada un dos lugares, que por esa razón requiren algún tipo de acción paisaxística, de protección, nuns casos, e de xestión ou ordenación, na meirande parte deles.

A Estratexia Territorial Europea (ETE) (Comisión Europea, 1999), acordada polos ministros responsables de ordenación do territorio da UE en 1999, constitúe un paso importante no proceso de apertura do interese pola paisaxe a espazos cada vez máis extensos. Cando a ETE trata das «ameazas sobre as paisaxes culturais» e da necesidade dunha "xestión creativa» destas como obxectivo e opción política para o territorio da Unión, está a referirse de feito a moitas das paisaxes rurais e urbanas de Europa, e non só ao catálogo das máis notables ou mellor conservadas. Así e todo, a estratexia non entende aínda a paisaxe como unha cuestión que implica todo o territorio.

É o Convenio Europeo da Paisaxe (CEP) (Consello de Europa, 2000) o que asume plenamente o sentido territorial da cuestión paisaxística, é dicir, a idea innovadora, desde o punto de vista xurídico e político, de que todo territorio é paisaxe, de que cada territorio se manifesta na especificidade da súa paisaxe, independentemente da súa calidade e do aprecio que mereza. Paisaxe é, segundo o Convenio, «calquera parte do territorio, tal e como é percibida pola poboación, cuxo carácter resulta da acción de factores naturais e humanos e das súas interrelacions». Trátase dunha definición baseada en preocupacións ambientais e, asemade, culturais, cunha motivación eminentemente social e que, implicitamente, presenta a necesidade de superar as desavinzas disciplinares inherentes á polisemia da paisaxe -concretamente as derivadas da contraposición obxectivosubxectivo-, de aproveitar todas as potencialidades dunha noción aberta e integradora, e de avanzar, desde un instrumento xurídico como é o Convenio, cara á construción dun proxecto que responda ao dereito da poboación á paisaxe e ao compromiso político coa acción paisaxística.

Pois ben, o Atlas de los Paisajes de España contribúe expresamente, antes mesmo de que se proclame o Convenio no ano 2000 e segundo o proxecto coñecido daquela, ao desenvolvemento dun dos compromisos que adquirían as partes -neste caso a Administración central do Estado español- e que figuraba 
no artigo 6, apartado C: á tarefa de «identificación e cualificación», que se concreta en tres obxectivos, «identificar as súas propias paisaxes sobre o conxunto do seu territorio»; "analizar as súas características, así como as dinámicas e as presións que as modifican»; e «seguir as súas transformacións». Os dous primeiros constitúen aspectos fundamentais do Atlas.

O equipo redactor do estudo tiña xa algunha experiencia en materia de caracterización sistemática da paisaxe orientada cara á planificación territorial, aínda que a escala provincial. A mediados dos anos noventa respondera á solicitude da Consejería de Política Territorial da Comunidad de Madrid de ofrecer «unha lectura xeográfica do territorio madrileño en clave paisaxística», para o Plan Regional de Estrategia Territorial, redactado polo último goberno socialista da comunidade e nunca definitivamente aprobado.

Malia contar con esa experiencia e coa que a título individual posuían os membros do equipo en distintos e distantes territorios do Estado, desde perspectivas xeográficas e físicas, rurais e urbanas, a empresa de abordar o conxunto de España desde o punto de vista paisaxístico suscitou nos primeiros meses un labor de estudo e debate verbo das orientacións e métodos que en traballos de pequena ou mediana escala, para territorios extensos, se viñan aplicando neses anos. O panorama europeo contaba xa con algunhas iniciativas no campo da identificación e a cartografía de paisaxes, e con certas propostas metodolóxicas que, coas necesarias adaptacións, serviron de base para a elaboración do Atlas. Resultaron tamén moi interesantes algunhas de ámbito europeo e, concretamente, a que contén o Draft de European Landscapes, da Axencia Europea do Medio Ambiente (EEA, 1998); malia tratarse dun «borrador», o equipo considerou, de acordo co MMA e coa súa participación na rede Landscape Europe, da que é socio, que con el debería confluír a proposta resultante do traballo emprendido.

Os plurais sentidos da paisaxe, as súas distintas escalas e a diversidade de obxectivos dos proxectos paisaxísticos permiten comprender o carácter aberto da metodoloxía de análise da paisaxe e a variedade de instrumentos, explícita o implicitamente paisaxísticos, destinados ao seu coñecemento, á defensa dos seus valores e á xestión das súas transformacións. Esa era e, en certo modo, segue a ser a situación no noso contorno europeo cando iniciamos os traballos do Atlas. Non obstante, un repaso no último decenio da traxectoria da cuestión paisaxís- 
tica, desde o punto de vista metodolóxico, permite resaltar, ao meu ver, dous feitos importantes e estreitamente relacionados entre si: por unha banda, a formulación e lenta implantación dunha política paisaxística, con vontade de integrar os múltiples sentidos da paisaxe, vinculada sobre todo ao desenvolvemento sostible do territorio e á calidade de vida da poboación; por outra, a constitución, paulatina tamén, dunha comunidade científica e técnica, non homoxénea e lonxe aínda de se consolidar, pero comprometida coa tarefa do coñecemento, a divulgación e a intervención paisaxística, e co desenvolvemento dunha metodoloxía interdisciplinar e operativa. Nesa traxectoria afiánzase a idea da "paisaxe como carácter do territorio", tanto nas fases de estudo como nas de elaboración de propostas de actuación ${ }^{2}$.

A experiencia británica (Countryside Commission, 1998), que, coa francesa na elaboración de atlas de paisaxe de ámbitos rexional e departamental a partir da Loi Paysage de 1993, foi decisiva para o noso caso (Luginbühl, 1994; Brunet-Vinck, 2004), resulta reveladora nese sentido. Durante bastantes anos, especialmente nos setenta, no Reino Unido centrouse a atención na «avaliación da paisaxe» (landscape evaluation ${ }^{3}$ ), é dicir, na medición de aquilo que fai unha paisaxe mellor que outra. A énfase nas aproximacións teoricamente obxectivas, "científicas» e acotío cuantitativas, para a determinación do valor da paisaxe (landscape value), que chegaron a estar moi de moda ${ }^{4}$, provocou un alto grao de desilusión con este tipo de traballos e foron moitos os que consideraron inadecuado reducir algo tan complexo como a paisaxe a unha serie de valores numéricos e fórmulas estatísticas (Swanwick, 2003b). Os cambios na forma de facer da Countryside Commission advírtense xa na década seguinte, de xeito que a mediados dos oitenta se formula a ferramenta do landscape assessment cun coñecido estudo piloto en Mid Wales Upland e outros posteriores, nos que adquire unha crecente importancia a tarefa de describir e clasificar o carácter da paisaxe (landscape character), é dicir, do que fai que unha área sexa distinta ou diferente

\footnotetext{
${ }^{2}$ Unha panorámica comparativa de métodos e resultados de inventarios e caracterizacións de paisaxe a escala de Estados e grandes rexións pode verse na obra European Landscape Character Areas (Wascher, 2005), na que se inclúen referencias ao Atlas de los Paisajes de España no contexto europeo, e reflexións de interese sobre caracterizacións e tipoloxías transfronteirizas.

${ }^{3}$ No sentido de cantidade de valor de algo, neste caso a paisaxe, distinto do concepto de assessment, que se imporá anos despois (Oxford Advanced Dictionary, 2003, p. 428 e 461).

${ }^{4}$ Converteuse nunha referencia obrigada o Manchester Landscape Evaluation Study (Robinson et al., 1976).
} 
doutra -aínda que non necesariamente máis valiosa. A experiencia adquirida neses anos concretaríase nun documento metodolóxico e práctico en Escocia (Countryside Commission for Scotland, 1992) e noutro algo posterior da Countryside Commission inglesa (Countryside Commission, 1993).

No último decenio fortaleceuse a idea de landscape character como concepto central da análise e a acción paisaxística a todas as escalas, emerxendo e consolidándose como principal instrumento paisaxístico o Landscape Character Assessment (LCA), debendo entenderse este último termo, ás veces utilizado ou traducido como «avaliación», como o proceso que permite ter unha opinión fundada sobre o carácter da paisaxe tras un estudo minucioso. Da consolidación do LCA na práctica actual da Countryside Agency quixera destacar cinco aspectos principais nos que fundamentar un método aplicable a outros territorios, aínda que atento sempre ás súas peculiaridades. Trátase de aspectos que inspiraron o Atlas e que están tamén moi presentes, por exemplo, na metodoloxía dos Catàlegs de paisatge do Observatori del Paisatge de Cataluña:

- O interese polo «carácter da paisaxe»-de cada paisaxe-, é dicir, polo que fai que unha paisaxe sexa diferente doutra, e a necesidade do seu estudo en profundidade.

- O establecemento de relacións estreitas entre o carácter e a dimensión histórica da paisaxe.

- A vinculación do estudo e caracterización da paisaxe coa emisión de xuízos e a toma de decisións, aínda que con plena autonomía da primeira fase analítica do proceso.

- A énfase no potencial de uso da paisaxe a diferentes escalas.

- A necesidade de incorporar os axentes sociais implicados na construción e o uso da paisaxe.

Os métodos de estudo da paisaxe para a acción paisaxística, tanto os dedicados á ordenación e xestión dos seus valores, como os de natureza máis proxectiva ou de deseño -tradicionalmente asociados á arquitectura da paisaxecoinciden hoxe na necesidade de ler e entender o carácter de cada paisaxe. A lectura comprensiva lévase a cabo a través do coñecemento dos compoñentes e as regras que rexen a súa materialidade evolutiva-regras históricas en moitos dos casos-, e mediante a identificación e caracterización das configura- 
cións que expresan, a distintas escalas, a diferenza dunha paisaxe respecto dos seus veciños.

A tarefa de caracterización, na que debe sustentarse calquera proxecto de paisaxe, adquire, pois, un papel central, porque a intervención paisaxística ha de velar polo mantemento, a mellora e o realce do carácter de cada paisaxe, e, no caso dunha actuación creativa, concibila e desenvolvela sobre a base do coñecemento profundo dos mecanismos de produción e transformación das paisaxes afectadas (CEPAGE, 2004, p. 20).

A énfase no carácter da paisaxe como obxecto da acción paisaxística, de todo aquilo que fai a cada parte do territorio ser distinta da outra e lle outorga identidade, está hoxe na base da meirande parte dos estudos sistemáticos de caracterización da paisaxe (Mata Olmo, 2006c), e tamén o está desde logo na proposta do Atlas de los Paisajes de España. Neste aspecto, a escala condiciona grandemente a natureza do estudo paisaxístico. A escalas pequenas, para o tratamento de territorios grandes, os métodos están dirixidos, preferentemente, cara á identificación, caracterización e expresión gráfica e cartográfica da diversidade paisaxística do territorio. Pola súa escala, son estudos habitualmente realizados por equipos de especialistas, baseados sobre todo no coñecemento experto, no manexo de bases cartográficas e de datos e no traballo sistemático de campo, pero con dificultades obvias para incorporar a consulta pública e, mesmo, para facer un tratamento exhaustivo das dinámicas e da calidade da paisaxe.

A Countryside Agency recoñeceu, no tocante á proposta tipolóxica de The Character of England, que se trata de estudos «top-down» -de arriba a abaixo-, pero coa virtualidade de ofrecer unha panorámica da diversidade paisaxística para un gran territorio e de lles servir de marco a estudos de identificación de maior detalle, concretamente aos Landscape Character Assessments das demarcacións subrexionais e locais (The Countryside Agency-Scottish Natural Heritage, 2002, capítulos 2 e 6). Un procedemento similar foi o que guiou, entre outros traballos, a obra Regional Distribution of Landscape Types in Slovenia (Marusic, 1998), difundida ao iniciárense os nosos traballos, ou o documento Les territoires paysagères de Wallonie (Feltz, 2004). 


\section{AS ESCALAS DA DIVERSIDADE DAS PAISAXES. A PROPOSTA DO ATLAS DE LOS PAISAJES DE ESPAÑA}

No nivel continental europeo, referente da proposta de caracterización das paisaxes españolas, o devandito Draft da Axencia Europea do Medio Ambiente pon de manifesto que a diversidade das paisaxes obedece a factores ou a sistemas de organización de distinta capacidade explicativa segundo a escala: de carácter «zonal» ou bioclimático a escala europea, o que trasladado a España, peninsular e insular, supón distinguir xa grandes conxuntos paisaxísticos atlántico-húmidos, alpinos, mediterráneos e subtropicais -Canarias-; de carácter morfoestrutural a unha escala algo maior, na que grandes accidentes orográficos, como cadeas e sistemas montañosos de primeiro nivel, xunto a grandes chairas -altiplanos pechados, nuns casos; depresións máis ou menos abertas aos mares circundantes, noutros-, introducen outro nivel na diferenciación de ámbitos paisaxísticos de extensión considerable, nos que a importancia das formas de ocupación humana aparece aínda escasamente matizada e tende a diluírse ou ben está supeditada ás diferenzas maiores das grandes formas de relevo, unidas ás súas características fitoclimáticas 5 .

É a unha escala de maior detalle onde habitualmente comezan a fraguarse as paisaxes, é dicir, as singulares configuracións morfolóxicas do espazo, nacidas, as máis das veces, da transformación humana da natureza, impregnadas case que sempre de pasado. O peso das xeoformas de tamaño medio, dos climas locais en bastantes casos, das tramas rurais, da organización dos asentamentos e da ocupación do solo son realidades xeoecolóxicas e históricas que, a xeito de estratos, se superpuxeron e articularon no espazo, constituíndo entidades territoriais diferenciables das circundantes por certa homoxeneidade morfolóxica e visual ou, en determinadas ocasións, polo mosaico que converte a heteroxeneidade interna, a esa escala, no factor principal de singularidade e de diferenciación de organizacións paisaxísticas circundantes, isto último, particularmente, en ámbitos montañeses de escala media. Tamén a esa escala se fraguan as imaxes e os arquetipos culturais, as identidades e os símbolos paisaxísticos, e mesmo acontecen boa parte das dinámicas e os cambios paisaxísticos, e onde, na actualidade, residen as competencias políticas para o goberno e a política da paisaxe.

\footnotetext{
${ }^{5}$ Véxase, nese sentido, a controvertida proposta de Lanmap (Washer, 2005, p. 26-31).
} 
Xunto ao asunto fundamental da escala en relación coa paisaxe, outra cuestión metodolóxica importante consiste no modo de caracterizar e expresar a súa diversidade. Determinadas propostas de caracterización e identificación tenden a privilexiar os «exemplos de paisaxes representativas», sen lles prestar excesiva atención ao establecemento e xustificación de tipoloxías previas e á correspondente cartografía de todos e cada un dos tipos existentes. Son traballos que non proporcionan unha cobertura exhaustiva do espazo obxecto de estudo, e que tenden a poñer o acento, pola contra, na descrición e a ilustración gráfica das paisaxes -fotos aéreas e de superficie, esquemas de síntese e de elementos relevantes, información estatística sobre compoñentes ou actividades que se desenvolven na paisaxe descrita-, máis que na expresión cartográfica, en mapas propiamente ditos. Trátase nuns casos de "atlas temáticos», é dicir, de documentos interesados pola dimensión paisaxística e territorial dunha actividade económica ou dun modo de vida; é, por exemplo, o que ocorre cos atlas franceses sobre os bosques (Gadant, 1994), as paisaxes rurais (Brunet, 1994) ou sobre as actividades agrosilvopastorís en conxunto (Ravignan e Roux, 1990).

Dentro deste apartado pode incluírse tamén o tomo titulado Landscape and Settlements, do National Atlas of Sweden (Helmfrid, 1994). Aínda que a obra contén uns mapas sinxelos, de escala 1:1.250.000, nos que se delimita un total de cincuenta conxuntos paisaxísticos que abranguen todo o territorio nacional, o seu obxectivo non é tanto a caracterización e identificación de tipos de paisaxe cunha cobertura plena do territorio, senón máis ben a identificación de procesos de construción e diferenciación de paisaxes, e a presentación dalgúns exemplos eminentemente culturais -trazos rurais e urbanos sobre diferentes bases naturais. Estes exemplos tampouco parecen ter a pretensión de sintetizar ou representar a diversidade paisaxística sueca. Non obstante, a obra sinala explicitamente o seu obxectivo de servir de instrumento de análise e valoración para políticas de ordenación territorial e ambiental.

Fronte a este tipo de achegas, outras obras, a diferenza das anteriores, perseguen unha «identificación e caracterización paisaxística de todo o territorio», mediante a delimitación e o estudo de unidades de paisaxe, agregadas ou non en niveis taxonómicos superiores. Estas unidades caracterízanse por: 
- Cubrir todo o territorio obxecto de estudo, de maneira que cada punto ou lugar lle pertence a unha entidade paisaxística.

- Posuír límites concretos, expresados cartograficamente.

- Constituír unidades autónomas e, en ocasións, pertencer tamén a conxuntos paisaxisticamente superiores (tipos).

- Contar cunha descrición e valoración máis ou menos formalizada (tipo ficha e/ou matriz) dos compoñentes constitutivos, organización e dinámica da paisaxe.

Exemplos deste tipo de estudos son os xa mencionados The character of England: landscape, wildlife \& natural features, da Countryside Commission e da English Nature (Countryside Commission, 1998), e a obra Regional Distribution of Landscape Types in Slovenia (Marusic, 1998), encargada e editada pola Oficina Nacional de Planificación Física do Ministerio de Medio Ambiente e Planificación Física da República de Eslovenia. O documento inglés sobre a paisaxe ten a significativa denominación de Character of England, o que é expresivo xa da súa concepción e dos seus obxectivos. Tamén o é o feito de que na súa elaboración participaran dous organismos con sensibilidades e prioridades distintas, pero confluentes no interese pola paisaxe, polo "carácter de Inglaterra»: a Countryside Commission e English Nature. As unidades de referencia denomínanse, de xeito ben expresivo tamén, Character areas, cunha determinada correspondencia coas Natural areas. Resultan un total de 181 unidades de paisaxe ou character areas, o que, tendo en conta a superficie total do espazo abarcado, é proba da finura e exhaustividade coa que se procedeu á hora de definir, caracterizar e, xa que logo, delimitar o territorio inglés ${ }^{6}$.

O estudo da paisaxe de Eslovenia, tal e como queda claramente exposto nas súas Methodological Bases, ten puntos en común co documento de Inglaterra -identificación e cartografía exhaustiva de unidades/tipos de paisaje-, pero engade unha maior complexidade metodolóxica e empírica. $\mathrm{O}$ Atlas de Eslovenia traballa a tres escalas ou niveis, de xeito que cada lugar ou punto do territorio forma parte dunha «subunidade», dunha «unidade» e dun dos grandes con-

${ }^{6} \mathrm{O}$ método desenvolvido para cartografar e describir o "carácter da paisaxe» resulta da combinación da análise estatística de variables previamente definidas -técnica TWINSPAN- e o traballo de identificación e validación a cargo dun equipo de especialistas (Countryside Commission, 1993 e 1998). 
xuntos rexionais de paisaxe, definidos por criterios eminentemente xeomorfolóxicos ${ }^{7}$. Dentro de tales conxuntos rexionais pódense distinguir unidades escalarmente inferiores, coa incorporación de criterios diversos: xeomorfolóxicos, climáticos locais ou subrexionais nunha segunda instancia, e, finalmente, usos do solo, asentamentos e construcións culturais no nivel de unidade ${ }^{8}$.

Pois ben, o ensaio de caracterización das paisaxes de España optou finalmente -non sen antes intentar un método de «casos» como o de Suecia- polos modelos de Inglaterra e Eslovenia e polas experiencias igualmente coñecidas dalgúns atlas rexionais franceses. $\mathrm{O}$ estudo aborda, pois, a identificación e caracterización das paisaxes de España, é dicir, de todo o seu territorio, tanto peninsular como insular; iso supón que cada punto do espazo xeográfico foi identificado e caracterizado paisaxisticamente ou, con outras palabras, asignado a unha «unidade de paisaxe» e ao seu correspondente "tipo», resultante da agrupación de unidades de paisaxe afíns por semellanzas formais e funcionais. O estudo proporciona, así, unha cobertura completa de todo o territorio.

En todo caso, cómpre ter presente que a obra é o resultado dun traballo realizado nun tempo previamente acordado, insuficiente quizais para un territorio e para o desenvolvemento dun método como o adoptado, que non tiña precedentes de parecida natureza en España. Por máis que a literatura experta, tanto sectorial como rexional -sobre comarcas, subrexións e, en menor medida, rexións no sentido autonómico-, é certamente abundante en materia de paisaxe, sobre todo a xerada pola Xeografía, os enfoques, os métodos e as datas de edición das obras dispoñibles resultan moi dispares. A execución do estudo partiu, sempre que foi posible e se estimou oportuno, da abundante bibliografía existente; así e todo, o obxectivo de cobertura completa do territorio e de aplicación dun método homoxéneo, por riba de límites administrativos ou de monografías de investigación, supuxo un esforzo extraordinario.

\footnotetext{
${ }^{7}$ Estes conxuntos son as paisaxes da rexión litoral, as paisaxes da rexión alpina, as paisaxes da rexión subalpina, as paisaxes cársticas do interior de Eslovenia e as paisaxes da rexión subpanónica.

${ }^{8}$ Para cada un dos niveis escalares preséntase un modelo de ficha diferente, que recolle e organiza a información paisaxística de maneira matizadamente distinta. Ao noso ver, este asunto non está resolto con claridade suficiente, de xeito que non queda convenientemente xustificada a distinta organización dos que poderiamos chamar niveis escalares de ficha, nin como se discrimina a información que se incorpora a un e outro tipo de ficha.
} 


\section{PUNTOS DE CONVERXENCIA ARREDOR DUN CONCEPTO DE PAISAXE ÚTIL PARA UNHA CARACTERIZACIÓN E TIPOLOXÍA DAS PAISAXES DE ESPAÑA}

Un repaso atento das diferentes aproximacións temáticas e/ou disciplinares ao concepto e aos métodos de estudo da paisaxe sitúanos, como escribiu hai anos o xeógrafo Paul Claval, «diante dun dominio aínda imperfectamente estruturado» (Claval, 1987, p. 354). Non obstante, malia ese panorama aínda vixente de pluralidade e de diversidade, a lectura de diversos estados da cuestión recentemente realizados desde distintas disciplinas ${ }^{9}$ e os traballos de identificación e delimitación paisaxística xa comentados poñen de manifesto a existencia de determinadas "liñas de forza», de puntos de encontro entre enfoques, que tenden a converxer, tanto no terreo do coñecemento e a interpretación do feito paisaxístico, como na vontade de incorporar o estudo da paisaxe ás tarefas de defensa do patrimonio e de planificación territorial.

Das converxencias que se advirten, destácanse aquí algunhas delas (Mata Olmo, 1997 e 2006a), concretamente as que sustentan a idea que os autores da caracterización e identificación das paisaxes de España teñen da paisaxe e que, xa que logo, inspiraron a tarefa realizada.

A primeira liña de forza no tocante á paisaxe é a supremacía do espazo, un espazo concreto que adquire identidade e singularidade pola peculiar organización dos feitos físicos e humanos que configuran un territorio. A paisaxe é, pois, a forma que adoptan os feitos xeográficos, da natureza e da sociedade, sobre a superficie da terra. Asemade, polo que supón de exercicio individual e colectivo de «visualización», de experiencia multisensorial do territorio -en palabras de Fernando González Bernáldez-, a paisaxe contén as representacións que temos dos escenarios sociais e naturais, os significados que lles outorgamos e os valores que lles concedemos, de modo persoal ou colectivo. A paisaxe sitúase así no plano de contacto entre os feitos naturais e os de ocupación humana; tamén no dos obxectos e os suxeitos que os perciben e actúan sobre eles (Martínez de Pisón, 1983 e 1993).

Entre unha posición subxectivista e estética, que pon o acento no papel constituínte da mirada, e outra realista, que destaca a existencia de algo alén da repre-

9 Véxanse, entre outros, Ihse (1996), Luginbühl (1996), Olwig (1996), Skanes (1997), Mathewson (1998), Zoido e Posocco (1998) e Mata Olmo (2006a). 
sentación, cabe -como di o filósofo Jean-Marc Besse- un concepto que sintetiza a tensión entre, "por unha banda, a actividade do espectador e, pola outra, o feito de que hai algo que ver, algo que se lle ofrece á vista» (Besse, 2000, p. 100). A definición proposta polo Convenio, en sintonía coa experiencia dalgúns estudos de caracterización e ordenación paisaxística do último decenio, recoñece que a paisaxe corresponde á orde do visible, pero se refire, asemade, á materialidade de "cada parte do territorio», ao seu "carácter», que é o resultado das interrelacións entre factores naturais e humanos.

Un segundo punto de converxencia que se advirte nos estudos recentes sobre a paisaxe é a aproximación holística (Antrop, 1999). Non basta para iso coa acumulación e o catálogo dos múltiples atributos da paisaxe e dos mecanismos de funcionamento, por máis que sexa necesario. Han de investigarse tamén os nexos de recorrencia que os articulan nun todo organizado. Por iso mesmo, o coñecemento da organización paisaxística, desde esta perspectiva holística, é tan importante como a análise de cada un dos seus compoñentes.

A importancia da organización paisaxística conduce a examinar outro elemento de encontro ou converxencia dos recentes estudos da paisaxe: o papel central da forma, da morfoloxía do espazo. A forma, entendida non só como elemento característico ou caracterizador dunha paisaxe, senón como «estrutura morfolóxica», como configuración do conxunto. Neste mesmo sentido, Phipps e Berdoulay (1985) afirman que a rehabilitación do interese pola forma constitúe unha condición previa para a consideración dunha auténtica ciencia da paisaxe, fronte a certo cientifismo que «non só quere impoñer a primacía dos procesos sobre a forma, senón que reivindica, de feito, para os primeiros o monopolio da cientificidade».

Rehabilitar o significado e o estudo das formas non supón subestimar os procesos. Non hai interpretación da paisaxe na súa xénese, no seu actual estado e no seu devir sen o coñecemento dos procesos ecolóxicos e sociais que producen e reproducen a paisaxe. A idea de proceso supón movemento, transformación, implica o tempo na súa propia definición. Se o espazo está na esencia da paisaxe, pola mesma razón ten que estalo o tempo. Non hai paisaxe sen espazo e sen historia. E non se trata dun tempo único, dunha historia única, senón dos tempos e as historias dos distintos compoñentes que configuran a paisaxe: o tempo dos procesos naturais, o tempo das transformacións técnicas e materiais, o 
tempo das relacións sociais, o tempo das percepcións e das valoracións culturais da paisaxe; a historia da paisaxe non pode ser máis que a complexa e dialéctica articulación das historias dos seus distintos compoñentes e sistemas. Milton Santos escribiu con razón que «nada na paisaxe cambia ao mesmo tempo, á mesma velocidade e no mesmo sentido" (Santos, 1978). Iso, que resulta fundamental para comprender a dinámica da paisaxe, aínda o é máis para o seu entendemento prospectivo e a súa ordenación. Ordenar a paisaxe esixe saber que calquera modificación dos seus compoñentes ecolóxicos e sociais -entre estes últimos, a propia percepción individual e colectiva que desta se ten- provoca cambios de distinto signo e intensidade no conxunto do sistema paisaxístico e a procura dun novo equilibrio.

Como xa dixemos nunha obra anterior sobre as paisaxes da comunidade madrileña, á análise da paisaxe reprochóuselle, ás veces, a disparidade entre o peso visual e o peso funcional (Gómez Mendoza, 1999, p. 15). É certo que nos estudos paisaxísticos domina unha tendencia, por outra parte comprensible, ao protagonismo e á inercia das formas sobre a dinámica das funcións subxacentes á paisaxe; iso provoca que, con frecuencia, as realidades da paisaxe estean desfasadas en relación coas realidades funcionais. A tarefa de identificación e caracterización das paisaxes de España tivo precisamente como un dos seus obxectivos principais -outra cousa é que o conseguira sempre- trabar, conceptual e metodoloxicamente, forma e función na comprensión das unidades de paisaxe, na argumentación dos tipos de paisaxe e nunha primeira aproximación ao diagnóstico dos seus valores.

\section{A IDENTIFICACIÓN DAS PAISAXES E A SÚA EXPRESIÓN CARTOGRÁFICA. A PROPOSTA DO ATLAS}

O obxecto principal do Atlas, como vimos reiterando ata aquí, é a identificación e caracterización das paisaxes de España. Posto que a paisaxe é unha característica de todo o territorio ou, con outras palabras, a face dunha capa continua e complexa que envolve a superficie da Terra, a tarefa fundamental consistiu en buscar as descontinuidades paisaxísticas e identificar, a partir de aí, as configuracións do territorio que se expresan en paisaxes con entidade propia e que se 
distinguen, xa que logo, das circundantes. Estas descontinuidades son de diversa natureza e extensión, pero, en xeral, son percibidas con claridade na forma do territorio e están identificadas nos mapas topográficos e temáticos.

A identificación das paisaxes realizouse e expresouse cartograficamente, mediante recintos que, á escala considerada, envolven áreas homoxéneas desde o punto de vista paisaxístico. A homoxeneidade adoita resultar relativa, xa que unha característica da paisaxe é, xustamente, a súa diversidade interna, que se aprecia e matiza a medida que se amplía a escala. A escala de traballo utilizada na tarefa de identificación e delimitación sistemática das paisaxes peninsulares foi 1:200.000; trátase dunha escala media, que se considerou axeitada para abordar o conxunto do territorio do Estado español, tendo en conta os obxectivos e as posibilidades desta obra. Non obstante, na caracterización das paisaxes das que se realizou un estudo específico e monográfico -contido do capítulo VII-, a escala de traballo foi 1:50.000 e, en determinados casos, mesmo 1:25.000. As illas recibiron un tratamento a maior escala, tanto por seren territorios relativamente reducidos, como pola diversidade de paisaxes que a meirande parte delas alberga. De non terse procedido así, cada illa constituiría unha paisaxe, feito que está moi lonxe do rico patrimonio paisaxístico dos espazos insulares españois.

A escala dos mapas que inclúe o Atlas é diversa e depende das expresións cartográficas dos distintos niveis taxonómicos establecidos. Non obstante, as cincuenta e nove láminas que de maneira sistemática e consecutiva conteñen todas as paisaxes de España, tanto peninsulares como insulares, ademais dos territorios do Norte de África, son de escala aproximada 1:700.000.

O método de traballo desenvolvido nesta caracterización das paisaxes españolas permitiu chegar a unha taxonomía xerarquizada composta por tres niveis. A diversidade das paisaxes de España exprésase, no seu nivel básico, nas denominadas «unidades de paisaxe» ou, simplemente, "paisaxes». Identificouse e cartografouse un total de 1262. Cada unidade está definida, á escala de traballo adoptada, pola súa homoxeneidade interna e a súas diferenzas con respecto das paisaxes contiguas. A singularidade é, xa que logo, a súa principal característica e resulta das relacións particulares que se establecen entre as comunidades locais e o seu territorio.

O segundo nivel da taxonomía é o chamado «tipo de paisaxe», dos que se identificaron, cartografaron e describiron cento dezaseis. Cada tipo resulta da 
agrupación de unidades cuxas estruturas se repiten no territorio. Á escala de traballo do Atlas e tendo en conta os seus obxectivos, os tipos achegan unha lectura sintética, pero suficientemente matizada, das grandes configuracións paisaxísticas de España. $\mathrm{Na}$ tarefa de identificación e caracterización dos tipos, o feito autonómico, entendido como proceso de construción paisaxística a partir de distintas historias territoriais, resultou na meirande parte dos casos decisivo. Xustamente por esa razón, os tipos de paisaxe están restrinxidos, con moi poucas excepcións, a dominios autonómicos, non porque, a priori, se buscara unha tipoloxía de base autonómica, senón porque boa parte dos cadros paisaxísticos a esta escala responden a procesos de longa duración, que aconteceron no marco de territorios históricos de ámbito autonómico na actualidade.

No nivel máis elevado da taxonomía definíronse as «asociacións de tipos», agrupacións que integran tipos próximos pola súa configuración topográfica, polas súas características bioclimáticas e por semellanzas nos grandes trazos de organización dos usos do solo. Este nivel supera, na meirande parte dos casos, o ámbito autonómico e dálles unha maior importancia aos feitos fisiográficos do territorio, proporcionando un mapa relativamente abstracto en relación coa realidade da paisaxe, pero útil como expresión cartográfica xeral e sintética.

\section{AS PAISAXES}

\section{As unidades de paisaxe}

$\mathrm{Na}$ base da identificación e caracterización paisaxística que o Atlas proporciona están as «paisaxes» ou as tamén chamadas «unidades de paisaxe». Trátase dunha noción de uso frecuente e crecente, cuxa definición e contidos non están, así e todo, definitivamente pechados (Pérez-Chacón, 2002). Caben, entre outros, entendementos de signo ecolóxico, morfolóxico ou visual, que poñen o acento, respectivamente, nas relacións funcionais do mosaico de manchas do territorio (Forman, 1995; e Terradas, 2003, p. 66-67), na fisionomía e na orde da configuración territorial ou na articulación espacial das panorámicas e as concas visuais (Tévar, 1996). Na actualidade, como pon de manifesto un recente traballo que valora a catalogación paisaxística en Francia nos últimos dez anos 
(Brunet-Vinck, 2004), empréganse, ademais, outras denominacións para referirse ás distintas entidades paisaxísticas, segundo sexa a escala.

A definición integradora de paisaxe da Convención de Florencia e numerosas experiencias de análise e ordenación paisaxísticas con enfoque territorial conducen cara a un concepto de unidade de paisaxe que, ademais de claro e operativo no marco de cada proxecto, debería expresar sobre todo o carácter e a identidade de cada paisaxe a unha determinada escala. Unha unidade de paisaxe debería ser, pois, aquela combinación de elementos que xera una fisionomía particular, unha organización morfolóxica diferenciada e diferenciable que fai unha parte do territorio distinta de outra. Este entendemento de unidade de paisaxe implica que a dimensión paisaxística do territorio reside na súa particular fisionomía, nunha determinada disposición e articulación das partes que compoñen a face do territorio e lle outorgan o seu peculiar carácter.

A énfase nos aspectos morfolóxicos -no tocante á configuración- á hora de identificar e caracterizar unidades de paisaxe non é allea -máis aínda cando a paisaxe se aborda con intención de actuar- ao funcionamento e ás relacións dos elementos que modelan a forma e á organización visual das fisionomías. O funcional -ou, se se quere, o sistémico- e o perceptivo constitúen aspectos fundamentais na explicación e na prognose da diversidade paisaxística expresada en unidades de paisaxe. Así debe entenderse o Convenio Europeo, cando afirma que o "carácter» da paisaxe «resulta da acción de factores naturais e/ou humanos e das súas interrelacións».

A nosa proposta de análise da diversidade paisaxística en unidades da paisa$\mathrm{xe}$, partindo da experiencia en proxectos territoriais, consiste, pois, en partir da forma como base do carácter, interpretar dinámica e funcionalmente cada configuración, atendendo ás relacións dos seus principais elementos constitutivos -naturais, de usos do solo e histórico-patrimoniais- e considerar os aspectos visuais en relación con cada unidade de paisaxe -capacidade de emisión e recepción de vistas, puntos e percorridos de observación, intervisibilidade con outras unidades e co conxunto do territorio, fraxilidade-, e non ao contrario. É dicir, óptase por unha identificación da diversidade da paisaxe baseada no seu carácter e non en concas visuais, por máis que as cuestións de visibilidade deban ser tratadas no marco de cada unidade paisaxística.

Como xa se dixo, no Atlas identificáronse e cartografáronse un total de 1262. Cada paisaxe é, pois, unha configuración territorial diferenciada, única e singu- 
lar, que foi adquirindo os caracteres que a definen a través, como norma xeral, dunha longa historia de intervención humana na natureza. Natureza e cultura están, pois, presentes en todas as paisaxes, con diverso peso explicativo en cada caso e con diferentes expresións morfolóxicas.

Nun territorio montuoso e fragmentado, como o de boa parte da Península Ibérica e o dos arquipélagos balear e canario, as formas do relevo contribúen decisivamente a diferenciar e caracterizar moitas paisaxes, especialmente, como é lóxico, as montañosas. Ademais, como xa se dixo, a encrucillada climática na que se atopa España, coa existencia de tres grandes dominios -atlántico, mediterráneo e subtropical-, matizados, asemade, polas características e a disposición do relevo, ten notables repercusións sobre a capa viva da superficie terrestre, sobre as formas e sistemas de aproveitamento humano dos recursos naturais e, en definitiva, sobre a paisaxe.

Asemade, a fonda pegada histórica de moitas paisaxes non é máis que a expresión morfolóxica dun longo proceso de construción social do territorio, no que se suceden e superpoñen modelos distintos de organización do espazo; nuns casos, modelos de longa duración, de estabilidade secular, que xa cristalizaron, en xeral, en estruturas paisaxísticas de considerable complexidade e riqueza, tanto ecolóxica como formal e estética; noutros, como acontece recentemente en numerosas paisaxes, son ciclos curtos, moi dinámicos e cunha gran capacidade de recrear ou de xerar paisaxes radicalmente novas.

Non existe, así e todo, un só elemento ou unha única interacción que se comporte como argumento paisaxístico exclusivo. Todos os factores mencionados están relacionados e todos son, xa que logo, causas eficientes do resultado final, da paisaxe, das paisaxes. Os 1262 que se identificaron, diferenciaron e cartografaron nesta obra responden, xustamente, a particulares formas de articulación de estruturas e procesos físicos, de historia cristalizada no territorio e de dinámicas recentes, que se expresan fundamentalmente a través do estado e dos cambios dos usos do solo, e, en determinados casos, de procesos naturais moi activos.

As paisaxes identifícanse nos mapas do Atlas mediante unha numeración correlativa por tipos - dos que se tratará a continuación- e unidades; así mesmo, reciben un nome, que pretende ser sinxelo e adecuado ás súas características e localización, e expresivo da súa imaxe percibida. Dados os obxectivos e o alcance desta obra, non foi posible o tratamento específico de cada unha das 1262 paisaxes iden- 
tificadas e cartografadas. A caracterización destas abordouse, non obstante, para unha selección de noventa e catro paisaxes peninsulares - unha por cada tipo- e once paisaxes insulares, que representan a diversidade paisaxística dos arquipélagos. Tentouse que esta rede de exemplos se estendese por todas as provincias e illas e que os casos tratados contivesen, sempre que fose posible, os trazos morfolóxicos, funcionais, dinámicos e perceptivos do tipo paisaxístico ao que pertencen.

O estudo dos casos seleccionados fíxose por medio de fichas normalizadas, con catro apartados que se refiren a outros tantos aspectos básicos dunha caracterización territorial e dinámica da paisaxe. $\mathrm{O}$ primeiro e fundamental aborda o que se deu en chamar a «Organización da paisaxe», é dicir, a articulación dos elementos e os procesos de maior capacidade explicativa da forma e o carácter da paisaxe. Á escala de traballo adoptada, as formas, a diversidade e o encaixe das coberturas vexetais e dos usos do solo ás bases físicas da paisaxe e ao seu diverso potencial ecolóxico, e as tramas construídas, desde os asentamentos e as infraestruturas, ao parcelario e o viario, constituíron na meirande parte dos casos os compoñentes principais da estrutura da paisaxe e da súa singularidade con respecto aos circundantes.

A «Dinámica da paisaxe» constitúe o segundo apartado das fichas de caracterización dos casos seleccionados. A dinámica paisaxística remite, sobre todo, ás tendencias e aos cambios conseguintes ou á estabilidade que se advirten nos compoñentes e funcións do territorio de maiores implicacións na paisaxe. É, por así dicilo, unha historia de curta duración dos usos do solo e dos sistemas de xestión, tanto agropecuarios e forestais como urbanos, e das funcións, novas ou tradicionais, que gravitan sobre o territorio e contribúen a modelar e remodelar a paisaxe. Este capítulo pretende ver cara a onde vai a paisaxe e cales son as claves da súa máis recente evolución.

A caracterización formal, funcional e dinámica das paisaxes complétase nas fichas con dúas epígrafes, unha dedicada a aspectos visuais e perceptivos, e outra, á valoración. $\mathrm{O}$ apartado que se dedica á «Percepción da paisaxe» ocúpase tanto de aspectos relacionados coa composición e a forma da paisaxe, como, sobre todo, das características visuais da escena, a súa organización en planos e as posibilidades de visión e contemplación da paisaxe, tanto desde atalaias, institucionalizadas ou non, como desde vías de comunicación. Por último, o cuarto apartado contén unha "Valoración cualitativa», de contido loxicamente variable, segundo o carác- 
ter de cada paisaxe, pero articulada sempre arredor do que nesta obra se consideran eixes fundamentais de calidade paisaxística: valores ecolóxicos, valores perceptivos e valores histórico-culturais, estes últimos estreitamente ligados ao sentido de identidade que, en maior ou menor medida, toda paisaxe posúe.

Fíxose, finalmente, para cada unha das paisaxes analizadas, un texto que contén unha imaxe cultural. As imaxes culturais están cualificadas polo seu valor estético, descritivo ou explicativo, nacen da xenialidade, a sensibilidade ou a arte dos seus autores ou son o reflexo da imaxe social, «esa imaxe que nace de moitas individuais e subxectivas, que se forxa a través da intercomunicación, imaxes do consenso implícito, consuetudinarias, que morren coa sociedade ou se transmiten, de maneira máis ou menos consciente, se perpetúan e se van enriquecendo ou degradando a través dos transmisores» (Sanz, 2002). Nalgúns casos, foron incorporadas descricións de científicos ou coñecedores do territorio, clásicas xa na meirande parte das veces, pero tamén novas, que contribuíron de xeito significativo a configurar e a difundir a imaxe e o carácter da paisaxe considerada. Noutros casos, son relatos de viaxeiros ou textos literarios que conteñen particulares e estéticas visións da paisaxe, que realzan as súas características ou valores, e contribúen tamén, a través da expresión literaria, a crear arquetipos e a construír referentes paisaxísticos, indisociables da súa propia imaxe literaria. Imaxes, en fin, que xorden sempre da contemplación e o coñecemento das paisaxes, pero tamén de vivencias, experiencias estéticas e de referencias que, a través da palabra escrita, lle engaden valores intanxibles á paisaxe.

\section{CADRO 1}

Síntese da caracterización paisaxística da Campiña cordobesa (Tipo de paisaxe 54, Campiñas andaluzas, Unidade de paisaxe 10)

\subsection{CAMPIÑA CORDOBESA}

1. LA ORGANIZACIÓN DEL PAISAJE

- UN PAISAJE SUAVEMENTE ALOMADO

- GRANDES LABRADÍOS CEREALISTAS CAMPIÑESES

- POCOS PUEBLOS Y MUCHOS CORTIJOS

2. DINÁMICA DEL PAISAJE

- LA ESTABILIDAD FORMAL QUE IMPONE LA ESTRUCTURA ACORTIJADA 
- EL REFLEJO EN LOS CULTIVOS DE LA REFORMA DE LA PAC

- LA INEXISTENCIA DE PARCELACIONES Y DE HÁBITAT RESIDENCIAL DISEMINADO

\section{PERCEPCIÓN DEL PAISAJE}

- EL ENCADENAMIENTO DE PRIMEROS PLANOS ACOLINADOS

- LOS MIRADORES PANORÁMICOS PERIFÉRICOS

- LAS VISIONES LINEALES: LA RUTA DEL GUADAJOZ

4. LOS VALORES ECOLÓGICOS CULTURALES Y PERCEPTIVOS

- LA PUREZA DE UN PAISAJE LATIFUNDISTA HISTÓRICO

- LOS CORTIJOS

- UN HÁBITAT PARA LAS AVES ESTEPARIAS

5. IMAGEN CULTURAL DEL PAISAJE

"Abajo el paisaje era de lo más amable, pues la Campiña se extendía en una suave sucesión de lomas y vallonadas, en su totalidad cubierta por trigales, viñedos y huertos de frutales". A. S. Mackenzie, A year in Spain by a young american, 1829.

6. MAPA DE LOCALIZACIÓN

7. FOTOGRAFÍAS

A maiores escalas, para ámbitos xeográficos máis reducidos e en xeral en estudos explicitamente orientados cara á ordenación territorial, a diversidade da paisaxe maniféstase nun mosaico de unidades ou áreas paisaxísticas sensiblemente maior, porque emerxen daquela elementos e patróns da paisaxe diluídos en aproximacións máis xerais e sintéticas. Por exemplo, a Horta de Murcia, que no Atlas é unha paisaxe, descomponse en máis dunha decena de unidades paisaxísticas a escala 1:25.000, no Estudio y directrices de paisaje para el área metropolitana de Murcia (Región de Murcia, 2002), elaborado para o Goberno rexional (Mata e Fernández, 2004). Diferenzas internas na forma e tamaño do parcelario rural, na disposición dos camiños rurais e redes de rego, ou na densidade e morfoloxía do sistema de asentamentos, xunto ao significado paisaxístico local de determinados elementos naturais - meandros do río Segura, conos de dexección e abanos aluviais, fronte á chaira de inundación, etc.- xustifican a diversidade de configuracións paisaxísticas dentro dunha paisaxe como a Horta murciana, que a unha determinada escala resulta rotunda e indiscutible.

Algo parecido aconteceu co estudo de paisaxe levado a cabo dentro dos traballos previos do Plan Territorial Insular (PTI) de Menorca, aprobado en 2003 (Consell Insular de Menorca, 2003). As sete unidades de paisaxe identificadas 
polo Atlas na illa, agrupadas en dous tipos paisaxísticos -Chans de Menorca e Pequenas serras, montes e turons das Baleares-, convertéronse no PTI nun conxunto de vinte e tres paisaxes traballando a escala 1:25.000 (Mata Olmo, 2006b). Os barrancos, que á escala do Atlas non eran máis que elementos constitutivos dos chans litorais do sur da illa, adquiren a maior escala entidade paisaxística suficiente, como lles ocorre tamén aos densos tecidos de urbanización turística dalgunhas áreas do litoral ou ás dúas cidades menorquinas -Ciutadella e Maó- e súas áreas periurbanas. A estas escalas grandes e con obxectivos explícitos de intervención, as iniciativas de consulta pública resultan pertinentes e moi útiles, tanto para caracterizar as paisaxes, como para valorar a percepción social dos seus cambios e as aspiracións paisaxísticas da poboación.

\section{Os tipos de paisaxe}

O método de identificación das paisaxes de España nesta obra baseouse, segundo o que se dixo ata aquí, na procura da unidade e homoxeneidade interna de cada paisaxe e, xa que logo, no contraste da súa configuración coas adxacentes, é dicir, con outras paisaxes. Cada unidade de paisaxe é, pois, única e singular a calquera escala. Non obstante, hai paisaxes que polos seus trazos formais e funcionais e pola súa propia situación xeográfica resultan próximas nas súas características e na súa territorialidade. Esta proximidade de paisaxes que comparten trazos semellantes e un ámbito territorial común, e en moitas ocasións continuo, constituíu a base para o establecemento dos tipos de paisaxe, o segundo nivel da taxonomía paisaxística formulada. Á súa descrición e interpretación está dedicado o capítulo $\mathrm{V}$.

Están identificados e descritos cento dezaseis tipos de paisaxe, de diferentes dimensións territoriais, cada un cunha cor propia na cartografía sistemática que conteñen as cincuenta e nove follas do Atlas. A denominación dos tipos expresa ben os grandes elementos e trazos que interveñen na súa identificación. En todos os casos, agás nos tipos paisaxísticos de base urbana - «randes cidades e áreas metropolitanas», "Capitais canarias e o seu periurbano» e «Cidades norteafricanas»-, hai unha primeira referencia á fisiografía, que tan decisivo papel desempeña a esta escala na configuración e percepción da paisaxe. Noméanse así macizos montañosos, serras, serras e vales, terras altas, páramos, montes, cerros 
e outeiros, congostras e ladeiras, depresións, engrobas, penechairas, campiñas, vales e veigas, entre outros.

Pero xunto a ese criterio básico de diferenciación paisaxística, a denominación e o contido dos tipos incorpora inmediatamente trazos xeográficos e autonómicos, que remiten tanto a aspectos bioclimáticos e morfolóxicos de menor escala, como, trabados frecuentemente cos anteriores, a aspectos especificamente autonómicos, entendidos como expresións paisaxísticas de vellas historias territoriais, sobre todo, de particulares formas de organización dos usos do solo e dos asentamentos. Dese xeito, morfoestruturas matizadas por particulares condicións bioclimáticas e accións humanas seculares de construción da paisaxe, ou máis recentes segundo os casos, cristalizan nos tipos de paisaxe. Neles -cómpre recalcalo- a dimensión rexional adquire un peso fundamental, tanto morfolóxico e cultural, como, xa que logo, perceptivo e de identidade. Fálase así, por exemplo, de «Macizos montañosos béticos» ou de «Serras do Sistema Central»; de "Congostras e chans do Miño e do Ulla», de "Congostras da Depresión Central Catalá» ou de «Concas murcianas»; de "Campiñas da Meseta Norte» ou de «Campiñas andaluzas»; de «Veigas do Segura» ou de «Vales industriais vascos»; de «Mesas aragonesas» ou de «Rasas cantábricas»; da "Ribeira do Ebro» ou das «Foces e gargantas ibérico-levantinas»; de "Cumes canarios» ou de "Chans de Menorca». Hai tipos que engloban moitas paisaxes, con algunhas diferenzas significativas na súa configuración, pero sen entidade suficiente como para dar lugar a tipos específicos. Neses casos, distinguíronse subtipos de paisaxe, que pola claridade da cartografía non se considerou pertinente trasladar aos mapas, pero cuxas características básicas se sintetizan na descrición dos tipos aos que pertencen.

Así pois, á escala de traballo do Atlas e tendo en conta os seus obxectivos, os tipos contribúen a facer unha lectura sintética, pero suficientemente matizada, das grandes configuracións paisaxísticas de España. Na tarefa de identificación e caracterización dos tipos, o feito autonómico, entendido como proceso de construción paisaxística a partir de distintas historias territoriais, resultou na meirande parte dos casos decisivo. Xustamente por esa razón, os tipos de paisaxe están restrinxidos, con poucas excepcións, a dominios autonómicos, non porque, a priori, se buscara unha tipoloxía de base autonómica, senón porque boa parte dos cadros paisaxísticos a esta escala responden a procesos de longa duración, que aconteceron no marco de territorios históricos de ámbito autonómico na actualidade. 


\section{As asociacións de tipos de paisaxe}

Na taxonomía proposta, por riba dos tipos están as denominadas «Asociacións de tipos». Constitúen o nivel maior de abstracción da caracterización paisaxística de España e resultan de agrupacións de tipos en función de semellanzas esencialmente fisiográficas, matizadas, no caso das paisaxes de montaña, polo factor bioclimático. Certamente, canto maior é o nivel de abstracción, o afastamento da realidade paisaxística resulta tamén máis grande. Non obstante, a visión sintética que proporcionan as asociacións de tipos posibilita facer observacións e interpretacións que non resultan factibles nos niveis inferiores da taxonomía, facilita tamén unha visión global do territorio e, sobre todo, permite realizar unha expresión cartográfica sintética e lexible dos grandes trazos territoriais da diversidade paisaxística de España.

Distinguíronse, en total, trinta e catro asociacións, tanto peninsulares como insulares, aínda que no tocante aos arquipélagos, polas súas dimensións e por aspectos específicos da súa configuración e diversidade paisaxísticas, se farán posteriormente algunhas matizacións. Nas paisaxes de montaña, en sentido amplo, os grandes conxuntos orográficos deron lugar a oito asociacións, resultantes da distinta entidade altitudinal e morfolóxica destes conxuntos, matizada por aspectos relacionados coa súa posición peninsular e as súas fundamentais implicacións climáticas e biolóxicas: nos macizos, por exemplo, distinguiuse entre as paisaxes dos denominados macizos setentrionais -máis húmidas-, os macizos do interior ibérico e os macizos das cordilleiras béticas; nas serras, pola súa parte, as mediterráneas das continentais, as pirenaicas dos montes e vales atlánticos e subatlánticos e mais do conxunto de serras, cerros e vales andaluces, levantinos e estremeños.

Nas restantes asociacións pesaron máis as grandes formas naturais de configuración da paisaxe -indisociables bastantes delas de distintos modos de aproveitamento dos recursos e da organización social do espazo-, que outros caracteres derivados da súa posición xeográfica.

As agrupacións de paisaxes, "tipos e asociacións», reúnen diversas paisaxes pero procurouse que a abstracción non se afastase totalmente da realidade, base de calquera paisaxe. Cada nivel da escala taxonómica: paisaxe, tipo e asociación ten unha ou varias expresións cartográficas no Atlas. Distínguense, así, vales, 


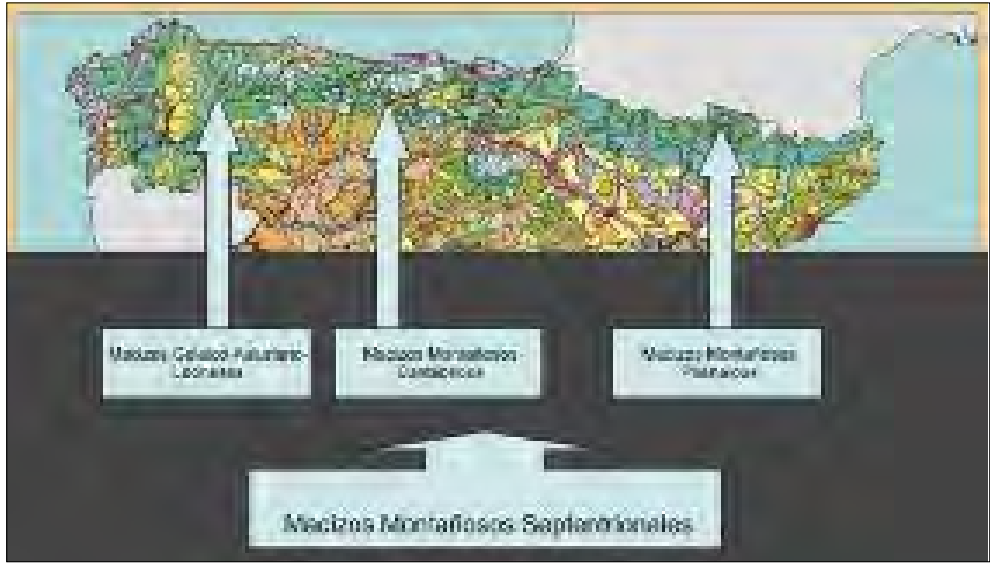

Detalle do mapa de asociacións de tipos de paisaxe

páramos e mesas, campiñas, chans interiores e litorais peninsulares, veigas e ribeiras, ou gargantas, desfiladeiros e foces, entre outros.

Fíxose tamén o mesmo exercicio de agregación e de síntese en cada arquipélago, aínda que, como xa se dixo, as súas dimensións reducidas, as especificidades que introduce cada elemento insular e a elevada diversidade interna de paisaxes, sobre todo no caso de Canarias, non sempre permitiu pasar de tipos a asociacións. En determinados casos, pois, os tipos de paisaxe constitúen o nivel superior da taxonomía paisaxística, tanto de Baleares como de Canarias. No caso balear ocorre iso, por exemplo, co tipo denominado «Serras béticas mallorquinas» e, en Canarias, cos tipos chamados «Dorsais e campos de lava recentes» ou «Cumes canarios». Tamén aconteceu isto cos tipos de paisaxe de base urbana identificados no Atlas -«Grandes cidades e áreas metropolitanas», "Cidades norteafricanas» e «Cidades canarias e o seu periurbano».

Preséntase no cadro que se xunta na páxina 155 desta obra un exemplo da taxonomía do Atlas, partindo dunha paisaxe -ou «unidade de paisaxe»-, neste caso, a Campiña cordobesa (54.10), que forma parte dun «tipo de paisaxe», o denominado Campiñas andaluzas -tipo número 54 do Atlas-, que se integra, asemade, nun conxunto maior, o das Campiñas, unha «asociación de tipos» que integra, xunto ás Campiñas andaluzas, as Campiñas da Meseta meridional, as da Meseta setentrional e as da Depresión do Ebro. 
CADRO 2

Exemplo da taxonomía do Atlas de los Paisajes de España

\section{RECORRIDO (METODOLÓGICO) POR LA DIVERSIDAD DE LOS PAISAJES DE ESPAÑA}

ASOCIACIÓN DE TIPOS DE PAISAJE “CAMPIÑAS” (incluye 4 Tipos de paisaje):

- 51. Campiñas de la Meseta septentrional

- 52. Campiñas de la Depresión del Ebro

- 53. Campiñas de la Meseta meridional

- 54. Campiñas andaluzas

TIPO DE PAISAJE: “54. CAMPIÑAS ANDALUZAS” (incluye 21 unidades de paisaje en 3 subtipos):

- Campiñas olivareras

- Campiñas cerealistas

- Campiñas de viñedo y olivar

UNIDAD DE PAISAJE: “54.10 Campiña cordobesa”

\section{NOMEAR AS PAISAXES: A NOMENCLATURA DAS PAISAXES DE ESPAÑA}

Como xa se dixo na presentación dos distintos niveis da taxonomía, déuselle unha grande importancia á forma de nomear as paisaxes, é dicir, ás denominacións, tanto dos tipos e asociacións, como, sobre todo, das pezas básicas da diversidade paisaxística de España, as unidades de paisaxe. Os nomes deben, de feito e ata onde sexa posible, expresar e localizar xeograficamente cada configuración paisaxística. Optouse así por denominacións sinxelas -breves, claras e comprensibles- e expresivas da identidade e a localización de cada paisaxe. A toponimia supón, nese sentido, un elemento fundamental da expresión cultural da paisaxe, polo que se fixo un uso considerable dela. En numerosas ocasións, sobre todo en paisaxes de longa historia e intensamente humanizadas, utilizouse a denominación de comarcas tradicionais para nomear paisa- 
xes, na medida en que parte da vella toponimia comarcal se refire a cadros paisaxísticos diferenciados de parecida escala aos que aparecen identificados neste Atlas e, tamén, a representacións paisaxísticas colectivas para os que os habitan e os visitan.

Non obstante, o elevado número de unidades que compoñen o mosaico de paisaxes esixiu un esforzo notable para nomealos axeitadamente. Mesmo foi preciso volver sobre nomes previamente adoptados, a medida que novas unidades e denominacións se incorporaban ao repertorio.

Sinteticamente, as denominacións adoptadas están baseadas nos elementos seguintes:

- Elementos do relevo: o relevo é, como xa se viu, un compoñente fundamental que lle outorga volume e forma física á paisaxe, e que, implicitamente, contén tamén indicios da organización humana do espazo. Trátase, pois, dun elemento esencial de discriminación fisiográfica nun territorio fortemente compartimentado como o da Península Ibérica e os arquipélagos. Son moi utilizadas, xa que logo, palabras como serras, macizos, cerros, páramos, depresións, chairas ou vales, así como outras denominacións vernáculas, de amplo eco rexional ou comarcal, como hoyas, concas, planas, lomas, muelas, turons, etc. Así mesmo, ás veces utilízanse tamén termos científicos que designan formas do relevo, pero que foron incorporados xa á linguaxe común de amplos sectores da poboación: por exemplo, penechairas, fosas, rasas ou glacis.

- Palabras que cualifican e matizan denominacións do relevo: trátase de aspectos que adoitan ter unha expresión significativa e visible na paisaxe, sobre todo nas súas formas e cores ou na súa localización xeográfica, e, indirectamente, nas características da cuberta vexetal e dos usos do solo. A natureza litolóxica do substrato é empregada como adxectivo cando está presente na forma e aparencia da paisaxe: fálase, por exemplo, de penechaira cuarcítica ou de serra cuarcítica, de chaira areosa ou de páramo detrítico. Cualificativos referidos á posición xeográfica que, pola súa parte, informan sobre a situación da unidade en relación con outros elementos físicos e, implicitamente, sobre diversos trazos da paisaxe derivados da humidade, a continentalidade ou a propia configuración da escena paisa- 
xística: ese é o sentido de cualificativos como costeiro e interior, xunto a serras ou a chans, ou de occidental, oriental e central, cualificando tamén distintas formas do relevo.

- Ribeiras e formacións palustres: aínda que non se realizou un tratamento específico e singular das ribeiras, son sempre elementos que considerar en relación coas paisaxes en que están enclavadas, de maneira que mesmo poden ser utilizadas para nomear as paisaxes en que se atopan, por exemplo: mariñas, arribes, ribeiras, litorais, deltas, marismas, etc.

- Os cultivos agrícolas: en moitas paisaxes, pero sobre todo nas construídas sobre relevos suaves, de maior potencial agrolóxico, os cultivos contribúen decisivamente a configurar a imaxe da paisaxe e a atribuírlle a súa marca principal de identidade. É sobre todo neses casos cando un cualificativo especificamente agrícola se utilizou para enriquecer e diferenciar as denominacións da forma física da paisaxe, que, xustamente nas paisaxes de maior peso agrario, ten nomes que, na linguaxe común, evocan, asemade, un determinado tipo de relevo e unha forma de cultivo e aproveitamento: así ocorre con campiña, veiga e, mesmo, con chan e páramo. É precisamente nestes casos cando, con maior profusión, se utilizaron os cualificativos agrícolas. Fálase así, por exemplo, de campiña oliveira de..., penechaira adevesada de..., ou de val vitícola de...

Estas denominacións e este particular emprego dos cualificativos agrícolas responden ademais a unha concepción da paisaxe que caracteriza a proposta de identificación paisaxística que contén este Atlas, ás diferentes escalas de traballo utilizadas. Ningún dos tres niveis da taxonomía, nin as asociacións de tipos, nin os tipos, nin sequera as paisaxes ou as unidades de paisaxe se confunden ou se identifican exclusivamente con ou a partir dos usos do solo. Quíxose evitar, conscientemente, unha tendencia bastante estendida nos exercicios de caracterización e cartografías de paisaxes a escalas medias e grandes, baseada, de forma exclusiva ou principal, nos chamados usos do solo -en puridade, coberturas vexetais naturais e agrícolas. Iso non supón, en modo ningún, negar a importancia que teñen os cultivos e formacións vexetais non agrícolas na configuración das paisaxes, pero si, pola contra, unha posición conceptual e metodolóxica que fundamenta a 
identidade e o carácter da paisaxe, tanto nos seus aspectos formais como perceptivos, nas relacións que se establecen entre a estrutura física do espazo xeográfico e outros compoñentes, naturais e humanos, entre eles, os usos do solo; en definitiva, a opción por unha idea de paisaxe como unha realidade obxectiva e percibida máis complexa que a expresión territorial das formacións vexetais naturais e os cultivos agrícolas.

- Urbanización e paisaxe: á escala de traballo seguida, só algunhas cidades e os seus tecidos metropolitanos chegan na Península a definir formal e funcionalmente paisaxes de claro dominio urbano. Os seis casos identificados foron nomeados coa cidade central e a súa área metropolitana. Só no caso de Bilbao, o especial significado morfolóxico e funcional da Ría foi incorporado á denominación da paisaxe, aínda que os seus límites superan o ámbito físico da ría e o seu contorno. En Canarias, o espazo das cidades capitais, ao que, no caso de Santa Cruz de Tenerife, se une La Laguna e os seus respectivos periurbanos, foi considerado a escala insular de suficiente entidade como para definir e, xa que logo, nomear paisaxes de natureza urbana. Singular resulta o caso dos territorios norteafricanos de Ceuta e Melilla, nos que a planta e a escena urbana de ambas as dúas cidades e dos seus suburbios, sobre particulares espazos físicos, foron esenciais para identificar e caracterizar as dúas paisaxes e as súas denominacións.

- Os nomes de lugares: por obvias razóns de identificación e localización, son adoptados nomes xeográficos de lugares -cidades, vilas, comarcas, paraxes, ríos, montañas- na maioría das denominacións das paisaxes. Cando se recorre a nomes de vilas e cidades, faise coa intención de referir a paisaxe en cuestión a un núcleo de poboación destacado ou significativo, forme ou non parte de denominacións xa acrisoladas: fálase así, por exemplo, de Huerta de Murcia, de Hoya de Baza, de Cuenca de Barberá ou de Llanos de Albacete, pero tamén de denominacións pouco habituais ou ad hoc, aínda que, segundo os autores, de claro significado paisaxístico: por exemplo, "Cerros y lomas al sur de Morón de la Frontera», «Penillanuras de Ledesma», «Campiñas de la Tierra de Almazán» ou «Rasa de Colombres». Cando se utilizan dous nomes de núcleos, en xeral é coa intención de acoutar aproximadamente os límites espaciais da paisaxe -«Vega y valle del Jiloca entre 
Calatayud y Calamocha»- ou de destacar a presenza de dúas poboacións importantes na identificación da paisaxe -«Campiña vitícola de Méntrida y Navalcarnero».

\section{UNHAS NOTAS FINAIS SOBRE O MÉTODO DE TRABALLO: AS FONTES, O TRABALLO DE CAMPO E O ARQUIVO FOTOGRÁFICO DAS PAISAXES DE ESPAÑA A PRINCIPIOS DO SÉCULO XXI}

As tarefas de identificación e caracterización das paisaxes de España, nos diferentes niveis da taxonomía proposta, están sustentadas, por unha parte, nunha abundante documentación cartográfica, bibliográfica, estatística e documental, tratada paisaxisticamente. Por outra, foi tamén moi importante o traballo de campo que, en bastante máis dun cento de xornadas e desenvolvido sempre conxuntamente por varios membros do equipo de autores, resultou decisivo nas operacións de delimitación e caracterización morfolóxica e visual, e permitiu contar cun importante material gráfico fundamental no documento finalmente elaborado: un repertorio fotográfico, se non completo, si bastante exhaustivo, intencionado e adecuadamente territorializado das paisaxes de España e das súas dinámicas a comezos do século XXI.

Sinteticamente, as «fontes cartográficas e imaxes» nas que se sustenta o traballo de identificación e caracterización de paisaxes son as seguintes:

- Imaxes de satélite de escala 1:100.000, editadas polo Ministerio de Obras Públicas.

- Mapas topográficos provinciais de escala 1:200.000, do Instituto Geográfico Nacional e, para os arquipélagos e para o estudo dos exemplos de paisaxes seleccionadas, mapas topográficos de escala 1:50.000, tanto do IGN como do Servicio Cartográfico del Ejército.

- Cartografías temáticas, de variadas escalas, segundo cada caso -maioritariamente, 1:200.000, 1:100.000 e 1:50.000 ou 1:25.000-: Mapa de cultivos e aproveitamentos, Mapa xeolóxico, Mapa forestal de España, cartografía dos Inventarios Forestais Provinciais, xunto a mapas topográficos e temáticos dalgunhas comunidades autónomas con produción cartográfica propia. 
- Cartografía emanada de documentos de ordenación do territorio, publicados e inéditos, de ámbitos autonómico e subautonómico.

A «bibliografía paisaxística» ou, máis propiamente, a de interese para a identificación e caracterización das paisaxes de España é, como pode supoñerse, amplísima. A máis profusamente utilizada na identificación e descrición de paisaxes e tipos de paisaxes acompaña os capítulos respectivos. Cómpre destacar, non obstante, que así como as diferenzas de escala motivan un distinto contido e diferente presentación da caracterización de tipos e de unidades de paisaxe, concretamente dos exemplos integrantes do capítulo VII, tamén é distinta a natureza da bibliografía útil para cada unha das tarefas. Para a caracterización dos tipos acudiuse principalmente á literatura temática ou territorial de ámbitos estatal e autonómico; para as paisaxes, as fontes principais de información foron as monografías locais e comarcais, cando as había, os estudos específicos sobre aspectos naturais e culturais da paisaxe, e, nun número significativo de casos, a información proporcionada por páxinas web especializadas e de calidade contrastada.

Ademais da literatura especializada e outra documentación de interese, resultaron tamén moi útiles os xuízos e as críticas dos expertos en paisaxe, nacionais e internacionais, que participaron no seminario convocado polo Ministerio de Medio Ambiente en decembro de 2000, no marco do Convenio subscrito entre a Universidad Autónoma de Madrid e o propio ministerio para a realización do Atlas. A intervención de expertos das comu nidades autónomas no seminario contribuíu tamén, en certa medida, a coñecer, por riba de opinións especializadas, as súas particulares visións e representacións das paisaxes que lles son próximas; unha vía de indagación paisaxística sustentada na participación das poboacións e os axentes locais, que, dada a escala de traballo e o obxectivo prioritario de proceder á cobertura sistemática de todo o ter ritorio, foi imposible abordar nesta ocasión.

Sen un traballo de campo abundante, coidadosamente preparado, de intencionalidade paisaxística e formulado sempre como unha tarefa colectiva dos autores, non se podería realizar esta caracterización das paisaxes de España. O traballo de campo, planificado habitualmente en campañas de tres a seis días e desenvolvido por grupos de entre tres e seis membros do equipo de investigación, foi concibido para acadar os obxectivos seguintes: 
- Verificar sobre o terreo a delimitación correcta das unidades resultantes da análise cartográfica de gabinete.

- Establecer os caracteres que definen a unidade interna de paisaxes e tipos de paisaxe: homoxeneidade, mosaico estrutural, singularidade, etc.

- Detectar as dinámicas recentes e as tendencias observables.

- Identificar elementos significativos e destacados da percepción e da visión da paisaxe, coñecer observatorios e miradoiros con potencial importante de vistas e itinerarios e corredores de especial interese e riqueza visual. Neste campo, nin os obxectivos nin as posibilidades materiais da tarefa encomendada permiten formular repertorio ningún de fitos, atalaias e miradoiros. Así e todo, o traballo de campo de intencionalidade paisaxística si que fixo posible, sobre todo na análise dos casos tratados no capítulo VII, unha aproximación aos recursos visuais das paisaxes estudadas.

- Tomar contacto, de xeito informal, con axentes locais, implicados e coñecedores das tendencias recentes da paisaxe, cuxas informacións resultaron sempre moi útiles para interpretar os procesos observables a través das formas da paisaxe, das estatísticas e da literatura experta.

- Debater sobre o terreo, entre investigadores con perfís disciplinares distintos, os criterios, a natureza e a interpretación das paisaxes identificadas.

- Constituír un arquivo fotográfico expresivo da diversidade e identidade das paisaxes, dos distintos planos e elementos que integran a súa visión e dos procesos que interveñen nos cambios paisaxísticos recentes.

$\mathrm{O}$ «repertorio fotográfico» das paisaxes españolas, resultante dos traballos de campo realizados, ilustra en boa medida, xunto a outros materiais dos autores e unhas poucas imaxes achegadas por outros expertos, o Atlas de los Paisajes de España. Pretendeuse, e en boa medida penso que se conseguiu, nos tres niveis da taxonomía, facilitar imaxes de moi distintas paisaxes e visións e planos igualmente diferentes. Na ilustración das asociacións pódense observar, fundamentalmente, panorámicas amplas de paisaxes que forman parte de cada un dos tipos que integran a asociación. As fotografías do capítulo dedicado aos tipos de paisaxe ilustran a variedade de subtipos que integran ese nivel intermedio da taxonomía, ofrecendo na meirande parte dos casos, e sempre que foi posible, visións amplas, é dicir, panorámicas ou planos medios, expresivos das estruturas 
paisaxísticas que constitúen o tipo. Finalmente, acompañando as fichas das paisaxes tratadas en detalle, figuran tres imaxes, a través das que se intentan combinar planos -adoitase ofrecer unha panorámica- con configuracións e elementos característicos ou singulares, que forman parte da descrición do texto.

En calquera caso, o Atlas optou conscientemente polo material fotográfico dos autores, mesmo sacrificando a calidade profesional ou a espectacularidade de visións aéreas oblicuas ou verticais. E procedeuse así por dúas razóns de orde metodolóxica. En primeiro lugar, porque as imaxes fotográficas nunha obra desta natureza non son meras ilustracións senón unha parte substancial do seu discurso e da súa argumentación; as fotos están, pois, tomadas coa finalidade explícita de identificar, caracterizar e transmitir as imaxes da paisaxe. En segundo lugar, porque as imaxes facilitadas responden a visións habituais e, na meirande parte dos casos, facilmente accesibles da paisaxe, obtidas desde onde as paisaxes adoitan verse, é dicir, desde a terra, xa sexa desde atalaias ou miradoiros institucionalizados, desde outros puntos panorámicos, desde percorridos habituais, ou desde as inmediacións dun elemento ou un patrón característico ou excepcional da paisaxe. 


\section{BIBLIOGRAFÍA}

Axencia Europea do Medio Ambiente: «Los paisajes», en Medio Ambiente en Europa. El Informe Dobrís, capítulo 8, Madrid, Ministerio de Medio Ambiente (edición española), 1998.

BASTIAN, O. e M. RÖDER: «Assessment of landscape change by land evaluation of past and present situation", Landscape and Urban Planning, 41, 1998, p. 171-182.

Berdoulay, V. e M. Phipps (dir.): Paysage et système, Ottawa, Éditions de l'Université d'Ottawa, 1985.

BESSE, J. M.: «Voir la Terre. Six essais sur le paysage et la géographie», en Actes du Sud ENSP/Centre du Paysage, 2000, p. 161. [Biblioteca Nueva prepara edición en castelán].

BRUNET, P. (dir.): L'Atlas des paysages ruraux de France, Paris, Éditions Jean-Pierre de Monza, 1994.

BRUnET-VInCK, V.: Méthode pour des Atlas de paysages. Enseignements méthodologiques de 10 ans de travaux, Paris, Ministère de l'Environnement et le Développement Durable, 2004, p. 127.

Candela de Fonseca, J. P. e A. Drach: «Un modèle spatio-dinamique du paysage», en V. Berdoulay e M. Phipps (dir.): Paysage et système, Ottawa, Éditions de l'Université d'Ottawa, 1985, p. 103-112.

CEPAGE: Enseigner le paysage, Bourdeaux, CEPAGE-École d'Architecture du Paysage de Bourdeaux, 2004, p. 40.

Claval, P.: Geografía humana y económica contemporánea, Madrid, Akal, 1987.

Comisión EuRopeA: Estrategia Territorial Europea, Luxemburgo, Oficina de Publicacións Oficiais das Comunidades Europeas, 89, 1999.

Consello de Europa: Convenio Europeo del Paisaje, 2000.

Consell Insular de Menorca: Plan Territorial Insular de Menorca, Maó, 2 vols., 2003.

Countryside Commission: Landscape Assessment Guidance, Chetelham, Countryside Commission, 1993.

Countryside Commission: Countryside Character. The Character on England's natural and man-made landscape, London, Countryside Commission, vol. 3, Yorkshire \& The Humber, 1998.

Countryside Commission for Scotland: Landscape Assessment: Principles and Practices, Battleby, Perth, 1992.

EEA-European EnVironment Agency: European Landscapes. Classification, Evaluation and Conservation (draft), EEA Environmental Monographs 3, 1998.

FELTZ, C.: Les territoires paysagères de Wallonie, Namur, Ministère de la Région Wallonne, 2004, p. 68.

Forman, R. T. T.: Land Mosaics: The Ecology of Landscapes and Regions, Cambridge, Cambridge University Press, 1995, p. 632.

Gadant, J. (dir.): L'Atlas des forêts de France, Paris, Éditions Jean-Pierre de Monza, 1994.

Gómez Mendoza, J. (dir.): Los paisajes de Madrid. Naturaleza y medio rural, Madrid, Alianza Universidad-Fundación Caja Madrid, 1999, p. 301.

GonZÁlez BernáldeZ, F.: Ecología y paisaje, Madrid, Blume, 1981.

HELmFrid, S.: Landscapes and Settlements (National Atlas of Sweden), Stockolm, SNA, 1994.

LuginbÜHL, Y.: Methode pour des atlas de paysages, Paris, Direction de l'Architecture et de l'Urbanisme, Strates/CNRS-SEGESA, 1994.

Martínez de Pisón, E.: «Cultura y ciencia del paisaje», Agricultura y Sociedad, 27, 1983, p. 9-32.

MARTíneZ de Pisón, E.: «El paisaje: el punto de vista geográfico», Ecosistemas, 6, 1993, p. 32-35.

MARUSIC, J. (dir.): Regional Distribution of Landscape Types in Slovenia. Methodological Bases, National Office for Physical Planning, Republic of Slovenia, 1998. 
Mata Olmo, R.: «Paisajes y sistemas agrarios españoles», en C. GÓmez Benito e J. J. GonzÁlez RodríGUEZ (ed.): Agricultura y sociedad en la España contemporánea, Madrid, CIS-MAPA, 1997, p. 109-172.

MATA Olmo, R.: «Un concepto de paisaje para la gestión sostenible del territorio», en R. MATA OlMO e A. TARroja: El paisaje y la gestión del territorio. Criterios paisajisticos en la ordenación del territorio y el urbanismo, Barcelona, Diputació de Barcelona-CUIMP, 2006a, p. 17-40.

Mata Olmo, R.: «Desarrollo sostenible, insularidad y gobierno del territorio: la experiencia del PTI de Menoría», Boletín de la Asociación de Geógrafos Españoles, n. ${ }^{\circ} 41,2006 \mathrm{~b}$, p. 183-198.

Mata Olmo, R.: «Métodos de estudio del paisaje e instrumentos para su gestión. Consideraciones a partir de experiencias de planificación territorial», en R. Mata Olmo e A. Tarroja: El paisaje..., op. cit., 2006c, p. 199-239.

Mata Olmo, R. e S. Fernández Muñoz: «La Huerta de Murcia. Landscape guidelines for a Peri-urban territory», Landscape Research, 29, n. ${ }^{\circ}$ 4, 2004.

Mathewson, K.: "Cultural Landscapes and ecology, 1995-96: of oecumenics and nature(s)", Progress in Human Geography, 22 (1), 1998, p. 115-118.

Región de MurCiA: Análisis, diagnóstico y propuesta de directrices de paisaje del Area Metropolitana de Murcia (Huerta de Murcia y Vega Media), Murcia, Consejería de Obras Públicas y de Ordenación del Territorio, 3. vols., 2002.

Pérez-Chacón, E.: "Ciencia del Paisaje y ordenación territorial», en Ponencias II Congreso de Ciencia del Paisaje, Barcelona, Universitat de Bacelona y Fundación "la Caixa”, 1995, p. 31-58.

OlWING, K. R.: "Recovering the substantive Nature of Landscape», Annals of the Association of American Geographers, 86(4), 1996, p. 630-653.

Phipps, M. e V. Berdoulay: «Paysage, système, organisation», en V. Berdoulay e M. Phipps (dir.): Paysage et système, Ottawa, Éditions de l'Université d'Ottawa, 1985, p. 9-19.

Ravignan, F. DE e P. Roux : L'Atlas de la France Verte, Paris, Éditions Jean-Pierre de Monza, 1990, 345 p.

Robinson, D. G., I. C. Laurie, J. J. Wager e A. L. Traill: Landscape Evaluation, Manchester, University of Manchester, 1977.

SANTOS, M.: «De la société au paysage», Herodote, 9, 1978, p. 66-73.

SAnZ Herráiz, C.: Los paisajes naturales españoles. Caracteres propios y necesidades de conservación: su valor como recurso natural y cultural, Sevilla, Fundación Biodiversidad, 2002, p. 30.

SKANES, M. H.: «Towards an integrated ecological-geographical landscape perspective. A review of principal concepts and methods», Norsk Geogr. Tidsskr, 51, 1997, p. 145-171.

Schama, S.: Landscape and Memory, New York, Alfred A. Knopf, 1995.

Scottish Natural Heritage-The Countryside Agency: Landscape Character Assessment. Guidance for England and Scotland, 2002, p. 86.

SWANWICK, C.: "Recent practice and the evolution of Landscape Character Assessment», Landscape Character Assessment. Guidance for England and Scotland, The Countryside Agency and Scottish Natural Heritage, 2003a, p. 9.

SWANWICK, C.: «Techniques and Criteria for Judging Capacity and Sensitivity», Landscape Character Assessment. Guidance for England and Scotland, The Countryside Agency and Scottish Natural Heritage, 2003b, p. 19.

TERRADAS, J.: «El paisaje y la ecología del paisaje», en R. FOLCH (coord.): El territorio como sistema. Conceptos y métodos de ordenación, Barcelona, Diputació de Barcelona, 2003, p. 57-72. 
O ATLAS DAS PAISAXES DE ESPAÑA,

TÉVAR SANZ, G.: «La cuenca visual en el análisis del paisaje», Serie Geográfica, 6, 1996, p. 99-113.

The Countryside Agency-Scottish Natural Heritage: Landscape Character Assessment. Guidance for England and Scotland, 2002, p. 84.

The Countryside Agency-Scottish Natural Heritage: «Use of Geographical Information Systems and other computer methods", Landscape Character Assessment. Guidance for England and Scotland, Topic paper 4, 2003, p. 16.

WASCHER, D. M. (ed.): European Landscape Character Areas, Oxford, Landscape Europe, 2005, p. 148.

ZoIDO, F. e F. POSOCCO: «Política de paisaje: protección, ordenación y gestión», en J. ARIAS AbELLÁN e F.

FOURNEAU (ed.): El paisaje mediterráneo. Le paysage méditerranéen. Il paesaggio mediterraneo, Granada, Universidad de Granada-Junta de Andalucía, 1998, p. 155-166. 

Retruque

\section{XÉNESE E OCASO DAS PAISAXES NATURAIS DE GALICIA \\ Pablo Ramil Rego}

Universidade de Santiago de Compostela 



\section{INTRODUCIÓN: OS ESTUDOS E CLASIFICACIÓNS DAS PAISAXES DE GALICIA}

Poderiamos asumir que as primeiras tipoloxías da paisaxe galega quedan plasmadas nos petróglifos, onde os antigos poboadores de Galicia indicaban áreas reais ou imaxinarias de caza, distintos territorios e itinerarios. Os propios petróglifos, as medoñas e as pedras chantadas serviron e aínda se empregan como marcos xeográficos, como fitos nas principais vías que discorren polas nosas vellas paisaxes.

As primeiras referencias escritas das paisaxes galegas relaciónanse coa invasión e posterior ocupación romana. Os escritos describen vagamente o territorio e destacan os aspectos utilitaristas, así como os elementos discordantes cos usos e costumes da metrópole, coa evidente intención de xustificar a actuación de dominio e colonización.

Entre as descricións antigas da paisaxe da Gallaecia son sen dúbida as de Estrabón (63 a. de C.-19 d. de C.) as que máis regueiros de tinta xeraron entre os autores posteriores, entre outros Bermejo Barreira e García Quintela (Bermejo Barreira, 1979, 1982 e 1986; e García Quintela, 1999). A visión de Estrabón é puramente egocéntrica e utilitarista pero, a pesar diso, inclúe dous importantes escenarios que se manterán en todas as descricións xeográficas posteriores e que na actualidade seguen vixentes, a oposición do espazo ou paisaxe litoral -sublitoral fronte ao interior, entendido este como exclusivamente montañoso. A anteposición costa, val, chaira fronte á montaña será, xa que logo, un elemento clave non só na configuración dos compoñentes da paisaxe no tocante á súa xeografía ou cuberta vexetal, senón que imporá unha clara diferenza en relación á vida e organización social dos montañeses fronte aos que viven nas terras baixas e no litoral.

A montaña configúrase como o auténtico límite do Imperio; os atrancos para acceder a ela e, xa que logo, a súa maior dificultade para dominala e adminis- 
trala fan que Estrabón e outros autores clásicos incidan de forma moi xenérica nas peculiaridades da paisaxe montañesa e, sobre todo, nas peculiaridades de comportamentos dos belicosos montañeses.

O esquema analítico da paisaxe e do territorio descrito por Strabón manterase noutros autores clásicos e persistirá máis ou menos evidente ata a primeira metade do século XIX. Así, comparando as descricións de Molina (1550), coas de Padín (1849), percíbese un neto incremento da información sobre os compoñentes xeográficos, xeolóxicos, zoolóxicos, así como no tocante ás especies cultivadas e á estrutura de ocupación do territorio litoral-sublitoral, e que apenas hai información verbo da configuración das áreas de montaña. Por outra parte, as dificultades de acceso e o escaso coñecemento sobre moitas rexións de Galicia quedan patentes cando, en obras escritas na primeira metade do século XIX, como é o caso da historia de Padín (1849), se recollen integramente as vagas descricións, moitas veces impregnadas de mitos e lendas, da obra do licenciado Molina (1550), escrita trescentos anos antes.

A análise científica da paisaxe xorde con Alexander von Humboldt (1769-1859) e os seus discípulos. A influencia de Humboldt sobre a ciencia española e en particular sobre a galega é notoria. E un dos seus máis importantes seguidores é sen dúbida Víctor López Seoane (1834-1900). A Reseña de la Historia Natural de Galicia inclúe a primeira descrición científica da paisaxe galega. Posteriormente, o discípulo de López Seoane, o pai Baltasar Merino (1845-1910), rompe definitivamente coa ortodoxia naturalista do dezaoito e incorpora na súa célebre Flora de Galicia (1908) un apéndice sobre a paisaxe e a vexetación do territorio galego; "Ligeras indicaciones sobre la fitogeografía gallega», no que queda patente a dualidade entre a paisaxe mediterránea, cinguida ao Sil, e a atlántica, característica da maior parte de Galicia.

Os esbozos da paisaxe galega marcada por Merino (Merino, 1909) serán desenvolvidos posteriormente por Otero Pedrayo (Otero Pedrayo, 1926a, 1926b, 1927, 1928, 1959, e Otero Pedrayo et al., 1955) desde unha perspectiva fortemente xeográfica e humana. Otero Pedrayo nútrese das «rexións naturais» establecidas por Dantín Cereceda (Dantín Cereceda, 1922 e 1942), adecuándoas e conformándoas á realidade galega. A Otero Pedrayo débeselle a primeira delimitación das diferentes paisaxes culturais de Galicia e, asemade, afianza a descrición dos espazos de forte carácter natural, incluíndo unha secto- 
rización das unidades marítimo-costeiras, cinco sectores ou arcos, que aínda se emprega na actualidade. Mentres que a proposta para as áreas interiores quedou esvaecida polos brutais cambios sufridos a partir da segunda metade do século XX, Otero Pedrayo (1927 e 1928) executa unha descrición xeográfica sistemática da parroquia e da aldea e analiza os diversos tipos de asentamentos territoriais, integrándoos con diferentes tipos de unidades que hoxe designamos como agrosistemas.

Bellot Rodríguez establecerá as bases da moderna Xeobotánica, coa incorporación de técnicas paleoecolóxicas orientadas á análise histórica dos cambios da paisaxe, desenvolvendo ademais un importante labor na descrición das comunidades vexetais, é dicir, dos compoñentes teselares das paisaxes. Posteriormente, e seguindo igualmente o método sigmatista, Rivas Martínez (2005 e Rivas-Martínez et al., 1984 e 1987) e Izco (1987) abordarán novas propostas sobre os principais dominios e as unidades que conforman a paisaxe galega, aínda que sen propoñer unha formulación expresa de tipos e unidades paisaxísticas.

Desde o ámbito da Xeografía agraria, Bouhier (1979) formula unha ampla descrición dos sistemas de explotación agrícola do territorio galego. A análise de Bouhier peca en exceso de simplicidade pois reduce os tipos de agrosistemas indicados previamente por Otero Pedrayo (1926b, 1927 e 1928) a dez formas principais de organización agraria, esvaecendo a presenza territorial de importantes tipos de agrosistemas, como acontece coas áreas de montaña con gandaría extensiva, que aparecen irregularmente englobadas en agrosistemas tipo boca$g e$, cando son posuidoras de características territoriais, estruturais e produtivas claramente diferentes, e mostran elementos comúns cos agrosistemas de gandaría extensiva descritos noutros territorios da faciana atlántica europea.

$\mathrm{Na}$ década dos noventa, impúlsanse novas liñas de investigación da paisaxe, incorporando técnicas de reconstrución paleoecolóxica e de ecoloxía da paisaxe que levan a propoñer unha reformulación das unidades paisaxísticas, entendidas como elementos dinámicos, froito da interacción espazo-temporal de factores ambientais e antrópicos (Ramil Rego, 1993), integrando, xa que logo, a dinámica paisaxística no ámbito do cambio global, tanto a grandes escalas temporais, como en relación cos períodos recentes que discorren entre a ruralización do territorio galego marcada pola expansión do fenómeno castrexo, ata a degradación e desnaturalización das paisaxes que se produce ao longo do Antropoce- 
no (Díaz Varela, Ramil Rego e Calvo Iglesias, 2006; Fernández Rodríguez, Muñoz Sobrino, Ramil Rego e Gómez Orellana, 2002; Gómez Orellana et al., 2005-2006 e 2007; e Ramil Rego et al., 1998 e 2005).

No ano 2000, o Consello de Europa, reunido na localidade italiana de Florencia, elabora o Convenio Europeo da Paisaxe, que non será ratificado por España, como adoita acontecer coa maioría dos convenios internacionais relacionados co medio natural, ata o ano 2007. O Convenio Europeo da Paisaxe constitúe o primeiro acordo internacional que promove un marco político e xurídico común para a protección, xestión e o desenvolvemento sostible da paisaxe europea. Entre as novidades que achega o devandito convenio está a de propoñer a paisaxe como concepto integrador nas políticas de planificación e ordenación do territorio e dos recursos naturais, incorporándoa aos valores substantivos do proxecto de sociedade humanística que o Consello de Europa propón e defende desde a súa fundación. O Convenio Europeo da Paisaxe será integrado na lexislación galega a través da Lei 7/2008, do 7 de xullo, de Protección da Paisaxe de Galicia.

O Convenio da Paisaxe determina a necesidade de catalogar os tipos de paisaxes e, neste ámbito, o Ministerio de Medio Ambiente desenvolveu un ambicioso proxecto dirixido polos profesores Mata Olmo e Sanz Herráiz, que xerará a publicación do Atlas de los Paisajes de España (2003). Desde un punto de vista científico, a obra destaca por adecuar unha metodoloxía científica, baseada noutras experiencias europeas, para a identificación e clasificación das paisaxes, pero, non obstante, resulta pouco brillante no momento de delimitar e caracterizar estas, sobre todo nos territorios atlánticos ibéricos e en concreto en Galicia, que lle restan á devandita obra o seu valor de referencia que motivou a súa redacción.

No caso galego, os límites das unidades seguen en boa medida as descricións recollidas en autores anteriores, como Otero Pedrayo ou Dantín Cereceda, así como de autores contemporáneos, fundamentalmente Pérez Alberti (1986). Non obstante, a delimitación final das clases e tipos de paisaxes resulta moi insatisfactoria, e incumpre mesmo os criterios metodolóxicos previamente formulados, creando unidades totalmente artificiais, mentres que, pola contra, propón a división ou individualización de unidades que carecen de sentido bioxeográfico e paisaxístico. As deficiencias observadas na proposta de Mata Olmo e Sanz Herráiz (2003) leváronnos a efectuar unha nova sectorización das paisaxes de 
Galicia (Ramil Rego et al., 2005), mantendo a metodoloxía establecida no Atlas de los Paisajes de España, delimitando as unidades paisaxísticas a partir dunha información máis detallada e precisa dos seus compoñentes básicos e delimitando as catro clases e os vinte e un tipos de unidades de paisaxe de Galicia a escala $1: 5.000$.

\section{DINÁMICA DAS PAISAXES DE GALICIA}

O territorio galego, en triste sintonía co resto dos territorios atlánticos europeos, carece desde hai séculos de paisaxes prístinas. A acción humana, patente no noso territorio desde hai máis de cinco mil anos, supuxo a transformación das paisaxes prístinas en paisaxes naturais, tamén consideradas xeralmente como semi-naturais, xa que nelas aínda persistían elementos característicos das paisaxes e sistemas prístinos, xunto con novos elementos vinculados cos sistemas de explotación dos recursos. A expansión das paisaxes naturais coincide co crecente poboamento das Idades do Bronce e do Ferro, coa ruralización do territorio a través da aparición de poboados estables e fortificados, os castros. Posteriormente, sufrirán durante a Idade Media unha importante transformación vinculada ao establecemento do novo modelo produtivo impulsado pola Igrexa e a nobreza, para manterse sen apenas modificacións ata a primeira metade do século XX, en pleno desenvolvemento do Antropoceno (Crutzen e Stoermer, 2000).

As paisaxes naturais, forxadas na domesticación das paisaxes prístinas, deben considerarse tamén como paisaxes culturais, ao posuír notables valores culturais e etnográficos, tanto de carácter material como inmaterial. As paisaxes naturais pódense descompoñer en distintos agrosistemas, e estes, asemade, en tipos de hábitats. Os agrosistemas tradicionais caracterízanse por manter un equilibrio territorial e funcional entre os espazos forestais - silva-, as áreas de matogueira e afloramentos rochosos -saltus- e as áreas de uso agrícola -ager. Este equilibrio sustenta unha gran diversidade de hábitats e especies de flora e fauna silvestre, así como un número tampouco desprezable de variedades de plantas cultivadas e de razas gandeiras.

A partir da Revolución Industrial, o espazo agrario europeo experimenta unha progresiva e drástica transformación, que culminará na segunda metade do 
século XX coa instauración de modelos de explotación totalmente insostibles, tanto no ámbito ambiental, como no económico e social. As transformacións que vive a "Europa liberal» son similares e teñen as mesmas funestas consecuencias que as que se producen na «Europa socialista», e provocan a substitución das paisaxes naturais e dos agrosistemas tradicionais, por paisaxes e sistemas artificiais. En Galicia, como noutros territorios europeos, esta salvaxe transformación supón a ruptura do equilibrio existente entre silva, saltus e ager, que traerá como consecuencia unha importante afección sobre a biodiversidade e o patrimonio natural e cultural atesourado nos agrosistemas tradicionais e, xa que logo, un gran número de tipos de hábitats naturais, así como que centos de poboacións de especies de fauna e flora silvestre se atopen na actualidade ameazadas de desaparición. Xunto coa desaparición dos elementos silvestres, a agonía do espazo rural tradicional supuxo a perda, en moitos casos irrecuperable, dunha inxente cantidade de variedades e razas tradicionais, así como dun número tampouco desprezable de elementos relevantes do patrimonio cultural de Galicia. Fíxose todo iso para favorecer unha suposta modernidade, que provocou o éxodo masivo de agricultores e gandeiros e, xa que logo, o despoboamento de numerosos rueiros, aldeas ou mesmo de pequenas vilas.

$\mathrm{Na}$ triste historia da destrución da paisaxe tradicional de Galicia xorden distintos actores, aínda que entre eles aflora polo seu efecto destrutor a execución de fatídicos proxectos de colonización e concentración parceira auspiciados inicialmente polo afán produtivista do franquismo, que aínda, de forma anacrónica, manteñen a súa vixencia e formas de destrución na actualidade. As áreas concentradas perden todo vestixio de naturalidade, os elementos naturais, como as árbores, son desprezados, como o son tamén os muros, os chantos, os cruceiros ou os castros e as medoñas. Todo debe ser uniformado e homoxeneizado, co fin de favorecer a implantación do deserto de herba, extensas pradarías pauciespecíficas, constituídas xeralmente por tres especies sementadas e un cortexo máis ou menos amplo de elementos sinantrópicos e invasores, entre os que se intercalan parcelas igualmente monótonas de cultivos transxénicos, con métodos de explotación nos que o exceso de agroquímicos pon en xaque o carácter sostible do sistema. O novo ager avanza de forma corrosiva, degradando e uniformizando os eidos, cortiñas, agras e prados, labrados ao longo da historia rural de Galicia, destruíndo calquera vestixio ou elemento de importancia natural ou cultu- 
ral, mentres que é incapaz de absorber os seus propios residuos e necesita constantes achegas de insumos para poder manterse.

A homoxeneidade do ager solápase coa monotonía da silva, na que o eucalipto adquire vertixinosamente un papel dominante, cando non exclusivo, na maior parte do territorio galego; paisaxes costeiras dominadas por eucaliptais defoliados polo avance do Gonipterus; pedopugas (pseudotsuga) e piñeiros silvestres invadindo brañas e tremedais; piñeiros de Monterrei e marítimo crecendo con total impunidade sobre as dunas grises e as dunas remontantes; acacias e mimosas devorando as bocarribeiras. Mentres que as fragas, carballeiras, reboleiras, aciñeiras, sobreirais e bidueirais agonizan baixo o «rouco son» da motoserra.

O saltus é a paisaxe por antonomasia de Galicia. A súa fisionomía, que marcou durante a maior parte do Cuaternario o tapiz vexetal galego e foi sustento esencial para os agrosistemas tradicionais, é agora un elemento proscrito, malia a súa consideración como hábitat de interese comunitario. Para a Administración é simple biomasa residual dun sistema manifestamente mellorable, aínda que as melloras sen sentido só xeran maior gasto económico e maior pegada ecolóxica.

Monte tras monte, serra tras serra, val tras val, a perda da paisaxe natural galega progresa incesantemente. E no avance das paisaxes artificiais incorpóranse novos elementos froito da voracidade especuladora que afoga os profundos vales e canóns para exportar enerxía fóra das nosas fronteiras, e transforma os cumios en cemiterios de ferralla, marañas de tendidos eléctricos e labirintos de pistas. Existe tamén unha xenuína paisaxe artificial propiciada polo Plan de Costas que deixa a súa pegada permanente de formigón, madeira, aceiro inoxidable e especies invasoras nas dunas, acantilados e brañais do litoral, e crea unha muralla de pésimo gusto entre a ría de Ribadeo e o esteiro do Miño. Estas formulacións foron exportadas con total impunidade aos cursos fluviais, promovendo a súa canalización e a degradación das súas ribeiras.

A destrución da paisaxe galega non é allea ao fenómeno do «ladrillazo», manifestación da desorde urbanística que atopou forte arraigamento nas áreas costeiras, transformando sistemas de dunas, acantilados ou brañais costeiros, nunha amálgama aberrante de ladrillo e modernidade, equiparable, a menor escala, aos modelos máis abominables e insostibles que imperan nas áreas máis especulativas da costa mediterránea. A epidemia estendeuse cara ao interior, e así 
os terreos de concentración, que en anos previos sustentaron agrosistemas tradicionais, son agora edificados, sen gardar unha mínima relación cos primitivos núcleos rurais. $\mathrm{O}$ «ladrillazo» adquire en Galicia tinguiduras pintorescas, que inclúen desde as aberrantes colonias de "persiana baixada», que circundan os principais centros de atracción turística e as neourbes dormitorio, ata o "ladrillazo» con pedigree, froito da desbordante e descontrolada creación de alucinados profesionais que non teñen reparo en deixar unha pegada permanente e aberrante sobre a paisaxe.

Pero de todos os modelos de «ladrillazo» presentes en Galicia, o máis xenuíno é o galpón, que, integrado na política do «ti vai facendo», provoca a agonía de amplas áreas do territorio litoral e sublitoral, chegando a conformar extensos poboados de favelas, exemplos alarmantes de insostibilidade territorial e ambiental.

A conservación da paisaxe galega atópase nun momento crucial, talvez diante da última oportunidade para preservar aqueles retallos e elementos que durante o devir histórico marcaron e configuraron unha parte esencial da identidade de Galicia. E por iso as clasificacións das paisaxes deben cubrir, ademais dos formalismos sistemáticos, aspectos fundamentais ligados ao estado de conservación destes, á calidade paisaxística de cada territorio, a avaliar obxectivamente a incidencia a curto e medio prazo tanto dos plans e actuacións destrutoras, como a eficacia dos sistemas legais e de xestión establecidos para asegurar a súa conservación con medidas lexislativas e administrativas para o uso racional e sostible da paisaxe. 


\section{BIBLIOGRAFÍA}

Bermejo Barrera, J. C.: «Tres notas sobre Estrabón: Sociedad, Derecho y Religión en la cultura castreña», Gallaecia, 4, 1979, p. 1-97.

Bermejo Barrera, J. C.: Mitología y mitos de la Hispania Prerromana, I, Editorial Akal, Madrid, 1982.

Bermejo Barrera, J. C.: Mitología y mitos de la Hispania Prerromana, II, Editorial Akal, Madrid, 1986.

BouHier, A.: La Galice. Essai geographique d'analyse et d'interpretation d'un vieux complexe agraire, La Roche-sur-Yon, 1979.

Crutzen, P. J. e E. F. Stoermer: "The "Anthropocene”", Global Change Newsletter, 41, 2000, p. 17-18.

DANTÍN CERECEDA, J.: Ensayo acerca de las regiones naturales de España, Madrid, 1922.

Dantín Cereceda, J.: Regiones naturales de España, Madrid, 1942.

Díaz Varela, R. A., P. Ramil Rego e M. S. Calvo Iglesias: «Identification and categorization of linear disturbances in Corrubedo natural park (NW iberian peninsula)", ISPRS Archives, 35, 2006, p. 1-6.

Fernández Rodríguez, C., C. Muñoz Sobrino, P. Ramil-Rego e L. Gómez Orellana: «Historia ecológica de Galicia: modificaciones del paisaje a lo largo del Cenozoico", Semata, 13, 2002, p. 67-104.

García Quintela, M. V.: Mitología y mitos de la Hispania Prerromana, III, Editorial Akal, Madrid, 1999.

Gómez Orellana, L., P. Ramil Rego, C. Muñoz Sobrino e M. J. Iriarte Chiapusso: «Cambio climático y dinámica temporal del paisaje y de los hábitats en las ecorregiones del NW de la Península Ibérica durante el Pleistoceno superior», en MunibE: Antropología y arqueología. Homenaje a Jesús Altuna, 2005-2006, p. 537-551.

Gómez Orellana, L., P. Ramil Rego e C. Muñoz Sobrino: «The Würm in NW Iberia, a pollen record from Area Longa (Galicia)», Quaternary Research, 67, 2007, p. 438-452.

Huerta y Vega, F. X. DE la: Anales de el Reyno de Galicia, 2 vol., Santiago de Compostela, 1733-1736.

Izco, J.: "Galicia», en M. Peinado e S. Rivas Martínez (ed.).: La Vegetación de España, Universidad de Alcalá, Alcalá de Henares, 1987.

López Seonne, V.: Reseña de la Historia Natural de Galicia, Imprenta Soto Freire, Lugo, 1866.

Martínez de Padin, L.: Historia política, religiosa y descriptiva de Galicia, Madrid, 1849.

Mata Olmo, R. e C. Sanz Herráiz (dir.): Atlas de los Paisajes de España, Madrid, 2003.

MedinA, P. DE: Libro de las grandezas y cosas memorables de España, Madrid, 1549.

Merino, B.: Flora de Galicia, t. III, Santiago de Compostela, 1909.

Molina, B. S. DE: Descripción del Reyno de Galicia y de las cosas notables del Autor, Madrid, 1675.

Otero Pedrayo, R.: Guía de Galicia, Galaxia, Vigo, 1926a (primeira edición).

Otero Pedrayo, R.: Sintesis xeográfica de Galicia, Seminario de Estudos Galegos, 1926b.

Otero Pedrayo, R.: Problemas de Xeografía Galega. Estudos encol das formas de poboación labrega. A parroquia de Trasalva, Nós, 1927.

Otero Pedrayo, R.: Paisajes y problemas geográficos de Galicia, Biblioteca de Estudios Gallegos, Madrid, 1928.

Otero Pedrayo, R.: «En busca de una fórmula del paisaje gallego», Vida Gallega, 49, 1959.

Otero Pedrayo, R. et al: Paisaxe e cultura, Galaxia, Vigo, 1955.

Pérez Alberti, A.: A Xeografía, Galaxia, Vigo, 1986.

RAMIL Rego, P.: «Historia de la vegetación y evolución climática durante el Pleistoceno Superior y el Holoceno, en las regiones montañosas del Noroeste Ibérico", en A. PÉrez AlberTi, P. RAMIL-REgo e L. GuI- 
TIÁN RIVERA (ed.): La evolución del paisaje en las montañas del entorno de los Caminos Jacobeos, Santiago de Compostela, 1993.

Ramil Rego, P., C. Muñoz Sobrino, M. A. Rodríguez Guitián e L. Gómez Orellana: «Differences in the vegetation of the North of the Iberian Peninsula during the last 16,000 years», Plant Ecology, 138, 1998, p. 41-62.

Ramil Rego, P. et al:: «La expresión territorial de la biodiversidad. Paisajes y hábitats», Recursos Rurais Cursos e Monografias, 2, 2005, p. 109-128.

Rivas MartíneZ, S. (dir.): Mapa de series, geoseries y geopermaseries de vegetación de España. Manuscrito, Phytosociological Research Center, Madrid, 2005.

Rivas Martínez, S., T. E. Díaz, J. A. Fernández-Prieto e A. Penas: La vegetación de la alta montaña cantábrica: Los picos de Europa, Ed. Leonesas, León, 1984.

Rivas Martínez, S. e J. M. GÁndullo: Memoria del Mapa de Series de Vegetación de España 1:400.000, Serie Técnica, ICONA, Madrid, 1987. 


\section{PASADO E PRESENTE DA PAISAXE. DO DISCURSO DA PAISAXE ÁS PAISAXES SEN DISCURSO}



Relatorio

\section{PAISAXE E IDENTIDADE NO DISCURSO GALEGUISTA}

Caroline Domingues

Université Blaise-Pascal de Clermont-Ferrand 

De Manuel Murguía a Castelao, a paisaxe de Galicia representa na identidade galega un elemento clave para identificar e diferenciar. Identifícase cos países celtas e o norte de Portugal; diferénciase coa seca Meseta castelá. Os teóricos do galeguismo trataron o tema da paisaxe alén da súa dimensión puramente xeográfica, como un elemento central da personalidade galega, elemento a partir do que se desenvolveron unha estética, unha cultura, unha organización política, e mesmo un carácter galego identificable e único. Segundo eles, a paisaxe é civilización, fonte de poesía, de literatura e de expresión artística.

O propósito deste traballo é analizar este tema esencial da galeguidade co apoio de dúas obras clave do pensamento nacionalista galego: Teoría do nacionalismo galego, de Vicente Risco, e Sempre en Galiza, de Castelao, pero incorporarei tamén ensaios e artigos destes dous intelectuais e outras achegas de diferentes personalidades do galeguismo.

Veremos que a paisaxe galega, lugar das orixes, se converte en «templo» da memoria ata ser, en Castelao, un xardín de Edén, que aspira a recobrar a idade de ouro das súas orixes. Examinaremos as dimensións cultural e estética da paisaxe, berce da creación artística. Analizaremos como a paisaxe representa un dato imprescindible na construción dunha identidade persoal, artística e colectiva e como, no caso galego, participa na definición da identidade e lle serve de fundamento á ideoloxía política.

Todas as preguntas verbo da paisaxe coinciden para definilo como obxecto e, asemade, como suxeito. A paisaxe revélase, en efecto, «nunha experiencia en que suxeito e obxecto son inseparables», precisa Michel Collot (1995, p. 211). Fálase, ás veces, de diálogo entre o sitio natural e a intervención humana, xa que a ordenación do terreo traduce, de maneira singular, a reciprocidade entre o cultural e o natural. Segundo o xeógrafo americano John Brinckerhoff Jackson (2003, p. 11-12), a paisaxe é «unha sucesión de pegadas, de marcas que se sobrepoñen no chan. Neste sentido, é como unha obra de arte; a terra, o solo, a natu- 
reza son os materiais usados e organizados polos homes segundo valores culturais. Estes son diferentes no tempo e no espazo» ${ }^{1}$. Para este mesmo autor, a paisaxe é «a encarnación do espírito dunha cultura, dos seus valores e aspiracións [...]. Neste sentido, a paisaxe é como un traxe de humanidade posto no solo. A actividade humana inscríbese no solo e transfórmao» (Jackson, 2003, p. 18-19). Así, a paisaxe é unha marca cultural da natureza. É, asemade, un espazo natural, cultural e social. Trátase, segundo a definición de Anne Sgard, da manifestación sensitiva da inscrición dunha sociedade no seu marco de vida (Sgard, 1997). A paisaxe desempeña un papel de «mediadora» na relación entre os habitantes e o territorio, e aparece como un dato esencial do vínculo afectivo e estético que o habitante mantén con ese mesmo territorio e que participa da súa apropiación. Ao evocar Andalucía, Yves Luginbühl precisa que só se lles chama paisaxes aos espazos que presentan unha capacidade de seren idealizados ou de procuraren o benestar; as inmensas parcelas de cereais non constitúen unha paisaxe para a maioría dos habitantes, que consideran estas chairas só como un espazo de traballo (Collot, 1995, p. 323). A ocupación tradicional do territorio en Galicia e a súa transformación en paisaxe cultivada como un xardín, e non para o proveito dunha industria agrícola, ofrece así a visión dun intercambio constante e permanente e dunha comuñón perenne entre home e natureza.

Para os investigadores en Etnoxeografía, o territorio non é só «un fragmento de espazo que o grupo se apropia [...], é tamén o punto de fixación no que arraigan os valores e no que se confirma a identidade dunha comunidade. Esta identidade confúndese co territorio, terra nutricia material e espiritual [...]. Hai así unha relación esencial entre o territorio recoñecido como tal por un grupo e a identidade que se constrúe e que o constrúe» (Collignon, 1999, p. 93). No caso das sociedades agrarias fortemente arraigadas no tempo e no espazo, como Galicia, a paisaxe confúndese co espazo de produción e co espazo vivido de maneira cotiá (Bertrand, 1995, p. 103-104). En Galicia, a paisaxe pon en escena a historia cotiá; é o teatro do ordinario. Esta combinación das escalas temporais, espaciais e sociais converten a paisaxe nun dos soportes privilexiados da identidade colectiva (Sgard, 1997). Na procura da identidade, a

\footnotetext{
${ }^{1}$ Toda paisaxe, en certa maneira, é relativa a un proxecto, aínda que este non sexa "consciente», aínda que sexa o reflexo inconsciente da organización dunha vida social (Jackson, 2003, p. 17-18).
} 
paisaxe desempeña un papel fundamental: «Visualiza o patrimonio no que se apoia a identidade: patrimonio natural ou humano, antigo ou actual; acompaña as prácticas cotiás ou excepcionais e, especialmente, as prácticas simbólicas, festivas ou rituais, tamén fundadoras de identidade; pon en escena a inscrición dunha sociedade no seu territorio», explica Anne Sgard ${ }^{2}$. Agora ben, segundo esta autora, "paisaxe e territorio teñen en común unha dimensión fundadora, o tempo: o territorio inscríbese na duración e a paisaxe fálalle á memoria e bota as súas raíces no tempo» (Sgard, 1997). "Nesta memoria [precisa Bernard Bourgeois], inscríbese a civilización nas súas prácticas máis materiais» (Bourgeois, 1982, p. 208). En efecto, na propia carne da paisaxe están impresos e perduran todos os estigmas do pasado (Dagognet, 1982, p. 40).

É o caso do castro galego ${ }^{3}$, elemento máis característico da paisaxe e pegada celta inscrita no territorio. $\mathrm{O}$ castro converteuse en obxecto de estudo da historia reivindicativa que nacía no século XIX en Galicia, explica a historiadora Beatriz Díaz Santana (2002, p. 53). Foi dotado non só dun valor histórico senón tamén ideolóxico. Os primeiros historiadores románticos analizaron as características diferenciais da paisaxe galega: "A estrutura atomizada da propiedade [precisa Beatriz Díaz Santana] foi vinculada coas comunidades celtas pre-romanas» (Díaz Santana, 2002, p. 133-134).

Ademais, a Arqueoloxía da paisaxe establece que o campesiñado, presente desde a Idade do Ferro, ten configurado un tipo específico de ocupación do espazo e, sobre todo, de paisaxe (Díaz Santana, 2002, p. 112-113). Para o historiador Manuel Murguía (1833-1923), o campesiñado sintetizaba a esencia dos antepasados celtas, xa que nel se mantiñan vivas as tradicións e a paisaxe. Esta opinión foi compartida por Vicente Risco (1884-1963), que define a identidade galega pola súa poboación de campesiños e de mariñeiros, e pola súa organización natural, que é a parroquia, comunidade esencialmente agraria e rural. «Os labregos eiquí son todo, non somentes por compoñel-a imensa maor parte da poboación, senon por seren os que nos manteñen a todos» (Risco, 2000, p.

\footnotetext{
2 «A paisaxe [conclúe Anne Sgard] está sentida como unha forma apropiada de transcrición da identidade territorial e constitúe un dos principais temas do discurso identitario en todo caso nas sociedades rurais»; (Sgard, 1997).

${ }^{3}$ Os castros son organizacións urbanas. Apareceron no século X a. de C. Tratábase de instalacións fortificadas situadas en outeiros estratéxicos para controlar o camiño do metal.
} 
21-22). Castelao (1886-1950), pola súa parte, define o ruralismo como forma de instalación natural dos galegos en oposición clara coa urbana: «a poboación está distribuída en natural desorde, coma nos países celtas, i en evidente contraste cos módulos de agrupamento social en Castela e demais rexións hespañolas» (Rodríguez Castelao, 2000, p. 169). Así mesmo, Manuel Murguía afirmaba que esta paisaxe dividida das comunidades campesiñas galegas era idéntica no pasado. $\mathrm{O}$ vínculo entre pasado e presente reflectíase nunha mesma paisaxe rural. Durante o século XIX, o campesiñado galego representou a identidade nacional nacida da cultura castrexa (Díaz Santana, 2002, p. 137). Así naceu a idea de que aquel asentamento castrexo estaba ao principio da ocupación do espazo galego e da distribución administrativa das súas parroquias, tan características da paisaxe (Díaz Santana, 2002, p. 124-126). Para o historiador Pereira Menaut, unha mesma paisaxe equivale a unha mesma identidade cultural, xa que, segundo este autor, a paisaxe é a consecuencia dun proceso histórico que o explica e lle dá unha identidade. Este feito diferencial, que existiría, segundo Pereira Menaut, desde a Protohistoria, marca e determina a identidade nacional galega (Díaz Santana, 2002, p. 130).

Esta terra galega, para Castelao, pérdese nas orixes dos tempos e confúndese así co solo orixinario sobre o que apareceron os primeiros homes: «Non esquezamos que Galiza era unha insua de rocas ígneas criadas polo lume astral, e que xurdía, outa e forte, dos mares formativos, en cuio caos aínda xacía o que hoxe chamamos Hespaña» (Castelao, 2000, p. 89). Desta terra, xorde unha enerxía incoercible xeradora de inmortalidade. É froito do encontro entre o home e a paisaxe e, en verbas do xeógrafo e escritor Ramón Otero Pedrayo (1888-1976), «nun entrar da paisaxe no home e do home na paisaxe, creouse a vida eterna de Galiza» (Castelao, 2000, p. 335).

$\mathrm{Na}$ encrucillada do tempo e da identidade, Galicia, a súa terra e as súas paisaxes son fieis ao "fondo primitivo» a partir do que se crearon, como se a paisaxe galega invitase a recobrar o estado inicial do mundo. A paisaxe, segundo Castelao, é o froito da natureza e dunha historia que se remonta, en Galicia, á Idade Prehistórica, cando as formas actuais de Castela -mesmo a paisaxe- naceron nas últimas etapas da Reconquista (Castelao, 2000, p. 347-349). «Maxinemos unha resurreición dos mortos de fai mil [di Castelao]: un galego recoñecería a súa terra; un castelán non sabería decir onde estaba» (Rodríguez Castelao, 2000, p. 351). 
Vemos aquí a vontade de insistir na inmutabilidade da paisaxe galega, unha paisaxe inscrita nunha civilización que ten as súas orixes nun encontro inmemorial entre o home e mais a Terra atravesada de universalidade: «dende a máis pequena fiestra pode contemplarse a inmensidade do ceo coma dende a máis pequena terra se pode comprender a grandeza do mundo» (Rodríguez Castelao, 2000, p. 324).

Esta terra, que compara a «unha inmensa esmeralda engarzada no extremo da cordilleira cantábrica» (Rodríguez Castelao, 2000, p. 543), diferénciase ou mesmo se opón ao resto de España pola súa beleza; así, dúas veces en Sempre en Galiza, Castelao declara: «Eu sei que tódolos galegos estamos orgullosos de ser fillos da Terra máis fremosa de Hespaña e cicais a máis fremosa do mundo» (Rodríguez Castelao, 2000, p. 306). Fronte a esta terra galega fecunda, rica en paisaxes verdosas, están as "chairas desertas, resecas e calvas da Meseta» (Rodríguez Castelao, 2000, p. 348). A poeta Rosalía de Castro (1837-1885), no prólogo dos seus Cantares gallegos, eleva as paisaxes de Galicia á categoría de ideais, de modelos culturais e estéticos. E, despois de estigmatizar os da Mancha ou de Estremadura, de Alacante e mais de Murcia, feitos de campos monótonos, describe as xoias da paisaxe galega, estes elementos do cotián que fan do seu país «un dos máis encantadores da terra». A hostilidade de Rosalía de Castro é tanto cara aos «castellanos» -manifestada por exemplo no poema «Castellanos de Castilla»- como contra unha paisaxe que non entende.

No medio do deserto castelán, as cidades, caos urbano e axitado, opóñense ao campo galego, único depositario das esencias eternas: un «inxénito ruralismo» fronte a unha "retrasada urbanidade», segundo Castelao. O discurso de Castelao ten así acentos «rousseauniáns». Trátase, segundo a análise de Ramón Maiz, da dimensión do ruralismo como paisaxe: o campo idealizado -como unha Arcadia- representa un antídoto contra a axitación da cidade. De aí o perigo dun poder castelán que imporía as súas decisións na paisaxe; no seu percorrido polo territorio galego, Castelao constata o que "para nós, siñificou e siñifica o Estado hespañol nascido en Castela» (Rodríguez Castelao, 2000, p. 347) e fala de montañas antes poboadas de árbores e logo totalmente «calvas» e de que sofren unha «maldita esterilidade» a causa das decisións de Castela, cando poderían ter constituído, pola contra, «a nosa fonte principal de riqueza». "Nestes montes [resume o teórico], está presente o ideal arrasador de Castela, nemiga 
dos albres e dos paxaros» (Castelao, 2000, p. 347). Este poder nefasto, esta man castelá diabólica veu a empobrecer e desecar a paisaxe galega: «Non é pois, necesario saír de Galiza para ver a Castela ou para comprender o mal que esta causou a Hespaña no proceso de unificación nacional», afirma Castelao (Castelao, 2000, p. 347). Así e todo, asegura con tranquilidade que: «O que non podía morrer era a Terra -siño permanente da nación- porque por moito poder que o Estado centralista tivese, sempre resultaría impotente para convertir o noso territorio en planura castelán» (Castelao, 2000, p. 91), exemplo, para Castelao, de fealdade e de infertilidade. Xa que logo, propón que, «se a unificación fose comenente, non sería máis cordo galeguizar a Castela que castelanizar a Galiza?» (Castelao, 2000, p. 91).

Pero alén do aspecto concreto da paisaxe, o cariño que teñen os homes por ela mostra unha vez máis o abismo que separa os galegos dos casteláns: este cariño e fascinación fai que se opoñan os galegos contemplativos, os que lle renden culto á natureza, aos casteláns, que prefiren unha relixión descarnada e baldeira de contidos terrestres. «Se quixeramos diferenciar o esprito galego do esprito castelán diríamos que están representados nas lendas de Don Ero e do padre Navarrete. Nós somos o monxe que ficou en éistasis polo canto dun paxaro; eles son o monxe que mandou calar aos paxaros para entregarse á meditación», resume Castelao (Castelao, 2000, p. 439). De aí o seu desexo: «Como lle queremos á Terra! Eu de min sei decirvos que se dispois de morto tivese que voar máis alá das estrelas visibles, para ir a un ceo tan lonxano da Terra, que nunca máis poidera vela, de boa gana renunciaría á inmortalidade para rematar a miña vida debaixo dunha laxe e convertirme en herbas ventureiras» (Castelao, 2000, p. 92).

Así e todo, cada galego ten unha forza que o empurra a deixar a súa terra. Pero, neste caso, tamén a diferenza cos seus veciños é grande: «Os casteláns sofren miseria i escravitude por non aleixárense da familia, dos colchóns, dos pucheiros, dos barreñóns, das tixolas e do gato [...]. Os casteláns non se moven do chan nativo o vanse del para sempre. Non hai dúbida de que a emigración galega revela unha diferencia de carácter cando se compara co sedentarismo castelán. Hai unha forza que nos empurra cara o mundo e outra que nos xungue á terra nativa, pois se os camiños nos tentan a camiñar é porque deixamos unha luz acesa sobor da casa en que fomos nados, e alí nos agarda ao fin da vida. 
Andar, andar, andar, e no remate dos traballos devolverlle á Terra o corpo que ela nos emprestou» (Castelao, 2000, p. 297-298).

Este regreso cara ao chan maternal está inscrito, segundo Castelao, en cada ser galego, como se home e terra fosen un: un mesmo espírito expresado na saudade -sufrimento por estar afastado- e un mesmo corpo arraigado para sempre no chan de Galicia.

Evocando o amor dos galegos pola natureza, Castelao explica que a base do ser galego é a terra. Para Vicente Risco, a terra é como Deus, un ser adorado e sagrado. Este «sentimento relixioso da terra», como o chama o propio Risco, reúne a todos os galegos e «distingue á alma galega» (Risco, 2000, p. 17); ofrece unha característica da súa personalidade e da súa identidade colectiva. Este sentimento é a base dunha ética e dunha estética (Risco, 1920). Está vinculado coas orixes de Galicia e a «sobrevivencia indudabel d'unha emoción ancestral [...], a emoción sagrada dos primeiros abós celtas [...] y-esta emoción talmente se plasmou nas sus almas primitivas, qu'estas gardaron xa para sempre aquil deslumamento y-aquil amore qu'eles nos trasmitiron no sangue coma un heredamento espirtual que vive na lembranza escura da Raza» (Risco, 1920).

Así, alén dun sistema de produción de bens materiais, a paisaxe é tamén fonte de bens culturais. Para Castelao, o ruralismo de Galicia orixinou unha cultura nobre, europea e humana, o episodio dos Cancioneiros, sendo un dos máis famosos. A poesía galega é, segundo Castelao, «unha poesía ao ar libre, con paisaxes de infinida fremosura» (Castelao, 2000, p. 341). Para Manuel Murguía, un poeta galego tiña que inspirarse na paisaxe, o vínculo coa natureza é a especificidade da literatura galega (Fortes, 2000, p. 73). E Rosalía de Castro confirmouno no prólogo do seu libro Follas novas, «o poeta non pode prescindir do medio no que vive e da natureza que o rodea» (Fernández, 1983, p. 321), vinculando así os creadores co seu contorno, como nunha relación umbilical entre o home e o medio natural. Como o poeta, o artista -pintor ou escultor- tamén se nutre da paisaxe e dunha atmosfera galega específica buscada no clima, a luz e os elementos naturais. Desde o Romanticismo, o mesmo amor pola paisaxe está presente nos artistas galegos, como asegura o pintor Raimundo Patiño Mancebo (1936-1985) (1978, p. 478). En Arte e galeguismo, escrito en 1919, Castelao define as bases dunha arte nacionalista que sexa, asemade, universal. Fai mención a unha identidade colectiva vinculada á terra, xa que, segundo 
pensa, toda arte ten a súa patria. Manuel Murguía foi o primeiro en se referir á existencia dunha pintura galega, citando a importancia da cor, desde a época romántica. En opinión de Luís Seoane (1910-1979), pintor e crítico, a cor, as matizacións vinculan os artistas galegos cos dos demais países europeos do Atlántico norte. Unha serie de coincidencias probaría a existencia dunha expresión pictórica moi particular, caracterizada por unha forma singular, por un humor e mais un lirismo que «humanizan os elementos da natureza». Segundo este crítico, a pintura galega segue a corrente dunha pintura europea que, ao longo da costa atlántica, expón «unha liña romántica, non clásica, empeñándose en entender o misterio do home e da natureza» ${ }^{4}$. «Estas formas [...] mostran nos artistas galegos, unha observación da natureza e una unión con ela», explica Luís Seoane (Braxe e Seoane, 1996, p. 18). Esta actitude estaba inspirada na teoría do filósofo francés Hypolite Taine, que afirmaba que unha obra de arte era, ante todo, o produto da «raza» e do clima. Esta teoría determinista e naturalista vía a orixinalidade e o carácter innovador na identidade xeográfica 5 . Estévez Ortega, crítico respectado dos anos 20 e 30, falaba mesmo de "galicianía», é dicir, dun medio propicio a unha unidade pictórica ${ }^{6}$. Esta poética específica así como a relación coa paisaxe marcarán, segundo Antón Castro (1992, p. 45 e 141), unha posible identidade artística galega e definirán o que se chamará «a estética do granito», que Luís Seoane une, polas súas formas redondeadas, á arte celta (Seoane, 1979, p. 11). Segundo Seoane, a situación xeográfica galega, fronte ao océano, e a analoxía co conxunto dos países bañados polo Atlántico contribuíron a darlle forma á «estética do granito». Castelao, en Arte e galeguismo,

${ }^{4}$ Para os Noucentistas, o Mediterráneo forxa tamén un carácter peculiar e produce un tipo de sensibilidade artística. Segundo Antoni Gaudí: «os artistas mediterráneos sempre serán superiores aos nórdicos porque se dedican á observación da natureza».

${ }^{5}$ Di Taine: «Dúas fozas principais determinan os pensamentos e os actos dos homes: unha, a natureza, a outra, a cultura. Considerade alternativamente esas dúas forzas nas obras de arte que as fai visibles. Cada escola representou un temperamento, o temperamento do seu clima e do seu país» (cf. Guasch, 1985, p. 44).

${ }^{6}$ De aí a denominación desde aquela época dunha «Escola de pintura galega», aínda que o conxunto dos pintores rexionalistas está lonxe de constituír un corpo homoxéneo. Así mesmo, na escultura, os artistas van na procura dunha renovación plástica pola recuperación das formas tradicionais e a toma de conciencia da súa identidade cultural e espiritual. Máis tarde, o grupo dos Renovadores son, segundo Luís Seoane, os primeiros aos que se pode definir como os precursores dunha arte galega, cualificada por Seoane de "pintura da terra». O manifesto «Máis alá», de 1922, asinado polo poeta Manuel Antonio e o pintor Álvaro Cebreiro, tratou de romper co tópico costumista dos creadores galegos así como coa Xeración Nós, á que consideraron vinculada ao século XIX e ao pasado. 
explica estas coincidencias pola relación particular que ten cada galego coa natureza que soubo transformar nunha obra de arte chamada "paisaxe». Xa que logo, en cada galego agáchase un artista. O home fixo a paisaxe e esta fixo ao home e, aínda máis, a paisaxe fixo ao artista. Para Castelao, a paisaxe é o espello da creación do home e, asemade, esta imaxe devolta ao home nutre a súa creatividade. Así, Castelao aconséllalles aos artistas que copien os elementos, as formas, as materias da natureza para crear o seu propio estilo: «Nada de copear ornamentos gregos nin arquivoltas oxivais, somente a natureza» (Castro, 1992, p. 141). A arte, resume Castelao, é filla da paisaxe e do carácter do artista. Así, a paisaxe sería como o fío condutor cara á arte. O segredo dun verdadeiro artista é saber mirar a natureza e, sobre todo, entender a paisaxe para poder pintala: «Cómpre que os pintores coñezan Galicia para pintala. Cómpre que os galegos teñan no peito o sentimento da paisaxe para seren artistas» (Castro, 1992, p. 147). E precisa que "para pintar Galicia ten que sentirse, non doutra maneira se comprende que algúns pintores de sona, chegados de fóra declarasen impintables as paisaxes galegas. Son impintables para eles, mais non para nós. Son impintables para quen non comprende máis que o vermello, o azul e o amarelo; mais son pintables para quen está afeito a distinguir mil matices diferentes do verde, dende o case amarelo ata o case azul» (Castro, 1992, p. 150). Para Castelao, as cores xa marcan a diferenza con outras comunidades de España e proban a existencia dunha paisaxe diferente e, xa que logo, dunha identidade particular. A alteridade na creación artística galega empeza quizais pola cor.

Segundo Castelao, a saudade é a fonte principal de creación artística e poética: «Quen podería abolir a morriña dos galegos que viven fóra dos eidos nativos? Porque ese sentimento diferencial é fecundo para crear xeitos propios do ser e, polo tanto, da cultura» (Rodríguez Castelao, 2000, p. 218). A inspiración de Rosalía de Castro é, para Kathleen Kulp-Hill, a saudade ou tristeza producida pola ausencia, no tempo e no espazo, de seres e lugares amados. Esta nostalxia é a clave que lle dá acceso ao descubrimento dunha beleza ata o de agora perdida no cotián, e que se prolonga no tempo baixo a forma desta tristeza lancinante e fecunda chamada saudade.

A saudade, como espírito da paisaxe e forza da terra, interroga ao home, ás veces tortúrao, pero só para lle brindar unha riqueza espiritual que lle permita traspasar os límites da súa condición humana. Para Roberto Nóvoa Santos, 
médico e escritor (1885-1933) citado por Castelao, a saudade é unha enerxía da terra, que se lles transmite aos homes por medio de elementos misteriosos e interrogadores da paisaxe. E, para Castelao, un máis alá soñado, transcendido en realidade na súa propia terra: «A saudade [...] endexamais pode condurcirnos á desesperanza, porque coa ilusión do "máis alá" fuximos do mundo real e chegamos aos mundos ensoñados; podemos crear países de fadas, paradisos de felicidade, até confundir a nosa Terra co Ceo» (Rodríguez Castelao, 2000, p. 440). Esta saudade emerxe así do encontro entre o home e a paisaxe. Está, como o confirma Roberto Nóvoa Santos, «na íntima comunión do home coa paisaxe e na tendencia do home e revertirse á mesma terra que modelou a súa carne e a súa alma [...]. A visión da paisaxe crepuscular é o mellor estímulo da saudade [...]. A vontade de retornarmos aos eidos nativos cando estamos lonxe deles, intensifícase e culmina no "instinto da morte" que é forma suprema de reversión á terra» (Rodríguez Castelao, 2000, p. 438-439).

A saudade xorde coa ausencia ou o arredamento. Agora ben, a distancia ou, aínda peor, o exilio son vividos como unha aflición. No caso do exilio, a identidade persoal de todo individuo sofre unha inestabilidade ontolóxica, debida ao transplante xeográfico. Castelao, forzado ao exilio por razóns políticas durante e despois da Guerra Civil, rememora así os lugares aos que sente pertencer, nos que a súa vida individual se inscribe e se funde. Descríbeos no nome do grupo cuxa conciencia o absorbe naquel momento e esta dimensión colectiva envolve por completo as dimensións individual e persoal de Castelao ${ }^{7}$. No barco que bordea as costas mediterráneas, Castelao vive a experiencia da alteridade ${ }^{8}$, ao confrontar a paisaxe que divisa coa que rememora: «a presencia das costas meridionaes de Hespaña non son como para seducir a un patriota galego, porque nelas descobrimos a fisionomía dun estado moruno moi distante da nosa Patria» (Rodríguez Castelao, 2000, p. 547). Este confrontarse cos elementos da paisaxe

\footnotetext{
${ }^{7}$ Forma parte das modalidades da construción da identidade individual e da captación da alteridade. Os contornos familiar, social e colectivo son as diferentes fases da formación da identidade de cada individuo. $\mathrm{O}$ encontro entre estas tres fases participa da construción identitaria. No caso de crise grave, a identidade colectiva envolve as demais (Mucchielli, 2002, p 72-73).

${ }^{8} \mathrm{~A}$ «captación da alteridade» é propicia para «a construción dunha conciencia de pertenza colectiva». A chegada a «terras alleas, consecutiva ao exilio, vívese, en certa medida, como unha agresión que provoca un repregamento no seo do grupo", de xeito que está dividido entre observación e rememoración (Delrue, 2006).
} 
fai que se recolla no seu interior e se refuxie na evocación das paisaxes da súa terra. Noutro capítulo de Sempre en Galiza, Castelao describe unha estadía en Estremadura: oponlles á secura, á impresión de afogo e de desidia, os elementos da paisaxe galega, a «sombra fresca das carballeiras de Lalín», os «piñeiraes da beiramar de Noia», os «arumes mariñeiros de Bueu», o «cume do Montelouro», a «frescura do meu mar de Rianxo», a «fonte cantareira da Estrada», os «salseiros de Corrubedo», o «ar puro de Curtis», ou a "paz vizosa do Lérez»; e só diante destas evocacións se sente "fortalecido" (Rodríguez Castelao, 2000, p. 69).

O territorio galego é magnificado polo sufrimento. «Quen podería abolir a morriña dos galegos que viven fóra dos eidos nativos?» (Rodríguez Castelao, 2000, p. 91), pregunta Castelao. O exilio -ou o que se vive como tal- reaviva o cariño e exacerba a fermosura; a memoria é atormentada por formas, cores, lugares, obxectos que compoñen paisaxes, que se converten en seres vivos cuxa ausencia funde ao home nunha profunda nostalxia. Castelao, durante o seu exilio, espertou unha madrugada nun hotel de Marsella e sorprendeuse lembrando un discurso de Otero Pedrayo que cita de memoria: «Se no abrente deste día poidéramos voar sobor da nosa Terra e percorrela en todas direccións, asistiríamos á marabilla dunha mañán única. Dende as planuras de Lugo inzadas de bidueiros, até as rías de Pontevedra, oureladas de piñeiraes; dende as serras nutricias do Miño e a gorxa montañosa do Sil, até a ponte de Ourense, onde se peitean as augas de entrambos ríos; ou dende os cabos da costa brava da Cruña, onde o mar tece encaixes de Camariñas, até o curuto do monte de Santa Tegra, que vence coa súa sombra os montes de Portugal, por todas partes xurde unha alborada de groria» (Rodríguez Castelao, 2000, p. 520).

En Castelao, a paisaxe galega e o paraíso terrestre son un. Varias veces cualifica a paisaxe de Galicia de "paradiso», xa que os galegos «superaremos a predición relixiosa e trocarémola en Paradiso» (Rodríguez Castelao, 2000, p. 92). A paisaxe suscita en moitos autores esta comparación co paraíso, é, resume Raffaele Milani, «a memoria e a esperanza dunha alegría intemporal» (Milani, 2005, p. 140). En Castelao, os elementos da paisaxe anímanse e convocan cadanseu anaco de beleza e de ideal ao servizo do único territorio galego: «A arquitectura barroca do noso chan, labrada en pedra granítica, está sempre coberta por un manto de xugoso verdor. Os montes son redondos como peitos de muller e as serras son como lombos de boi cebado. Os vales son ledos e farturentos. O mar 
tolea de carraxe cando non o deixan penetrar na terra; pero cando entra, quédase adormecido no leito das rías» (Rodríguez Castelao, 2000, p. 90). Cada elemento simboliza a paisaxe e, para Castelao, a patria é a conxugación dos elementos típicos da paisaxe galega: «o carballo, o mar, o trigo, a noite estrelada ou a chuvia..." ${ }^{9}$, elementos que animan a paisaxe e "difunden a identidade», se empregamos a expresión de Anne Sgard.

O proceso identitario está a funcionar: a identidade engánchase a elementos pouco espectaculares, pero moi ben identificados e repetidos. Estes mesmos elementos opóñense ao que se pode atopar a outro lado da "fronteira». Xa que, como explica Raffaele Milani, a paisaxe precisa certa percepción dos límites e ten que estar circunscrita por un horizonte momentáneo ou duradeiro (Milani, 2005, p. 39-40). Agora ben, «unha paisaxe identitaria resúmese facilmente a través dun ou varios compoñentes ben recoñecibles aos que a paisaxe pode amarrarse; unha paisaxe uniforme, fuxitiva, na que non se desprende ningún elemento, dificilmente atopa un valor identitario», precisa Anne Sgard (1997). Castela, cunha paisaxe máis austera, confúndese nos escritos políticos ou poéticos co «deserto», palabra usada por Rosalía de Castro e tamén polo escritor, xornalista e político Antón Vilar Ponte (1881-1936) nunhas cartas enviadas ao poeta Teixeira de Pascoaes (1877-1952), para o que a paisaxe constituía unha inextinguible fonte de inspiración (Vilar Ponte, 1999, p. 59 e 131). Así, o deserto castelán e o fértil territorio de Galicia están separados por unha «fronteira». Trátase aquí dunha fronteira identitaria, o que significa, lembra Jackson, «o que se mantén xunto. $\mathrm{O}$ acento ponse tanto sobre o que separa como sobre o que vincula" (Jackson, 2003, 14-15). Agora ben, este país único é como unha pedra preciosa, protexido por «fronteiras naturais», que rodean unha unidade paisaxística ben identificada: para Castelao, só a rexión do Miño, cruzada por unha fronteira oficial, pero artificial, comparte unha mesma paisaxe, froito dunha única civilización: «Cando un galego entra nas planuras de León ou de Zamora, síntese en terra allea, invadido pola tristura que producen os desertos. Cando entra en Asturias ten que afacer os seus ollos a un novo estilo de paisaxe. Pero cando traspón a fronteira portuguesa, síntese na propia terra, e non dá creto ás arbitrariedades da política hestórica» (Castelao, 2000, p. 90).

\footnotetext{
${ }^{9}$ Véxase Rodríguez Castelao, «Homenaje al Consello de Galicia», Montevideo, 01/07/1945.
} 
Antón Vilar Ponte explica nun artigo da revista Nós que a influencia da paisaxe propiciou a creación de vínculos de amor entre Portugal e Galicia, separados por unha fronteira «absurda» (Vilar Ponte, 1921). O poeta Xavier Bóveda Pérez (1898-1963) fala dunha «alma galaico-lusitana», que comparte un mesmo «saudosismo» (Vilar Ponte, 1999, p. 51).

Castelao resume así a unicidade do territorio galego: «Galiza é unha unidade territorial harmónica, de formas e coor, perfeitamente diferenciada do resto da Hespaña» (Rodríguez Castelao, 2000, p. 90), un territorio español que el rexeita.

Así, cada elemento da paisaxe serve tanto para definir como para opoñerse. Ademais, cada un é non só marcador dunha identidade colectiva, senón tamén dunha identidade individual; Rosalía foi unha dos primeiros autores que sentiu a paisaxe como elemento central non só da identidade galega senón mesmo da súa propia identidade persoal. Segundo Michel Collot, «a procura ou a elección de paisaxes privilexiadas é unha forma buscarse a un mesmo» (Collot, 1995, p. 217-218). «O corpo da nai [explica este autor] define o primeiro espazo confiado á exploración da persoa [...]. Jean Guillaumin formulou a hipótese de que a paisaxe adulta conservaba esta marca maternal [...]. Esta hipótese está confirmada pola abundancia das metáforas de uso que, na descrición das paisaxes, remite á nai». O propio Vicente Risco, nun discurso panteísta ve a terra como unha «segunda placenta», xa que o noso corpo «é un anaco d'éla [...]: éla está en nós [...]. Éla está na nósa y-alma e no nóso entendimiento, que d’éla veñen, que d'éla son fillos, como o corpo o é. Éla enche d'imaxes o nóso interior, y-esí como alimenta ó corpo co-as especies físecas, tamén alimenta á y-alma co-as especies sensibles. Pertenecémoslle en corpo y-alma» (Risco, 1920). Raffaele Milani aborda o tema da protección materna baixo a «forma dunha totalidade envolvente e difusa, como unha flutuación ininterrompida de emocións e de datos perceptibles, unha irradiación afectiva» (Milani, 2005, p. 51). Para Michel Collot, o xardín é, sen dúbida ningunha, a metáfora do ventre materno. A poeta Rosalía de Castro, no prólogo de Cantares gallegos, fala de Galicia como dun "xardín no que se respiran aromas puros, frescura e poesía». Un lugar que se converte en verdadeiro xardín do Edén en Castelao: «Vexo [...] unha Terra farturenta, onde todos traballan e viven en paz. Vexo a miña Terra como unha soia cibdade, a cibdade-xardín máis fermosa do mundo, a cibdade ideal para os homes que queiran vivir a carón da Natureza» (Rodríguez Castelao, 2000, p. 
189). Agora ben, o xardín, explica Michel Collot, é «o lugar pechado e secreto cos seus misterios no que estamos» (Collot, 1995, p. 277). Ten ese lado interior, íntimo, lugar ideal da construción da súa propia identidade persoal. Antón Vilar Ponte, citando ao poeta portugués Teixeira de Pascoaes, expón nun artigo da revista Nós o papel central da paisaxe na existencia do home, xa que a alma da paisaxe lle transmite as súas calidades á alma humana. Así, unha paisaxe pode influír positiva ou negativamente. Cita dous exemplos: a Rexión do Miño, que presenta unha paisaxe alegre, e a de Trás-os-Montes, que, cunha paisaxe dolorosa, rexistra máis crimes (Vilar Ponte, 1921). Tamén o confirma o poeta e dramaturgo Xavier Bóveda Pérez nunha carta mandada ao seu colega portugués: segundo Bóveda, a alma galega é un "produto» da paisaxe (Vilar Ponte, 1999, p. 51). Así, a paisaxe galega marca aos homes ata revelalos e revelar neles formas e caracteres do seu ser que non sospeitaban. A paisaxe é un elemento que esculpe ao individuo galego.

A paisaxe identitaria desempeña, así, dúas funcións: unha, de cohesión interna, que é a que nos interesa, e outra función externa de produción dunha imaxe destinada á mirada exterior, explica Anne Sgard. Pero precisa, «o discurso sobre a paisaxe é un discurso eminentemente cultural. Manexa o vocabulario estético, presenta unha mirada distanciada e comparativa, expresa esa percepción de maneira analítica, argumentada» (Sgard, 1997). É un discurso cultural, pero tamén ideolóxico e político, mesmo nos poemas de Rosalía de Castro. «O lado político cobre o posto máis ancho e agresivo», explica Ricardo Navas Ruiz, no seu comentario do poema "Castellanos de Castilla»; céntrase en dúas cuestións: a dureza de corazón dos casteláns e a fealdade da paisaxe de Castela, en comparación coa galega. E Ricardo Navas Ruiz pregunta, sen contestar, se se pode falar de conciencia separatista, xa que a representación da paisaxe, expresión dun ideal de beleza e de organización, revela ser o vehículo privilexiado dun ideal político, que se manifestaría no recoñecemento dunha Nación galega. Segundo Castelao, a patria atopa as súas orixes e o seu carácter na terra: a terra nai alberga «unha moitedume infinida de luciñas, que son os seres innominados que ninguén recorda xa, e que xuntos forman o substractum insobornable da nosa patria» (Rodríguez Castelao, 2000, p. 519). Vicente Risco, evocando o amor innato dos galegos pola terra, chega a falar de "patriotismo vexetal» (Risco, 1920). 
Agora ben, para Castelao, «a Patria é a Terra», pero, cando describe esta Terra, convértea en álbum de paisaxes: «A Terra, que cría frores nos campos para regalía dos ollos e albres para que canten os paxaros; onde atopamos sombra fresca no vran e quentura garimosa no inverno[...]; onde o vendaval brúa nas ponlas dos carballos e funga nas cordas dos barcos; onde canta o vento nos piñeiras[...]; onde por primeira vez ollamos a choiva, a brétema, o sol, o luar, o arco da vella e a noite estrelecida» (Castelao, 2000, p. 92).

En Vicente Risco, a Terra, máis que as paisaxes, é signo da existencia dunha única e soa etnia. En efecto, para Risco, o factor terra é a condición da nacionalidade ${ }^{10}$, que separa «as nacionalidades nómadas das nacionalidades sedentarias [...]. Falamos eiquí de pobos sedentarios, de pobos civilizados, de pobos europeos. Ora, en Europa, unha nacionalidade é un pobo afincado n-unha terra» (Risco, 2000, p. 17). E a nación, para Vicente Risco, é «unha comunidade d'intreses espirtuaes e materiaes detreminada pol-a natureza» (Risco, 2000, p. 18).

A Terra implica a pertenza e o enraizamento. A etnia é o froito da Terra; a paisaxe, pola súa banda, depende do home. É obxecto e suxeito, obxectivo e subxectivo. Lugar da infancia e do íntimo, é o crisol en que se funda a identidade persoal, xa que é o lugar do cotián, obxecto dun vaivén constante entre o home e mais a natureza. Pegada histórica, marca social e patrimonio cultural, a paisaxe é tamén unha das representacións da identidade colectiva, xa que é, coma ela, plural, complexa, aberta ás influencias e evolucións. A paisaxe é, na teoría nacionalista galega, a condición sine qua non que constrúe o home, o pobo e o artista. A Terra, pola súa parte, é, nos discursos nacionalistas, unicamente étnica. De aí o nacemento das teorías racistas vinculadas á etnicidade suposta dos homes que comparten unha mesma Terra. En Vicente Risco, a paisaxe é un dato, unha doazón da natureza. Como conclusión do seu ensaio Teoría do nacionalismo galego propón dúas medidas para protexela; a primeira é a construción de «miradores pr'os turistas nos vales mais pintorescos da nosa Terra, coma ningunha rica en paisaxes fermosos» (Risco, 2000, p. 43); a segunda forma parte dunha demanda máis global: a de "proclamar a soberanía estética da Nazón Galega» e

${ }^{10}$ Do mesmo xeito, o teórico nacionalista catalán Enric Prat de la Riba situaba a terra como o primeiro dos elementos que constitúe a nacionalidade (Prat de la Riba, 1988, p. 89). 
que se exercerá netamente na "espropiación de moimentos e paisaxes» (Risco, 2000, p. 39). Desafortunadamente, Risco non dá máis detalles sobre estes proxectos de nacionalización dos lugares estimados como os máis fermosos do territorio. Estas propostas levan o selo dunha paisaxe intocable e sagrada, cando en Castelao é o resultado dun intercambio constante e sempre respectuoso entre o home e a natureza. A paisaxe é cultural en Castelao, e étnica en Risco. Este matiz de aproximación marca, sen dúbida ningunha, unha diferenza ideolóxica entre os dous. En Castelao, a teoría da paisaxe está fundada esencialmente no seu carácter «insulario», é dicir, na súa impermeabilidade con respecto a un contorno hostil e ameazante; convértese así na expresión sublimada dun ideal estético e dunha vontade política. 


\section{BIBLIOGRAFÍA}

BERTRAND, G.: «Le paysage entre la Nature et la Société», en A. Roger (dir.): La théorie du paysage en France (1974-1994), Seyssel, Ed. Champ Vallon, 1995.

Bourgeors, B.: «L'idéalisme allemand devant la beauté naturelle et l'embellissement de la nature», en F. Dagognet (dir.): Mort du paysage? Philosophie et esthétique du paysage, Seyssel, Ed. Champ Vallon, 1982, pp. 161-181.

BraXe, L. e X. Seoane: Luís Seoane. Textos sobre arte, Santiago de Compostela, Consello da Cultura Galega, 1996.

Castro, A.: Arte y nacionalismo. La vanguardia histórica gallega (1925-1936), Sada (A Coruña), 1992.

COLlignON, B.: «Les fondements territoriaux de l'identité inuit hier et aujourd'hui», en J. BONNEMAISON, L. Cambrezy e L. Quinty-Bourgeois: Les territoire de lidentité. Le territoire, lien ou frontière?, t. I, Paris, L'Harmattan, 1999.

Collot, M.: «Points de vue sur la perception des paysages», en A. ROGER (dir.): La théorie du paysage en France (1974-1994), Seyssel, Ed. Champ Vallon, 1995.

Dagognet, F. (dir.), Mort du paysage? Philosophie et esthétique du paysage, Seyssel, Ed. Champ Vallon, 1982.

DelRUe, E.: «Repercuciones de exilio/desexilios en la conciencia colectiva y/o individual: algunos libros de viaje de Vicente Blasco Ibañez», en Exilio y desexilio en el mundo hispánico contemporáneo. Los caminos de la identidad. Actas del Congreso, Universidad de Gijón, Hispanística, 2006.

Díaz Santana, B.: Os celtas en Galicia, A Coruña, Editorial Toxosoutos, 2002.

FERnÁndez, X. R.: Historia contemporánea de Galicia, A Coruña, Gamma, 1983.

ForTes, B.: Manuel Murguía e a cultura galega, Santiago de Compostela, Ed. Sotelo Blanco, 2000.

Guasch, A. M.: Arte e ideología en el País Vasco: 1940-1980, Madrid, Akal, 1985.

JACKSON, J. B.: A la découverte du paysage vernaculaire, 2003. [Biblioteca Nueva prepara unha edición en castelán].

MilANI, R.: Esthétique du paysage, 2005. [Hai edición en castelán: El arte del paisaje, Madrid, Biblioteca Nueva, 2007].

Mucchielli, A.: Lidentité, Paris, PUF, 2002.

PatiÑo MANCebo, R.: «La expresión artística», en Galicia, realidad económica y conflicto social, A Coruña, Banco de Bilbao, 1978.

PRAT DE LA RibA, E.: La nacionalidad catalana, Madrid, Biblioteca Nueva, 1988.

RisCO, V.: «O sentimento da terra na raza galega», Nós, n. ${ }^{\circ}$ 1, Ourense, 30 outono, 1920.

Risco, V.: Teoría do nacionalismo galego, Santiago de Compostela, Sotelo Blanco, 2000.

Rodríguez Castelao, A. D.: Sempre en Galiza, Vigo, Editorial Galaxia, 2000.

SEOANE, L.: Textos encol da arte galega, Madrid, Brais Pinto, 1979.

SGARD, A.: «Paysages du Vercors: entre mémoire et identité», Revue de Géographie Alpine, Université Joseph Fourier, novembro, 1997.

Vilar Ponte, A.: «Da paisaxe e a pintura», Nós, n. ${ }^{\circ} 4,1921$.

Vilar Ponte, A.: Os intelectuais galegos e Teixeira de Pascoaes. Epistolário, Ediciós do Castro, 1999. 

Relatorio

PAISAXE E SENTIDO DE LUGAR Joan Nogué

Universitat de Girona

Observatori del Paisatge de Catalunya 

Vou reflexionar nestas páxinas verbo das relacións entre a paisaxe e o sentido de lugar. A cuestión é apaixonante e enormemente relevante, pero escorregadiza e facilmente manipulable desde un punto de vista ideolóxico e mesmo político. Velaí un terreo pantanoso, con areas movedizas a destra e sinistra. Nunca sabes de certo onde pos o pé. Segundo trates a cuestión, serás acusado de esencialista e romántico, no sentido histórico e literal da palabra, ou ben de moderno e cosmopolita, sempre en sentido despectivo, obviamente. A cuestión é clave, ademais, porque está na esencia mesma do debate nacionalista, onte e hoxe, neste país e en calquera recuncho do planeta. Despois de darlle moitas voltas, optei por enfocar a cuestión desenvolvendo e encadeando os seguintes puntos. Empezarei, en primeiro lugar, por facer unha reflexión sobre a paisaxe e a identidade territorial, é dicir, sobre o papel da paisaxe na formación e consolidación de identidades territoriais e sobre como a tradición académica se ten interesado desde sempre polo tema. A continuación, analizarei a conflitividade territorial contemporánea como reflexo da perda desta identidade e, asemade, do sentido de lugar. Finalmente, mostrarei algunhas propostas de protección, ordenación e xestión da paisaxe que aspiran a preservar o sentido de lugar e a identidade territorial, e a reducir, xa que logo, esta conflitividade territorial.

\section{PAISAXE E IDENTIDADE TERRITORIAL}

Gustaría empezar recordando algo obvio sobre o que ás veces convén volver: en xeral, a xente séntese parte dunha paisaxe, coa que establece múltiples e profundas complicidades. Este sentimento é lexítimo, ancestral e universal e aínda que é verdade que a tensión dialéctica entre o local e o global, xerada polo que habitualmente entendemos por globalización, está a afectarlles moitísimo aos lugares, tamén o é que, en boa medida, seguimos a actuar como unha cultura territorializada, aínda que ás veces non o pareza. 
Cando falamos de paisaxe, estamos a referirnos, no fondo, á paisaxe cultural, é dicir, a unha porción da superficie terrestre que foi modelada, percibida e interiorizada ao longo de décadas ou de séculos polas sociedades que viven nese contorno, o que nos leva, inevitablemente, a vincular paisaxe e identidade territorial. A paisaxe está chea de lugares que encarnan a experiencia e as aspiracións da xente; lugares que se converten en centros de significado, en símbolos que expresan pensamentos, ideas e emocións varias. A paisaxe non só nos presenta o mundo tal e como é, senón que é tamén, dalgún xeito, unha construción deste mundo, unha forma de velo. De aí o relevante papel que sempre xogou a paisaxe na formación e consolidación de identidades territoriais, a todas as escalas, entre elas a identidade territorial nacional. As identidades territoriais téñense conducido historicamente e en boa medida a través da paisaxe.

É indubidable que os lugares -e as súas paisaxes- teñen acusado o impacto das telecomunicacións, da maior velocidade dos sistemas de transporte, da globalización dos mercados, da estandarización das modas, dos produtos, dos hábitos de consumo. Non en van falamos de homoxeneización e de banalización da paisaxe. É certo que apareceron «non lugares», que emerxeron territorios sen discurso e que creamos paisaxes sen imaxinario, pero, con todo, penso que moitos lugares conservan aínda o seu carácter e que nos resistimos a perder o sentido de lugar: non nos resignamos a que se elimine de golpe a identidade das nosas paisaxes, e a conflitividade territorial hoxe existente é unha proba diso, como veremos máis adiante.

Existe unha prolongada e rica tradición de reflexión académica e intelectual no tocante ao tema da identidade territorial e a súa vinculación coa paisaxe. Non se trata aquí de entrar a fondo nela, pero non podo deixar de citar algúns fitos neste terreo, limitados ao ámbito disciplinar do que proveño -a Xeografía humana-, pero que son xeneralizables ao conxunto das Ciencias sociais e humanas. Cómpre recoñecer, de entrada, que as máis importantes escolas xeográficas europeas de fins do século XIX e de boa parte do XX lle concederon unha grande importancia ao asunto. Na alemá Landschaftgeographie dábase unha clara asociación de ideas entre paisaxe e rexión, dous conceptos utilizados practicamente como sinónimos. O mesmo podemos dicir da rica tradición xeográfica francesa da época, a denominada escola rexional francesa ou escola vidaliana, na honra do seu fundador Paul Vidal de la Blache, tan influente en España. Para 
eles, a paisaxe era a fisionomía característica que nos revela unha porción do espazo concreta - unha rexión- e que a distingue doutras. Na rexión -no lugar, se así se prefire- cristalizan as relacións entre natureza e cultura, segundo esta tradición. A conexión entre cultura e natureza daríalle á rexión un carácter distintivo que a faría única, irrepetible e que se visualizaría e se materializaría a través da paisaxe. A idea -que aínda hoxe repetimos- de que a paisaxe é, dalgún xeito, o rostro do territorio está consolidada neste momento. A tradición vidaliana non concibirá a Xeografía sen a observación directa sobre o terreo, sen o traballo de campo e -aínda máis que todo iso- sen impregnarse do genius loci das rexións estudadas. Hai aí unha conexión directa coa mirada xeográfica inaugurada por Humboldt ao concibir a rexión como o resultado dunha singular e única combinación peculiar de elementos naturais e culturais, que se materializaría nunha paisaxe determinada.

A paisaxe, na tradición xeográfica francesa, é, sen dúbida, un concepto fundamental e o seu estudo precisará dunha sólida formación científica, e mesmo tamén dunha gran base humanista. Xeógrafos como Jean Brunhes, Albert Demangeon, Max Sorre, Roger Dion, Camille Vallaux ou, no noso país, Manuel de Terán ou Pau Vila, entre moitos outros, son, sobre todo, homes moi cultos e que teñen unha especial sensibilidade, ademais de ser sólidos científicos. Escribían -e describían- dun xeito maxistral, cun esprit de finesse ao alcance de moi poucos homes de ciencia. Entendían que a esencia dunha paisaxe, o seu carácter e personalidade, non podía ser transmitida sen un dominio absoluto da linguaxe, o que converteu algunhas das súas obras en auténticos clásicos, en verdadeiras obras de arte. Neste sentido, Anne Buttimer (1980) chega a cualificar o Tableau de la géographie de la France, de Paul Vidal de la Blache, como a Mona Lisa da Xeografía moderna. Vidal, por certo, tardou moitos anos en completar esta obra simplemente porque se empeñou en visitar todas as rexións francesas antes de escribir sobre elas. Vidal aspiraba a descubrir o carácter das rexións francesas, a súa identidade territorial, en definitiva.

E, se cruzamos o Atlántico e nos situamos en América do Norte, atoparemos unha perspectiva semellante á francesa da man de Carl O. Sauer, xeógrafo que nos anos 1920 acuñou o concepto de paisaxe cultural, aínda hoxe vixente en moitos sentidos. A rica tradición norteamericana de estudos da paisaxe en tanto que expresión dun sentido de lugar débelle moito á obra dos xeógrafos culturais 
discípulos de Sauer. Figuras do calibre dun John Brinckerhoff Jackson, fundador da revista Landscape, non se entenden sen o legado de Sauer. E todos eles, sen excepción, vincularon a paisaxe e o sentido de lugar.

Pola súa parte, a Xeografía humana contemporánea segue empeñada en coñecer como se relacionan os seres humanos co seu contorno, como crean lugares e imbúen de significado o espazo xeográfico e como se xera o sentido de lugar. En concreto, a Xeografía humanística, de inspiración fundamentalmente fenomenolóxica, entende os lugares non como simples localizacións nin amorfos nodos ou puntos estruturadores dun espazo xeográfico que con demasiada frecuencia se concibe, asemade, como un espazo case xeométrico, topolóxico. O espazo xeográfico será concibido por esta escola como un espazo existencial e nel os lugares serán entendidos como porcións deste, imbuídas de significados, de emocións, de sentimentos. A súa materialidade tanxible está tinguida, bañada de elementos inmateriais e intanxibles que converten cada lugar nun algo único e intransferible, o que dá como resultado un particular genius loci, esprit du lieu ou, se se quere, sentido do lugar. Para conseguir o que agora se propón será imprescindible desenvolver unha metodoloxía de tipo cualitativo que permita descubrir esas relacións de carácter afectivo, sensorial e emotivo que establecemos cos lugares que nos rodean. Unha das figuras clave foi -e segue a ser- o xeógrafo norteamericano de orixe chinés Yi-Fu Tuan, autor de obras excepcionais como Topophilia: A Study of Environmental Perception, Attitudes, and Values (1974) ou Space and Place: The Perspective of Experience (1977), entre moitos outros.

Así pois, as interpretacións que adoitan vincular paisaxe e identidade territorial só en termos nacionalistas son parciais e limitadas, porque esquecen este outro tipo de identificacións territoriais coa paisaxe, estudadas a fondo por esta rica tradición académica e intelectual da que aquí só esbocei unha pincelada. A vinculación entre paisaxe e identidade nacional (García, 2002) é importantísima e eu mesmo téńoa estudado a fondo (Nogué, 1998; e Nogué, 2005), pero non é a única. Convén, non obstante, dada a súa relevancia, que recordemos o motivo polo que o nacionalismo considerou con frecuencia a paisaxe como un dos elementos fundamentais que articulan a identidade nacional.

A paisaxe que configura o territorio nacional, en tanto que plasma unha cultura no territorio a través de elementos tanxibles e intanxibles, será interiorizada e resaltada polo discurso nacional. O territorio nacional convértese desde esta 
perspectiva en algo máis que unha simple área xeográfica máis ou menos delimitada. Constitúe un territorio "histórico», único, distintivo, cunha identidade - materializada na súa paisaxe- ligada á memoria e unha memoria encadeada á terra (Nora, 1984-1992). A historia nacionaliza unha paisaxe e imbúe de contido mítico e de sentimentos sagrados os seus elementos xeográficos máis característicos (Branch, 1999). O territorio e as súas paisaxes convértense así no receptáculo dunha conciencia compartida colectivamente. É a terra nai, a homeland en lingua inglesa e a heimat en alemán. En 1887, Ferdinand Tönnies, un dos pensadores do século XIX que máis influíron na formulación dun nacionalismo entendido como forza inmanente e de raíces atávicas, utiliza repetidamente o concepto de heimat para fundar e darlles cohesión aos seus argumentos: «A comunidade de sangue únese á comunidade da terra natal (heimat), que inflúe de maneira singular sobre o espírito e o corazón dos homes» (Tönnies, 1984, p. 250-251). A zona colonizada e ocupada é daquela herdanza común, a terra dos antepasados, con respecto á que todos se senten e obran como descendentes e irmáns carnais. Neste sentido, pode considerarse sustancia viva que, cos seus valores espirituais e psicolóxicos, persiste no fluxo sempiterno dos seus elementos, é dicir, os seres humanos... A terra, como encarnación das lembranzas máis caras, sostén o corazón do home, que sae dela entristecido e, desde outras terras, mira cara a atrás con saudade e anhelo. Como lugar onde viviron e morreron os antepasados, onde os espíritos permanecerán e rexerán o ánimo dos vivos, a terra adquire para as almas e os corazóns piadosos e sinxelos unha significación valiosa e sublime (Tönnies, 1984, p. 251) na aldea e na cidade, o que crea as relacións e os lazos de unión máis estreitos é o solo físico e real, a localización permanente, a terra visible (Tönnies, 1984, p. 283).

No caso dun territorio nacional cunha gran diversidade paisaxística, adoitamos asistir a un proceso de «selección» dunha paisaxe que se converterá en arquetípica e representativa do conxunto. A «socialización» da paisaxe finalmente escollida produciríase nun momento dado da historia por parte dunha elite literaria e artística procedente dun determinado grupo social, que elaboraría unha metáfora e a difundiría entre o conxunto da sociedade. Evidentemente, está por ver se a imaxe seleccionada era a maioritaria e as que se deixaron a un lado, porque hai que admitir que todas elas, en tanto que representacións sociais da paisaxe, tiñan a mesma lexitimidade social. 
No proceso de conformación dunha paisaxe nacional asistimos a unha extrapolación de sentimentos desde unha micropaisaxe coñecida por experiencia directa a unha macropaisaxe -a totalidade do territorio nacional- que non se coñece por experiencia directa, senón a través doutras vías. De novo, a Xeografía europea desempeñou sempre un papel relevante neste eido. O desenvolvemento teórico e práctico da noción de pays por parte de Vidal de la Blache e os seus seguidores deulles argumentos a aqueles que non atopaban contradición ningunha entre rexionalismo e patriotismo, senón todo o contrario, posto que "sans petite patrie, il ne saurait y avoir de grande patrie», en palabras de André Mellerio reproducidas nun interesante artigo publicado en 1907 en L'Action Régionaliste baixo o significativo título de «La protection des paysages et le régionalisme» (Luginbühl, 1989). É a través da idea de paisaxe como factor de individualización dos pays franceses como se plasma, nos círculos partidarios dunha decidida intervención do Estado no tema da protección das paisaxes, a noción de petite patrie, á que algúns denominan, simplemente, matrie. Algo parecido aconteceu -acontece- en Cataluña entre a comarca, como pequena patria e nivel de identificación territorial a escala local, e o conxunto da patria, Cataluña.

Non todas as paisaxes actúan como lugares de identificación colectiva coa mesma intensidade. Non todas as paisaxes transmiten de idéntica maneira e coa mesma eficacia o sentimento de identificación como "pobo», como comunidade. Existen paisaxes cun valor simbólico nacionalista máis marcado que outras: no caso catalán, que analicei no seu momento, a montaña é, sen dúbida, a paisaxe estrela neste sentido. Efectivamente, a montaña converterase nun elemento fundamental na construción ideolóxica do catalanismo, algo que xa se estaba a xestar desde as décadas de 1830 e 1840 , que foi cando se iniciou a denominada Renaixença, un movemento literario de exaltación da propia lingua e das raíces culturais. Por aqueles tempos, Cataluña participaba xa das correntes de cambio na valoración estética e simbólica da montaña que se vivían no resto de Europa e este elemento da paisaxe converteríase co paso dos anos nunha peza clave da simboloxía catalá, nunha "paisaxe esencial» que lle daba sentido a todo o territorio. A partir dese momento, a montaña terá, cada vez máis, un carácter mítico, rexenerativo e case iniciático. Será símbolo de pureza e de virxindade. As orixes da nación buscaranse na montaña, nos Pireneos, e será tamén unha montaña -Montserrat- a que se converterá no símbolo por excelencia da patria catalá. As 
alusións a Montserrat, ao Canigó, aos Pireneos e ao Montseny, realizadas polos grandes poetas e escritores cataláns da época, son ben coñecidas. A montaña representa para estes escritores un espazo virxe, puro, sagrado, intacto; un reduto dos valores morais que alimentan o carácter e a identidade do pobo catalán.

A todo iso contribuíu, de xeito destacado, o excursionismo, que aparece no preciso momento en que se consolida o catalanismo político. Estreitamente ligadas aos primeiros pasos da Xeografía catalá moderna (Martí, 1994), estiveron «a indagación sobre as orixes, a investigación da personalidade e a necesidade de establecer un inventario xeral do país» (Casassas, 1979, p. 10), o que conduciu a un determinado sector da sociedade catalá finisecular cara ao excursionismo. Non se trataba dunha actividade deportiva calquera. A motivación dos seus practicantes era, fundamentalmente, de carácter patriótico e cultural, como testemuña o nome orixinario do Centro Excursionista de Cataluña (Associació Catalanista d'Excursions Científiques), fundado en 1876. En 1904, Joan Maragall, socio do centro, poeta nacional por excelencia e, por certo, avó de Pasqual Maragall, resume perfectamente este espírito do excursionismo catalán nunhas poucas frases que paga a pena reproducir:

Porque o noso excursionismo non é un deporte, non é un recreo, non é un estudo, que é un amor; e non é tampouco un amor abstracto pola natureza, senón pola nosa natureza [...]; e mal pode querer un home a toda a terra se non comeza por aquela da que forma parte; no amor á patria está contido o amor vivo a todo o mundo, e o que no nome deste renega daquel é que non ten nin un nin o outro [...]. Porque o noso amor á natureza vive no amor á natureza catalá; Cataluña é para nós compendio do mundo, e o noso amor universal é nela onde máis eficazmente se exercita. Por iso podemos dicir, coa cabeza ben erguida, que a alma do noso excursionismo é o amor a Cataluña, e niso si que todos somos un (Maragall, 1960, p. 860).

Despois do visto, é difícil cuestionar a enorme importancia do discurso nacionalista á hora de xerar sentimentos de identificación territorial, pero -insistoestes non son os únicos, nin os máis relevantes para explicar a conflitividade territorial contemporánea, que eu vinculo, precisamente, coa perda do sentido de lugar, como resultado da perda doutro tipo de identidade territorial. De todo isto falarei a continuación, pasando xa ao segundo punto que quería explorar. 


\section{DEGRADACIÓN DA PAISAXE E CONFLITIVIDADE TERRITORIAL}

A miña hipótese de partida é que a paisaxe actúa a xeito de catalizador, de elemento vertebrador da crecente conflitividade de carácter territorial -e en boa medida tamén ambiental- palpable na nosa sociedade. Fronte á perda da idiosincrasia territorial local, debida a procesos que careceron de consenso e ás máis das veces foron mal explicados, a sociedade civil reacciona de maneira cada vez máis indignada, xerando un estado de opinión que conecta perfectamente cunha corrente de fondo que reclama, desde hai anos, unha nova cultura do territorio. Vexámolo con algo máis de detalle.

Non hai dúbida de que, durante as últimas décadas e nun período moi curto de tempo, modificamos o territorio como nunca antes foramos quen de facelo e, en xeral, isto non redundou nunha mellora da calidade da paisaxe, senón máis ben en todo o contrario. Temos asistido a un empobrecemento paisaxístico que botou pola borda boa parte da idiosincrasia de moitas das nosas paisaxes. Durante este período, a dispersión do espazo construído provocou unha fragmentación territorial de consecuencias ambientais e paisaxísticas preocupantes, agravadas polo abandono da actividade agraria. O crecemento urbanístico desorganizado, espacialmente incoherente, desordenado e desligado dos asentamentos urbanos tradicionais ten destruído a lóxica territorial de moitos recunchos do país. Isto, xunto coa implantación de determinados equipamentos e infraestruturas pesadas e mal deseñadas, así como a xeneralización dunha arquitectura de baixa calidade estética -en especial nalgunhas áreas turísticas-, xerou unhas paisaxes mediocres, dominadas cada vez máis pola homoxeneización e a trivialidade. A uniformización e a falta de calidade e orixinalidade dos tipos de construcións maioritarias propiciou en moitos lugares unha paisaxe insensible, aburrida e sen o menor interese, sobre todo nos espazos suburbanos, fronteirizos, de transición, nos que a sensación de caos e de desconcerto se vive con máis intensidade. Nos últimos decenios asistimos, sen dúbida ningunha, á emerxencia de territorios sen discurso e de paisaxes sen imaxinario, o que tivo repercusións clarísimas na perda da identidade territorial, como xa vimos, e mesmo no benestar individual e social, incluso no tocante á saúde. En efecto, ultimamente está tomando forza unha nova liña de investigación (Observatori del Paisatge, 2008; Vallerani e Varotto, 2005) que relaciona o estado de saúde 
física e mental dos cidadáns co feito de vivir ou non rodeados por unhas paisaxes de calidade, harmónicas, ben ordenadas e xestionadas, segundo a filosofía que inspira o Convenio Europeo da Paisaxe, cando recoñece, explicitamente, que «a paisaxe é un elemento importante da calidade de vida das poboacións, tanto nos medios urbanos como nos rurais, tanto nos territorios degradados como nos de gran calidade, tanto nos espazos singulares como nos cotiáns». A paisaxe, conclúe o Convenio, «constitúe un elemento esencial do benestar individual e social».

Sexa como queira, nunca foramos quen de consumir tanto territorio en tan poucos anos e nunca transformaramos este territorio con tal rapidez. Cando a paisaxe se transforma con esta intensidade e a esta velocidade, prodúcense dous efectos perversos. Por unha banda, o risco de destrución da devandita paisaxe é moi alto, posto que se poden eliminar de golpe, como así ten acontecido en moitos casos, aquelas características que lle deron personalidade e continuidade histórica. Cando isto sucede, estamos a falar, claramente, de «destrución» da paisaxe e non de evolución gradual e pausada desta. É moi difícil alterar, modificar e intervir á velocidade e intensidade imperantes nos últimos anos sen ocasionar esa destrución. O outro efecto é de carácter máis ben psicolóxico. Seguindo a Eugenio Turri, «as modificacións da paisaxe no pasado adoitaban ser lentas, pacientes, ao ritmo da intervención humana, prolongadas no tempo e facilmente asimiladas pola natureza dos seres humanos: o elemento novo inseríase gradualmente no cadro psicolóxico da xente. Pero cando esta inserción é rápida, como nos últimos anos, a absorción faise moito máis difícil» (Turri, 1979, p. 36), por non dicir imposible, engado eu. Aparece, daquela, unha crecente sensación de divorcio entre as paisaxes que imaxinamos e as que vivimos (Nogué, 2006). Dito doutro xeito, o abismo entre as paisaxes contempladas diariamente e as paisaxes de referencia transmitidas de xeración en xeración, a través de vías tan diversas como a pintura, a fotografía, os libros de texto ou os medios de comunicación, é cada vez maior. Asistimos a una crise de representación entre unhas paisaxes de referencia que, nalgúns casos, se converteron en auténticos arquetipos e as paisaxes reais, cotiás, que, para unha boa parte da poboación, son precisamente as paisaxes fortemente transformadas que perciben día a día. Parece evidente que se esta crise de representación saíu á luz é debido a que, alén dos núcleos urbanos compactos, non fomos quen de dotar de identidade -a que 
sexa- unhas paisaxes caracterizadas en boa medida pola súa mediocridade e banalidade. Non conseguimos crear novos arquetipos paisaxísticos ou, polo menos, novas paisaxes dotadas de forte personalidade e intensa carga simbólica, en especial nos contornos máis degradados e fracturados. Temos proposto intervencións paisaxísticas que non foron moito máis alá da pura xardinaría, porque non estaban dotadas dun novo discurso territorial e, xa que logo, non fomos quen de experimentar novos usos e canons estéticos. Poida que faltase imaxinación, creatividade ou sentido do lugar, pero o certo é que, con honrosas excepcións, non conseguimos crear novas paisaxes coas que a xente se identificase, novas paisaxes de referencia; non logramos, en definitiva, reinventar unha dramaturxia da paisaxe, seguindo aquí a Paul Virilio.

Por outra parte, as transformacións territoriais descritas máis arriba provocaron que os lugares estean perdendo os seus límites, o que ten moito que ver co que aquí estamos a comentar. Ata hai moi poucas décadas, os distintos usos do solo tiñan uns límites relativamente nítidos e podíase percibir sen demasiada dificultade onde remataba a cidade e onde empezaba o campo. $\mathrm{Na}$ actualidade, a estrutura e morfoloxía da paisaxe da meirande parte do territorio -tamén o rural, aínda que menos- caracterízase por unha alta fragmentación. A zonificación propia da paisaxe tradicional transformouse radicalmente e derivou cara a unha gran dispersión de usos e de cubertas do solo. A antiga zonificación esvaeceuse, perdeuse a claridade na delimitación zonal, o seu carácter compacto rompeuse e impúxose unha paisaxe moito máis complexa, unha paisaxe de transición, híbrida -ou mellor «transxénica»?-, cuxa lóxica discursiva é de máis difícil aprehensión, ata o punto de que nos obriga a preguntarnos con frecuencia se o genius loci correspondente non fuxiu dela; se non teremos cambiado realmente de lugar, de país, parafraseando a excelente obra de David Lowenthal O pasado é un país estraño (1998). De feito, cando se observan con detemento os fotogramas do famoso «voo americano» de 1956, un ten realmente a sensación de estar contemplando outro territorio, de terse equivocado de país.

Os procesos aos que aquí aludimos teñen xerado unhas paisaxes de fronteira difusa, aos que algúns teóricos anglosaxóns xa bautizaron como sprawlscapes ou paisaxes da dispersión; paisaxes que ocupan amplas extensións de territorio en forma de manchas de aceite e que transmiten unha nova concepción do espazo e mais do tempo. A lexibilidade semiótica destas paisaxes contemporáneas some- 
tidas a intensas transformacións é moi complexa. Non é nada fácil descodificar os seus símbolos. É máis complicado entender estas novas paisaxes que a paisaxe urbana compacta, aquela que aprendemos da semioloxía urbana. No seu xa clásico tratado sobre a imaxe da cidade, Kevin Lynch (1960) resaltaba cinco categorías esenciais para a lectura da paisaxe urbana convencional: sinais, nodos, sendeiros, lindeiros e áreas homoxéneas. Que categorías, que claves interpretativas permitirían ler hoxe a paisaxe da dispersión, o sprawlscape? Seguramente existen, e máis pensadas para ser lidas en coche que non andando, pero son, sen dúbida, máis efémeras que as propostas por Kevin Lynch e máis difíciles de interpretar. Non é doado integrar nunha lóxica discursiva clara e comprensible os territorios fracturados e desdebuxados destas paisaxes de fronteira, que alternan, sen solución de continuidade, acaroados, terreos intersticiais, ermos e abandonados, polígonos industriais ou simulacros deles, vivendas dispersas, edificacións efémeras, vertedoiros incontrolados, cemiterios de coches, almacéns precarios, liñas de alta tensión, antenas de telefonía móbil, carteis publicitarios -ou os seus restos-, descampados intermitentes..., en fin, unha desorde xeral, que lle provoca ao cidadán unha desagradable sensación de confusión, de insensibilidade, de desconcerto. Os territorios parecen non posuír discurso e das paisaxes semella terse esfumado o seu imaxinario cando a súa lexibilidade se torna extremadamente complexa, ata o punto de que se achega á invisibilidade. Non nego a posibilidade de que mesmo neste tipo de paisaxes poida un detectar un certo sentido de lugar por parte dos seus habitantes, posto que é verdade que este vén xerado non só polo contorno físico e arquitectónico, senón tamén polas relacións sociais que se dean nel, ou por un evento concreto e mesmo ás veces efémero, pero penso que, cando se perden de golpe o discurso territorial e o imaxinario paisaxístico habituais dunha porción do espazo concreta, o seu sentido de lugar queda sen dúbida afectado.

As transformacións territoriais descritas e os seus correspondentes impactos paisaxísticos, xunto coa devandita crise de representación, están na base da reacción suscitada en moitos sectores da sociedade civil, que se organizaron, autónoma e espontaneamente, en infinidade de plataformas e colectivos, por poñer só un exemplo desta reacción suscitada. A proliferación destas plataformas en defensa do territorio é un fenómeno social extraordinariamente interesante, que, ademais, se dá nuns momentos de escasa participación nas estrutu- 
ras políticas convencionais e que vai moito máis alá da explosión ecoloxista e minoritaria de fins dos setenta e principios dos oitenta, posto que agora agrupa a colectivos nada minoritarios e a persoas da máis variada procedencia. Dada a súa relevancia, sorprende que a estas alturas o fenómeno aínda non se estudara en profundidade, se exceptuamos algunhas recentes aproximacións ao tema (Alfama et al., 2007; García, 2003; e Nel.lo, 2003).

Alén das dinámicas propias e intransferibles de todos os conflitos territoriais hoxe existentes e das correspondentes plataformas cívicas orixinadas, o certo é que a extensión deste tipo de conflitividade obedece a unha serie de factores comúns. En primeiro lugar, e como xa dixemos, a crecente importancia do lugar e das identidades territoriais nun contexto de globalización galopante, que produciu unha tensión dialéctica entre o local e o global, non sempre resolta de forma satisfactoria. En segundo lugar, unha crise de confianza nas institucións e nos sistemas de representación política convencionais, ao non atopar neles nin a resposta esperada nin a adecuada. Finalmente, unhas políticas territoriais -e tamén ambientais-, con frecuencia mal deseñadas e, sobre todo, mal explicadas. Son habituais as descualificacións deste tipo de movementos e de plataformas, acusados desde o establishment de insolidariedade territorial e de responder a un certo romanticismo infantil e a unha "cultura do non" incapaz de asumir con responsabilidade os inevitables custos que supón o progreso. Así e todo, ao meu ver, as cousas son bastante máis complicadas.

Estes novos movementos sociais teñen moito que ver cos procesos de globalización e coas súas incertezas, así como coa sensación de inseguridade e impotencia que xeran no individuo. Asistimos, en efecto, a unha especie de «retorno ao lugar», expresión que non quere indicar máis que a crecente importancia que ten o lugar e a súa identidade no mundo contemporáneo. Aínda que o espazo e o tempo se comprimiron, as distancias se relativizaron e as barreiras espaciais se suavizaron, os lugares non só non perderon importancia, senón que aumentaron a súa influencia e o seu peso específico nos ámbitos económico, político, social e cultural. Baixo unhas condicións de máxima flexibilidade xeral e de incremento da capacidade de mobilidade por todo o territorio, tanto os sectores económicos como os axentes políticos e sociais teñen que prestarlles máis atención que nunca ás particularidades do lugar. As pequenas -ou non tan pequenas- diferenzas que poidan presentar dous lugares no tocante aos seus 
recursos, infraestruturas, mercado laboral, paisaxe ou ao patrimonio cultural, por poñer só uns exemplos, resultan agora moi significativas.

«Pensar globalmente e actuar localmente» converteuse nunha consigna fundamental e satisfactoria tanto para os grupos ecoloxistas como tamén para as empresas multinacionais, os planificadores das cidades e das rexións e os líderes políticos. En efecto, «o local e o global entrecrúzanse e forman unha rede en que ambos os dous elementos se transforman como resultado das súas mesmas interconexións. A globalización exprésase a través da tensión entre as forzas da comunidade global e as da particularidade cultural» (Guibernau, 1996, p. 146). Máis aínda, o lugar actúa a xeito de vínculo, de punto de contacto e interacción entre os fenómenos mundiais e a experiencia individual. Así pois, a expresión GLOCAL - de GLObal e loCAL- converteuse nun neoloxismo de moda.

Sexa o que sexa o punto de vista escollido, o certo é que o lugar reaparece hoxe con forza e vigor. A xente defende, cada vez con máis insistencia e de forma máis organizada, as súas raíces históricas, culturais, relixiosas, étnicas e territoriais. Reafírmase, noutras palabras, nas súas identidades singulares. Como indica Manuel Castells (1998), os movementos sociais que cuestionan a globalización están baseados, fundamentalmente, na identidade e defenden os seus lugares fronte á nova lóxica dos espazos sen lugares, dos espazos de fluxos propios da era da información na que estamos inmersos. Reclaman a súa memoria histórica, a vixencia dos seus valores e o dereito a preservar a súa propia concepción do espazo e mais do tempo. A sensación de indefensión, de impotencia, de inseguridade fronte a este novo contexto de globalización e internacionalización dos fenómenos sociais, culturais, políticos e económicos provoca un retorno aos microterritorios, ás microsociedades, ao lugar, en definitiva. A necesidade de sentirse identificado cun espazo determinado é agora sentida de novo con intensidade, sen que iso signifique volver inevitablemente a formas premodernas de identidade territorial.

Se un atende a este fenómeno de «retorno ao lugar» que vimos de describir e o une ao potente e conxuntural «neodesenvolvemento» en que o país leva inmerso nestes últimos anos, non debería estrañarse do malestar territorial que nos afecta e que, curiosamente, se asimila e se «somatiza», na meirande parte dos casos, a través da paisaxe. O diagnóstico é claro; a solución, algo máis complexa, pero non imposible, como veremos a continuación. 


\section{SENTIDO DE LUGAR E INTERVENCIÓN NA PAISAXE}

A través dalgúns exemplos concretos desexaría mostrar que non é quimera ningunha considerar o sentido de lugar nunha planificación territorial de carácter paisaxístico. As reflexións realizadas ata o de agora poden trasladarse perfectamente ao ámbito da intervención, evitando no posible caer nalgúns dos riscos máis habituais nese intento, en concreto o da «museización» das paisaxes ou, o que é aínda peor, a súa «tematización»e «turistificación», riscos en que non vou entrar porque son coñecidos dabondo.

Existen varias propostas metodolóxicas xa ensaiadas e aplicadas en diferentes instrumentos de planificación territorial que foron capaces de introducir, dun ou doutro xeito, o sentido de lugar na ordenación da paisaxe. Referireime a algunhas delas, empezando non pola máis relevante, senón pola que coñezo máis a fondo: os catálogos de paisaxe de Cataluña.

Os catálogos de paisaxe, que participan da filosofía do Convenio Europeo da Paisaxe, son uns documentos de carácter técnico que a Lei de Protección, Ordenación e Xestión da Paisaxe de Cataluña concibe como ferramentas para a ordenación e a xestión da paisaxe desde a perspectiva da planificación territorial. Determinan a tipoloxía das paisaxes de Cataluña, os seus valores - patentes e latentes- e o estado de conservación, os obxectivos de calidade que deben cumprir e as medidas que cómpre adoptar para conseguilo. Son, xa que logo, unha ferramenta extremadamente útil para a aplicación de políticas de paisaxe coa conivencia e participación activa de todos os axentes sociais que interveñen no territorio, algo que se consegue sobre todo a través da integración de obxectivos paisaxísticos nas estratexias territoriais. Este último aspecto é importante en canto que implica a sociedade catalá no seu conxunto na xestión e planificación da súa propia paisaxe.

O procedemento para a elaboración dos catálogos de paisaxe aplícase en catro fases: identificación e caracterización da paisaxe; avaliación da paisaxe; definición de obxectivos de calidade paisaxística; e establecemento de directrices, medidas e propostas de actuación. Das catro fases, as tres primeiras teñen moitísimo que ver co sentido de lugar. No fondo, a primeira fase -a de identificación e caracterización da paisaxe- pode resumirse nun intento de captación do sentido de lugar, xa que nela non se establece unha tipoloxía de paisaxes, senón que se «identifican» paisaxes, entendidas estas de maneira integral, como a síntese de factores 
naturais e culturais. A paisaxe é entendida nos catálogos como unha realidade física e a representación que culturalmente nos facemos dela; como a fisionomía xeográfica dun territorio, con todos os seus elementos naturais e antropolóxicos e tamén os sentimentos e emocións que espertan no momento de contemplalos; como un produto social, a proxección cultural dunha sociedade nun espazo determinado. As unidades de paisaxe resultantes deste proceso queren ser, en última instancia, exemplos tanxibles dos diversos sentidos de lugar.

Para chegar a captar o sentido de lugar é fundamental a participación pública, o mecanismo mediante o que os cidadáns se implican no deseño da paisaxe que queren e contribúen a decidir sobre as políticas que se aplican. E esta implicación materialízase, sobre todo, a través dos denominados obxectivos de calidade paisaxista, para cuxa consecución é fundamental, novamente, a consideración do sentido de lugar, que se pode detectar a través de múltiples vías, que no caso concreto dos catálogos foron catro: a entrevista en profundidade, unha enquisa vía web, sesións de debate e sesións informativas. Todos estes mecanismos de participación foron moi útiles para identificar os valores intanxibles da paisaxe, así como os seus valores simbólicos e identitarios, todos eles claves para acceder ao sentido de lugar.

En efecto, os instrumentos de ordenación territorial que tomen en serio o sentido de lugar non poden prescindir dos valores intanxibles, inmateriais, presentes en toda paisaxe, porque ás veces son decisivos. Vou mostrar este aspecto recorrendo a unha simple noticia aparecida na prensa, que non é especialmente relevante, aínda que si significativa no contexto desta intervención. Como xa se sabe, o Ministerio de Medio Ambiente vetou hai un par de anos o proxecto do gran dique e porto exterior de Ciutadella, en Menorca, polo seu forte impacto paisaxístico, entre outras razóns. Tratábase, en efecto, dun proxecto faraónico que incluía un dique en forma de media lúa e dous embarcadoiros en mar aberto de 740 metros de lonxitude diante da actual bocana. Parece ser que, finalmente, aínda que sen o consenso desexable e logo dalgunhas modificacións no proxecto inicial, a ampliación do porto será realizada. O que me interesa comentar agora é unha das alegacións presentadas. Habitualmente, as obxeccións contra este tipo de infraestruturas nos correspondentes períodos de exposición pública adoitan ser máis ben de carácter técnico e xurídico, e así o foi tamén neste caso. Non obstante, unha das alegacións que máis soporte recibiu tiña un 
carácter totalmente diferente e dicía así: «Un dos principais atractivos do porto de Ciutadella é a súa gran beleza. A imaxe do contorno da entrada do porto, aínda sen transformar, constitúe un patrimonio de primeira orde que Ciutadella ten que conservar. A construción dun dique na bocana cambiaría radicalmente a actual vista cara ao mar desde a cidade e faría que se perdesen para sempre espectáculos de gran beleza, como os solpores».

Non é, en efecto, un argumento técnico, nin tampouco xurídico. Non precisa de soporte teórico ningún, nin se sustenta en premisa científica ningunha, no sentido máis literal da palabra. E, así e todo, malia a súa aparente futilidade e mesmo, para algúns, trivialidade, ten unha forza e unha transcendencia enormes: é a forza dos intanxibles.

Agora ben, como se avalía a contemplación do solpor? Como se mide o mal inflixido aos cidadáns pola eliminación da posibilidade de contemplar esta escena ao implantar no horizonte, de golpe, unha infraestrutura das dimensións antes comentadas? Como se poden incorporar, en definitiva, os elementos intanxibles na xestión, ordenación e protección da paisaxe? Non é doado, certamente. Abundan as metodoloxías cuantitativas e de inspiración neopositivista, pero de pouco serven para o tema que aquí nos ocupa, de difícil, por non dicir imposible, cuantificación, a non ser que deamos por válidas as ficticias e insípidas correspondencias numéricas que ás veces se lles outorgan de maneira mecánica aos valores intanxibles da paisaxe. Pero tamén é verdade que, con frecuencia, non hai máis remedio que recorrer a estas metodoloxías, aínda que sexa para saír do paso, porque o certo é que andamos bastante escasos de metodoloxías de carácter cualitativo que, sen pedir imposibles, acheguen un pouco de luz sobre como identificar e avaliar os elementos intanxibles da paisaxe cun mínimo de obxectividade e, xa que logo, de posible consenso.

O seminario sobre indicadores de paisaxe que o Observatori del Paisatge organizou en Barcelona a finais de novembro do pasado ano permitiu confrontar e poñer enriba da mesa diferentes propostas metodolóxicas ao respecto, procedentes de diversos países e disciplinas. Unha das agradables conclusións do seminario foi a constatación de que, nos últimos anos, se ten avanzado moito no tratamento e consideración dos valores intanxibles. O Landscape Research Group da Universidade de Newcastle, por poñer un exemplo exposto no seminario, afinou moitísimo os métodos de identificación e avaliación dun valor tan 
complexo e aparentemente pouco obxectivo como é a tranquilidade, que mesmo se atreveu a cartografar nos, cada vez máis coñecidos e utilizados, Tranquillity Maps, nunha liña moi similar ao indicador de «satisfacción paisaxística» que estamos a elaborar desde o Observatori del Paisatge. Para chegar a estes resultados, combináronse sofisticados sistemas de información xeográfica con métodos cualitativos moi centrados en entrevistas en profundidade - Participatory Appraisal- que permiten coñecer as percepcións da poboación local, os seus valores e as súas crenzas verbo da tranquilidade. Pero o máis interesante é que, finalmente, un valor intanxible tan subxectivo e complexo como este foi recoñecido e tomado en conta por axencias gobernamentais inglesas tan prestixiosas como a Countryside Agency ou The Forestry Comission.

Tamén de Inglaterra procede outra experiencia moi ilustrativa no tocante á consideración do sentido de lugar en proxectos de ordenación e xestión da paisaxe. Refírome á iniciativa Countryside Quality Counts (CQC), que emana do Rural White Paper (2000), unha especie de libro branco sobre os espazos rurais ingleses e que se dedica a seguir, de xeito pormenorizado, as transformacións das zonas rurais inglesas. Pois ben, a atributos como a biodiversidade ou a tranquilidade, que xa vimos, engadíuselles un que se denominou "carácter da paisaxe». Nunha liña moi semellante ao proceso de delimitación de unidades de paisaxe dos catálogos de Cataluña xa comentados, logrouse debuxar un mapa de Inglaterra dividido en 156 paisaxes, denominado Character Areas Map of England, tamén presentado no seminario de Barcelona do que xa falamos. Gustaríame resaltar o feito de que o Countryside Quality Counts é un proxecto aplicado que responde a unha política de paisaxe, e non un simple exercicio académico. E, así e todo, o proxecto non ten reparo ningún en falar abertamente do carácter da paisaxe e do sentido de lugar por parte dos habitantes de cada unha destas 156 áreas xeográficas delimitadas que cobren toda Inglaterra. Unha das conclusións referidas ao período 1999-2003 indicaba que o carácter da paisaxe existente mantivérase no $51 \%$ destas unidades e mesmo mellorara nun $10 \%$ delas, que un $20 \%$ das paisaxes inglesas se degradaran e que un $19 \%$ estaba sumido nunhas novas dinámicas que transformarían en breve o seu carácter.

Outro exemplo interesante, no que non podo entrar por falta de espazo, é a estratexia federal suíza Paisaxe 2020, que incorpora na súa ampla lista de indicadores de paisaxe os de carácter estético, artístico e simbólico, a carón doutros 
máis convencionais, no sentido de que son máis fáciles de cuantificar, como os usos do solo ou os habitualmente utilizados pola ecoloxía da paisaxe.

A novidade e o interese destas e doutras iniciativas similares está en que, por primeira vez, incorporan ao estudo da paisaxe e aos seus instrumentos de xestión e ordenación valores e indicadores intanxibles en sintonía coa filosofía que inspira ultimamente a política das institucións internacionais de protección do patrimonio cultural. Agora ben, se no contexto da xestión patrimonial a intanxibilidade é un concepto amplo e complexo, e non sempre de fácil aplicación ás políticas culturais, moito máis complicada resulta a súa aplicación ás políticas territoriais e de paisaxe. De aí o mérito das experiencias que veño de comentar.

\section{A XEITO DE CONCLUSIÓN}

Como indicaba ao principio, o tema das relacións entre a paisaxe e o sentido de lugar non é doado, pois resulta arriscado, desde un punto de vista metodolóxico, e escorregadizo, desde unha perspectiva ideolóxica e política. Non obstante, penso que a cuestión é clave, tanto porque estivo, está e seguirá a estar na esencia mesma do debate nacionalista, como porque, alén deste debate e a escala cotiá, nos permite entender algo mellor a conflitividade territorial contemporánea no marco da complexa e poliédrica tensión dialéctica entre o local e o global. E, non só nos permite entender esta conflitividade, senón que nos proporciona ideas para rebaixala. Temos visto, a título de exemplo, algunhas propostas de protección, ordenación e xestión da paisaxe que incorporaron estas ideas en forma de accións concretas. É posible, xa que logo, aplicalas. E farase con éxito cando se realice no marco dunha nova cultura territorial que mellore a gobernabilidade das políticas territoriais, que contemple os procesos non estruturados de participación cidadá e que reflexione a fondo sobre os xa existentes, incidindo moito máis na cooperación, a participación e a xestión concertada. A conflitividade territorial contemporánea, expresada a través da paisaxe, reflexa en boa medida o medo a perder o propio sentido de lugar. Cómpre, xa que logo, garantirlle ao cidadán que non perderá este sentido de lugar, que a súa paisaxe evolucionará e se transformará conservando o seu carácter, e que, no caso de que este deba variar, o fará coa súa conformidade e participación. 


\section{BIBLIOGRAFÍA}

Alfama, E. et al.: Per una nova cultura del territori?, Barcelona, Icària, 2007.

Branch, M. (ed.): National History and Identity. Approaches to the Writing of National History in the North-East Baltic Region. Nineteenth and Twentieth Centuries, Helsinki, Finnish Literature Society, 1999.

ButTIMER, A.: Sociedad y medio en la tradición geográfica francesa, Barcelona, Oikos-Tau, 1980.

CASASSAS I SIMÓ, L.: «Pau Vila en l'evolució de la geografia catalana», en Divisió Territorial de Catalunya, La. Selecció d'escrits de geografia de Pau Vila, I, Barcelona, Curial, 1979, p. 5-24.

CASTELls, M.: La era de la información: economía, sociedad y cultura, 3 vol., Madrid, Alianza Editorial, 1998.

GaRCíA, J.: Territorio y nacionalismo. La construcción geográfica de la identidad gallega, Santiago de Compostela, 2002.

GARCía, X.: Catalunya es revolta, Barcelona, Angle Editorial, 2003.

GuibernaU, M.: Los nacionalismos, Barcelona, Ariel, 1996.

LOWENTHAL, D.: El pasado es un país extraño, Madrid, Akal, 1998.

LuginbüHL, Y.: Paysages. Textes et représentations du paysage du siècle des Lumières à nos jours, Paris, La Manufacture, 1989.

LYNCH, K.: The Image of the City, Cambridge, The Massachussetts Institute of Technology Press, 1960. [Hai edición en castelán].

Maragall, J.: Obres completes, Barcelona, Editorial Selecta, 1960.

MARTí, J.: L'excursionisme cientific i la seva contribució a les ciències naturals i a la geografia, Barcelona, Empúries, 1994.

NeL.LO, O.: Aqui, no! Els conflictes territorials a Catalunya, Barcelona, Empúries i Càtedra de Geografia i Pensament Territorial de la Universitat de Girona, 2003.

Nogué, J.: Nacionalismo y Territorio, Lleida, Milenio, 1998.

Nogué, J.: «Nacionalismo, territorio y paisaje en Cataluña», en N. Ortega Cantero: Paisaje, memoria histórica e identidad nacional, Madrid, Universidad Autónoma de Madrid e Fundación Duques de Soria, 2005, p. 147-169.

NoguÉ, J.: «La necessària revisió dels paisatges de referència», Nexus, 36, 2006, p. 36-49.

NoGUÉ, J. (ed.): La construcción social del paisaje, Madrid, Biblioteca Nueva, 2007.

Nogué, J. e J. Romero (ed.): Las otras geografías, València, Tirant lo Blanch, 2007.

Nora, P. (ed.): Les Lieux de mémoire, Paris, Gallimard, 1984-1992.

Observatori del Paisatge (ed.): Paisatge i salut, Observatori del Paisatge de Catalunya e Departament de Salut da Generalitat de Catalunya, 2008.

TÖNNIES, F.: Gemeinschaft und Gesellscahft, 1887, tradución catalá: Comunitat i Associació, Barcelona, 1984.

TURRI, E.: Semiologia del paesaggio italiano, Milano, Longanesi, 1979.

Tuan, Y. F.: Topophilia: A Study of Environmental Perception, Attitudes, and Values, New Jersey, PrenticeHall, 1974. [Hai edición en castelán].

TuAN, Y. F.: Space and Place: The Perspective of Experience, Minneapolis, University of Minnesota Press, 1977.

VAllerani, F. e M. VAROTTO (ed.): Il grigio oltre le siepe. Geografie smarrite e racconti del disagio in Veneto, Padova, Nuova Dimensione, 2005. 



\title{
PAISAXE E SENTIDO DE LUGAR NO MUNDO CONTEMPORANEO*
}

\author{
Jacobo García Álvarez
}

Universidad Carlos III de Madrid

* O presente texto recolle as ideas principais da miña intervención no foro de debate que deu orixe a esta publicación, efectuada como réplica ao relatorio de Joan Nogué. Agradézolle a Paloma Puente Lozano, doutoranda da Universidad Carlos III de Madrid, os seus valiosos comentarios e suxestións. 

Centrarei a miña intervención como retrucante neste foro de debate nas dúas primeiras partes do relatorio de Joan Nogué, que forman o corpo principal deste e propoñen algunhas cuestións medulares verbo das relacións entre paisaxe, identidade e sentido de lugar na xeografía e o mundo contemporáneos. Sen restarlle interese á terceira parte do relatorio, algúns dos aspectos e experiencias que alí se propoñen foron abordados tamén por Rafael Mata, de aí que prefira determe estritamente neses dous primeiros apartados. Vaia por diante que coincido en moitos aspectos coas teses de Joan, polo que as consideracións que presentarei a continuación non constitúen propiamente unha discrepancia respecto das súas ideas e argumentos, senón unha reflexión que, partindo deles, pretende desenvolver e incidir en diversos asuntos e, nalgún caso, presentar certas dúbidas e interrogantes abertos que me parecen relevantes en relación cos temas obxecto do devandito relatorio e do presente foro.

Unha das ideas centrais da primeira parte da intervención de Joan fai referencia á cuestión dos arquetipos paisaxísticos nacionais, das paisaxes nacionais elixidas ou seleccionadas polos ideólogos nacionalistas ou rexionalistas, por estimar que condensan e simbolizan, mellor que calquera outra, as identidades territoriais respectivas. Isto é un feito xeneralizado nos nacionalismos e na práctica totalidade dos Estados europeos, sobre todo no século XIX e durante o primeiro terzo do XX, e o propio Joan Nogué teno estudado en detalle para o caso de Cataluña e certas paisaxes e lugares de montaña. Eu non vou insistir aquí, porque non hai espazo para iso, na extensa casuística de estudos que, en especial nos últimos dous decenios, indagaron verbo dese tipo de paisaxes «identitarias», tanto dentro como fóra de España, e sobre os que xa existen algúns balances e obras comparativas e de conxunto de publicación recente (Walter, 2004; e García Álvarez, 
2008). Pero si desexaría facer varios incisos e reflexións no tocante á idea de «paisaxe nacional».

a) Como xa dixo o profesor Nogué, a integración da paisaxe nos procesos de construción nacional e a definición de arquetipos ou iconas paisaxísticas nacionais son asuntos certamente conflitivos, por varias razóns. Algunhas xa as apuntou o relator, pero aquí paréceme preciso resaltar unha que non sinalou, aínda que si estudou nalgún traballo anterior relacionado tamén co caso catalán: o feito de que, alén do horizonte puramente teórico ou conceptual, estes arquetipos e símbolos teñen consecuencias materiais, na medida en que modelan as actitudes individuais, colectivas e institucionais cara á paisaxe, estimulando, segundo os casos, a súa protección ou o seu abandono, a súa conservación ou a súa transformación drástica, ou, en fin, a súa apreciación como patrimonio colectivo, cando a valoración é positiva, pero tamén a súa degradación ou mesmo a súa destrución, cando a valoración que se lle outorga resulta negativa ou indiferente.

A historia das políticas de protección da natureza, que en gran medida foron formas de «institucionalización da paisaxe», reflicte ben o peso deses arquetipos na sorte desigual que sufriron as paisaxes no último século, con consecuencias ás veces irreparables. O propio Nogué destacouno con claridade no caso de Cataluña, onde o arquetipo da montaña, como símbolo de identidade nacional acuñado no XIX, foi mantido polo nacionalismo máis conservador actual, que, durante os máis de vinte anos nos que presidiu o goberno da comunidade autónoma, asumiu, apoiou ou impulsou a protección de novos espazos de montaña -Aigüestortes, Montserrat, o Val de Nuria e o Montseny-, ao tempo que se desprezaban e abandonaban á especulación e ao desenvolvemento máis desaforado as paisaxes da Cataluña do sur ou, en xeral, da Cataluña chá e a súa costa, a Cataluña da conca do Ebro, paisaxes desprovistas desa valoración identitaria oficial e, xa que logo, carentes practicamente ata hai pouco tempo de protección política (Nogué, 2005).

b) Por outra parte, a integración da paisaxe nos procesos de construción nacional e a definición de arquetipos ou iconas paisaxísticas nacionais resultan con frecuencia obxectos de disputa política e ideolóxica cando as realidades nacio- 
nais son complexas e plurais, ou cando coexisten diferentes concepcións políticas e ideolóxicas do nacional. En moitos países ou rexións, a selección dunha determinada paisaxe como arquetipo, como expresión dunha «esencia» colectiva, supón necesariamente un reducionismo que, por unha banda, pode servir para unir unha parte máis ou menos ampla da comunidade política, dotándoa duns símbolos compartidos, pero que, por outra, tamén pode significar que se marxina o resto desa comunidade, ou outros territorios desta, na medida en que poidan non sentirse representados polos devanditos arquetipos.

c) Non quero dicir con isto que a apropiación nacionalista da paisaxe sexa necesariamente algo negativo e perverso. Pola contra, nalgúns sentidos, o nacionalismo, ao integrar a paisaxe no seu imaxinario e conectala estreitamente co sentido de lugar, contribuíu de maneira positiva á valoración, ao descubrimento intelectual e á patrimonialización das paisaxes baixo fórmulas políticas diversas, como a declaración de espazos naturais protexidos, a protección de conxuntos históricos e monumentais, ou, máis recentemente, a promulgación de leis específicas sobre a paisaxe. Pero, por outro lado, o uso e a defensa de arquetipos nacionais paisaxísticos tivo e pode ter tamén manifestacións moito máis espurias e perversas, ás veces de forma extrema, cando estes arquetipos que serven para definir e integrar a comunidade propia se usan ao servizo de concepcións nacionais esencialistas, excluíntes, integristas e mesmo xenófobas. $\mathrm{O}$ exemplo modélico desa perversión da idea de paisaxe nacional -e máis amplamente da propia noción de sentido de lugar- atoparémolo en certos réximes totalitarios do século XX, pero tamén pode apreciarse, en máis ou menos grado, noutros contextos ou opcións plenamente democráticos.

Como en tantos outros casos, o uso do concepto de paisaxe nacional que fixo o nacional-socialismo na Alemaña de Entreguerras, analizado por Walter no libro antes citado (2004, en especial, p. 430-465), ofrece un exemplo extremo, ou máis ben un contraexemplo, das perversións ás que pode conducir a instrumentalización nacionalista de certos conceptos de carácter espacial e, aínda que sexa brevemente, non me parece que estea de máis lembralo a propósito do relatorio obxecto deste comentario. Integrada na teoría ratzeliana do espazo vital, a idea de que a identidade alemá estaba estreitamente ligada a un determinado tipo de paisaxe non só serviu daquela para xustificar o expansionismo alemán 
cara ao leste e para incorporar as áreas - poboadas, de facto ou non, por minorías étnicas alemás- que conservaban na súa paisaxe algunha pegada histórica da cultura alemá. Serviu tamén para organizar, iniciada a II Guerra Mundial e en vastas extensións de Polonia, Ucraína ou Lituania, auténticas políticas de colonización e reasentamento masivo de pobos -incluídos, como é sabido, o exterminio ou a deportación de certos grupos, en especial de xudeus e eslavos, substituídos por colonos alemáns- coa premisa de modelar ou de remodelar as súas paisaxes segundo os arquetipos nacionais considerados como xenuinamente xermánicos.

Non pretendo, en absoluto, extrapolar este exemplo extremo ás prácticas dos nacionalismos e réximes políticos democráticos pasados ou actuais, pero si creo que, canto menos, as concepcións «esencialistas» da paisaxe e a tentación de desenvolvelas no terreo político latexan e abrollan periodicamente neste xénero de discursos e que debemos estar vixilantes fronte a este tipo de concepcións e tentacións.

d) É certo que a construción da paisaxe como símbolo de identidade foi acometida sobre todo no seo de procesos de construción rexional e nacional, aínda que, como comentou Joan Nogué, tamén hai discursos identitarios que incorporan a paisaxe a nivel local de forma relevante. Neste sentido, paréceme interesante, pola súa maior ambición e novidade, mencionar outros discursos, propostas e políticas que trataron ou tratan de resaltar o valor identitario e patrimonial da paisaxe no marco de referentes xeográficos máis extensos que o Estado ou a rexión.

A escala continental, por exemplo, cómpre lembrar que a Convención Europea da Paisaxe lle atribúe a esta ou ben recoñece nela, entre outros, este tipo de valores simbólicos e patrimoniais: «a paisaxe [reza o seu preámbulo] contribúe á formación das culturas locais e é un compoñente fundamental do patrimonio natural e cultural europeo, que contribúe ao benestar dos seres humanos e á consolidación da identidade europea». Como é sabido, a propia Convención estimulou de forma directa a elaboración de catálogos e atlas de paisaxes a diversas escalas, aos que se teñen referido amplamente no presente foro, tanto o relatorio de Joan Nogué como o de Rafael Mata. O borrador inicial da devandita Convención, aprobado pola Resolución 53/97 do Consello de Europa e asumi- 
do, dentro deste organismo, polo Congreso de Poderes Locais e Rexionais de Europa en maio de 1998, prevía mesmo a elaboración dunha «Lista de Paisaxes de Significación Europea» (Consello de Europa, 1998), aínda que esta previsión foi excluída do texto finalmente aprobado en Florencia en outubro de 2000.

Pero a iniciativa institucional sen dúbida máis importante ata o de agora na consideración dos valores patrimoniais da paisaxe a escala supranacional, e que inspiraba en boa medida a iniciativa antes comentada, segue a ser a creación e o desenvolvemento, desde 1992, da figura da "paisaxe cultural» dentro da Convención sobre a Protección do Patrimonio Mundial Natural e Cultural da UNESCO. Segundo esta, corresponden a esta categoría aquelas paisaxes cuxa representatividade e valor patrimonial se poden medir e valorar a escala mundial, ou dito textualmente, "creacións combinadas da natureza e mais do home» que «ilustran a evolución da sociedade e dos asentamentos humanos ao longo da historia». Como xa mostraron algúns estudos recentes, a análise xeográfica dos lugares que forman parte desa categoría e, máis amplamente, do conxunto da Lista do Patrimonio Mundial, atendendo á súa localización, á súa extensión e, por suposto, aos criterios en que se fundamentou a súa declaración, puxo de manifesto a importancia identitaria de moitas destas paisaxes a diversas escalas e identificou certas pautas e dinámicas interesantes para os efectos das cuestións obxecto do relatorio (Roudié, 2002; e Van Gorp e Renes, 2007).

No caso de Europa, por exemplo, cómpre destacar, en primeiro lugar, a progresiva ampliación da noción de patrimonio desde concepcións exclusivamente artísticas e arqueolóxicas, concentradas nos ámbitos urbanos, cara ás visións que incorporan outras dimensións -como as naturais e, con carácter máis recente, as agrarias e industriais- e valoran a paisaxe como síntese e testemuño privilexiado das formas tradicionais de utilización do territorio e, máis amplamente, das relacións históricas entre a sociedade e a natureza. Así mesmo, aínda que, en consonancia co propio procedemento de proposta das declaracións, a Lista da UNESCO reflicte eminentemente as respectivas concepcións nacionais ou rexionais da historia e do patrimonio e foi utilizada con frecuencia como instrumento de "glorificación nacional», resulta interesante a incorporación á devandita lista dalgúns lugares e paisaxes compartidos por dous Estados, así como doutros representativos de fenómenos característicos de conxuntos rexionais máis amplos -como o Báltico, o Mediterráneo, Escandinavia ou a Europa 
oriental-. Lugares e paisaxes que indican a existencia, máis ou menos evidente, de determinados vínculos xeohistóricos profundos entre os pobos destas rexións, e mesmo a vontade de construír historias compartidas e símbolos xeográficos de encontro e de cooperación internacionais.

A segunda parte do relatorio de Joan Nogué meteuse de cheo en cuestións cruciais no debate contemporáneo, recente e actual, sobre a relación entre paisaxe e sentido de lugar e, en particular, sobre as ideas relativas á destrución e á degradación crecentes da paisaxe nos países occidentais, fenómeno en que se adoita incluír a xeneralización de paisaxes cada vez máis estándares, uniformes, caóticas e, en opinión dalgúns autores, escasamente propicias para o desenvolvemento de lazos identitarios e existenciais profundos coas poboacións que as habitan. É difícil cuestionar os argumentos do relator, expostos con sutileza e sentido crítico, fuxindo de tópicos, de simplificacións ou de posturas unívocas. Pero si creo que hai argumentos frecuentes nalgúns dos debates coetáneos sobre paisaxe e sentido de lugar que me suscitan maior dúbida, que requiren un maior matiz, que encerran contradicións importantes ou que están a ser obxecto de revisións recentes máis ou menos audaces, novas e interesantes.

Coincido con Joan Nogué en que existe unha certa incapacidade por parte da Xeografía e doutras disciplinas que se ocupan da paisaxe para analizar e interpretar determinadas transformacións e manifestacións espaciais recentes no mundo occidental que teñen moito que ver coa velocidade dos procesos de globalización e que son difíciles de describir cos esquemas teóricos e conceptuais previos. Houbo, pode afirmarse, unha certa «cegueira xeográfica» na asimilación destas realidades, como a houbo noutros momentos en relación co tratamento dos fenómenos urbanos modernos, que se incorporou moi tardiamente á disciplina. E penso que niso tivo e ten moito que ver unha certa persistencia de interpretacións nostálxicas e idealizadas do pasado respecto do sentido de lugar das paisaxes e as comunidades tradicionais, que en boa parte era froito da necesidade e dun tipo de sociedade premoderna enraizada forzosa e poderosamente no espazo local, así como para comparar este sentido co das sociedades modernas. Pero, ademais, algúns diagnósticos procedentes de interpretacións antropolóxi- 
cas ou xeográficas humanistas en relación con certos espazos característicos das sociedades actuais resultan cada vez máis discutibles e de feito están a ser revisados amplamente na actualidade.

Entre estes diagnósticos sometidos recentemente a revisión figura precisamente a imaxe que autores tan relevantes e influentes nos estudos sobre os lugares e o sentido de lugar nos últimos decenios -antropólogos como Marc Augé, filósofos como Edward Casey ou xeógrafos como Edward Relph, este nas súas obras iniciais, non nas últimas- teñen ofrecido dos espazos máis estreitamente vinculados ao lecer, ao consumo, ao intercambio, á circulación ou á mobilidade en xeral (Relph, 1976; Casey, 1993; ou Augé, 1993; para facer un balance recente destes estudos, véxase Puente, 2006). No seo da devandita imaxe, aeroportos, parques temáticos, estradas e grandes vías de comunicación, áreas de servizo, supermercados e grandes centros comerciais ou de lecer, hoteis, etc. foron cualificados de espazos «axeográficos» ou «deslocalizados», deseñados con patróns estándares e estraños ás características específicas do lugar, ou compostos a base de imitar, recrear e combinar fragmentos representativos de múltiples lugares e épocas, como se ten dito tamén de «cidades-casino» como Las Vegas ou de boa parte dos novos espazos residenciais privados que proliferan cada vez máis nas áreas urbanas e suburbanas norteamericanas, e para as que o politólogo Evan McKenzie popularizou a palabra "privatopías».

Máis aínda, cualificáronse moitos deses espazos como «non lugares», como espazos incapaces de xerar formas de identificación, experiencia e sociabilidade auténticas ou densas. Ou como paisaxes sen imaxinario e sen discurso, por expresalo en palabras de Joan Nogué. Pero, son realmente paisaxes sen imaxinario ou sen discurso? E mesmo se o fosen por comparación a outras paisaxes máis arquetípicas e de referencia, pódense cualificar realmente, desde a perspectiva da experiencia, como «non lugares»? Hai verdadeiramente, como di Nogué, un divorcio entre as paisaxes que imaxinamos e as que vivimos?

Neste sentido, penso que cómpre resaltar aquí a profunda revisión crítica que están a realizar algúns autores e certas liñas de investigación recentes que centraron a súa atención nestes espazos. O último libro do filósofo estadounidense David Kolb, titulado Sprawling Places (2008) e centrado nas paisaxes suburbanas norteamericanas, sintetiza ben as teses desa corrente de revisión crítica na que participan, entre outros expertos, xeógrafos, arquitectos, sociólogos, antro- 
pólogos e filósofos como o citado Kolb, e que coincide tamén coa posta en cuestión doutros conceptos firmemente asentados no estudo dos espazos urbanos modernos desde os anos 1960, como os de lexibilidade e habitabilidade (Miles, 2004).

A grandes trazos, Kolb e os autores vinculados a esta liña de revisión criticaron a concepción excesivamente morfolóxica, visual, esteticista, demasiado centrada na paisaxe construída, ou na súa cara externa, que nutre moitas das interpretacións relativas ao sentido de lugar, ou as ideas de lexibilidade e habitabilidade antes citadas, así como o propio concepto de «non lugar», que consideran desafortunado e equívoco. Pola contra, desde a liña representada por estes autores, estase a defender a capacidade de moitos deses chamados «non lugares» para xerar relacións sociais densas, non só de tránsito, de consumo ou de intercambio, senón mesmo como lugares de encontro e identificación para certos grupos; a súa capacidade para estimular imaxinarios e representacións culturais intensas e, en definitiva, para converterse en centros de experiencia e significado máis ou menos profundos para determinados colectivos e individuos, e xa que logo, en lugares no sentido existencial e fenomenolóxico da palabra.

Se pensamos, por exemplo, na cuestión dos imaxinarios, baste citar a importancia da estrada, do motel, da cidade-casino, do parque temático ou, máis recentemente, do aeroporto e o gran centro comercial no cine estadounidense, ao punto de que algunhas desas paisaxes se converteron en certo modo en símbolos da identidade nacional do país. É verdade, e cómpre advertilo de entrada, que o imaxinario territorial dos Estados Unidos, inzado de supostos «non lugares», non se pode extrapolar pura e simplemente á explicación doutras realidades xeográficas e culturais, pero penso que o exemplo é oportuno polo que representan os EE UU como fonte ou «laboratorio» xeográfico principal de moitas destas reflexións sobre a transformación contemporánea da paisaxe e do sentido de lugar.

En todo caso, para esta liña de revisión crítica sobre a que aquí quero chamar a atención, a interpretación puramente formal, visual, estética ou arquitectónica do sentido de lugar resulta equivocada, na medida en que a capacidade dos lugares para xerar identidades e un sentido de lugar positivo e intenso non depende tanto ou principalmente do continente como do contido, é dicir, da súa ocupación e das actividades que neles se realizan. Aínda que os lugares 
poden ter unha forma externa banal, artificial ou elemental, o que os converte en tales é a súa capacidade para promover interaccións e outras prácticas sociais complexas e intensas que os doten de significado.

No seu ensaio $A$ sense of place, a sense of time, o propio John Brinckerhoff Jackson, ao abordar as raíces e manifestacións do sentido de lugar na cultura norteamericana, defendía que o sentido de lugar do americano medio non depende tanto da arquitectura, da paisaxe ou dunha orde espacial determinada, nin sequera dos espazos deseñados e planificados expresamente para o lecer, o encontro ou a celebración cívica, senón que depende, sobre todo, dalgúns eventos, celebracións e rituais -cotiáns, semanais, estacionais ou anuais- que os cidadáns agardan, lembran ou comparten con outros concidadáns, e que, para efectos existenciais, importan máis que o propio lugar físico onde acontecen (Jackson, 1994, p. 157 e ss.). Noutras palabras, o que converte unha praza ou un mercado, por exemplo, nun espazo significativo para o sentido de lugar dunha comunidade local non é a estrutura arquitectónica que o alberga, senón o evento que celebra ou celebraba alí. Pois, en definitiva, sostiña Jackson, o sentido de lugar do cidadán norteamericano medio apoiase principalmente no sentido do tempo, na rutina ou recorrencia de certos eventos e celebracións especiais que lle dan continuidade, unidade e seguridade á comunidade. Unha opinión que conecta en boa medida coas propostas recentes do citado Kolb, que di que cómpre entender os lugares como places-where-we-do-something, máis que como places-where-something-is (Kolb, 2008, p. 8).

Ademais, como algúns estudosos dos espazos vinculados á mobilidade demostraron, o sentido de lugar emana de relacións prolongadas, estables ou repetidas cun lugar físico, pero tamén pode fundarse en experiencias móbiles, transitorias ou mesmo efémeras (Cresswell, 2001; e Puente, 2008). Traballos como os de Peter Merriman (2004) ou Tim Edensor (2003), referidos ao Reino Unido, ou como o de Peter Bishop (2006), sobre o outback australiano, puxeron de manifesto como mesmo as estradas e as súas paisaxes, ou noutras palabras, as paisaxes do automóbil -ás que o segundo destes autores chamou autoscapes- e os lugares asociados á condución -os driving places, en expresión do primeiro- poden actuar como canles polas que viaxan os usuarios duns lugares a outros, ou dunhas paisaxes a outras, e son tamén elementos integrais na construción das paisaxes e os lugares como centros significativos e de interacción social. Pero para 
comprendelos e analizalos en canto tales é preciso reconsiderar as concepcións e enfoques tradicionais sobre o sentido de lugar; cómpre desenvolver, defende Merriman, parafraseando a Nigel Thrift, un «sentido dinámico do lugar», máxime cando os lugares e o sentido de lugar son, en esencia, fenómenos cambiantes. Como ben ilustraba Relph, ao comentar as transformacións radicais experimentadas pola aldea galesa na que pasou a súa infancia (Relph, 2001, 214), as localizacións permanecen, pero os lugares cambian.

Sen perder de vista que é preciso establecer certos parámetros de calidade e de ordenación, a cultura territorial do noso tempo ten, pois, que integrar de forma equilibrada a transformación e a conservación, e iso, probablemente, non se poderá facer sen unha boa comprensión e balance do que supoñen os «non lugares» e as novas paisaxes dispersas. 


\section{BIBLIOGRAFÍA}

Augé, M.: Los «no lugares», espacios del anonimato, Barcelona, Gedisa, 1993.

BIsHop, P.: "Off-road: four-wheel drive and the sense of place», Environment and Planning D: Society and Space, vol. 14, 1996, p. 257-271.

CASEY, E.: Getting back into place: towards a renewed understanding of the place-world, Bloomington, Indiana University Press, 1993.

Consello de Europa: Recommandation 4 (1998) sur le Project de Convention Europeenne du Paysage (Quinta sesión do Congreso de Poderes Locais e Rexionais de Europa, Strasburgo, 26-28 de maio de 1998), 1998.

Cresswell, T.: «The production of mobilities», New Formations, 43, 2001, p. 4-28.

EDENSOR, T.: «M6-Junction 19-16: defamiliarizing the mundane roadscape», Space and Culture, vol. 6 (2), 2003, p. 151-168.

GARCÍA ÁlVAREZ, J.: «Nationalismes et patrimonialisation du paysage en Espagne: considerations théoriques et recherches actuelles», en I. Degrémont (ed.): Patrimonalisation des Pyrénées, entre pratiques professionnelles et pratiques scientifiques, 2008, en prensa.

JACKSON, J. B.: A sense of place, a sense of time, New Haven, Yale University Press, 1994.

KolB, D.: Sprawling places, Athens, University of Georgia Press, 2008.

Merriman, P.: «Driving places: Marc Augé, Non-Places, and the Geographies of England's M1 Motorway», Theory, Culture and Society, vol. 21, 2004, p. 141-167.

Miles, M.: «Legibility and liveability: a critique», Perspectivas Urbanas/Urban Perspectives, 5, 2004, p. 7-19.

Nogué, J.: «Nacionalismo, territorio y paisaje en Cataluña», en N. Ortega Cantero (ed.): Paisaje, memoria histórica e identidad nacional, Madrid, Universidad Autónoma de Madrid-Fundación Duques de Soria, 2005, p. 146-169.

PUENTE, P.: Espacio, lugar y experiencia. Aproximación a un debate contemporáneo, tese de doutoramento en Humanidades, Universidad Carlos III de Madrid, 2006, inédita.

PUENTE, P.: «Rethinking travel, tourism and mobility in connection with contemporary theories of place», en The Fourth Annual International Association for the Study of Environment, Space and Place Conference, Towson University (Maryland, EE UU), abril 2008, en prensa.

ReLPH, E.: Place and placelessness, London, Pion, 1976.

RELPH, E.: «Sense of place», en S. HANSON (ed.): Ten geographic ideas that changed the world, New Brunswick, Rutgers University Press, 2001, p. 205-226.

Roudié, P.: «El paisaje y los parajes del Patrimonio Mundial de la Humanidad de la UNESCO», en F. Zoido e C. Venegas (ed.): Paisaje y ordenación del territorio, Sevilla, Junta de Andalucía-Fundación Duques de Soria, 2002, p. 183-192.

VAN GORP, B. e H. RENES: «A European cultural identity? Heritage and shared histories in the European Union", Tijdschrift voor Economische en Sociale Geografie, vol. 98 (3), 2007, p. 407-415.

WaLTER, F.: Les figures paysageres de la nation. Territoire et paysage en Europe (16e-20 siecles), Paris, Éditions de l'École des Hautes Études en Sciences Sociales, 2004. 

Relatorio

\section{O PORTO E O RÍO DOURO. A CONSTRUCIÓN DUNHA NOVA RELACIÓN \\ Álvaro Domingues \\ Universidade de Porto}





\section{O RÍO DOURO: O PORTO DO PORTO}

O Porto é unha cidade indeleblemente ligada ao río Douro e mais ás historias que o tempo foi tecendo arredor desa relación.

Do longo tempo da historia chegan relatos que son habituais nas lendas fundacionais das cidades. Lonxe abondo dos perigos que viñan polo mar, a cidade foi medrando xunto a un lugar concreto onde a travesía era máis favorable. Desde o outeiro amurallado onde aínda se atopaba a catedral medieval, o burgo foi descendendo ata a «ribeira», ao longo da cal se construíron murallas que tiñan unha función militar e servían para regular o comercio. Dominio e poder, comercio e relacións son marcas recorrentes no código xenético das cidades, aquí reforzadas polas facilidades que as vías fluviais podían ofrecer cando os outros tipos de vías de comunicación eran menos eficientes e inestables. As barcas de pasaxeiros, documentadas desde a presenza romana, crearían a relación Norte-Sur. O trazado Leste-Oeste do río Douro permitía a conexión coas terras do interior, polo que se completarían así as relacións entre as cidades.

A outra escala, a conexión co Atlántico tamén sería unha porta, máis ampla, para a xeografía das «economías globais» que se foron expandindo a lugares e mercados diversos ata o de agora.

Este é o tipo de feitos dos que os historiadores dan conta e que documentan abundantemente mesmo antes da fundación de Portugal -portus cale-, cuxo nome ten a súa orixe na cidade do Porto. O territorio da conca do Douro está cheo de testemuños de presenzas culturais mesturadas -desde os gravados paleolíticos do Côa ata o santuario rupestre de Panoias (Vila Real) e a invasión e fusión de romanos, suevos (século V), visigodos ou musulmáns (séculos VIII-XI). Desde mediados do XII, xa nun período de maior seguridade, os monxes do Císter aumentaron a súa influencia sobre o territorio, labrando terras, plantando viñas e aproveitando as condicións climáticas cruzadas do Atlántico e do 
Mediterráneo. Esta prosperidade permitiu a relación entre a rexión do Douro e o Porto, e mesmo a incorporación ás rutas comerciais hanseáticas con Flandres e o Norte de Europa, á «economía global» daquela época. O viño aparece desde moi cedo como un dos principais produtos das transaccións comerciais, así como o sumagre, unha planta importante para a industria dos curtidos.

Nos séculos XIV e XV, coa participación do Reino de Portugal na conquista do Norte de África e na empresa dos Descubrimentos, o Porto afirmou o seu perfil de cidade de navegantes e mercadores, e desenvolveuse ao longo da marxe dereita do Douro, onde se atopaban os estaleiros navais e se levaban a cabo as actividades mercantís.

No século XVIII, a fundación da Compañía Xeral da Agricultura das Viñas do Alto Douro (1756-1834) consolidou a importancia nacional e internacional da cidade, a súa relación co territorio interior -o Alto Douro- e mais o seu papel mediador nas relacións internacionais. $\mathrm{O}$ monopolio do comercio do viño do Porto acelerou a ocupación da marxe esquerda do río, Vila Nova de Gaia, que foi transformada progresivamente en almacén de viño e peza fundacional dunha cidade de dúas marxes que desde aquela se foi fortalecendo. A Xunta de Obras Públicas (1763-1833) elaborou un ambicioso plan de reestruturación da cidade medieval e regulou a expansión fóra dos muros, o que incluíu un conxunto de grandes obras de construción de novas infraestruturas portuarias.

A partir do século XVI, a viticultura de calidade destinada ao comercio adquire unha crecente importancia na zona dos viños de Lamego, designación que abrangue os viños de calidade diferenciada de boa parte do actual Baixo Corgo, pero tamén noutras áreas que no século XVIII formarán parte da rexión demarcada do Douro, como as ladeiras dos ríos Távora e Pinhão.

A expansión vitícola continuou no século XVII, paralela aos cambios producidos na tecnoloxía de produción de viños e á maior penetración nos mercados europeos de viños. En 1675, aparece por primeira vez unha referencia documental á designación «vinho do Porto», relacionada co viño exportado aos Países Baixos. Por esa época iníciase un importante intercambio comercial con Inglaterra, favorecido polas guerras entre este país e Francia. Enseguida, o «vinho do Porto» domina o mercado vinícola inglés, superando os viños franceses, españois e italianos, de xeito que algúns autores británicos o consideraron «the englishmen's wine». En 1703, o Tratado de Methuen, reali- 
zado entre Portugal e Gran Bretaña, confirmou no ámbito diplomático ese intercambio comercial ao concederlles dereitos preferentes aos viños portugueses. Ao longo do século XVIII, os viños xenerosos do Douro vólvense dependentes do mercado inglés, o que se traduce nunha adaptación do produto ao gusto deste mercado destinatario e, asemade, nun crecente dominio do comercio do viño do Porto por parte de mercadores británicos que establecen a súa residencia no Porto. En 1727, a próspera colonia inglesa do Porto abre nesta cidade unha fábrica, que desempeña un papel importante na salvagarda dos intereses británicos relacionados co comercio do viño.

$\mathrm{O}$ conflito entre estes intereses comerciais e os dos produtores do Douro, progresivamente sometidos aos prezos cada vez máis baixos impostos polo comercio e, por outra banda, as esixencias de tipos de viños máis fortes, tintos, doces e augardentosos, levou a que o Estado interviñese para regulamentar a produción e o comercio dun produto clave para a economía portuguesa. Mediante a licenza rexia do 10 de setembro de 1756, instituíuse, para estes efectos, a Compañía Xeral da Agricultura das Viñas do Alto Douro, que promoveu así un vasto marco lexislativo. Entre outras cousas, procedeuse á demarcación da rexión produtora, a primeira dunha zona de denominación de orixe regulada do mundo no sentido contemporáneo da expresión.

De feito, a primeira demarcación, ordenada en 1756 e levada a cabo sobre o terreo entre 1757 e 1761, é xa unha manifestación de modernidade inequívoca, posto que, ademais da definición de límites dunha rexión vitícola, inclúe a elaboración dun catastro e dunha clasificación das parcelas e dos viños respectivos, tendo en conta a complexidade do espazo rexional, e, por outro lado, a creación de mecanismos institucionais de control e certificación do produto ao abeiro dun amplísimo fundamento lexislativo. Non é menos importante o sentido de continuidade temporal que asocia a identidade rexional coa idea de rexión vitícola demarcada, desde o século XVIII ata os nosos días, independentemente das modificacións da zona -que pasou de preto de 40000 a 250000 hectáreas- e dos límites rexionais, da dimensión do viñedo, das prácticas vitícolas ou da organización institucional do sector. As sucesivas delimitacións da Rexión Demarcada (1757-1761, 1788-1793, 1907-1908, 1921) reflicten, esencialmente, as vicisitudes da propia evolución técnica da produción, do transporte e da comercialización, pero manteñen unha forte continuidade no tocante aos principios que as orientaron e que tiveron, tanto na mentalidade popular como na das elites, unha forte carga simbólica, constituíndo así un elemento clave da identidade rexional. A identificación do territorio do Alto Douro como «país viñateiro» ou «rexión do viño do Porto» confi- 
gurou, desde o século XVIII, unha vocación económica e unha cultura específica e consolidou o sistema de relacións entre o Porto e o hinterland duriense. Desde aquela e ata o día de hoxe, as vicisitudes da vitivinicultura e do comercio de viños do Porto practicamente dominaron a historia rexional. (Candidatura do Porto a Patrimonio da Humanidade, UNESCO, 1996).

Ata o século XIX e a chegada do ferrocarril, as vías fluviais tiveron unha importancia fundamental. Ao longo do curso interior do Douro, os barcos rabelos ${ }^{1}$ facían a ruta dos viños do Alto Douro. Do Porto, por mar, partían os navíos para pescar nos bancos de Terra Nova e para o comercio e o transporte de pasaxeiros a Lisboa, África e Brasil. Para traxectos máis curtos, a navegación no río Douro tamén se empregaba intensamente para abastecer acotío a cidade con leña, carbón e unha morea de produtos alimentarios e bens de consumo corrente.

A construción da Alfándega Nova ( $c a$. 1860), cun acceso en forma de túnel que conectaba coa rede do ferrocarril, supón unha das maiores obras de artificialización das marxes, ao tempo que as fábricas se van instalando desde $\mathrm{O}$ Freixo ata Massarelos e Lordelo, especialmente xunto ás marxes onde desaugan pequenos ríos e onde as características topográficas son máis favorables.

Así, a relación da cidade co río experimenta un forte pulo e a segunda metade do século XIX é unha época de desenvolvemento lonxitudinal da cidade polas súas marxes e, nas cotas máis altas, de expansión en forma de «dedos» ao longo das principais estradas que unían o Porto co Norte e Nascente. A revolución dos transportes tamén propicia a construción de dúas pontes de ferro: Maria Pia (1877), de Gustave Eiffel, para o paso do ferrocarril, e a ponte Luís I (1886), con dous taboleiros, un inferior situado no mesmo lugar onde sempre se fixo a travesía principal do Douro, e un superior que creaba unha nova conexión para a cidade, que xa medraba afastada da relación directa co Douro. As enormes obras do terraplén e do novo edificio da Alfándega lévanse a cabo practicamente na mesma época en que xa se estuda a posibilidade de trasladar o porto comercial a Leixões, na parte norte do Porto e na desembocadura do río Leça.

Xunto á desembocadura do río, preto do forte que vixiaba a barra e do faro, construíuse un paseo público con fontes, palmeiras e xardíns, expresión dun

\footnotetext{
${ }^{1}$ Embarcación típica do río Douro que ten un remo longo e groso como temón.
} 
certo gusto burgués e cosmopolita que apreciaba o olor a mar, as bandas no quiosco, o tenis, o parasol e o cortexo discreto.

Ata os anos sesenta, próximos á revolución do automóbil, que en Portugal foi tardía e que daría lugar á construción dunha nova ponte de cemento -a Arrábida, en 1963, neste caso só con taboleiro superior-, as marxes do Douro seguen a ter pouca presenza residencial e conservan vellos edificios de almacéns e fábricas e unha ruta ribeirá que facía o tranvía desde A Ribeira ata a nova zona portuaria e industrial de Leixões e Matosinhos. Da modernización do gas e da luz eléctrica quedaron tamén á beira da auga o tanque de gas e as estacións transformadoras de electricidade.

Unha vez pasada a desembocadura e fronte ao mar, medraba outra cidade de chalés de veraneo e de residencia distinguida das clases acomodadas. Cara ao lado do río da ponte D. Luís quedaban algunhas grandes casas nos lugares da costa onde a escarpa granítica era menos abrupta. No Freixo, un pazo barroco resistía na súa «segunda vida» como residencia dun industrial de moendas, testemuñando o paso dunha aristocracia arruinada aos novos industriais e comerciantes emerxentes. Con todo, as principais marcas do Porto industrial xa non se producían unicamente na beira do río, senón tamén na cidade alta, xunto á estación do ferrocarril, nas afastadas zonas residenciais de obreiros e, sobre todo, en rexións rurais como Vale do Ave e Vale do Vizela, onde a industrialización se produciu nos campos, malia que a riqueza moitas veces se canalizaba cara ao Porto -o actual Museo de Serralves era unha casa de campo e un terreo dun rico industrial do sector téxtil do río Vizela. Así, a nova burguesía industrial acabou por mesturarse coa vella burguesía dos terreos do Douro, da produción do viño do Porto e do comercio con Inglaterra e Brasil.

Houbo que agardar ata preto dos anos noventa do século XX para que se materializase unha transformación que seguiu a intensificarse ata hoxe. Pero o tempo pasou no Porto e nas marxes do Douro sen grandes sobresaltos deses que, como os grandes incendios, terremotos ou guerras devastadoras, borran a memoria das cidades. As marxes do Douro son un pergamiño onde aínda se rexistran as sucesivas pegadas e se acumulan marcas do longo tempo e dos períodos breves nos que os cambios se producen rapidamente. O mesmo terraplén da Alfándega Nova, unha das maiores obras de transformación das marxes, deixou do lado oposto ao río a pegada do antigo nivel da praia, dos arcos de pedra que 
defendían as vivendas altas de Miragaia dos grandes asolagamentos que o río traía no inverno.

En 1985, concluíuse o encoro de Crestuma-Lever, a última das grandes presas do Douro, peza importante no sistema de produción hidroeléctrica do río, no control das enchentes e na navegación que agora se pode facer, aínda que de forma moi limitada, ata a fronteira con España.

\section{SEGUNDA ANDADURA: A CONSTRUCIÓN DUNHA NOVA RELACIÓN}

Hoxe, cando se fala do río Douro, trátanse principalmente catro temas:

É unha vía fluvial, na que se intercalan encoros, esclusas e albufeiras, de comunicación co Alto Douro usada polos barcos turísticos, cunha conexión cada vez maior coa rexión viñateira, onde se combina o negocio do viño co turismo. As expectativas de uso do río para o transporte de mercancías limítanse, polo de agora, a algún transporte de granito, aínda que hai depositadas certas esperanzas nas obras dos novos peiraos da desembocadura do río, que permitirán o paso de embarcacións ao mar e ao porto de Leixões. Os custos da intermodalidade transporte fluvial-transporte non fluvial impiden o uso dos barcos de mercancías. O principal potencial de xeración de cargas, o viño, non ten relevancia ningunha. A preparación e embotellamento do viño do Porto realízanse cada vez máis na rexión orixinaria, unha vez extinta a obrigatoriedade de uso do almacén de Vila Nova de Gaia, onde, polo demais, o ferrocarril xa substituíra o transporte por barco. A ambición de crear un corredor de transporte de mercancías a España aínda non suscita interese. O Instituto Portuario e de Transportes Marítimos Douro continúa coa súa misión de garantir a canle navegable -sobre todo ata A Régua, a uns 100 quilómetros do Porto, para os barcos de mercancías de ata $80 \mathrm{x} 12$ metros- e xestionar as obras dos novos peiraos na desembocadura ${ }^{2}$. No entanto, as embarcacións que utilizan o Douro son sobre todo as turísticas.

En segundo lugar, a relación co Alto Douro Viñateiro, co Parque Arqueolóxico do Val do Côa -ambos os dous declarados Patrimonio da Humanidade pola UNESCO- e co Parque Natural do Douro Internacional. A singularidade dos valores culturais e paisaxísticos segue a ter un elevado potencial turístico e de con-

${ }^{2}$ Cfr. http://www.douro.iptm.pt/PT/via_navegavel/. 
servación da natureza, malia que a demanda turística, agás no Douro Viñateiro, continúe a ser moi escasa e pouco importante na rexión Norte Interior de Portugal. Esta rexión está a experimentar un acelerado proceso de despoboamento e de «desruralización», exceptuando o dinamismo do sector viñateiro.

O terceiro tema é a forte presión exercida polo turismo nas marxes do Douro Litoral, próximo á aglomeración metropolitana do Porto, para a execución de determinados proxectos de turismo residencial. Este tipo de investimentos comportan un impacto paisaxístico e unha deterioración considerables, o que supuxo moitas dificultades para a concesión de licenzas a pesar dos postos de traballo que isto poida crear.

Por último, no Porto e en Vila Nova de Gaia, no treito final do Douro, asístese a unha rápida transformación que pasaremos a abordar a continuación.

\section{Turismo, estetización, patrimonio e sostibilidade}

O río Douro pasou de ser un «río de mal navegar» a constituír un elemento e unha experiencia estéticos, un recurso de produción do imaxinario onde interveñen todos os traumas de perdas sucesivas: da cidade histórica, vella e disfuncional, que precisa con urxencia a súa preservación e patrimonialización, e que é obxecto de formas de apropiación «superficiais», "pasteurizadas», «mercantilizadas», reducidas a escenarios e novos encantamentos para os que a memoria do pasado se sintetiza nun enfoque pintoresco. Das paisaxes, baleiradas da sociedade e da economía rural tradicional e da historia; tornadas disfuncionais pola perda dos «xardineiros da paisaxe» que creaban vínculos e formas de entender a transformación e a apropiación do territorio, as paisaxes transfórmase nun papel pintado, recurso inesgotable de emocións e experiencias inesquecibles, asemade fóra e dentro da xeografía e da historia. Da «natureza», do «medio natural», compensado polo discurso apazugador da sostibilidade e da ética asociada ás prácticas non depredadoras de recursos «naturais».

Noticia sobre o novo peirao de Gaia:

Despois de moitas décadas ao servizo da actividade portuaria de mercancías, o proxecto Peirao de Gaia inclúese no plan de renovación e valorización de toda a zona ribeirá de 
Gaia, que o converterá nun espazo de recreo e lecer rodeado dunha paisaxe urbanística inigualable. O Peirao de Gaia abrangue amplos espazos comerciais, de restauración e servizos dunha elevada calidade arquitectónica caracterizada polo emprego de materiais que resaltan a lixeireza e transparencia das fachadas. A expresión plástica dos edificios está baseada nunha estrutura de dous andares, cuxas cubertas inclinadas crean o xogo dinámico das siluetas características dos almacéns das adegas do viño do Porto. Desde todo o Peirao de Gaia e, sobre todo, desde as explanadas dos andares superiores, gózanse inesquecibles vistas do Douro e da paisaxe patrimonio mundial da ribeira do Porto. O Peirao de Gaia conta cunha praza exterior, a xeito de anfiteatro, concibida como espazo polivalente de entretemento, denominada Praza Super Bock, e coa praza central.

Eventos e celebracións no Peirao: Feira de artesanía e antigüidades (Art\&Guidades); última fin de semana de cada mes; Fin de Ano; Día dos Namorados; Entroido; 25 de abril; Aniversario do Peirao; San Xoán; Concertos; Exposicións; Espectáculos na rúa; Pista de xeo; Lanzamento de neve artificial. O renovado Peirao de Gaia é un núcleo de vivencias que acompaña os cambios e os desexos dunha poboación en permanente evolución (www.juventude.gaiaglobal.pt).

\section{Noticia sobre unha iniciativa turística emprendedora no Douro Viñateiro:}

Aquapura Douro Valley é un refuxio único e requintado situado na marxe sur do río Douro, entre os viñedos declarados patrimonio mundial pola UNESCO, fronte á cidade de Peso da Régua. Vale Abraão, unha propiedade histórica e cultural asociada á produción dos famosos viños da rexión, foi recuperada e convertida nun hotel que ofrece corenta e un cuartos e nove suites con diferentes estilos e vistas, incluída unha Suite Presidencial. Diversos xardíns e unha abraiante vexetación rodean a propiedade. Tamén hai dispoñibles catorce casas con piscina e terraza privada situadas fronte ao río, de estilo moderno, e outras sete dun estilo máis tradicional entre as viñas. As áreas comúns do hotel, espazosas e confortables, transmiten luxo e relaxamento en toda a propiedade e, asemade, fan perder a noción do tempo e do espazo. Nun ambiente en que se fusionan a filosofía asiática e a cultura europea, aparece un spa de referencia internacional. Neste espazo de $2200 \mathrm{~m}^{2}$ instaláronse desde un laconium ou unha sauna panorámica ata dez salas de tratamento con luz natural e produtos especialmente fabricados por marcas de prestixio internacional (Karin Herzog e Ytsara). O emprego de ingredientes locais, cun toque da cociña internacional, permítenlle a Aquapura ofrecer experiencias gastronómi- 
cas para todos os sentidos. Tamén hai dous bares, unha piscina exterior climatizada, un campo de tenis e unha fraga protexida de cinco hectáreas (http://lisbon.nethotels. com/nethotels/portuguese/hotels/aquapura_douro_valley).

Esta encrucillada foi o escenario de boa parte do que aconteceu ao longo do río Douro durante as tres últimas décadas, quer nas frontes urbanas do Porto e de Vila Nova de Gaia, quer na rexión do Alto Douro Viñateiro.

No Alto Douro Viñateiro, o cambio máis visible é o da expansión do plantío da viña -o viño do Porto e viños de mesa- e un incremento continuo do investimento en proxectos turísticos, aproveitando os recursos paisaxísticos e culturais, a distinción da declaración da UNESCO -Alto Douro Viñateiro e Parque Arqueolóxico do Côa- e a clasificación do Parque Natural do Douro Internacional. A internacionalización e concentración empresarial da industria do viño prodúcense paralelamente ao proceso de «desruralización» da rexión situada fóra da área viñateira. Nesta, a poboación vai descendendo e envellecendo, e abandona as vellas prácticas de traballo agrícola da terra e de conservación e creación de paisaxe.

No Porto, antes da revolución democrática de abril de 1974, iniciárase unha operación de melloras e saneamento dos barrios pobres da Ribeira/ Barredo, o que incluía o traslado dos residentes a novos barrios, dándose así comezo á intervención nos espazos e infraestruturas públicos. Xa no Portugal democrático, a Ribeira/Barredo foi obxecto dunha iniciativa de intervención profunda nos edificios e de dotación de servizos de proximidade. Tras estas operacións coordinadas por un Comisariado de Renovación Urbana CRAUB, o centro histórico do Porto é declarado Patrimonio da Humanidade en 1996. Ese mesmo ano, o Goberno, a Administración portuaria e o Concello do Porto asinan un convenio de colaboración para a recualificación das marxes do Douro situadas entre A Ribeira, Massarelos e a desembocadura do río, que incluía unha intervención nun antigo pazo de veraneo do século XVIII, o Pazo do Freixo, posteriormente transformado en residencia dun industrial de moendas no século XIX. Por outra banda, o edificio da Alfándega Nova e a zona circundante foron rehabilitados para a celebración do VIII Cumio Iberoamericano de 1998 e despois convertidos no novo Museo dos Transportes e das Comunicacións. 
Nos proxectos de renovación urbana do Porto 2001, Capital Europea da Cultura, a ribeira é obxecto dunha profunda intervención, desde Massarelos ata a desembocadura -infraestruturas, canle do tranvía, xardíns e espazos públicos, viaduto do Peirao das Pedras. O paseo ribeirán adquire así outra visibilidade e distinción, o que permite que os investimentos sexan cada vez máis intensos no sector inmobiliario residencial. A intervención nas marxes ribeirás, no centro histórico e na zona central da cidade están agora a cargo dunha Sociedade de Rehabilitación Urbana (2004), unha entidade pública financiada nun 60\% polo Instituto Nacional da Vivenda e nun 40\% polo Concello do Porto.

$\mathrm{Na}$ ribeira de Vila Nova de Gaia, a Administración Portuaria APDL, o Concello e entidades privadas estableceron tamén os primeiros contactos para executaren un proxecto de grande envergadura no peirao de Gaia -neste momento baleiro-, nas marxes do almacén viñateiro e no paseo público que vai ata a desembocadura do río -actual zona de intervención do programa POLIS. Alén da cualificación do espazo público, realízase tamén unha profunda renovación infraestrutural no ámbito do saneamento do río Douro - na ribeira do Porto construíronse dúas estacións de tratamento de augas residuais. O POLIS de Gaia é un proxecto ambicioso que mobiliza capitais privados e grandes reservas de fondos de antigas parcelas, conventos, fábricas, almacéns, peiraos, un antigo secadoiro de bacallau, dársena, hoteis, etc., e que consiste nunha intervención profunda na aglomeración e porto pesqueiro da Afurada e no redeseño íntegro da marxe e dalgunhas vías de acceso ás zonas altas da ribeira do Douro. Parte deste proxecto urbanístico é agora xestionado por PARQUE EXPO, unha empresa nacida durante a grande operación urbanística do parque de exposicións da EXPO 98 de Lisboa e que levou a cabo en Portugal o primeiro proxecto ao estilo internacional das waterfronts asociadas á organización de grandes eventos.

\section{CONCLUSIÓN}

Xa están botadas as cartas para o futuro próximo. O río Douro perdeu a súa lóxica tradicional: xa non é o porto do Porto. Xa non é unha vía ao servizo das operacións mercantís; foi domesticado encoro tras encoro e agora é un dos prin- 
cipais produtores de enerxía hidroeléctrica do país ao longo dos seus case 300 quilómetros de percorrido por territorio portugués -incluído o Douro Internacional.

As lembranzas do pasado están agora "compactadas» en "produtos turísticos», desde os gravados neolíticos do Côa ata os aparellos portuarios, almacéns e fábricas dos séculos XIX e XX. A patrimonialización do Porto e da rexión viñateira amplían un imaxinario infinitamente reproducido en imaxes e textos para turistas, simplificando, eliminando a complexidade dos significados e reducíndoos a versións preparadas para consumir: cosmopolitismo e localismos conviven, como na gastronomía e nos viños, en forma de estrañas «reducións» -na cociña, unha redución é o proceso de espesar ou intensificar o sabor dun líquido, como unha sopa ou un mollo, mediante a evaporación- e «fusións». Certos nomes de complexos residenciais, como Douro's Place e D’Ouro Villa, ou de proxectos turísticos, como Aquapura Douro Valley, son inesperadas fusións do latín e o inglés, unha lingua máis que morta e outra sumamente viva, que designan un novo mapa e unha xeografía diferente en construción.

O río é, en primeiro lugar, un escenario, unha imaxe poderosa, unha icona, un espectáculo. A construción de novos peiraos na desembocadura do río, así como as expectativas postas no proxecto de navegabilidade, parecen polo de agora desprovistas da lectura que os operadores empresariais fan deste asunto. Semella que o río non ten un hinterland económico adecuado ao tráfico de mercancías, e mesmo isto entra tamén en conflito con posibles escenarios de modernización da liña ferroviaria, un proxecto actualmente abandonado.

Queda aínda a nova lectura que a dinámica económica fai desta cuestión. O río Douro, «as vistas sobre o Douro» son o argumento máis usado para crear valores de distinción e de penetración ascendente para promover "produtos inmobiliarios» considerados excepcionais. Inmune ás flutuacións cíclicas do mercado inmobiliario en xeral -en crise desde 1999-2000-, o ritmo de construción e de anuncio de novas promocións no Porto e en Vila Nova de Gaia parece imparable. Desde o «aburguesamento» da zona histórica e monumental ata os novos proxectos sobre terreos desocupados ou edificios industriais obsoletos, a «febre do Douro» aumenta á mesma velocidade que a filoxera na viña no século XIX. Entre o xúbilo de quen vende e quen compra, apréciase unha difícil conciliación dos intereses de defensa dos bens paisaxísticos, culturais e ambien- 
tais, por un lado, e, por outro, dos derivados do incremento desmesurado da demanda e da oferta de inmobles máis ou menos "xenéricos», destinados á gama alta do mercado e a unha certa mise-en-scène. Para todo hai respostas: as promocións son «sostibles e están inseridas na paisaxe», aínda que de natureza só teñan unha herba monótona; os estilos arquitectónicos varían entre a mestura posmoderna e un certo minimalismo e, para quen pode e o valora, levan a sinatura dun arquitecto coñecido.

Esta é a nova fórmula, unha sociedade distinta e outro tipo de ordenación do territorio que o río Douro e as súas marxes van experimentando, nun difícil equilibrio entre a defensa dos valores identitarios e dos patrimoniais que, asemade, van sendo tragados polas novas intervencións, das que se afirma que están adaptadas ou en consonancia cos devanditos valores: heterotopías no verdadeiro sentido de Michel Foucault:

Estamos na época do simultáneo, estamos na época da xustaposición, na época do próximo e do afastado, do un ao lado do outro, do disperso. Estamos nun momento en que o mundo se experimenta, coido, menos como unha gran vida que se desenvolve a través do tempo que como unha rede que une puntos e se entretece. Talvez se poida dicir que algúns dos conflitos ideolóxicos que alimentan as polémicas actuais se desenvolven entre os piadosos descendentes do tempo e os habitantes encarnizados do espazo. O estruturalismo, ou polo menos o que se agrupa baixo este nome, é o esforzo por establecer, entre elementos repartidos a través do tempo, un conxunto de relacións que os fai aparecer como xustapostos, opostos, implicados entre si, en definitiva, que os fai aparecer como unha especie de configuración; e, dita sexa a verdade, non se trata de negar o tempo, senón dunha certa maneira de tratar o que chamamos tempo e o que chamamos historia (Foucault, 1984, p. 46-49).

Esta mudanza é o que verdadeiramente nos confunde. Perdidos os nexos «funcionais» da relación do río coas súas marxes, a nova construción de sentidos e os seus diferentes significados -a heterotopía- provoca unha ruptura profunda cos modos tradicionais de facer e de xustificar as opcións e as execucións da ordenación do territorio e do urbanismo. 
O PORTO E O RÍO DOURO. A CONSTRUCIÓN DUNHA NOVA RELACIÓN

\section{BIBLIOGRAFÍA}

Foucault, M.: «Des espaces autres», Architecture, Mouvement, Continuité, n. ${ }^{o}$ 5, outubro de 1984, p. 46-49.

Nonell, A. G.: Porto 1763/1852: a construção da cidade entre despotismo e liberalismo, Faculdade de Arquitectura da Universidade do Porto, 1998, diversas edicións. 

Retruque

\section{UNHA REFLEXIÓN SOBRE O PORTO}

Julia Fernández de Caleya Blankemeyer Universidade da Coruña 

A observación do Porto desde o aire, despois da lectura do relatorio de Álvaro Domingues, deume, así e todo, unha idea bastante clara da evolución desta cidade ao longo de varios séculos.

Explícasenos a importancia de todos os centros históricos, fortalezas, edificios relixiosos e administrativos que deixaron a súa pegada como elementos que constitúen a historia da cidade e, asemade, dos espazos verdes que, ás veces, os acompañan, dando unha esponxosidade, creando un protagonismo urbano importante do «verde de detalle».

Fálasenos da importancia do viñedo e os seus viños, que na súa orixe se vincularon fortemente ás ribeiras do río polo que foron transportados, onde se concentraron os grandes almacéns e adegas que condicionaron notablemente a vida da cidade, pero tamén do comercio crecente con Inglaterra, que fixo que estes viños fosen uns dos preferidos neste país, mesmo superando os franceses, italianos e españois, o que tivo unha importancia fundamental para o Porto e o seu desenvolvemento.

A cidade do Porto, que conta con elementos paisaxísticos destacados como o río, o mar, a súa agricultura vinícola, desenvolveu as infraestruturas de apoio necesarias para comercializar por barco -portos- e posteriormente por terra -pontes- os seus produtos e aumentou así o seu crecemento económico en ambas as dúas ribeiras do Douro.

Contemplando esta cidade e o seu crecemento, vemos como aproveitou os elementos paisaxísticos dominantes, o río, o mar, a marcada topografía, e conseguiu así medrar sen que por iso perdera a conexión co verde da súa paisaxe urbana, tanto no tocante aos seus edificios emblemáticos, como ás súas viñas ou aos montes circundantes.

As prazas, os parques, os lugares emblemáticos á beira do río e a costa, pero tamén a súa distribución territorial equilibrada, reúnen todos os ingredientes para poder tecer unha trama verde vinculante entre eles. Estes eran os obxecti- 
vos do planeamento moderno iniciado por Olmstead, o primeiro arquitecto paisaxista así denominado.

A conexión da cidade e os seus distintos barrios por medio de fermosos paseos, zonas peonís e prazas fai que o Porto teña unhas posibilidades das que outras cidades carecen. Vendo as imaxes que presento, pode apreciarse unha «distribución do verde organizada» e planificada de forma equilibrada, o que lle dá ao Porto unha vantaxe que non pode desaproveitar para gañar o futuro.

A súa propia topografía xerou unha forma de utilizar eses accidentes e deulles un carácter único á unión das súas dúas ribeiras e ás súas pontes.

Nesta exposición pretendo destacar algúns exemplos comparativos de como o seguimento de determinados modelos en Europa e nos Estados Unidos teñen creado unhas cidades máis acolledoras para os seus habitantes pola proximidade que se lles brinda para ter un acceso fácil ás zonas verdes, aos seus espazos públicos e aos seus diversos parques históricos.

O Porto, que se desenvolveu cunha distribución moi ben equilibrada dos espazos verdes, brinda as posibilidades de vincular estes lugares entre si, favorecendo o crecemento futuro e a súa paisaxe urbana. Un bo expoñente sería París e o modo en que logrou unir os parques e as zonas históricas emblemáticas, como o Bois de Bologne a través dos Campos Elíseos coas Tullerías, por medio do bulevar.

Os exemplos traídos están baseados en modelos como o dos Greenbelts de Howard nos seus New Towns, que poden verse na imaxe do gran Londres transversal, onde o cidadán pode camiñar seguindo pautas non afastadas dos espazos verdes. Outro exemplo sería Viena co Ring.

O Porto, a través das imaxes aéreas, transmite a mesma sensación de que se poden realizar percorridos peonís, como no caso de Essen, que lle permitan completar o abano de posibilidades para crear vínculos entre as súas partes cunha boa trama plantada.

Outro exemplo pode ser a cidade de Oslo, onde vemos a importancia da xeografía, o río, as pendentes, como a causa orixinaria da súa trama verde.

O Porto débelle á accidentada topografía a súa forma e o seu carácter persoal, coas espectaculares pontes. As marxes verdes do río confirman a adecuación da súa presenza ao lugar, como acontece no parque fluvial de Iugoslavia.

Con estes argumentos pode apreciarse no Porto un desenvolvemento harmónico, que lle permitiu resolver os problemas, quizais de forma intuitiva pero 
sen dúbida intelixente, sen hipotecar o seu futuro e sen destruír a cidade e conservando as posibilidades de combinar o seu deseño coa modernidade que lle traen outras industrias necesarias como son as novas tecnoloxías, o turismo, etc., ás que non pode nin debe renunciar.

Seguindo os mesmos modelos que observamos no Ruhr, vemos como as industrias, a vivenda, a historia ou a cultura poden apoiarse nas súas formas territoriais para salvagardar a natureza nos puntos máis sensibles, entrelazándose unhas coas outras; é a zona de maior poboación de Alemaña e así e todo non se nota. Nas súas valgadas ou lugares de cultivo, sitúan os bosques e crean os espazos verdes demandados pola poboación circundante.

Penso que é importante aprender destes bos exemplos da nosa cultura europea, na que moitos medramos e onde uns influímos nos outros, para que, sen perder a identidade, poidamos mellorar o que temos sen arruinalo, vendo como resolveron os problemas da industrialización cando alí se lles presentaron. O obxectivo é lograr que o benestar e o progreso continúen, pero sen arruinar o noso medio natural, tan vulnerable, porque del vivimos e nos alimentamos a maioría de nós. 

Relatorio

\section{ACEPTARON AS SOCIEDADES RURAIS EUROPEAS AS POLÍTICAS PAISAXÍSTICAS PÚBLICAS?}

Pierre Donadieu

École Nationale Supérieure du Paysage de Versailles 

Neste texto pretendo amosar que a produción social e política das paisaxes rurais, no sentido xeográfico da expresión, depende da interacción de dúas forzas: a das invitacións e os requirimentos públicos nacionais ou europeos, segundo os cales cómpre facer uso da noción de paisaxe para construír marcos vitais considerados bens comúns ou públicos, no sentido en que empregan estes termos os economistas; e a dos proxectos e intereses individuais e colectivos dos actores locais, en especial os agrícolas, que teñen como fin producir unha paisaxe en tanto que única consecuencia da influencia económica e territorial que exercen sobre o espazo.

No primeiro caso, existe a promesa de produción dun espazo multifuncional, provisto de valores materiais e inmateriais e percibido como un ben común paisaxístico que se debe transmitir; no segundo, a produción dun territorio agrícola que, en xeral, ten un carácter monofuncional e exclúe os valores non económicos externalizados como biodiversidade, memoria, identidade, beleza, benestar, etc.

As sociedades «rurbanas», que hoxe apenas son de índole agraria, estrutúranse arredor da idea dos bens comúns da paisaxe rural, no primeiro caso, e arredor dun ideal de territorio agrícola que constitúa a base da mera produción de mercadorías, no segundo.

\section{O PROXECTO PAISAXÍSTICO: UNHA REACCIÓN PÚBLICA DIANTE DA RUPTURA DAS PAISAXES RURAIS?}

O proxecto paisaxístico constitúe unha invitación lene ou firme -requirimento- contida nos textos xurídicos -lexislación nacional e convenios internacionais- a facer uso da noción de paisaxe para dotar dun marco regulamentario a produción social e política do espazo. Ata mediados do século XX, en Europa, estas normas designaban, sobre todo, localizacións que debían ser obxecto de 
protección por teren uns valores relacionados coa identidade nacional -os sitios históricos, por exemplo- e, máis raramente, valores naturais -os parques e reservas naturais nacionais ${ }^{1}$.

En 1972, a Convención do Patrimonio Mundial da UNESCO ampliou a escala planetaria a preocupación pola protección das paisaxes notables de tipo cultural e natural. Posteriormente, a Convención Europea da Paisaxe (Florencia, 2000) redefiniu a noción de paisaxe alén do seu ámbito habitual, o das políticas de protección. Para os países que ratificaron esta convención, a paisaxe, como "percepción que teñen as poboacións dunha parte do territorio, cuxo carácter resulta da interacción de factores naturais e/ou humanos», tornouse unha ferramenta de produción social e política de espazos, sendo estes o marco e a base da vida diaria humana e non humana ${ }^{2}$.

Tal ampliación de óptica reviste unha importancia considerable para os países europeos que ratificaron esta última convención. Significa que a idea que cadaquén ten do benestar humano -o propio e o dos semellantes- e do non humano -a vida animal e a vexetal- debe pórse en relación cos caracteres físicos; é dicir, cos atributos perceptibles das contornas en que se desenvolven os seres vivos. Esta nova óptica paisaxística significa, así mesmo, que aqueles que adopten estes principios se adhiren á idea da construción da identidade das paisaxes europeas así producidas. A convención, que emana do Consello de Europa, non di que paisaxes se deben producir, senón como producilas facendo referencia ás calidades e aos valores paisaxísticos que os europeos, sexan individuos ou grupos sociais, designen para estes efectos.

Tal proxecto concírnelles a todas as sociedades rurais das nacións e rexións europeas. Estas últimas víronse afectadas por transformacións das súas paisaxes que foron percibidas de diversos modos segundo os países e as épocas.

\section{As rupturas paisaxísticas rurais}

Unha ruptura paisaxística é unha modificación das paisaxes que lles afecta a aqueles que a perciben. Pode ser brusca, como a desaparición, da noite para a

\footnotetext{
${ }^{1}$ Véxase Donadieu e Scazzosi (Donadieu e Périgord, cap. 3, 2007).

${ }^{2}$ Enténdese por isto que os obxectivos de conservación, restauración e creación de paisaxes lles concirnen tanto ás sociedades humanas como ás poboacións vexetais e animais.
} 
mañá, dunha plantación forestal destruída por un trebón; rápida, como a inducida pola construción dunha liña ferroviaria ou unha autoestrada; ou moi lenta, a semellanza do que ocorre coa penetración urbana no campo, a transformación dun porto pesqueiro en porto de recreo ou a extensión de plantacións forestais polas montañas.

Esta ruptura, que deron por boa, por exemplo, os agricultores progresistas do decenio de 1950, era desexada polos técnicos agrícolas do Estado francés. Tales mudanzas radicais, consideradas destrutivas polos cidadáns que posteriormente repoboaron o espazo periurbano e rural, foron deploradas, e os poderes públicos, iluminados polos expertos, tentaron remediar logo esta situación mediante políticas públicas de conservación e restauración a partir do decenio de 1970 . Nunha época posterior, a Política Agrícola Común pretendeu, desde a década de 1990, atenuar os efectos que ten sobre a paisaxe e o medio natural.

As causas das rupturas lentas deben procurarse nas evolucións demográficas e económicas que aconteceron ao longo do século pasado. Os éxodos rurais cara ás cidades e colonias dos países europeos baleiraron o campo e a montaña da maioría dos seus agricultores e artesáns. Nas rexións de montaña, a diminución da actividade agraria é visible hoxe no abandono da meirande parte das terrazas agrícolas e na diseminación, ás veces masiva, de plantacións naturais e artificiais de coníferas e frondosas. Tanto na periferia das cidades pequenas como na das metrópoles, a periurbanización controlada -Alemaña, Gran Bretaña, Países Baixos- ou máis libre -sur de Francia, Italia, Grecia- fíxose a expensas dos espazos agrícolas e dos agricultores. Por outra banda, a mecanicación permitiu que por todas as partes se intensificase a produción agrícola, o que comportou consecuencias paisaxísticas xulgadas como lamentables polos «rurbanos» ${ }^{3}$-concentracións parcelarias, desaparición de sebes e do pequeno patrimonio rural- e tamén consecuencias ambientais - polución das augas, regresión da biodiversidade.

A toma de conciencia dos efectos nefastos das políticas agrícolas produciuse grazas á información difundida polos medios de comunicación, xa que permitiu que todo o mundo comprendese o sentido da ruptura paisaxística, tanto máis na medida en que a sociedade rural se tornaba máis urbana e menos agrícola ou

\footnotetext{
${ }^{3}$ Os «rurbanos» son habitantes permanentes ou temporais do campo, que teñen unha actividade ou un emprego na cidade. Son asemade rurais, pola súa localización, e urbanos, polas súas actividades e a súa cultura.
} 
agraria; isto desembocou -ou está a desembocar, nos últimos países europeos que seguiron esta evolución, como Portugal- nunha situación paradoxal:

Por unha banda, unha maioría da poboación cidadá que vive no campo, traballa na cidade do lado -commuters- e desexa manter un estilo de vida san, agradable, equipado e accesible; pola outra, os empresarios agrícolas, preocupados por obter unha rendibilidade económica e remisos a aplicar as normas ambientais e paisaxísticas que poidan poñelos nunha situación de desvantaxe con respecto á competencia.

Ademais, por unha parte están tamén as persoas que posúen unha segunda vivenda no campo e os turistas que van á procura dunha ruralidade mítica, de identidades paisaxísticas desaparecidas ou confinadas en reservas, e dun fácil acceso ao campo; pola outra, os agricultores, horticultores e gandeiros, que diversifican a súa produción e recorren ao pluriemprego, mais que non poden decidirse a vivir máis da prestación de servizos agrícolas á colectividade -especialmente servizos de tipo paisaxístico e ambiental- que da venda dos seus produtos.

Por que tal contradición? É que xa non lles resulta posible aos habitantes e ás poboacións que circulan polo campo percibir as paisaxes rurais tal e como se producen, e non tal e como as soñan ou como lles prometen as axencias turísticas e os medios de comunicación? Todo depende de como consideren o mundo rural e das «lentes paisaxísticas» que filtren a súa percepción.

\section{Catro maneiras de percibir as paisaxes rurais}

A primeira é herdeira da historia da pintura paisaxística e do nacemento do turismo, e presenta a paisaxe en tanto que imaxe dotada ou non de atributos estéticos, como propoñen os cadros ou as fotografías para admiración de quen segue as descricións pintorescas das guías turísticas. Así xorden escenas nostálxicas de granxas vellas, gandos apracibles, carreiros campestres e avesíos, antigos cruceiros, castelos de outrora, regatos calmos que inspiran o paseante do campo. Estas visións procuran a imaxe "escénica", atractiva e fascinante. Nacidas nos museos, do contacto coas obras pictóricas e as fotografías nostálxicas, son externas ao país agrario, non reteñen del máis que a superficie -brillante ou deslucida- e denuncian a perda de memoria visible do campo. Tales olladas non son innatas: están «formadas» pola cultura das imaxes que circulan polo mundo dos 
medios e nelas fundaméntase unha parte dos mercados turístico e residencial. A súa tendencia é a de esperar que o campo se torne un inmenso parque público que sexa fonte de emocións estéticas e de sensacións de benestar; un punto no cal quen así o agarda adoita ficar decepcionado, xa que o campo agrícola non está concibido para se converter nun parque de atraccións.

A segunda categoría de percepcións refírese ás visións «informadas» pola influencia das ciencias, as artes e a erudición dos guías turísticos, que fan que se interpreten as paisaxes rurais a través da sapiencia dos historiadores, xeógrafos e arqueólogos, xeólogos, botánicos ou ornitólogos, agrónomos, etnólogos e sociólogos, arquitectos e urbanistas. Tantos coñecementos que levan a comprender o que se investiga e se ve, que sinalan os desafíos económicos, ambientais, sociais e culturais da evolución das paisaxes... Cómpre dicir que os turistas atraídos por estas visións teñen máis relación co turismo cultural e co ecoturismo. A estes viaxeiros curiosos preocúpalles persoalmente a orixe do que perciben, o que non exclúe que vaian á procura de espectáculos fascinantes. Desexan comprender o funcionamento dunha reserva natural ou dunha marisma salina, a arquitectura dunha capela ou a orixe dunha localización arqueolóxica. O campo constitúe para eles un mundo perceptible de signos que cómpre descifrar, cuxas formas agrícolas quedan ás veces no esquecemento.

Ao contrario do que acontece coas dúas categorías precedentes de visións, externas ás terras que se atravesan, a terceira óptica élles interna. Trátase das percepcións visuais dos produtores de paisaxes rurais: enxeñeiros forestais, agricultores, gandeiros ou horticultores, mais tamén profesionais do litoral, como os dedicados ao cultivo de moluscos. Por naceren no propio lugar, están vinculadas aos territorios de cada produtor: os campos ao dono dunha explotación agrícola, a plantación ao silvicultor, os invernadoiros ao horticultor, mais tamén os medios naturais ao naturalista, as estradas ao enxeñeiro e mesmo os carreiros ao paseante ou as pistas ao xinete. Estas percepcións son as dos «iniciados» á vida local, coa que normalmente están familiarizados. Adoita tratarse de habitantes permanentes, mais, se son residentes secundarios, a súa visión híbrida toma prestados diversos elementos, segundo a duración e a intensidade da súa ancoraxe local, das visións formadas ou das informadas. Ás veces, algúns turistas, na procura da autenticidade das paisaxes rurais, buscan a compaña de grandes coñecedores das rexións agrícolas ou vitícolas. 
A última categoría, a dos «corpos iniciados», constitúe unha extensión da anterior, que pode atanguer a todas as demais. A súa experiencia do espazo non é nin simplemente contemplativa, nin sabedora, senón sobre todo corporal. Na súa calidade de afeccionados á marcha, á equitación, ao cicloturismo, á vela, ao rafting, ao surf ou ao barranquismo, senten en primeiro lugar no seu co rpo o espazo que atravesan, con dor ou con alegría. O espazo é, fundamentalmente, un lugar de busca de sensacións e emocións: velocidade, vertixe, dor, pracer, inquietude, medo, etc. Os intentos de autosuperación, a asunción de riscos e a procura dos límites físicos alimentan os desafíos impostos aos outros e a un mesmo. As paisaxes rurais e litorais tórnanse, xa que logo, o marco ou a base de actividades deportivas normais ou extremas, ás veces un pouco ao xeito dos parques de atraccións. Do mesmo modo, pero máis ordinario, estas paisaxes «incorporadas» son tamén as dos agricultores que aran e segan, dos pastores que guían os seus rabaños, dos apicultores que recollen o mel ou dos ornitólogos que observan -agachados tras das canas, como os cazadores- os paxaros migratorios. Nada de imaxes pin torescas, nin de erudición moi sabedora, senón experiencias ordinarias que xeran recordos, referencias, vencellos ou repulsión ante territorios familiares ou descoñecidos.

Todas estas percepcións do espazo poden atinxir, por separado ou non, a mesma persoa, aínda que as prácticas turísticas e de ocio adoiten unir aqueles que se dedican ao mesmo. Un agricultor ou un cazador poden ser tamén, en lugares diferentes dos da caza ou do campo, turistas estetas ou entendidos, e deportistas apracibles ou extremos.

Non obstante, a cuestión que nos interesa aquí é a de saber como estas percepcións -en especial estas olladas- se asocian ou se exclúen nun mesmo lugar. As visións internas dos iniciados e dos «incorporados», que viven os seus territorios de prácticas -o espazo vivido dos xeógrafos-, teñen tendencia a excluír ou a incluír as visións externas dos estetas e eruditos? Non se dan con frecuencia tensións sociais e conflitos?

\section{Relacións pacíficas ou conflitivas?}

Diante dos mandatos paisaxísticos públicos - preocuparse pola calidade do estilo de vida ou do benestar humano e non humano-, os catro grupos sociais cuxas percepcións da paisaxe acabamos de caracterizar adoptan actitudes moi diferentes. 
No mundo minoritario dos agricultores e empregados forestais que producen o esencial das paisaxes rurais, a creación de regras e normas de obrigado cumprimento provoca dous tipos de comportamentos. Os empresarios agrícolas e forestais, apegados aos valores liberais do mercado de bens, adoitan mostrarse hostís ou desconfiados, e rexeitan que a Política Agraria Común (PAC) condicione a concesión de axudas financeiras á súa produción en función de normas de calidade ambiental e paisaxística. Normalmente, non se preocupan de producir gratuitamente os bens comúns da paisaxe, dos cales non poden tirar beneficio ningún e cuxa produción e mantenza non entran no seu proxecto económico -árbores illadas ou integradas en sebes; ribadas, bancais e terrazas; a auga limpa das capas freáticas, fontes e ríos, a fauna avícola ou entomolóxica silvestre, os camiños de acceso público aos espazos agrícolas, etc.-, agás se estes bens -mesmo caros de producir- melloran ou distinguen os seus produtos, como ocorre coa singularidade das terrazas vitícolas das rexións de Denominación de Orixe Controlada. Neste caso, a produción da paisaxe está internalizada pola empresa; non sucede o mesmo coas bolboretas e os paxaros silvestres.

Pola contra, nas rexións litorais e periurbanas, algúns agricultores móstranse dispostos a diversificar os seus ingresos co agroturismo, os servizos pedagóxicos de pesca ou de caza, os viveiros ou a venda directa. Ao ver dos iniciados, estes agricultores, transformados en urbanos, non perciben a paisaxe como algo exclusivo deles, senón que llela abren aos consumidores das rexións urbanas.

En moitos casos, os seus ingresos poden chegar a ser case totalmente urbanos, ata o punto de ficar desligados da produción agrícola. Así ocorre cos dedicados ao hobby farming -agricultura de pracer-, que conservan, sobre todo na área mediterránea, hortos de oliveiras polo simple pracer da produción propia e o autoconsumo. Xa que logo, estas persoas toman prestadas, cada vez máis, as lentes dos ollares formados ou informados para contemplar ou explicar a súa paisaxe interior, con frecuencia pouco comunicable. Outras modifican radicalmente as súas prácticas ao se adherir a requirimentos ambientais, e lánzanse, así, á agricultura ecolóxica ou ao turismo sostible, que implican a aceptación das novas regras do mercado, como no caso do comercio xusto.

No mundo maioritario dos habitantes permanentes do rural que non son agricultores, os mandatos paisaxísticos e ambientais deberían acollerse por unanimidade. En Francia, por exemplo, as normas urbanísticas e arquitectónicas, 
como as que limitan as molestias sonoras ou visuais, son particularmente precisas nas comunas dos corenta e tres parques naturais rexionais. Estas organizacións, tuteladas polo Estado e as rexións, dispoñen desde a Lei de 1993 de cadansúa carta de boa conduta paisaxística, patrimonial e ambiental, á cal recorre o alcalde de cada comuna para se opor aos proxectos que se consideran desviados das normas ou pouco cívicos: paso de liñas eléctricas de moi alta tensión, canteiras, vertedoiros, fábricas contaminantes, autoestradas, urbanizacións, etc.

Ademais destes marcos, en principio exemplares, o agrupamento das comunas en novas colectividades viuse acompañado por plans e cartas paisaxísticos que levan á práctica un amplísimo número de leis, decretos e circulares vinculantes para os propietarios e promotores inmobiliarios que queiran dispor dos seus bens: prohibición de edificar nas ribeiras, servidume de paso litoral, dereito preferente de compra dos conservatorios do litoral, clasificación dos lugares e monumentos históricos, regulamento das concesións de permisos de obra e de demolición, etc.

O alcance destes dispositivos regulamentarios atinxe tanto a conservación do patrimonio histórico e natural como o desenvolvemento turístico e de ocio, a restauración dos lugares degradados - parcelas industriais abandonadas ou activas- ou a creación de novas paisaxes - turbinas eólicas, hoteis, urbanizacións, zonas de actividade comercial e artesanal-, e teñen como obxecto reforzar ou crear o atractivo e a identidade dos territorios rurais a partir de sinais de memoria -lavadoiros, cruceiros, cabanas de pedras secas para habitación temporal, choupanas vitícolas ou pesqueiras, vertedoiros de cascallos da minaría, terrazas vitícolas, árbores senlleiras, lugares relixiosos, etc.-, mais tamén novos -turbinas eólicas, arquitectura innovadora, en especial a de Alta Calidade Ambiental. Ademais, as prácticas de decoración das vilas, como os adornos florais, moi promovidas polos poderes públicos, adoitan ser ben acollidas polos habitantes.

Pola contra, a hostilidade dos residentes cara ao campo desátase cando a acumulación de normas e regras se torna pesada ou lles impide, por exemplo, a innovación arquitectónica. Cando a hiperregulamentación fai uniformes as urbanizacións e crea estilos neorrexionais insípidos, como o bretón, alsaciano, normando, provenzal, poitevino, etc. Cando os adornos florais ou verdes se volven artificiais e disfrazan dubidosas segregacións sociais. Incorporadas, iniciadas, ás veces entendidas, as percepcións da paisaxe son máis ben endóxenas e territorializadas, e adoitan estar afectadas pola síndrome SPAN (Si, Pero Aquí Non). 
A última categoría é a dos residentes secundarios e a dos propietarios dunha segunda vivenda. Aínda que non pasan no campo máis que varias semanas ou meses no ano, adoitan converterse posteriormente en futuros residentes principais cando lles chega a xubilación. Primeiro poñen os lentes do esteta formado e ceden diante do impulso de mercar unha casa de vacacións e, despois, toman prestados os lentes do «incorporado»-ocio externo- e do «informado», e mesmo do «iniciado». Gustan dos mandatos paisaxísticos mentres conserven o marco que eles adoptaron e afasten as actividades indesexables -industrias contaminantes, prácticas agrícolas molestas, caravaning indisciplinado, estradas e turbinas eólicas demasiado ruidosas, etc.-; mais rexeitan os devanditos requirimentos cando lles impoñen excesivos límites para ampliar a casa, cos seus regulamentos sobre a superficie, as formas, os materiais ou cores das fachadas ou as luces. $\mathrm{Na}$ paisaxe -que debe ficar inmobilizada- radica para eles a primeira razón que invocan no caso de se planearen modificacións perceptibles na súa contorna máis próxima -un parque eólico, unha estrada, vivendas... Esta contorna escollida é, ao seu ver, eterna. Toda mudanza contraria aos seus proxectos constitúe irremediablemente un motivo de protesta e de mobilización activa. Toda ruptura do marco escollido é sentida con dor, sobre todo se vén imposta desde fóra.

As sociedades rurais de hoxe xa non teñen moito que ver coas sociedades agrarias de outrora. Influídas pola penetración das culturas urbanas que idealizan o campo, tenden a naturalizar e a normalizar os requirimentos paisaxísticos, como ocorreu na meirande parte dos países do norte de Europa. Estes mandatos permítenlles adaptar o vello marco agrario á sociedade «rurbana» actual; as explotacións agrícolas transfórmanse en casas de campo, residencias, museos ou hoteis, as eiras en xardíns, as pistas agrícolas en sendas de paseo, os estanques, marismas e explotacións en lugares pedagóxicos, os vellos hortos en sitios de recreo, as pistas forestais en itinerarios para practicar a carreira a pé ou a equitación, os campos en parques públicos arborados ou parques de atraccións, os antigos polígonos industriais en restaurantes, estudios cinematográficos ou lugares destinados a exposicións ou ao teatro, etc.

Esta mutación non se fai sen tensións e conflitos entre os que manteñen diferentes puntos de vista, sobre todo entre os empresarios agrícolas que aínda quedan e a maioría dos demais habitantes. Os países agrícolas resístense aínda aos cantos das sereas paisaxísticas. Mais como? 


\section{A GOBERNANZA DAS PAISAXES RURAIS: O RETO DA AUTENTICIDADE}

\section{Un marco híbrido entre cidade e campo}

Nas visións utópicas do campo posmoderno dos paisaxistas urbanistas e arquitectos paisaxistas, a paisaxe converteuse en Europa nunha noción fundamental desde hai máis de vinte anos (Donadieu, 2006b, p. 36-45). Non só se presenta como «un filtro sensorial de enfoque variable» para pensar a cidade horizontal no seu territorio, senón que tamén lles promete a cidadáns e turistas novas imaxes e lugares da vila que xa non separan os espazos rurais ou naturais dos que non o son. Nesta concepción posmoderna das rexións urbanas e rurais maniféstase a preocupación dos arquitectos paisaxistas e dos paisaxistas urbanistas por se erixir en xeradores de proxectos previos á planificación urbanística, e tamén como capataces, xunto con outros, de accións concretas de ordenación espacial das infraestruturas urbanas e rurais.

Ao contrario do que acontece coas industrias, que deixan ruínas tras de si, as actividades agrícolas, xa se sitúen preto ou lonxe das cidades, non morren bruscamente, senón que se transforman devagar. As agriculturas rurais, por diversificación e pluriactividade, tórnanse agriculturas urbanas que se volven cara á cidade e, posteriormente, en agriculturas e xardinarías non comerciais, ata chegaren á etapa final do espazo paisaxístico, que adoita excluír as actividades de produción agrícola. Estas catro etapas espaciais constitúen, xunto coas plantacións forestais e os espazos acuáticos, un patchwork de procesos híbridos -entre natureza e cidade- que producen a infraestrutura material paisaxística da rexión urbana, así como a das súas imaxes.

Para que as actividades agrícolas atopen un lugar normalizado na rexión urbana ou periurbana, é preciso que tanto os poderes públicos como os deseñadores urbanos lles dean unha utilidade e un lugar físico e social que as consagren como bens comúns urbanos, á mesma altura que os parques arborados, as autoestradas urbanas e os cemiterios; mais lembrando que o mercado non produce espontaneamente paisaxes satisfactorias, agás se os encargados das obras públicas e privadas se preocupan diso.

Velaí a razón de que resulte esencial acadar unha alianza entre urbanistas do landscape, os cargos políticos electos e as organizacións agrícolas e xardineiras a 
fin de orientar o tecido urbano mediante unha ampla gobernanza dos proxectos agrícolas e agrourbanos. Ao radicar o reto social na calidade dos estilos de vida periurbano e rural, que non pode ser uniforme, as paisaxes están en condicións, daquela, de se converteren nun «carácter» socialmente distintivo dalgúns barrios da cidade e de partes do campo.

\section{Entre o mandato público autoritario e a autonomía local de decisión}

Presentados polos técnicos, urbanistas, arquitectos e paisaxistas, o mandato ou a invitación paisaxísticos fornecen sobre todo visións «formadas» e «informadas», externas aos territorios rurais. Depositarios dos valores das culturas urbanas, os produtores de normas paisaxísticas, ambientais e urbanas no marco de proxectos territoriais ofrecen, en primeiro lugar, unha información descendente (top down) desde o lexislador cara ao propietario, o arrendatario ou o usuario do espazo. Estas normas imporánselle por lei á persoa administrada; de non ser así, non producen efectos sobre a produción das paisaxes. Para que se poidan impor, os políticos nacionais e rexionais «consultan» os técnicos do Dereito antes de votaren sobre estas normas. De igual modo, cando a norma paisaxística se concibe a escala local, nos países da Unión Europea é obrigatorio que os servizos da Administración organicen un debate público, en aplicación da Convención Europea de Aarhus.

Cando son demasiado restritivas, as normas sobre a paisaxe e o contorno non poden aplicarse de maneira xusta; pero se resultan moi vagas, non xeran resultado ningún e son impotentes. Cando non se avalían, os seus resultados permanecen ignorados. Así, en Francia, a esixencia de obter unha "folla paisaxística» da licenza de obras evita, sen dúbida, graves erros, mais os técnicos do Estado seguen a ter moitas dificultades para xulgar estes documentos administrativos e a súa decisión, con frecuencia, é arbitraria, polo cal queda suxeita a litixios xurídicos e á intervención de peritos.

Nos mellores casos de toma de decisións públicas top down, dáse unha cooperación -ou máis ben unha transacción- entre quen fai aplicar os regulamentos locais nunha colectividade e o que debe aplicalos. O propietario dunha casa de futura construción, por exemplo, ha de adoptar as normas de altura e pendente dos teitos, ou as da forma das fiestras, sobre as que decidiron os cargos políticos dunha colectividade, aconsellados por un técnico de urbanismo. Estas 
normas tórnanse, xa que logo, nunha ferramenta de fabricación da identidade local das paisaxes urbanas da colectividade. Tales obrigas deben ser flexibles e permitir que o propio técnico, no nome do carácter do lugar que se vai crear, autorice a un arquitecto -por exemplo, de edificios públicos- a crear unha forma innovadora para fachadas e fiestras na mesma vila rural.

Por este motivo, o máis frecuente é que a gobernanza das paisaxes requira intercambio, codecisión e implicación dos interesados, tanto públicos como privados. Un camiño agrícola comunal suprimido ou privatizado por un agricultor pode crearse ou abrirse de novo, cando o solicitan os políticos para o destinar a usos de paseo. Poden reformarse sebes cedéndolle á colectividade os terreos agrícolas necesarios. Pódense acondicionar para uso público as marxes dos regatos e dos estanques, con ou sen compra posterior delas por parte da colectividade. A «publicitación» do espazo privado rural constitúe un proceso xeográfico que crea os bens comúns paisaxísticos. Deste xeito, somete o obxecto presentado a regras de civismo ou de cidadanía que varían moito dun lugar a outro, polo cal son frecuentes as tensións entre as persoas -actores públicos ou privados- que desexan instalar parques eólicos, criadeiros, vertedoiros, estradas, incineradoras, etc., e as que se ven afectadas por estas novas veciñanzas, consideradas molestas. Os riscos para a paisaxe e a contorna, apreciados polas "poboacións», avalíanse así nun proceso democrático que pode transformarse en proxecto de autodesenvolvemento sostible (Magnaghi, 2005).

A toma pública de decisións pode delegarse na colectividade local nun marco autónomo, sen que necesariamente se faga notar o peso do Estado. Neste marco de participación, ao que ás veces incitan as rexións de Europa, a regulación faise sobre todo bottom up. Os actores agrícolas poden abrir ao público os seus territorios para fins comerciais, permitir visitas aos seus viñedos ou hortos, propoñer produtos máis ou menos procesados, aloxar turistas, ofrecer servizos de ocio e restauración e facer dos valores da sostibilidade argumentos comerciais. O que non exclúe -ben ao contrario- que os servizos públicos controlen o carácter das paisaxes -en termos ambientais ou patrimoniais. Ademais, neste marco, as decisións públicas, tomadas polos actores locais e as organizacións non gobernamentais, adquiren unha maior lexitimidade social, pois chaman ao recoñecemento da expresión de proxectos individuais e colectivos, así como á súa xerarquización. 
Estes tres niveis de gobernanza, top down, bottom up e híbrida, organizan a interacción dos catro niveis de percepción da paisaxe en cada colectividade. Ás percepcións formadas pola arte, engádenselles as informadas pola influencia das ciencias; e ás percepcións polisensoriais da paisaxe por parte dos habitantes, o coñecemento dos proxectos dos actores agrícolas, cinexéticos e forestais. As gobernanzas que xestionan as decisións están, así, a cargo da xestión dun ir e vir permanente entre os intereses locais territorializados e os intereses colectivos e globais a escala planetaria. Deste xeito, as decisións tomadas interprétanse nas paisaxes percibidas e fabrican a identidade pública das colectividades, lonxe ou preto das respostas locais fornecidas para ter en conta os valores do desenvolvemento sostible. En consecuencia, unha paisaxe sostible -que é un proxecto posible de bens comúns sostibles- ha de expresar unha escolla perceptible sobre a creación de emprego e vivendas sociais, a conservación dos recursos naturais, a mesturanza do espazo público e a diversidade cultural dos grupos sociais. Cando ocorre o contrario, unha paisaxe pode traducir unha división por comunidades, unha segregación social, un desbaldir dos recursos enerxéticos, unha indiferenza diante da conservación ou a recreación da biodiversidade ou das molestias das proximidades.

Os niveis de responsabilidade política han ser de dominio público a fin de que, se os bens comúns que se deben crear non se teñen en conta a escala local, os organismos sociais adopten o recurso -a subsidiariedade- a un nivel superior de resposta colectiva -o Estado, a rexión, o grupo de comunidades. O mesmo pode dicirse se os poderes públicos, desde a comunidade ata o nivel internacional, non desempeñan o papel que se espera deles, o servizo do interese xeral.

\section{E a autenticidade das paisaxes agrícolas?}

Neste contexto democrático, a cuestión da autenticidade das paisaxes rurais presentadas regúlase tanto mediante a participación dos habitantes como a dos actores públicos a todos os niveis. En efecto, é auténtico o que se recoñece como verdadeiro e non como falsificación. Se unha colectividade admite que o seu campo debe resultar atractivo para os turistas e os habitantes e estar producido, sobre todo, por unha agricultura de servizos públicos paisaxísticos, tal colectividade proverase dos medios financeiros para fabricar o seu campo con este tipo 
de empresas, dirixidas aos consumidores da paisaxe e das actividades de lecer. A agricultura de pracer, a agricultura ecolóxica, a xardinaría e as políticas de zonas verdes periurbanas constitúen, entre outros, algúns dos medios lexítimos de xestión dos "parques agrourbanos» (Donadieu, 1998) ou os espazos de tipo "terceira paisaxe» ${ }^{4}$ que favorecen estas prácticas sociais.

Pola contra, se os actores agrícolas desexan perpetuar unha agricultura empresarial, dirixida en primeiro lugar ás bolsas de cereais de Chicago ou de Detroit, poden convencer os habitantes do rural da identidade auténtica das paisaxes de cultivos de cereais así producidas. Resultaralles máis doado facelo se son viticultores e produtores de viños con DOC, especialmente se operan nas paisaxes culturais incluídas na lista do patrimonio mundial da UNESCO: en Cinque Terre (Liguria) ou Saint-Emilion (Bordeos). Cando as imaxes da paisaxe entran na mediación paisaxística, presentan os elementos estetizándoos ou documentándoos, e non afeándoos. Neste sentido, adoitan ser parciais -nos dous significados da palabra-, mais sacan á luz o que é descoñecido e non desexa seguir séndoo. Toda paisaxe é estetizable, o cal lles encanta ás visións formadas, pero debe ser tamén obxecto de influencias informadas e de documentación se o espectador pretende ir alén das aparencias, o que implica a presenza das outras visións: as «iniciadas», as «informadas» e as «incorporadas»; e iso implica tamén a presenza doutros valores éticos na transmisión da paisaxe ás xeracións futuras, como os do desenvolvemento sostible.

\section{$\mathrm{O}$ que din ao respecto os investigadores franceses}

Reunidos recentemente, en abril de 2008, en Versalles para honrar a memoria de Jean-Pierre Deffontaines, xeoagrónomo pioneiro da investigación agronómica das paisaxes agrícolas, os investigadores confirmaron as evolucións arriba indicadas.

$\mathrm{Na}$ actualidade, o $60 \%$ do territorio francés está destinado a usos agrícolas e, para o xestionar, cada vez existen menos agricultores e dáse unha demanda residencial e turística cada vez maior para acadar unha mellor habitabilidade do

\footnotetext{
${ }^{4}$ Segundo o paisaxista Gilles Clément, trátase de espazos que carecen doutros usos sociais que non sexan os de acadar unha biodiversificación sostible a escala local e global.
} 
campo -accesibilidade para as actividades de lecer e superior calidade de vida. Fronte a esta demanda social de calidade das paisaxes, os científicos admiten que a noción de "paisaxe» é tanto unha percepción humana e unha representación do espazo como un espazo material obxectivo. A relación existente entre estes dous polos, o subxectivo e o obxectivo, fai do campo un obxecto de desexo social, mais non hai consenso sobre o que deben ser estas paisaxes, que se tornan así en desafíos sociais, sobre todo para as políticas públicas agrícolas e paisaxísticas. Uns insisten na paisaxe como produto -en permanente evolucióndas actividades agrícolas, e como reflexo das políticas públicas nas que se enmarcan estas; outros, nos vínculos comerciais que se deben establecer entre a calidade dos produtos agrícolas - por exemplo viños e queixos- e as paisaxes que os producen. A maioría coincide en constatar que, no período produtivista da agricultura administrada, a forma das paisaxes disociouse do medio natural e humano que as producía, e que resulta indispensable restablecer este vencello que descoidaran os agrónomos e os agricultores. Entre a agricultura de servizos e a agroindustria, algúns recomendan a agricultura rexional ligada á valoración e á conservación dos recursos locais -enerxía, auga, solo, medios naturais-e aos valores do desenvolvemento sostible. Outros identifican o xurdimento de novos colectivos agrícolas e non agrícolas aos que lles incumbe a valoración dos espazos marxinados pola agroindustria; por exemplo, recuperación das terrazas agrícolas abandonadas, das zonas húmidas ou dos ermos postindustriais e urbanos.

Faise tamén a constatación de que as calidades do nivel de vida rural -a pureza do aire e da auga, a limpeza dos solos, a riqueza da biodiversidade, o atractivo das escenas paisaxísticas, a diversidade do patrimonio histórico, a facilidade de acceso- son fonte dun maior benestar tanto dos habitantes -incluídos os agricultores- como dos turistas. Estas calidades soñadas, frecuentemente mitificadas, fan do campo un refuxio antiurbano e un lugar nostálxico de solidariedade social e de benestar humano. Os científicos, referíndose ás investigacións agronómicas sobre a nutrición humana, que amosaron a importancia da percepción sensorial -o sabor- dos alimentos, coidan que os traballos dos investigadores agrónomos deben centrarse a partir de agora na percepción das paisaxes, eido que xa exploraron os sociólogos, os etnólogos e os xeógrafos. O proxecto paisaxístico, familiar para os paisaxistas, preséntaselles como unha ferramenta de cualificación global das paisaxes en evolución e como un medio 
local de levar á practica un sistema de gobernanza dos proxectos territoriais cos actores locais.

\section{CONCLUSIÓN}

As sociedades rurais europeas arríscanse a quedar divididas en catro categorías de relacións cos espazos agrícolas e arborados: favorecer a agricultura e a xardinaría de servizos a escala local, máis que as destinadas aos produtos agroindustriais que conveñan ás prácticas residenciais, turísticas e de lecer, nos espazos «rurbanos» multifuncionais integrados nas rexións urbanas e destinados a permanecer alí. Favorecer o mantemento de agroindustrias que despachan produtos a escala local e mundial nas rexións agrícolas mecanizables e que acotío carecen de actividades de ocio e prácticas turísticas ou de descanso na vila. Facer isto mesmo lonxe das cidades, nas zonas agrícolas pouco favorables para a mecanización -montañas, zonas húmidas-, recorrendo á agricultura de servizos, financiada polas colectividades e por Europa e destinada a limitar as plantacións forestais e os riscos -incendios, erosión, inundacións- e a favorecer as economías residenciais e turísticas. Ou ben, finalmente, nos tres casos anteriores, recorrendo aos valores do desenvolvemento sostible, a fin de poñer en marcha proxectos rexionais desde unha perspectiva de autodesenvolvemento sostible localizado.

Segundo sexan as producións e os seus proxectos, os agricultores veranse, pois, en dúas situacións moi diferentes: ou pretenderán resistirse ao proxecto paisaxístico público e sostible escapando del -deslocalización fóra de Europa ou lonxe das cidades-, ou ben o integrarán nas súas actividades comerciais para facer del, xunto cos habitantes dos territorios e rexións agrícolas, un activo local para o desenvolvemento sostible. Corresponderalles aos poderes públicos das colectividades, especialmente as urbanas, atopar as regras de gobernanza necesarias para elixir e enmarcar estas mudanzas. 


\section{BIBLIOGRAFÍA}

Donadieu, P.: La société paysagiste, Actes Sud/ENSP Versailles, 2002. [Hai edición en castelán].

Donadieu, P.: «De l'utopie à la réalité des campagnes urbaines», Urbanistica, n. ${ }^{\circ} 128,2006 a$, p. 15-20.

DONADIEU, P.: «Landscape urbanism in Europe: from brownfields to sustainable urban development», JoLA (Journal of Landscape Architecture), n. ${ }^{\circ}$ 2, Autumn, 2006b, p. 36-45.

DONADIEU, P.: «Le paysage, un paradigme de médiation entre l'espace et la société», Economie rurale, n. ${ }^{\circ}$ 297-298 (introduction d'un dossier «Paysage»), 2007.

Donadieu, P. e E. MaZas: Des mots de paysage et de jardin, Dijon, Edisud, 2002.

Donadieu, P. e M. PÉrigord: Clés pour le paysage, Gap, Ophrys, 2005.

Donadieu, P. e M. PÉRIgORD: Le paysage entre nature et culture, Paris, A. Colin, 2007.

Magnaghi, A.: The urban village, a charte for democracy and local self sustainable development, London/New York, Zed Books, 2005. 

Retruque

\title{
OS COMEDORES DA PAISAXE*
}

\author{
Albino Prada Blanco
}

Universidade de Vigo 

O meu agradecemento aos responsables deste foro de debate debe ser dobre. De entrada, por considerar que un economista puidese ser útil para realizar unha ollada crítica sobre un asunto como o da paisaxe. Mais tamén por terme encargado comentar o iluminador relatorio que co título Aceptaron as sociedades rurais europeas as políticas paisaxisticas públicas? vén de presentar Pierre Donadieu e que eu tiven a fortuna de poder ler devagar previamente nun texto daquela titulado: As sociedades rurais europeas teñen asumido as politicas públicas sobre a paisaxe?

$\mathrm{Na}$ miña lectura e na posterior exposición con acaídas imaxes nesta sesión tiven claro que o relator -e grande experto francés- barallaba sobre o tema as pezas esenciais do problema. Os distintos perceptores e usuarios da paisaxe rural por unha banda, os agricultores e produtores da paisaxe, por outra, e as administracións públicas -desde as locais ata as europeas-, por outra. Pezas ou actores dun drama actual que se manifesta en dous comportamentos e procesos extremos: o abandono e a intensificación. Dunha banda, a incapacidade para mobilizar e xestionar unha boa parte da superficie rural -non xa a de vocación forestal ou silvícola, mesmo tamén de pastos ou cultivos- nun proceso de despoboamento galopante dos núcleos rurais e, doutra, unha concentración tecnolóxica -maquinaria, adubos químicos, rega artificial, fitosanitarios, etc.- extrema sobre unha pequena parte do territorio rural -das granxas sen terra, aos invernadoiros, ata chegar ás plantacións lignícolas forestais. E polas dúas vías, unha transformación radical da paisaxe rural que herdaramos do vello complexo agrario tradicional.

Quero, xa que logo, centrar a miña atención nestes actores rurais e neste drama da paisaxe e do territorio e deixar a un lado outros argumentos ${ }^{1}$ que non

\footnotetext{
${ }^{1}$ Debo sinalar - polo menos- dous dos que me teño ocupado recentemente. Un vai ser o fenómeno da dispersión como forma de crecemento do urbano e como metástase do rural, que asociado á mobilidade do automóbil privado teño analizado na revista Grial -números 176 e 177- co título «Causas e custes da dispersión». Outro sería o particular caso do rural no litoral, onde os usos non agrarios relacionados co turismo, a acuicultura, a navegación, etc. deben ser especialmente tidos en conta; estamos a traballar na cuestión nun proxecto de investigación en curso.
} 
lles son alleos, pero que nesta ocasión complicarían e espallarían de máis a miña tarefa. E quero que o meu empeño sexa útil para, de camiño, facérmonos unha opinión crítica sobre o proxecto de Lei de protección da paisaxe de Galicia que o Goberno galego vén de aprobar ${ }^{2}$. Decateime moi pronto de que o problema viña xa de bastante atrás, como o recollera nunha das súas Cousas da Vida o grande observador do mundo rural de comezos do século XX que foi Castelao.

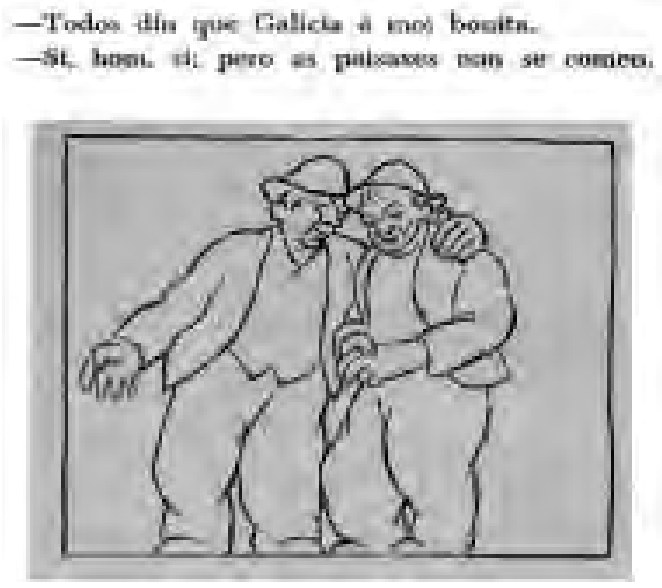

Porque como resultado deste "paradoxo» van xa case cen anos nos que, como as paisaxes non se comen, centos de miles de paisanos deixaron as súas aldeas e terras nun xigantesco éxodo migratorio para gañar a vida e, de resultas diso, vai case un século en que o abandono da maior parte da nosa terra e o uso intensivo -ás veces tamén absentista- doutra boa parte fixeron que Galicia deixara de ser tan «bonita».

Cómpre que hoxe nos preguntemos se a sociedade -o «todos din» de Castelao, a demanda para a economía - ten unhas preferencias pola paisaxe rural distintas da súa situación real; se unha sociedade maioritariamente non rural ten un criterio sobre como debera estar a maior parte do territorio do país -que é rural, aínda que xa non agrario-; e se tamén hoxe os agricultores e residentes no

\footnotetext{
2 Pódese consultar o texto da proposta e un ditame ao respecto en: http://www.ces-galicia.org; o proxecto fora aprobado no Consello da Xunta do 27 do marzo de 2008.
} 
rural -os que din que «non se comen», os produtores da paisaxe, o lado da oferta en economía- están dispostos, e en que condicións, a producir segundo que modelo de paisaxe. O que opine a sociedade, a demanda, é tamén crucial no articulado da devandita Lei de protección da paisaxe de Galicia -artigos 3.a.; 3.c.; e 10.2- porque está na definición ${ }^{3}$ da paisaxe como "calquera parte do territorio tal como a percibe a poboación» e mesmo na definición da súa calidade como «aspiracións da colectividade».

Polo lado da demanda, temos realizado dúas enquisas a unha mostra representativa da poboación galega. Unha para coñecer as súas preferencias (Prada, Vázquez e Soliño, 2005) sobre a cuberta arborada nas áreas de montaña do país -fronte ao uso actual de plantacións de eucaliptos e piñeiros- e outra para saber se estaban dispostos (Prada, Vázquez e Soliño, 2006) a apoiar unha xestión sostible da biomasa residual forestal -fronte ao abandono actual do monte baixo e o ciclo catastrófico dos incendios forestais.

No primeiro caso, partimos da elaboración dun índice de preferencias paisaxísticas (IPP) ${ }^{4}$, a partir de dezasete atributos cos que se codificou un conxunto de fotografías que os entrevistados debían ordenar por dúas veces. Centrámonos na cuberta vexetal e excluímos os cursos de auga, muros, construcións, camiños ou tonalidades estacionais. Os resultados obtidos -consistentes e robustosdecántanse polos bosques de caducifolias fronte ás plantacións, con tratamentos non lineais, con masas mixtas, adultas, non coetáneas e con arborado ocupando máis da metade do espazo de montaña, mais sen chegar ao cen por cen. Serían estas os nosos «regards, perceptions, sensations, emotions» que sinala no seu relatorio o profesor Donadieu. Como se pode observar nas imaxes que reproducimos, entre as utilizadas no traballo de campo co seu IPP, as semellantes ás de menor valoración foran curiosamente utilizadas como promoción dos usos turísticos no rural galego en 2003. É boa nova recoñecer que catro anos despois a promoción pasou a facerse con imaxes semellantes ás máis valoradas segundo o noso traballo de 2006.

\footnotetext{
${ }^{3}$ A lei galega copia nesto a catalá 8/2005, que no seu artigo 3 define a paisaxe como «calquera parte do territorio tal e como a colectividade a percibe».

${ }^{4}$ Traballos previos nesta dirección serían os de Kaplan e Kaplan (1989), Tempesta (1993), Falini e Ciardini (1985) ou Daniel e Boster (1976), entre outros que citamos na nosa publicación sobre a Rede Natura 2000 (Prada, Vázquez e Soliño, 2005).
} 
Campaña Turgalicia 2003

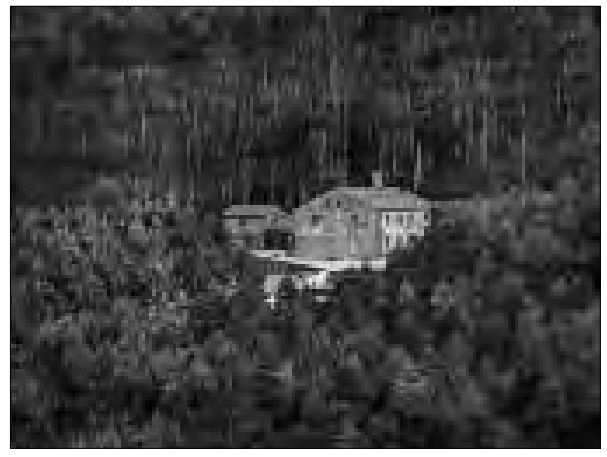

Campaña Turgalicia 2007

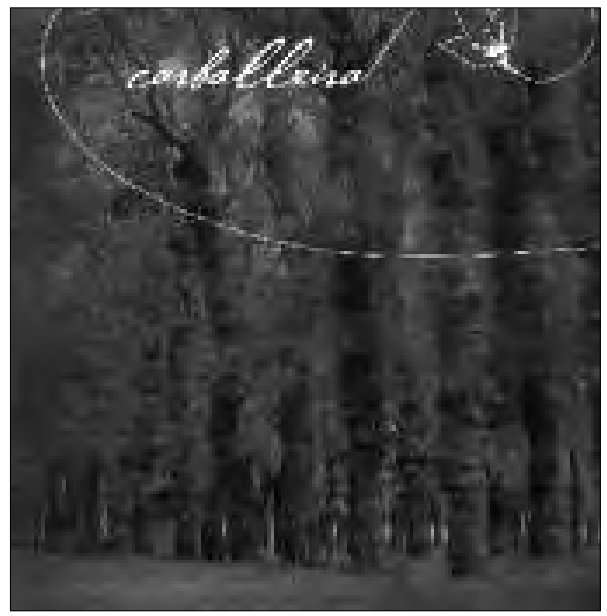

IPP moi baixo (2,9 sobre 5)

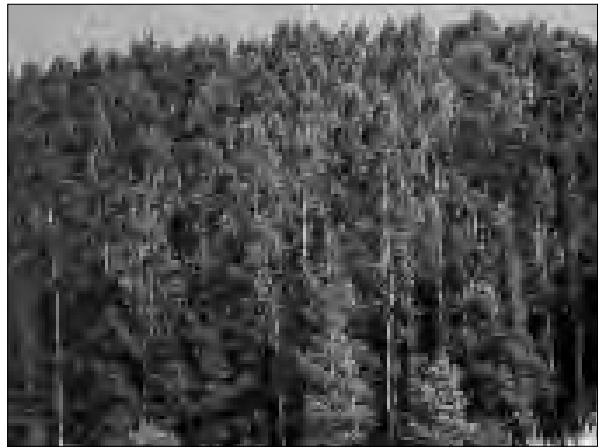

IPP moi alto $(4,4$, sobre 5$)$

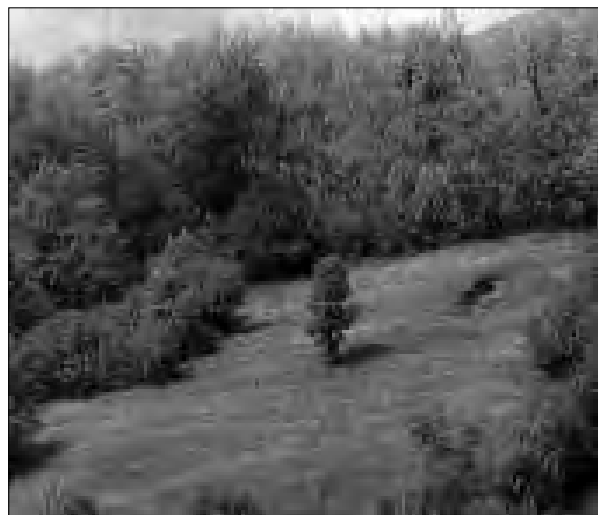

Complementariamente, realizouse un experimento de elección cos atributos e niveis paisaxísticos máis apreciados pola poboación galega para estimar a disposición a facer un pagamento -mediante unha recarga anual no IRPF- para dotar un fondo que financiase a xestión dos montes dos espazos da Rede Natura 2000 de Galicia. Obtivemos unha cifra - previos todos os filtros e precaucións para evitar interpretacións e condutas compracentes- de 330 euros por hectárea e ano. En función destas percepcións, aspiracións e valores sociais podemos con- 
cordar que a sociedade galega «recoñece que a paisaxe é un elemento de benestar individual e colectivo que ademais de valores estéticos e ambientais ten unha dimensión económica»"s.

No caso da nosa pescuda sobre a xestión sostible do monte baixo, a sociedade galega manifesta valorar especialmente a potencialidade desta política para xerar emprego no mundo rural e para evitar gastos nos programas de extinción de incendios forestais; tamén o feito de valorizar unha fonte enerxética limpa e renovable que substitúe combustibles fósiles e, sen dúbida, o seu efecto directo na redución da gravidade dos incendios forestais e dos seus efectos catastróficos -en extensión, en reiteración. Nese contexto, comprobamos tamén unha preocupación por evitar, na medida do posible, o impacto dos aproveitamentos eólicos nas nosas serras. Como no caso das preferencias polo arborado, a disposición ao pagamento -aquí como unha recarga no prezo da subministración eléctrica que garantise a procedencia da enerxía deste programa- superaría o custo unitario de extracción, estimado en 582 euros por hectárea, para unha substitución do $10 \%$ da electricidade negra actual por esta electricidade verde.

O que aquí interesa resumir é que por estas dúas vías de xestión da paisaxe -dos arborados e dos montes baixos- non só recollemos as preferencias da sociedade galega senón o seu apoio económico. Se a sociedade quere «comer», comprar, adquirir, esta xestión da paisaxe... é bo saber canto está disposta a pagar por iso. Porque só así outros poderán percibir ingresos e «comer» das paisaxes.

Ten moita razón o profesor Donadieu cando di textualmente no seu relatorio que non se pode producir gratuitamente a paisaxe, que os agricultores deben diversificar as súas rendas por esta vía, que as cousas ben feitas non se producen espontaneamente, en fin, que cómpre facerlle chegar ao mundo rural os medios financeiros para fabricar a paisaxe. E isto é así alén dos Pactos pola Paisaxe ou dos Acordos de Custodia previstos nas leis ${ }^{6}$. E tamén máis alá de que certos produtos ou servizos con mercado se poidan favorecer dun maior valor engadido se a paisaxe é de calidade e está ben conservada -por exemplo nos viños de socalcos ou terrazas, no leite dos pastos, no marrón glacé, no turismo rural, etc.- pois así poderán ter diferenciación na calidade e no prezo.

\footnotetext{
${ }^{5}$ A cita é da Lei de protección da paisaxe catalá, no seu artigo 2.

${ }^{6}$ Artigos 14.3, 14.4 e 14.5 da Lei galega.
} 
Alén destas consideracións, cómpre remunerar os agricultores e os xestores dos montes - no exemplo que centra a nosa atención- polos valores de non uso e de estrita conservación que están a producir e nos de uso -recreo, ocio- que non poden ser capturados polo mercado. A sociedade manifestounos nos traballos de investigación realizados que está disposta..., mais, canto reclaman os agricultores para axustarse a esa demanda e prover esa calidade e xestión da paisaxe?

Pola paisaxe que para a sociedade era de maior calidade -arborados caducifolios, baixa densidade, masas mixtas, non coetáneos, con monte baixo xestionado activamente...- a mostra de trinta presidentes de comunidades de montes veciñais en man común de Galicia entrevistados nunha dobre rolda de análise Delphi definiu unha cifra de 300 euros por hectárea e ano a longo prazo -ademais dos gastos iniciais de plantación e mantemento. Aínda sendo un custo elevado para as axudas e programas existentes, encaixaría ${ }^{7}$ nos topes máximos das políticas de forestación da PAC (Política Agraria Común) e, sobre todo, na disposición social que vimos de resumir máis arriba. Pero xustamente por iso é especialmente preocupante que no proxecto de Lei de protección da paisaxe de Galicia botemos de menos un capítulo de financiamento ${ }^{8}$.

Desta maneira, os nosos traballos daríanlle razón e perspectivas operativas ao enfoque do relatorio que comento. A demanda social dunha paisaxe de calidade pode ser atendida polos produtores de paisaxe pero, para facelo, é preciso que as administracións públicas cumpran o seu papel de prover os recursos. É dicir, transferir parte da renda das familias e fogares non rurais a aquelas do mundo rural que asuman os contratos de xestión da paisaxe. Só así uns poderán «comer a paisaxe» e os outros, "comer da paisaxe».

Iniciado xa o século XXI, a relación entre a cidade e o campo, ou entre o mundo urbano e o mundo rural, nos países desenvolvidos debera ser profundamente reconsiderada. As razóns veñen xa da herdanza do pasado século (Williams, 2001): por unha banda, cidades conxestionadas e campos despoboados e, por outra, unha excedentaria produción de alimentos, obtidos con tec-

\footnotetext{
7 Tamén no caso do aproveitamento sostible da biomasa permitiría a posta a disposición das plantas de valorización de xeito que lles fose rendible a xeración eléctrica co sistema de primas xa vixente.

${ }^{8}$ Que si recolle a devandita Lei catalá, no seu capítulo V, que, neste caso, a galega non segue. Tampouco imita a Lei galega á catalá no seu artigo 8.g., que prevé adquirir solo para incrementar o patrimonio público.
} 
noloxía intensiva e que precisan a cada paso menos terras. Así, nos países desenvolvidos un $80 \%$ das terras -agrarias e forestais- fornecen moito menos do $10 \%$ do emprego.

Por iso, é imprescindible reconsiderar as relacións entre o mundo rural -que ocupa a maior parte do territorio- e o conxunto da sociedade - urbana, industrial e de servizos-, para garantir a conservación deses amplos territorios rurais e de montaña, como recurso natural -ambiental, paisaxístico, enerxético, etc.- e legado para as futuras xeracións. Isto é posible mediante unha xestión activa, sostible e diversificada dos -crecentes e dominantes- espazos rurais non utilizados pola agricultura, que implique e ilusione nesa tarefa os nosos agricultores e a sociedade en xeral. Ese é o obxectivo que, na miña opinión, compartimos o profesor Donadieu e nós mesmos. 
Albino Prada Blanco

\section{BIBLIOGRAFÍA}

Prada, A., M. X. VÁzQuez e M. Soliño: Beneficios y Costes Sociales en la conservación de la Red Natura 2000, Fundación Caixa Galicia, 2005.

Prada, A., M. X. VÁzQuez e M. Soliño: Electricidad verde, la biomasa en los montes de Galicia, Fundación Caixa Galicia, 2006.

Williams, R.: El Campo y la Ciudad, Paidós, Buenos Aires, 2001. 


\section{EPÍLOGO}

Federico López Silvestre

Universidade de Santiago de Compostela 

Todos, ou a maioría, temos na memoria esa imaxe de pasar a fronteira dos Pireneos no coche e atoparnos, de repente, cunha paisaxe que, aínda que xeograficamente debería ser moi semellante á da Península Ibérica, parece distinta. Todos, ou a maioría, cometemos, nalgunha ocasión, o erro de atribuírlle os méritos desa beleza á boa xestión do Estado francés fronte á mala actuación do español. Sen dúbida, temos moito que aprender dos nosos veciños no tocante ás políticas da paisaxe. Sen dúbida, os desfases económicos tamén axudan a explicar as diferenzas. Así e todo, a lección que un aprende cos anos, viaxando a Francia, a Alemaña, a Bélxica, a Holanda ou a Suíza, é que o Estado só ten parte de culpa nesa harmonía e nesa beleza. O certo é que a porcentaxe maior das terras que vemos desde a estrada, tanto a este lado como ao outro da fronteira, non depende da xestión pública, pois son propiedades privadas. O Estado pode axudar pero non facer polos propietarios aquilo que eles non queren realizar por si mesmos nos seus terreos e ferrados. Así, chegamos á cuestión clave en relación coa paisaxe. Hai quen di que falar tanto, de moito non vale; que coa paisaxe cómpre facer máis e falar menos. O foro de debate titulado Olladas críticas sobre a paisaxe trataba de mostrar que, no fondo, ás veces coa paisaxe é mellor falar máis, educar máis e facer menos. Só falando e educando a xente, os propietarios, os construtores, os concelleiros das localidades..., podería darse forma a esa paisaxe fermosa que tantas envexas provoca cando cruzamos a fronteira. De feito, como saben os franceses, os alemáns, os suízos, os belgas ou os holandeses, a educación é a única vía para logralo.

Agora ben, para falar de algo tan complexo como a paisaxe é preciso definila primeiro e logo formar un criterio. De aí a idea das «olladas críticas»: críticas porque aspiran a pensar o "concepto» e non a herdar o "prexuízo», e tamén porque non aceptan as cousas como lles veñen dadas, senón que contemplan a realidade con escepticismo e con afán de mellora. A ollada máis profunda e crítica sobre a paisaxe procede de cando menos dúas esferas. Por unha banda, da esfe- 
ra dos humanistas, que, tentando definir o home, se decataron da importancia do contexto que lle dá forma, e, por outra, da esfera dos científicos, que, tentando definir a natureza, acabaron comprendendo que a ollada do ser humano era a que lle daba a esta o seu sentido e valor. Este foro de debate e este libro, en primeiro lugar, tentaron recoller as achegas duns e dos outros.

$\mathrm{O}$ apartado titulado «O home na paisaxe. Cara a unha filosofía integral da paisaxe desde as humanidades» reúne os humanistas, é dicir, as achegas dalgúns moi reputados profesores de estética, filosofía e antropoloxía da paisaxe. Encabezando o apartado, un pequeno texto resume a idea do pensador e orientalista Augustin Berque, que é posiblemente o teórico da paisaxe máis recoñecido entre os especialistas na actualidade. Director de estudos na École des Hautes Études en Sciences Sociales de París, a súa formulación é crucial para entrar na madurez reflexiva da paisaxe. A paisaxe non é algo material, senón un concepto cultural: hai culturas paisaxísticas e culturas non paisaxísticas. Este carácter vén dado por certo respecto e valoración do medio. Os síntomas que evidencian ese amor son os poemas descritivos, a pintura de paisaxe, os xardíns e as palabras utilizadas para denominar a paisaxe. As culturas chinesa e xaponesa desenvolveron antes que a europea esa noción. En Occidente só a partir do século XVI comezamos a atopar estas valoracións en forma de cadros ou poemas. O interesante é que reflicten unha filosofía ou mentalidade que, para o francés, ten moito sentido no noso presente. $\mathrm{O}$ pensamento paisaxístico asume que a paisaxe, como idea, é froito dunha mestura de elementos materiais fornecidos pola terra e valores e sentimentos intanxibles que achega o home: o que Berque chama a «trajection paysagère». Noutras palabras, non é só que sen mundo non haxa paisaxe, é que sen o home, tampouco. A paisaxe precisa tanto do ser humano como do territorio para existir. Complemento perfecto á teoría filosófica de Berque é o texto de Raffaele Milani. Profesor de Estética da Università di Bologna e un dos principais especialistas europeos no tema, considera tamén que na paisaxe o mundo e o home aparecen fundidos, pois o concepto precisa de ambos os dous: natureza e emoción. Desde esa emoción necesaria para falar dela, a paisaxe pasa a ser materia da Estética. Como noción estética cómpre ter en conta: en primeiro lugar, que pode facer gozar pero que non por iso debe ser entendida como algo simplemente decorativo: a paisaxe é «natureza», o que nos rodea, o lugar onde vivimos, fundamento da «civilización»; en segundo lugar, que é, 
asemade, mundo e «historia», natureza e "cultura», é dicir, froito dunha colaboración, aínda que flutuante; por último, que foi tamén, ata hai ben pouco, na procura de «harmonía». Na actualidade, as cousas están menos claras. A «fin da historia» e a dúbida sobre as estéticas da «harmonía» levan a paisaxe a caer «no baleiro das mudanzas imprevisibles e escuras». Por outra banda, as ideas de Milani verbo das liñas básicas da estética da paisaxe levaron a Marcial Gondar a cuestionar un modo de facer filosofía «urbano», que pretende venderse como «universalmente válido», pero que, desde o seu punto de vista, non se lles pode aplicar a todas as culturas. $\mathrm{O}$ intento do profesor Gondar, catedrático da Universidade de Santiago de Compostela, consistiu precisamente en establecer as bases dun modo rural de ver a paisaxe. Como miran os campesiños galegos a paisaxe? Pódese falar de harmonía entre elas? A súa resposta foi que a estética do campesiño é e será sempre pragmática, non poderá desvincular nunca o bo do fermoso para facer xuízos estéticos «puros». Sexa como queira, lonxe de considerar isto como unha diferenza, o que afirma Gondar é que esa fusión de ocio e negocio deberiamos «vela como unha fortaleza da que os urbanitas podemos aprender». José Antonio Fernández de Rota, catedrático da Universidade da Coruña, parte da súa ampla experiencia como antropólogo para revisar as tendencias fundamentais de aproximación á paisaxe desde a disciplina e propón que as novas liñas de investigación, lonxe de aceptar o paradigma tradicional baseado no método materialista de estudo das formas de organización do territorio e das prácticas e usos que se lle dan, mergullen na nova análise simbólica. Esta acepta que a paisaxe se constrúe fisicamente, pero, asemade, insiste en que tamén se constrúe simbolicamente, mediante verbas e códigos culturais. O certo é que nisto o texto de Fernández de Rota enlaza cos citados. Nesa idea comezo a insistir eu mesmo cando avanzo a posibilidade dunha filosofía integral da paisaxe. Concretamente, para falar dela poño primeiro como exemplo a fenomenoloxía de Tetsuro Watsuji, na que se inspira o propio Berque, e que afirma que a paisaxe é, asemade, mundo e suxeito. Aínda que ao final engado a especulación fundamental do idealismo obxectivo sobre a natureza do suxeito e a subxetividade da natureza.

As teorías da paisaxe mantidas polos humanistas, moi críticas coa perspectiva científica obxectivista que identifica a paisaxe coa materia, sen dúbida contan nesta obra cunha boa resposta. Ningunha das propostas esgrimidas polos espe- 
cialistas na análise ecolóxica, xeomorfolóxica ou xeofísica que se atopan no apartado denominado «Do territorio á paisaxe. Análise da paisaxe desde as ciencias naturais» cae no rudo materialismo: todas elas afirman o seu interese pola visión holística. A Ecoloxía da paisaxe de Francisco Díaz Pineda, discípulo avantaxado de González Bernáldez e catedrático da Universidad Complutense de Madrid, trata de explicar as relacións ocultas da imaxe percibida polo observador -puntos de vista termodinámicos, xeofísicos, xeoquímicos, fisiolóxicos, demográficos, biolóxicos-, prestándolle moita atención á relación entre ese medio natural e a sociedade humana. Carlos Vales, director do Centro de Extensión Universitaria e Divulgación Ambiental de Galicia, segue as liñas trazadas por Díaz Pineda. Para a Ecoloxía, a paisaxe é o conxunto de hábitats que existen sobre un territorio determinado. En tres sentidos a Ecoloxía da paisaxe pode serlle moi útil á sociedade actual: en primeiro lugar, permite albiscar algúns dos elementos máis valiosos das nosas paisaxes tradicionais, valoradas pola nosa cultura; en segundo lugar, axuda a interpretar os cambios paisaxísticos en marcha sobre bases conceptuais minimamente sólidas; e, en terceiro lugar, amplía o criterio tradicional do que é a paisaxe. Se os ecólogos formulan a definición das paisaxes partindo dos hábitats ou ecosistemas, os xeógrafos prefiren fixarse no «carácter» destas para establecer «tipos». Así o explica o catedrático da Universidad Autónoma de Madrid, Rafael Mata, que renuncia a escoller entre a posición subxectivista dos literatos e a outra realista dos científicos, e que, por iso, para elaborar o catálogo de tipos de paisaxes de España subliña a necesidade de ter en conta os factores físicos que se poden cartografar e das imaxes culturalmente construídas destas. Pola súa banda, Pablo Ramil, profesor da Universidade de Santiago de Compostela e director do Instituto de Biodiversidade Agraria e Desenvolvemento Rural, trata de matizar as teorías de Rafael Mata cun comentario en que denota ter asumido as teses da Ecoloxía: «a conservación da paisaxe galega atópase nun momento crucial [...]. E por iso as clasificacións das paisaxes deben de cubrir, ademais dos formalismos sistemáticos, aspectos fundamentais ligados ao estado de conservación destes».

A terceira parte desta obra, a titulada «Pasado e presente da paisaxe. Do discurso da paisaxe ás paisaxes sen discurso", ata certo punto, desenvolve as frustracións que nos poboadores provocan as novas paisaxes do progreso, unhas paisaxes que pouco teñen en conta esa conservación da que falan os científi- 
cos. De feito, o problema non é só físico: a sociedade aparece vinculada a certas paisaxes, as paisaxes da tradición, as paisaxes con discurso, e tarda en asumir os rápidos cambios provocados polo mundo actual. A ilustrar a creación deses discursos culturais por parte dalgúns escritores e políticos galegos a comezos do século XX dedícalle unhas páxinas Caroline Domingues, profesora da Université Blaise Pascal en Clermont-Ferrand e especialista no estudo do papel da literatura e a prensa na formación das identidades. E de falar da destrución desas paisaxes con discurso, da formación dos novos espazos transxénicos e do malestar dos cidadáns, ocúpanse en cadanseu capítulo os profesores Álvaro Domingues, da Escola de Arquitectura da Universidade do Porto, e Joan Nogué, catedrático da Universitat de Girona e director do Observatori del Paisatge de Catalunya. Álvaro Domingues, partindo do caso do Porto, insiste nalgúns problemas conceptuais. Sinala que nocións como a do «rururbano" non describen ben esas paisaxes das periferias, que nin son rurais, nin urbanas. Apunta que é mellor referirse ás mutacións xenéticas na paisaxe. E, finalmente, suxire que a estetización da paisaxe, que tenta ocultar os cambios de uso do espazo, non pode evitar que vellos e novos problemas, como a falta de sentido do lugar ou a inxustiza social, agromen. Pola súa banda, Joan Nogué achégase a esa cuestión do «sentido do lugar» cun novo enfoque. Tenta mostrar a súa valía para delimitar sen abstraccións a cuestión da identidade territorial: a identidade, no básico, é a memoria, o sentido de pertenza a un lugar en que naciches ou viviches moito tempo. De aí «a conflitividade territorial contemporánea como reflexo da perda desa identidade e, asemade, do sentido do lugar». Para evitala, finalmente, mostra propostas de xestión que aspiran a preservar ese sentido, esas formas e eses discursos da paisaxe. Fronte a Domingues e Nogué, as lecturas de Julia Fernández e Jacobo García resultan menos críticas e, se cabe, máis tolerantes cos cambios do presente. Julia Fernández de Caleya, arquitecta paisaxista e profesora na Escola Técnica Superior de Arquitectura da Coruña, recolle a intervención de Álvaro Domingues e analiza os espazos concretos do Porto para mostrar de que modo o novo urbanismo pode mellorar e mellora as paisaxes urbanas do noso tempo. Jacobo García Álvarez, profesor de Xeografía na Universidad Carlos III de Madrid, retruca o relatorio de Joan Nogué, tentando mostrar, no básico, a enorme capacidade de adaptación das diferentes poboacións do mundo e a velocidade 
coa que creamos «sentido de lugar» en paisaxes radicalmente novas; un simple Mcdonald's dun barrio periférico pode converterse en lugar de referencia na memoria colectiva dos habitantes da zona.

Finalmente, as intervencións de Pierre Donadieu e Albino Prada acercan este tipo de polémicas ás nosas paisaxes galegas. Os cambios aféctanlle ao sentido tradicional rural de ver a paisaxe e afondan na escisión social. Algúns falamos de protexer a paisaxe do campo, pero, aceptan as sociedades rurais europeas as políticas públicas da paisaxe? Esta é a cuestión que ocupa a Pierre Donadieu, director de investigación da École Nationale Supérieure du Paysage de Versailles. O seu balance, aínda que brillante, lévanos a contemplar con certa inquietude a situación. O choque entre unha forma pública, de ben común, de contemplar a paisaxe -paisaxe como marco vital, como valor patrimonial, como reserva ecolóxica- e un modo privado, mono-funcional -paisaxe como territorio agrario, como explotación, como pago-, obríganos a presentar políticas capaces de facer converxer os intereses público e privado. Pola súa banda, Albino Prada, economista e profesor da Universidade de Vigo, formula as mesmas dúbidas e engade outras. Sabemos, grazas ás estatísticas, cales son as paisaxes rurais galegas máis valoradas. O problema consiste en xestionar a enorme parte desas superficies rurais despoboadas. As únicas solucións son, por unha banda, darlles sentido e valor de uso a esas terras, adaptándoas á economía do presente na medida do posible; e, por outra, fortalecer as políticas de protección da paisaxe con medidas económicas reais. Na nova Lei de protección da paisaxe de Galicia sería preciso, xa que logo, un capítulo de financiamento como o V da Lei catalá. 
CURRÍCULOS 

Augustin Berque. Teórico de grande actividade e «propagandista» da Xeografía cultural, Augustin Berque, nacido en Rabat en 1942, dedícase con gusto á análise comparada. Director de estudos da École des Hautes Études en Sciences Sociales de París, é tamén xeógrafo orientalista e desde hai xa varios decenios centrou as súas actividades intelectuais na relación das sociedades humanas coa súa contorna. Publicou numerosos ensaios sobre estas cuestións, e no ano 2000 sintetizou as súas investigacións e a súa reflexión no libro Écoumène (París, Belin). Asemade, é especialista no Xapón, onde actualmente imparte aulas na Universidade de Miyagi. Ademais de Écoumene publicou unha vintena de obras, entre as cales se contan Médiance. De milieux en paysages (París, Belin, 2000), 5 propositions pour une théorie du paysage (Seyssel, Champ Vallon, 1994), Les sens de l'espace au Japon (París, Arguments, 2004) e, recentemente, a súa colaboración na obra colectiva La ville insoutenable (Belin, 2005). Acaba de publicar Le pensée paysagère (Arquibooks, 2008; en castelán en Biblioteca Nueva).

Francisco Díaz Pineda. Catedrático de Ecoloxía na Universidad Complutense de Madrid desde 1981. Doutorado en 1975, a súa experiencia baséase na planificación territorial; o estudo das bases ecolóxicas da conservación da natureza; a análise de ecosistemas mediterráneos, principalmente de pasteiro, e a regulación da diversidade biolóxica. Actual presidente de WWF-España (ADENA), desde 1995. Membro do International Board of WWF, Gland (Suíza, 1997-01; 2003-07). Membro fundador en 1995 do Centro Europeo de Conservación da Natureza, ECNC, Tilburg (Holanda), e compoñente do seu Consello científico entre 1998 e 2005. Membro do Capítulo Español do Club de Roma desde 1999. Autor ou editor de varios libros e monografías especializados, ten publicados uns cento cincuenta traballos científicos en revistas 
especializadas e un centenar de artigos de divulgación científica. Desenvolveu numerosos proxectos aplicados de Ecoloxía por encargos ou concursos nacionais, estranxeiros ou internacionais. Entre outros premios, recibiu o Osborne, pola defensa da natureza, en 1975; o de Medio Ambiente sobre Estudos Temáticos, en 1984, polos seus traballos sobre a corrección da erosión; o do Ayuntamiento de Madrid, en 1986, pola teoría da información en Cartografía ecolóxica; e o Premio Nacional de Medio Ambiente, en 2000, polo súa investigación ecolóxica e sobre a conservación da natureza.

Álvaro Domingues. Xeógrafo, doutorado cunha tese sobre urbanismo pola Facultade de Letras da Universidade do Porto en Xeografía Humana, en 1994. Obtivo o Prémio Caixa Geral de Depósitos en 1996. É profesor da Facultade de Arquitectura da Universidade do Porto. Foi, ademais, profesor convidado da Universidade Federal do Rio de Janeiro e da de Granada. A súa actividade céntrase no urbanismo e nas políticas urbanas contemporáneas. Como investigador do CEF Arquitectura do Porto, desenvolveu unha actividade regular de investigación no ámbito de proxectos internacionais con España, Holanda, Brasil e Francia. Publicou Área metropolitana do Porto (Porto, Instituto de Xeografía da Facultade de Letras, 1992) e Estudo Sócio-Económico da Área Metropolitana do Porto (Porto, Quaternaire Portugal, 1993). Foi coordinador de A cultura em aç̧ão: impactos sociais e território (Porto, Afrontamento, 2003) e traduciu o libro Metapolis: acerca do futuro da cidade, de François Ascher (Oeiras, Celta, 1998). Publicou artigos en numerosas revistas.

Caroline Domingues. Ensina a civilización española na Université Blaise Pascal (Clermont-Ferrand). É doutora en español e comunicación. En 2005 publica Identité régionale et Médias. L'exemple de la Galice, libro en que analiza as relacións ambiguas entre medios de comunicación e identidade. Galicia e o tema da identidade sempre foron o fío condutor das súas investigacións. Algúns dos seus traballos son «Méditerranéisme versus Atlantisme ou la réponse galicienne au mouvement noucentiste», publicado no libro colectivo Esthétique et idéologie au $X X^{e}$ siècle; «L'usage de l'art dans la construction 
d'une identité galicienne au XX' siècle», en De l'usage de l'art en politique; ou «La Galice: une mémoire trahie», en La guerre d'Espagne en héritage: entre mémoire et oubli.

A paisaxe intégrase nun estudo máis profundo sobre a definición -en gran parte ideolóxica- da identidade galega, fundada nos alicerces dunha ou varias paisaxes ben identificadas, que labraría un ser galego diferente e único, en "Quand le Paysage se mêle d'identité», en La Galice (actas).

Pierre Donadieu. Agrónomo e xeógrafo, Pierre Donadieu é profesor titular na École Nationale Supérieure du Paysage (ENSP) de Versalles. En calidade de investigador asociado ao Institut National de la Recherche Agronomique, no seo da Unidade Mixta de Investigación en Ciencias da Acción e do Desenvolvemento de París-Grignon, dirixe o laboratorio de investigación da École Nationale Supérieure du Paysage (LAREP). É, ademais, responsable do Máster o proxecto da paisaxe: teorías e aproximacións, organizado conxuntamente coa Universidade de París I Panthéon-Sorbonne e o Institut des Sciencies et Industries du Vivant et de l'Environnement de París (AgroParisTech), e ten ao seu cargo a formación de doutoramento da ENSP no marco da escola doutoral de Agronomía, Alimentación, Bioloxía, Medio e Saúde (ABIES). Na actualidade, as súas liñas de investigación concirnen ás teorías, as prácticas e os oficios da paisaxe.

Julia Fernández de Caleya Blankemeyer. Doutora en Arquitectura pola Universidade da Coruña en 1995 e diplomada en Xardinaría e Paisaxe polo Instituto Politécnico Superior de Madrid en 1970. En 1974 realizou o Máster en planeamento urbano e rexional na University of Southern California (Los Ángeles). Realizou o Aulario da Coruña e as súas diversas ampliacións, o colexio público de Corrubedo, o colexio público e mais o polideportivo de Malpica e o proxecto de axardinamento do recheo do castelo da Pobra do Caramiñal. Entre a súa actividade docente destaca o seu labor como profesora de Xardinaría e Paisaxe na Escola Técnica Superior de Arquitectura, no Departamento de Urbanismo (1980-2009), e na Escola Técnica Superior de 
Enxeñeiros de Camiños, Canais e Portos da Coruña (1996-2009). Tamén foi profesora encargada do Grupo «Curso International ILAUD» en Venecia e San Marino International (Lavoratory of Architecture and Urban Design) Argot en 1996 e 1997, e codirectora e organizadora do primeiro Máster de arquitectura da paisaxe Juana de Vega, entre 2006 e 2008. Entre as súas publicacións destacan El diseño de los campos de golf, una aproximación paisajista, artigos en diferentes revistas especializadas e colaboracións co Centro de Arte Contemporánea sobre a paisaxe.

José Antonio Fernández de Rota y Monter. Catedrático de Antropoloxía Social na Universidade da Coruña, onde foi decano da Facultade de Humanidades. É académico correspondente da Real Academia Española de Ciencias Morales y Políticas e membro do Instituto Internacional Transcultura de París. O seu traballo de campo en zonas rurais de Galicia foi publicado nunha triloxía, Antropología de un viejo paisaje gallego, Gallegos ante un espejo. Imaginación antropológica en la Historia e Protagonistas de la Economía Básica. Estudou temas de identidade e nacionalismo en obras como Nacionalismo, cultura y tradición ou Nos lindeiros da galeguidade. Editor ou director de nove obras colectivas e de máis de cen publicacións nacionais e internacionais en revistas científicas ou capítulos de libros.

Jacobo García Álvarez. Profesor titular de Xeografía Humana na Universidad Carlos III de Madrid, onde ensina desde o ano 2003. Anteriormente foi alumno e profesor da Universidad Autónoma de Madrid, na que se licenciou e doutorou. Obtivo o Premio Extraordinario polo seu doutoramento 1999-2000 e o Premio de Investigación 2000 en Humanidades da Real Academia de Doctores. Concedéronselle diversas bolsas predoutorais e posdoutorais de investigación en España e no estranxeiro (Reino Unido, Estados Unidos, Países Baixos, Francia, Finlandia, Arxentina, Colombia...) e foi profesor invitado en varios centros estranxeiros, como a École des Hautes Études en Sciences Sociales de París, Université de Pau, University of Oulu, Universidade do Porto e a Universidad Autónoma Metropolitana de México. As súas investi- 
gacións centráronse na xeohistoria das divisións, ideoloxías e identidades territoriais, así como na historia das ideas xeográficas. Nos últimos anos estudou tamén a temática das paisaxes, lugares e políticas de memoria na España contemporánea. Entre os seus traballos principais figuran os libros Provincias, regiones y comunidades autónomas. La formación del mapa politico de España (2002) e Territorio y nacionalismo. La construcción geográfica de la identidad gallega (2003). Desde agosto de 2008 é presidente da Comisión de Historia da Xeografía da Unión Xeográfica Internacional.

Marcial Gondar Portasany. Catedrático de Antropoloxía Social da Universidade de Santiago de Compostela, patrón do Museo do Pobo Galego, membro da European Association of Social Anthropology e membro da Sección de Etnografía do Seminario de Estudos Galegos (CSIC). Traballa temas de identidade, antropoloxía política e antropoloxía aplicada, esta última con especial referencia ao tema da saúde mental. Entre as súas publicacións destacan: Parentesco, familia y matrimonio en la historia de Galicia e Crítica da razón galega. Entre o Nós-mesmos e o Nós-outros. Participou en seminarios de reflexión sobre a paisaxe como: Territorio, paisaxe e identidade (Museo de Pobo Galego, xaneiro 2007) ou Paseantes, viaxeiros e paisaxes (CGAC, outubro 2007).

Federico López Silvestre. Profesor doutor de Historia das Ideas Estéticas na Universidade de Santiago de Compostela desde 1998 e Premio extraordinario de doutoramento cunha tese dedicada á paisaxe. Entre as súas publicacións destacan os libros El paisaje virtual (2004), Os límites da paisaxe (2008) e A emerxencia da paisaxe (2009), e como editor, Nuevas visiones del paisaje (2006), Paseantes, viaxeiros e paisaxes (2007) e Estruturas na paisaxe (2009). Foi director de varios proxectos financiados sobre as paisaxes contemporáneas e, con María Luísa Sobrino, dirixe o Máster de arte, museoloxía e crítica contemporáneas da USC. Coordina a liña de traballo «A construción da paisaxe» do Centro Galego de Arte Contemporánea. Así mesmo codirixe con Javier Maderuelo e Joan Nogué a colección Paisaje y Teoría da Editorial Biblioteca Nueva (Madrid). Participou en congresos internacionais e fixo 
estadías de investigación en Portugal, Italia, Francia, Alemaña, Finlandia, Brasil, Chile, Arxentina ou a Polinesia.

Rafael Mata Olmo. Catedrático de Xeografía da Universidad Autónoma de Madrid, onde se formou, e presidente do Colegio Oficial de Geógrafos de España. Gran estudoso dos usos da terra e da cuestión agraria, publicou, entre outros, os libros: Atlas de los Paisajes de España, en 2003, e Los paisajes de Madrid: Naturaleza y medio rural, en 2000. Obtivo o Premio de Urbanismo da Comunidade de Madrid. Dirixiu numerosos proxectos de investigación financiados. Entre os seus moitos artigos en publicacións especializadas destacan achegas como «La Huerta de Murcia. Landscape guidelines for a peri-urban territory» para a revista Landscape Research, en 2004.

Raffaele Milani. Profesor de Estética na Università di Bologna, Departamento de Filosofía. Dirixiu un máster europeo sobre a paisaxe e é membro de comités científicos de institucións nacionais e internacionais. Impartiu cursos e conferencias en varias universidades de Europa, dos Estados Unidos e do Xapón. Participou tamén en numerosos congresos sobre cuestións de estética. Entre as súas obras lembramos Categorie estetiche (Parma, 1991), Il Pittoresco. L'evoluzione del gusto tra classico e romantico (Bari, 1996), Il fascino della paura. Linvenzione del gotico dal rococò al trash (Milán, 1998), L'arte del paesaggio (Boloña, 2001), Il paesaggio è un'avventura (Milán, 2005); xunto a Laura Falqui, L'atelier naturale. Cinema e giardini (Fiesole, 2008). Ademais editou varias coleccións de estudos e investigacións sobre a estética da paisaxe e a natureza.

Joan Nogué. Catedrático de Xeografía Humana da Universitat de Girona e director do Observatori del Paisatge de Catalunya (www.catpaisatge.net). Doutorouse na Universitat Autònoma de Barcelona e ampliou estudos na University of Wisconsin Madison (EE UU), baixo a dirección do profesor Yi-Fu Tuan. Foi tamén profesor visitante en varias universidades estranxeiras. 
A súa investigación céntrase en dúas grandes liñas: a historia do pensamento xeográfico e territorial, e a paisaxe desde a óptica dos estudos culturais. Publicou dez libros sobre ambos os dous temas e numerosos artigos en revistas internacionais de recoñecido prestixio. É codirector da colección Paisaje y Teoría, da editorial Biblioteca Nueva, e colaborador habitual do suplemento «Cultura's» de La Vanguardia. Os seus últimos libros son Las otras geografias, en 2006, en colaboración con Joan Romero, La construcción social del paisaje, en 2007, e El paisaje en la cultura contemporánea, en 2008.

Albino Prada Blanco. Profesor titular no Departamento de Economía Aplicada da Universidade de Vigo. Na actualidade é membro do Consello Galego de Estatística e do Consello da Cultura Galega, na Sección de Ciencia, Natureza e Sociedade. Ata o ano 2007 representou á Universidade de Vigo no Consello Económico e Social de Galicia, e foi decano da Facultade de Economía e Empresa desta universidade. Realizou informes e dirixiu asistencias técnicas para o Parlamento de Galicia e a Xunta de Galicia. Foi tamén investigador principal de proxectos que contaron con financiamento público do Ministerio de Educación, a Consellería de Educación ou a Fundación Caixa Galicia sobre economía dos recursos naturais (parques nacionais, Rede Natura 2000, biomasa enerxética, etc.) nos últimos anos. É autor dun manual sobre economía de Galicia editado primeiro en galego e posteriormente en castelán. Entre as súas publicacións máis recentes destaca Environmental economics and society.

Pablo Ramil Rego. Profesor titular de Botánica da Universidade de Santiago de Compostela e director do Instituto de Biodiversidade Agraria e Desenvolvemento Rural (IBADER). As liñas de investigación desenvolvidas inclúen dende estudos sobre a reconstrución do clima e os cambios dos ecosistemas terrestres no último ciclo glaciar-interglaciar, a traballos orientados á diagnose, valoración, planificación e xestión dos espazos naturais e os compoñentes da biodiversidade. É membro do Comité Español do Programa Home \& Biosfera e do Observatorio Galego da Biodiversidade. Publicou, entre outros 
libros: A lagoa de Cospeito (2006), Terras de pedra e auga (2005), Humedales de Galicia (2002), La evolución del paisaje en las montañas del entorno de los caminos jacobeos (1993).

Carlos Vales. Licenciado en Bioloxía pola Universidade de Santiago de Compostela e catedrático de Ciencias Naturais. $\mathrm{Na}$ actualidade dirixe o Centro de Extensión Universitaria e Divulgación Ambiental de Galicia. É membro da Comisión de Educación e Comunicación da Unión Internacional de Conservación da Natureza (UICN), así como da Sección de Ciencia, Natureza e Sociedade do Consello da Cultura Galega. Como experto en conservación da biodiversidade e divulgador ambiental, é autor de diversas e publicacións, entre as que se poden destacar As Fragas do Eume, O lobo, a extinción de especies e outros ensaios sobre conservación ou Forgoselo, espacio natural, e coordinador da edición de Os bosques atlánticos europeos, Baldaio, espacio natural protexido ou O Meio Natural Galego. Cuadernos do Seminario de Sargadelos. 



